UNIVERSIDADE DE SÃO PAULO

FACULDADE DE FILOSOFIA, LETRAS E CIÊNCIAS HUMANAS DEPARTAMENTO DE LETRAS CLÁSSICAS E VERNÁCULAS PROGRAMA DE PÓS-GRADUAÇÃO EM LETRAS CLÁSSICAS

WALDIR MOREIRA DE SOUSA JUNIOR

AS FENÍCIAS DE EURÍPIDES: ESTUDO E TRADUÇÃO

Versão Corrigida

SÃO PAULO 
UNIVERSIDADE DE SÃO PAULO

FACULDADE DE FILOSOFIA, LETRAS E CIÊNCIAS HUMANAS

DEPARTAMENTO DE LETRAS CLÁSSICAS E VERNÁCULAS

PROGRAMA DE PÓS-GRADUAÇÃO EM LETRAS CLÁSSICAS

\section{AS FENÍCIAS DE EURÍPIDES: ESTUDO E TRADUÇÃO}

Versão Corrigida

Waldir Moreira de Sousa Junior

Dissertação apresentada ao Programa De Pós-Graduação em Letras Clássicas Do Departamento de Letras Clássicas e Vernáculas da Faculdade de Filosofia, Letras e Ciências e Ciências Humanas da Universidade De São Paulo para a Obtenção do título de Mestre em Letras.

Orientadora: Profa. Adriane da Silva Duarte

SÃO PAULO 


\section{AGRADECIMENTOS}

À FAPESP, por financiar minha pesquisa de mestrado e de iniciação científica.

À Profa. Dra. Adriane da Silva Duarte, sob cuja rigorosa e atenciosa orientação consegui transformar meus pensamentos sobre Eurípides em uma dissertação de mestrado.

Aos meus professores de grego e latim que, de uma forma ou de outra, desde a graduação, conduziram-me até aqui: Adriano Machado Ribeiro, Adriano Scatolin, André Malta Campos, Breno Sebastiani, Christian Werner, Daniel Rossi Nunes, Giuliana Ragusa, Jaa Torrano, José Eduardo dos Santos Lohner, Marcelo Vieira Fernandes, Marcos Martinho dos Santos, Pablo Schwarz Frydman, Paula da Cunha Corrêa, Paulo Martins. Em especial, destaco Breno e Daniel, pelas valiosas críticas e sugestões quando do exame de qualificação, e Paula, pela oportunidade de participar do projeto MINIMUS.

Aos membros da banca de defesa, Flávio Ribeiro de Oliveira e, novamente, Daniel Rossi Nunes. Suas observações (e, mais do que isso, o diálogo) permitiram-me repensar o essencial e o dispensável na minha argumentação e tradução.

Aos colegas de Mestrado e Doutorado em Letras Clássicas e aos meus amigos de faculdade: Jorge Henrique, Renata Cazarini, Ricardo Neves, Roberto Denardi, Ubiratã Bueno.

À minha família: meus pais, Waldir e Mônica, a quem devo tudo, minha irmã, Isabela, meus avós, tios e primos - entres esses, destaco Valéria Framil e Pedro Dias Ribeiro, que tanto me ajudaram a me situar em São Paulo. 


\title{
RESUMO
}

O objeto de estudo desta dissertação é a tragédia As Fenícias de Eurípides. Mito e Ritual são os dois aspectos em que a peça será analisada na primeira parte deste trabalho, dividida em dois capítulos: o primeiro visa entender como o tragediógrafo fez uso da tradição mítica para construir o enredo da peça e como ele pode ter se valido de elementos de outros gêneros literários para construir novos significados dramáticos em sua obra; o segundo visa entender a dimensão religiosa da peça em seu aspecto ritualístico, ou seja, como determinados elementos textuais podem sugerir paralelos com sua ocasião de performance. Na segunda parte, apresenta-se a tradução integral da referida peça.

\begin{abstract}
This study presents Euripides' Phoenician Women as its subject under discussion. "Myth and Ritual" are the two aspects under which the play will be investigated in the first part: Chapter 1 seeks to understand in what manner Euripides displays the mythological stories into the production of the tragedy's plot: in this case, the multifarious literary traditions are analysed in conjuction with dramatic concerns; Chapter 2 seeks to understand the religious background of the play within its ritualistic context, that is, it will be suggested that the textual structure exposes dionisiac implications due to its poetic performance. In the second part, one reads the play wholly translated into portuguese.
\end{abstract}




\section{SUMÁRIO}

PROÊMIO

\section{PRIMEIRA PARTE:}

Capítulo I. Mito e tragédia em As Fenícias: uma releitura do mito trágico.

1.1 Introdução: As Fenícias e os espaço narrativo do coro 9

1.2 Construindo o mundo por meio dos mitos 22

1.2.1 A mentalidade mítica à época de Eurípides e o nome de Jocasta em As Fenícias $\quad 24$

1.3 As Fenícias e a mythopoiesis do Ciclo Tebano 38

Capítulo II. As Fenícias e o problema do culto religioso

2.1 Introdução e breve histórico sobre o estudo mito-ritual na tragédia: em busca de uma análise imanente ou transcendente?

2.2 Atos religiosos em As Fenícias

2.3 Problematik, Metodologia $\quad 74$

2.4 Mito e Ritual em As Fenícias $\quad 80$

$\begin{array}{ll}\text { CONSIDERACOEES FINAIS } & 95\end{array}$

\section{SEGUNDA PARTE:}

$\begin{array}{ll}\text { Tradução } & 97\end{array}$

REFERÊNCIA BIBLIOGRÁFICAS 


\section{PROÊMIO}

É comum entre os estudiosos salientar-se o caráter cívico-religioso do festival em que o gênero trágico se desenvolveu: nas chamadas Dionísias Urbanas, ou Grandes Dionísias, construía-se a identidade civil da pólis assim como se cultuava o deus Dioniso $^{l}$. Esses dois fatores, distintos, mas inalienavelmente complementares, formarão a premissa básica da argumentação deste trabalho. As Fenícias, peça que Eurípides encenou no fim do século $\mathrm{V}$ a.C e que apenas obteve o segundo lugar ${ }^{2}$, serão analisadas, em um primeiro momento, sob a perspectiva do mito e de sua função na ação dramática da peça como um todo. Em seguida, será questionado, conforme metodologia a ser explicada, em que medida a peça pode estar conectada com o contexto cultual do festival em que foi produzida. Neste sentido, a atividade coral ocupará papel preponderante nesta análise.

A elaboração do mito dos labdácidas (centrado na família de Édipo) adaptada para o gênero trágico em As Fenícias apresenta certas particularidades. Não apenas há "alterações", isto é, diversidade factual na história narrada quando comparada a outras fontes (e.g. Homero, Ésquilo, Sófocles), mas também certos traços textuais próprios de gêneros não dramáticos. Segundo Wright (2005, p.59), "novidade e experimentação míticas são características particularmente euripidianas", mas As Fenícias parecem trazer uma espécie de experimentação para além do mítico, no próprio cerne do "fazer" mitográfico. No primeiro capítulo, portanto, será argumentado que a narrativa mítica constitui uma forma de participação do coro no enredo do drama. Aparentemente desconectada do momento presente da ação dramática, a narrativa mítica, na verdade, figuraria como uma atualização do passado no presente, o que a faria, então, ser parte

\footnotetext{
${ }^{1}$ Sobre caráter religioso das Dionísias, ver Bierl (2009), Lesky (2003, p.74-81), Scullion (2002), Vernant (2008, p.161). Sobre caráter cívico das Dionísias, ver Goldhill (2000), Sourvinou-Inwood (2003, p. 71), e Kowalzig (2007, p.224).

${ }^{2} \mathrm{O}$ intervalo do tempo consensual entre estudiosos relativo à encenação da peça é 411-409 a.C, ver Kovacs (2002, p.203) e Medda (2006, p.77). Sobre a trilogia trágica em que estaria inserida, há duas hipóteses: 1)Hipsipile, As Fenícias e Antíope, ou 2)Enomau, Crisipo e As Fenícias. Ver estudo detalhado em Mastronarde (1994, p.11) e Amiech (2004, p.15). Informação sobre segundo lugar retirada da hipótese

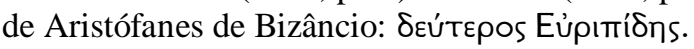


constitutiva da ação. Para se visualizar tal efeito, identificou-se um mecanismo operacional chamado aqui de "junção mito-ação".

O segundo capítulo abordará questões relacionadas à ocasião de performance do referido drama. Tragédia grega e festival dionisíaco são dois fenômenos culturais inextricáveis da Atenas do século V a.C. Como se sabe, as Dionísias e as Lenéias foram os dois principais eventos patrocinadores do gênero dramático, mas tudo que se sabe extradramaticamente a respeito de As Fenícias relaciona-se àquele primeiro festival. Assim, será explorado principalmente o aspecto religioso das Dionísias, a fim de se observar se é possível visualizar elementos cultuais ou ritualísticos na atividade coral da peça euripidiana.

De acordo com Sourvinou-Inwood (2003, pp.67-121), esse festival era eminentemente religioso $^{3}$ : precedido por um ritual conhecido como eio $\alpha \gamma \omega \gamma$ ń ớmò Tñs ĖoXápas ${ }^{4}$ (literalmente "introdução [sc. da estátua] a partir do altar": a estátua de Dioniso Eleutherios era transportada de seu santuário original, que ficava no teatro de Atenas, até outro templo de determinação incerta ${ }^{5}$, onde sacrifícios e hinos eram feitos em honra ao deus), As Dionísias se davam em três momentos principais: 1) a procissão (ou понти́, onde os participantes - cidadãos, metecos, e mulheres - carregavam falos, trazendo consigo um touro e numeroso gado para ser sacrificado no santuário de Dioniso, juntamente com pães e vinhos ${ }^{6}$ ); 2)a competição dramática (no teatro, uma estátua de Dioniso estava sempre presente durante as encenações, e o sacerdote de

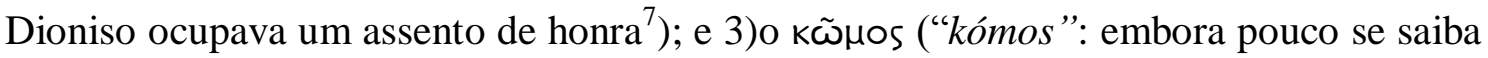
ao certo sobre essa etapa, ela é sempre relacionada ao uso de máscaras e ao consumo imoderado de $v$ inho ${ }^{8}$ ). Em suma, Sourvinou-Inwood (2003, p.73) interpreta o evento

\footnotetext{
${ }^{3}$ Goldhill $(1987,2000)$ analisa esse festival principalmente em seu aspecto cívico. Mesmo assim, ele conclui que "as Grandes Dionísias parecem-me essencialmente um evento dionisíaco" (1987, p.76).

${ }^{4}$ Toda citação de texto grego neste relatório será feita com caracteres gregos acompanhada de sua tradução para o português entre parênteses.

${ }^{5}$ Não há consenso entre estudiosos sobre o local exato do destino da estátua de Dioniso. Goldhill (1987, p.59) acredita ser um templo situado no caminho de Atenas para Eleuterai (cidade situada na fronteira Ática-Beócia); Sourvinou-Inwood (2003, p. 69), porém, argumenta que esse templo estaria situado na ágora de Atenas, próximo ao Altar dos Doze Deuses.

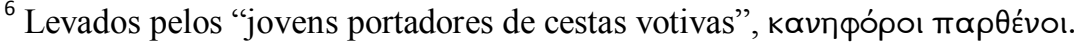

${ }^{7}$ Cf. Vernant (2008, p.158). A estátua do deus situava-se no centro da orquestra, num altar de pedra

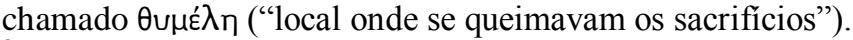

${ }^{8}$ O personagem lacedemônio Megilus das Leis (I, 637) de Platão, por exemplo, associa, de modo geral, as Dionísias à bebedeira.
} 
como um todo como um ritual de "recepção, de boas-vindas e de entretenimento do

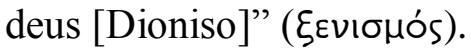

Desse modo, será objetivo do segundo capítulo desta pesquisa investigar como a tragédia, especificamente As Fenícias, pode se enquadrar, tal como os elementos listados acima, nesse aspecto religioso do festival em que se desenvolveu. Sócrates, no Banquete de Platão, associa o trabalho de Aristófanes essencialmente ao âmbito religioso (i.e a Dioniso): "Ninguém votará contrário a ti, Erixímaco [a respeito de discursarem alternadamente em louvor do Amor]. Pois nem eu discordaria, (...), nem Agatão e Pausânias, nem mesmo Aristófanes, cuja ocupação é toda concernente a Dioniso e a Afrodite" (negrito nosso). Seriam As Fenícias outrossim "concernentes a Dioniso"?

Por último, apresenta-se a tradução completa de As Fenícias, elaborada com fins acadêmicos. A edição do texto grego é aquela estabelecida por Mastronarde (1994).

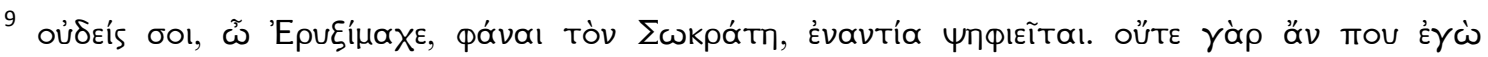

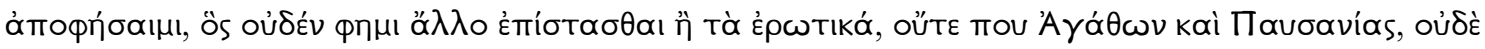

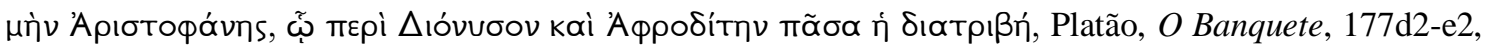
tradução do autor.
} 


\section{PRIMEIRA PARTE}

CAPÍTULO 1:

\section{MITO E TRAGÉDIA EM AS FENÍCIAS: UMA RELEITURA DO MITO TRÁGICO}

\subsection{Introdução: As Fenícias e o espaço narrativo do coro:}

As Fenícias de Eurípides situam o centro de sua ação dramática dentro de uma tradição mítica bastante conhecida entre os gregos, a saber, a história da família de Édipo. Herdeiro de uma tradição épica (e.g. Ciclo dos épicos tebanos Edipodia, Tebaida e Epigonoi ${ }^{10}$ ) e mesmo trágica sobre tal tema, Eurípides formula e adapta o mito dos labdácidas de uma maneira peculiar. Segundo nossa hipótese, a narrativa mítica presente nessa peça exerce papel para além da rememoração do passado, ela influi no próprio cerne dos acontecimentos da trama. Assim, para demonstrar como o uso do mito pode interferir na ação dramática, serão analisados neste capítulo principalmente as intervenções dramáticas de um grupo em específico, a saber, o coro.

Qual é a função do coro em As Fenícias? É importante notar-se desde o início que própria peça intitula-se a partir da constituição pátria do coro, composto por mulheres vindas da Fenícia, embora o ponto central de seu enredo seja a querela entre os filhos de Édipo. Ao longo dos acontecimentos que envolvem a casa real tebana, o tragediógrafo insere um grupo de pessoas cujo status político era tradicionalmente considerado marginal na sociedade grega: elas são mulheres e são estrangeiras. Além de se ocupar em comentar as ações e discursos dos outros personagens, o coro será o responsável por outra atividade que será objeto de estudo desta seção, a saber, a narrativa mítica.

Antes, porém, convém fazer uma introdução ao enredo e à divisão formal da peça, a fim de se observar como o coro se movimenta e relaciona entre as diversas partes constitutivas da ação dramática.

Como mencionado acima, a encenação desse drama não trouxe propriamente um tema novo para o teatro de Dioniso. A disputa entre Polinices e Etéocles pelo trono de

\footnotetext{
${ }^{10}$ Ver West (2013, p.2).
} 
Tebas já havia sido motivo dramático da peça Os Sete Contra Tebas (467 a.C) de Ésquilo. Ao contrário dessa peça, porém, o desenvolvimento da ação dramática de $A s$

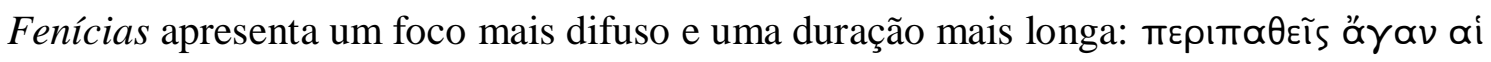

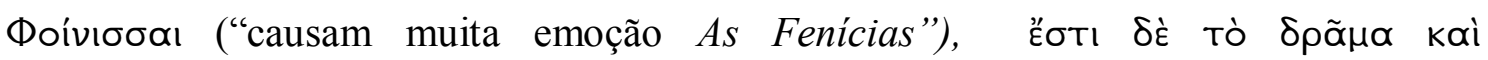

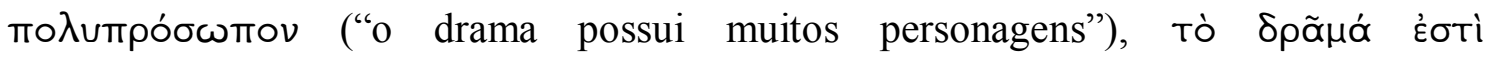

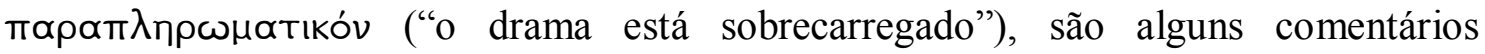
retirados de um escólio antigo da peça ${ }^{11}$. Tais comentários podem servir de prenúncio para o que mais tarde será chamado de "visão totalizadora do mito" - ressalte-se desde já o fator preponderante que o tragediógrafo tentou imprimir ao seu drama com a utilização do mito.

O argumento da peça envolve toda a família de Édipo e de sua esposa, Jocasta. A guerra entre Tebas e Argos perpetrada pelos filhos de Édipo, Etéocles e Polinices, é umas das mais marcantes da tradição grega. Pausânias (9.9.1), por exemplo, é da opinião de que ela teria sido a mais memorável já travada entre gregos contra gregos no que ele chama de "idade heroica". Na Ilíada (4.376-409), Agamenão também faz menção dessa guerra ao censurar Diomedes, filho de Tideu (um dos guerreiros que invadiu Tebas com Polinices).

Dividida em cinco episódios ${ }^{12}$ e contando com a participação de onze personagens mais o coro, As Fenícias abrangem a chegada do exército de Argos a Tebas, a preparação das duas cidades para a guerra, a guerra em si até o seu fim, a questão de Antígone referente à interdição do sepultamento do cadáver de Polinices, e o exílio de Édipo para a Ática. Além disso, questões adjacentes relacionadas à história de Tebas também são trazidas à tona, como o sacrifício de Meneceu, filho de Creonte. Não à toa que, das peças sobreviventes de Eurípides, As Fenícias sejam a mais longa.

A causa da guerra entre os irmãos é narrada no prólogo por Jocasta: após Édipo descobrir sua identidade e renunciar ao trono de Tebas, seus dois filhos, Etéocles e Polinices, fazem um acordo concernente ao comando da cidade: ambos revezariam o poder anualmente, sendo Etéocles o primeiro a governar. Este, contudo, passado um

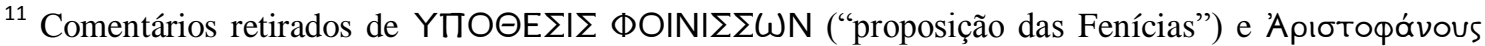

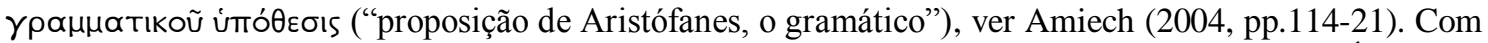
relação a Sófocles, há também muitos pontos de contato temáticos com Antígone (441 a.C), Édipo Rei (425 a.C) e Édipo em Colono (406 a.C).

${ }^{12}$ Outro quatro episódios, dependendo do critério adotado. Ver nota de rodapé número 15.
} 
ano, não cede o cetro a Polinices, que, em aliança com o rei de Argos, Adrasto, decide tomar à força o que é seu por direito.

Aos episódios caberá, seja pela encenação dos personagens, seja pela narração de mensageiros, mostrar os pormenores da contenda. Jocasta tenta, sem bom êxito, reconciliar seus filhos pelo diálogo. Etéocles discute com Creonte a melhor disposição para seu exército e ordena que o profeta Tirésias seja trazido à cidade para consulta. A profecia revelada diz que Tebas só vencerá se for sacrificado Meneceu, o jovem filho de Creonte. Este, descontente, planeja a fuga do filho, que, contrariando afinal seu pai, resolve entregar sua vida pela cidade. Iniciado o combate, ambos os lados sofrem muitas perdas, mas a guerra permanece inconclusa. Para finalizá-la, Etéocles e Polinices propõem um combate singular. Jocasta, ao saber disso, vai com Antígone ao campo de batalha para impedir a luta entre os irmãos, mas chega tarde demais: vendo os filhos à beira da morte, decide ela também tirar a própria vida. A guerra reinicia-se e Tebas sai vencedora. Creonte, o novo rei, proíbe o sepultamente de Polinices e exila Édipo. Antígone contesta a decisão de Creonte e decide enterrar, contra a lei, o corpo de seu irmão. Por fim, ela proclama seu autoexílio a fim de acompanhar seu pai à cidade de Colono, na Ática.

A estrutura completa da peça será delineada a seguir como estudo introdutório para a análise dos cantos corais feita nesta seção e nas subsequentes. O contexto em que o coro se manifesta é, assim, fornecido agora em forma de panorama. Por esse motivo, por ora as partes corais serão mencionadas sem muitos pormenores, pois serão discutidas com mais vagar ulteriormente. Afora os cinco episódios já mencionados, a peça contém o prólogo, quatro estásimos, e o êxodo:

Prólogo (1-201): contém o monólogo de Jocasta (1-87), e a theichoscopia (88201).

É comum as peças de Eurípides se abrirem com um monólogo (e.g. Alceste, Andrômaca, Helena, Orestes). O monólogo de Jocasta consiste principalmente em uma narração $a b$ ovo dos acontecimentos que levaram ao conflito entre os irmãos Etéocles e Polinices. Jocasta é representada por um ator que utiliza uma máscara de uma mulher velha, apresentando a cabeça raspada e trajando roupas escuras ${ }^{13}$. Este monólogo,

\footnotetext{
${ }^{13}$ É possível encontrar essas informações no texto da peça: assim Polinices descreve a figura de sua mãe no primeiro episódio: "vejo-te/ com a cabeça raspada, em atro manto/ vestida" (371-3).
} 
segundo Mastronarde (1994, p.139) tem o objetivo de predispor a audiência em dois pontos: contextualizar a história dos filhos de Édipo e mostrar o envolvimento de Jocasta no futuro agón (“disputa”) da peça.

A teichoscopia (literalmente "observação [feita a partir] das muralhas") consiste em um diálogo entre Antígone e seu preceptor, que não é nomeado. À maneira do que ocorre no canto III da Ilíada ${ }^{14}$, o preceptor descreve para sua pupila os principais guerreiros do exército inimigo. A autenticidade desta cena já foi muito questionada, mas estudos modernos tendem a considerá-la legítima ${ }^{15}$. O diálogo se passa sobre o telhado da skené $^{16}$ (edifício ao fundo do palco). A cena se caracteriza por ser uma amoibaion (diálogo lírico entre dois atores ou um ator e o coro) entre a voz masculina que fala em trímetros jâmbicos e a voz feminina que canta $^{17}$ numa miscelânea de ritmos.

Párodo (202-60): contém cinco estrofes onde o coro se apresenta e comenta a situação atual de Tebas. Apresenta uma característica que é marcante nas últimas peças de Eurípides, a saber, a presença de metros de tradição eólica ${ }^{18}$.

$1^{\circ}$ Episódio (261-637): pode ser dividido em duas partes, o diálogo entre Polinices e Jocasta (261-442), e o agón lógon (“disputa de discursos”) entre Polinices e Etéocles (443-637).

A primeira parte apresenta Polinices para a audiência. À Jocasta cabe entoar uma triste ária sobre sua atual situação (301-54). O centro dessa cena, porém, é a esticomitia (diálogo em que cada personagem profere um verso por vez) entre Polinices e Jocasta a respeito do exílio daquele (355-427). Na apresentação inicial de Polinices, predomina o trímetro jâmbico, assim como na parte de esticomitia. A ária de Jocasta apresenta uma combinação de ritmos, predominando os dócmios e jambos ${ }^{19}$.

O agón lógon entre os irmãos se dá em torno da discussão da legitimidade do poder de Tebas. À maneira sofística, cada um dos irmãos irá reclamar para si o direito e

\footnotetext{
${ }^{14}$ Ilíada (III, 161-244). Aqui, porém, é Helena que descreve os guerreiros inimigos a Príamo.

${ }^{15}$ Sobre autenticidade da Teichoscopia, ver Burgess (1988). Para resumo de toda a discussão, ver Mastronarde (1994, pp. 168-73) e Amiech (2004, pp. 260-3).

${ }^{16}$ Cf. Amiech (2004, p.233).

17 "O amoibaion caracterizado por uma voz masculina falando e uma voz feminina cantando é uma forma tipicamente euripidiana", cf. Mastronarde (1994, p.171).

${ }^{18}$ Cf. West (1982, pp.30-1), West (1982b, p.287). Ver divisão métrica completa em Mastronarde (1994, pp.211-2).

${ }^{19}$ Ver Mastronarde (1994, p.234-5).
} 
a justiça de governar a cidade. Esquematicamente, Mastronarde (1994, p.273) propõe a seguinte divisão: preliminares (446-68), debate tripartite de rhéseis (uma rhésis é qualquer discurso extenso feito em trímetros, ou, raramente em tetrâmetros, 469-587), discussão argumentativa em esticomitia/antílabe (588-624) e discursos de despedidas (625-37). O ritmo predominante é o trímetro jâmbico.

$1^{\circ}$ estásimo (638-89): contém apenas três estrofes. Estrofe e antístrofe retomam a história da fundação de Tebas, já mencionada por Jocasta, agora focada, porém, na morte que Cadmo causou ao dragão de Ares. O epodo contém uma invocação de caráter eminentemente apotropaico. Mastronarde (1994, p.329) observa que estrofe e antístrofe têm um "metro sem emoção" ("unemotional metre"), enquanto que no epodo o ritmo se torna mais agitado.

$2^{\circ}$ episódio (690-783): Etéocles e Creonte deliberam acerca da batalha que está por vir. Diálogo entre os dois se dá em grande parte em esticomitia.

$2^{\circ}$ estásimo (784-833): Estrofe e antístrofe fornecem uma interpretação divina acerca da batalha entre os irmãos que agora é iminente. Epodo retoma narrativa mítica acerca dos primórdios da cidade de Tebas. Mastronarde (1994, p.373) ressalta a forte dicção esquiliana da passagem, e a tonalidade tardo-euripidiana do grande uso de epítetos polissilábicos. A tríade é quase inteira construída em dátilos ${ }^{20}$.

$3^{\circ}$ episódio (834-1018): Tirésias entra em cena e profetiza a salvação de Tebas: a cidade deve sacrificar o filho de Creonte, Meneceu. A revelação do oráculo é feita em esticomitia entre o profeta e Creonte. Outra esticomitia/antílabe se dá entre este e seu filho. O episódio se fecha com a rhésis patriótica de Meneceu, que decide pelo suicídio/auto-sacrifício.

$3^{\text {o }}$ estásimo (1019-66): apresenta apenas estrofe e antístrofe. Estrofe faz narração da chegada da Esfinge a Tebas, antístrofe narra a chegada de Édipo.

$4^{\text {o }}$ episódio (1067-1283): a cena é marcada por duas longas rhéseis (1090-1199, 1217-1233) de uma nova personagem, o mensageiro, identificado como escudeiro ( $\pi \alpha \varrho \alpha \sigma \pi \iota \sigma \tau \dot{\varsigma}, 1073)$ de Etéocles. Relata-se aqui o que se sucedeu ao que foi prenunciado no primeiro episódio da peça: a luta dos irmãos. O episódio ainda traz uma

\footnotetext{
${ }^{20}$ Análise métrica completa em Mastronarde (1994, pp.375-6).
} 
esticomitia/antílabe (1272-1279) entre Jocasta e Antígone, que decidem ir ao campo de batalha em favor dos filhos/irmãos que ainda vivem.

$4^{\circ}$ estásimo (1284-1307): formado por uma estrofe e antístrofe de apenas doze versos cada, este último estásimo segue uma tendência do gênero de se fazer mais curto por ser o último, uma vez que a ação se direciona ao seu clímax ${ }^{21}$. O conteúdo basicamente consiste em lamentações a respeito da situação de Tebas.

$5^{\mathrm{o}}$ episódio (1308-1479 22 : Creonte e o coro antecedem a entrada do segundo mensageiro em um diálogo a respeito do sacrifício de Meneceu e da saída de Jocasta e Antígone ao campo de batalha (esticomitia 1335-1339). A narração do mensageiro pode ser dividida em duas rhéseis (1356-1424, 1427-1479): a primeira narra o desfecho do duelo entre os irmãos, a segunda o desfecho da ação de Jocasta e a conclusão da guerra.

Ponte Coral (1480-1484): serve de transição entre a rhésis narrativa do mensageiro e a parte lírica de Antígone. Basicamente o coro entoa lamentações quando da chegada dos cadáveres de Etéocles, Polinices e Jocasta em cena ${ }^{23}$.

Ária de Antígone (1485-1538) e Dueto de Antígone e Édipo (1539-1581): para Dihle (1981, p.106), toda essa parte da peça seria espúria: As Fenícias terminariam com a ponte coral descrita acima. As edições mais recentes da peça, porém, reconhecem a legitimidade desses versos ${ }^{24}$. De acordo com Mastronarde (1994, p.553), a ária de Antígone pode ser assim dividida: “autoapresentação ('self-presentation') do lamentador", "anúncio e apresentação da tragédia" e "retórica aporética da dor". No Dueto Édipo-Antígone, esta anuncia a seu pai em canto lírico o que o segundo mensageiro narrou na sua segunda rhésis.

Êxodo (1582-1709): tem por centro o embate entre Creonte e Antígone acerca do sepultamento de Polinices (esticomitia: 1646-82 $2^{25}$ ). Também em diálogo

\footnotetext{
${ }^{21}$ Cf. Mastronarde (1994, p.504) e Amiech (2004, p.514).

${ }^{22}$ Amiech (2004, p.518) prefere nomear toda a parte que vai do verso 1308 ao fim da peça de "êxodo". Seu argumento para isso é a divisão aristotélica da tragédia ("o êxodo é aquela parte completa da tragédia depois da qual não há um canto coral”, Poética, 1452b, tradução do autor). Mastronarde (1994, p.511), porém, entende a ária que seguirá esta cena como equivalente a um estásimo, por isso a designação desta parte de "quinto episódio". Para fins didáticos, preferiu-se aqui seguir a divisão de Mastronarde. Lamari (2010, p.110) adota a mesma divisão.

${ }^{23}$ Cf. Mastronarde (1994, p.533). Amiech (2004, p.547) observa que a exposição de cadáver no palco era algo comum no teatro grego. Ela cita como caso semelhante Os Sete Contra Tebas (846-848). Ver Deforge (1997, p.83).

${ }^{24}$ Cf. Kovacs (2002), Amiech (2004) e Medda (2006).

${ }^{25}$ Amiech (2004, p.567) chama essa cena de "a altercação de Creonte com Édipo e Antígone".
} 
esticomítico (1683-706), Antígone e Édipo ainda lamentam o desfecho dos acontecimentos e aquela comunica ao pai decisão de acompanhá-lo ao exílio em Colono.

Remate lírico e spuria (1710-66): segundo Mastronarde (1944, p.627), “tematicamente, a peça se completa no verso 1709". Aqui, retornando aos metros líricos, Antígone, Édipo e o coro cantam seus últimos versos a partir da skené26. Antígone e Édipo se prepara para partir e o coro encerra a peça invocando a deusa Vitória.

Eis, resumidamente, do que se tratam As Fenícias. Em meio a essa profusão de acontecimentos, um grupo de mulheres estrangeiras manifesta-se intensamente, colocando-se em contato direto com os protagonistas da ação, personagens da alta prosápia tebana. Acima foi indagada a função do coro na trama da peça. Para compreensão correta desse ponto, porém, é necessário se indagar, antes, quem exatamente são essas mulheres e com que autoridade elas participam de perto de todos esses eventos.

Em seu estudo dedicado à arte euripidiana, Mastronarde (2010) dedica um capítulo a questões relativas ao coro trágico. Um dos pontos trazido à tona por ele é um trecho da Poética de Aristóteles que estabelece uma comparação entre o coro de Eurípides e o de Sófocles. Segundo o filósofo grego, “o coro deve ser considerado um entre os personagens, parte do todo, e deve tomar parte na ação dramática não à maneira de Eurípides, mas à maneira de Sófocles ${ }^{27}$ ". O verbo grego utilizado por Aristóteles é sunagonizesthai, literalmente "tomar parte na disputa", ou, especificamente com relação à tragédia, "tomar parte na ação".

Para Mastronarde (2010, p.147-150), são dois os traços do coro euripidiano que poderiam explicar tal comentário: "a não imediata, ou indireta conexão entre o episódio e os estásimos" e a presença da narrativa mítica que causaria um distanciamento da ação dramática. Assim, para o autor, o coro de Eurípides tende a ser, não sempre, mas muitas vezes, "menos imediatamente engajado emocionalmente na ação". A intenção deste capítulo, todavia, é mostrar que a peça As Fenícias não se encaixa nesse conjunto, principalmente devido à constituição peculiar do coro. Em outros termos, quer-se

\footnotetext{
${ }^{26}$ Cf. Amiech (2004, p.596).

${ }^{27}$ Poética, 18, 1456a25-32.
} 
mostrar que a narrativa mítica constitui-se, neste caso em específico, uma forma de participação do coro no enredo do drama. Aparentemente desconectada do momento presente da ação dramática, na verdade, ela figurará, como será argumentado a seguir, como uma atualização do passado no presente. Neste sentido, isso equivale dizer que a própria narrativa mítica estaria tomando parte da ação, ou seja, ela, de fato, nas palavras de Aristóteles, sunagonizesthai.

Em primeiro lugar, então, é necessário retornar-se à questão da identidade coral. Conforme elucidará posteriormente a concatenação dos argumentos, ela confere à narrativa mítica inserção fatual na ação dramática. Ora, sabe-se que o coro é formado por mulheres fenícias. A presença dessas mulheres em Tebas, por acaso ou por acinte, cinco gerações após a chegada de Cadmo, ainda reverbera os atos funestos da época da fundação da cidade $^{28}$. Em outras palavras, a fermentação da guerra de Tebas que absorve os espíritos alvoroçados de Polinices e Etéocles é um fruto tardio, pode-se dizer, da vinda de Cadmo da fenícia à Beócia, e o coro será o representante desse passado, ao mesmo tempo que esse passado legitimará as suas manifestações na peça.

De índole um tanto receosa e com uma linguagem bastante artificiosa, o coro se pronuncia mais expressivamente em cinco ocasiões, considerando-se as partes designadas a ele segundo o gênero, no párodo e em quatro estásimos. Relanços de participação também são vistos nos episódios, seja em admoestações, seja defendendo a sã moral da justiça de Polinices e repreendendo os excessos da esperteza palavrosa de Etéocles. No párodo, o coro revela sua origem e o motivo de sua estadia na Grécia, e rapidamente relata a situação belicosa em que se encontra Tebas. Nos estásimos, porém, percebemos que ele exerce sua principal atividade na peça, a saber, a narrativa mítica.

Segundo Rutherford (2007, p.11), é possível encontrar cantos corais narrativos na maioria das tragédias sobreviventes, mas é no Eurípides tardio que essa característica se manifesta com maior expansão. As Fenícias, encenada aproximadamente em 410 a.C, ou seja, uma das últimas peças de Eurípides, representam o cume de produção deste teor. De fato, dos seus quatro estásimos, os três primeiros versam sobre a história de Tebas, cobrindo um espaço temporal, de todo em todo, que vai de Cadmo a Édipo.

\footnotetext{
${ }^{28}$ Cadmo é considerado o fundador da cidade de Tebas. Depois dele, reinaram na cidade, todos descendentes seus, Polidoro, Lábdaco, Laio, Édipo, Polinices. Todas essas informações são resumidamente expostas no prólogo da peça, no monólogo de Jocasta (5-56). Ver genealogia completa na página 19 desta dissertação.
} 
Rutherford (2007, p.11), a propósito, entrevê aí a intenção do poeta de se narrar toda a história da mitologia tebana. Esta dissertação, por sua vez, sem discordar deste autor, vê a construção da narrativa mítica coral em As Fenícias como um suporte para a ação dramática: os fatos do passado de Tebas evocados pelo coro funcionam como um padrão factual dos acontecimentos presentes do drama, e o coro pode expor tais fatos com propriedade porque conviveu com a família real fenícia, consanguínea a Cadmo, e portanto, a Édipo.

A origem do coro está bem demarcada na peça de Eurípides. Principalmente no párodo (202-260) encontram-se informações crucias a esse respeito, que podem ser listadas do seguinte modo $^{29}$ :

1)Mulheres vindas da Fenícia, da cidade de Tiro (202-204);

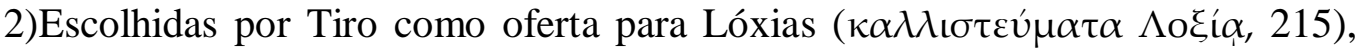
foram enviadas para Tebas ( $\left.\pi \varepsilon \mu \phi \theta \varepsilon \tilde{\imath} \sigma^{\prime} \dot{\varepsilon} v \theta \alpha \dot{\alpha} \delta \varepsilon, 219\right)$;

3)Partirão para o monte Parnaso (206-7), para banho ritual com águas de

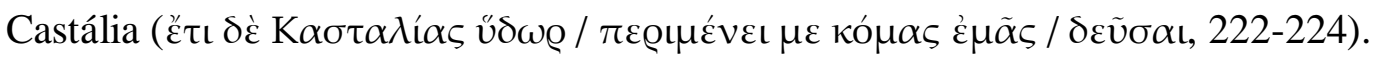

No primeiro episódio, esclarece-se que o motivo de essas mulheres terem sido enviadas a Grécia como “ofertas para Lóxias” se deve a um caso de guerra em sua pátria natal $^{30}$. Neste ponto já se vislumbra uma relação entre a família real de Tebas e a de

\footnotetext{
${ }^{29}$ Para além do párodo, é possível inferir duas informações de ordem diversa: uma relacionada à indumentária de tais mulheres, outra à linguagem. No primeiro episódio (278-9), Polinices, antes de

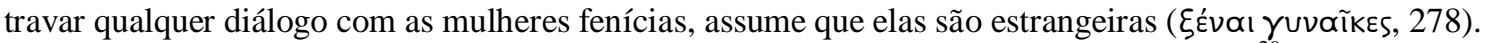
Estudiosos inferiram daí, portanto, que o motivo disso seria os trajes que elas vestiam ${ }^{29}$. Em segundo lugar, no mesmo episódio, Jocasta se refere a um "rumor fenício" que ela teria ouvido próximo ao palácio

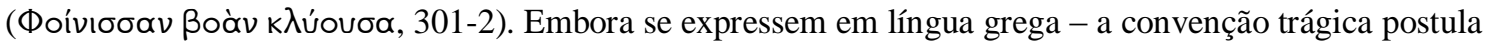
que os coros se expressem em um falar ático corriqueiro (cf. Mastronarde (1994, p.237) -, supõe-se que os atores interpretando as fenícias, então, apresentassem um sotaque fenício.

${ }^{30}$ Existe uma discussão a respeito do estatuto político do coro: seriam essas fenícias mulheres livres ou prisioneiras de guerra? A apresentação que elas fazem de si mesmas para Polinices tem gerado algumas controvérsias entre os estudiosos. O debate acima mencionado originou-se por causa da ambivalência

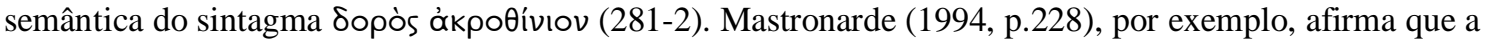
tradução "a melhor oferenda do espólio de guerra" só poderia ser feita se os versos estivessem fora de contexto. Para ele, a melhor tradução seria "choicest offerings in thanks for victory of war", porque a audiência já sabia que o coro era formado por mulheres livres de Tiro (cf. v. 214). Craik (1988, p.183), contudo, afirma que o termo ớkpotíviov traz o significado de "cativas de guerra", e, assim como ela, Medda (2006, p.149) prefere traduzir por "primizia da un bottino di guerra", donde se deve concluir que essas mulheres são prisioneiras de guerra. Kovacs (2002, p.239), por sua vez, traduz o sintagma por "em agradecimento por vitória em guerra", e esclarece que elas não eram "escravas capturadas em guerra, mas mulheres livres servindo Apolo (...) por alguma benção que o deus teria dado a Tiro".
} 
Tiro, pois o coro menciona Agenor, o pai de Cadmo, fundador de Tebas, ao mesmo tempo que revela que é Etéocles, o governante dessa cidade, o incumbido de enviá-las ao "altar de Lóxias" (280-285):

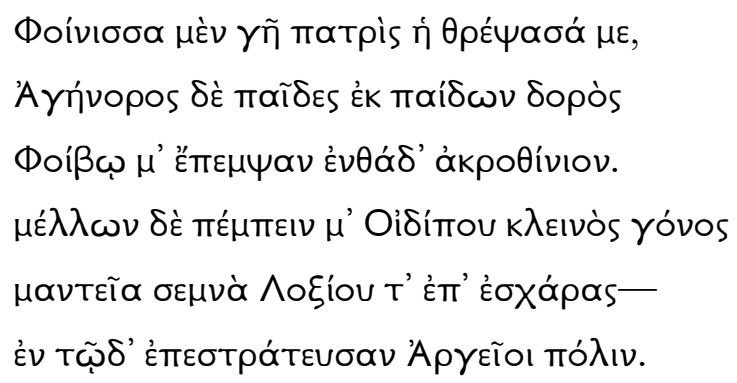

A terra fenícia foi a pátria que me criou,

E os filhos dos filhos de Agenor de guerra Me enviaram a Febo como primícias.

Ínclito filho de Édipo estava para me enviar Ao sacro oráculo e ao altar de Lóxias, Mas então os Argivos vieram atacar a cidade.

Mais importante, contudo, é observar a relação do coro com a família real de Tiro. Poucos versos adiante, nota-se que o coro traça uma linha direta de parentesco entre os filhos tebanos de Agenor (e.g. Cadmo e descendência) e os seus senhores fenícios. A autoridade com que o coro, ulteriormente, começa a relatar fatos da história de Tebas vem, portanto, do contato com pessoas que são da mesma linhagem dos reis de Tebas. Os versos são (291-2):

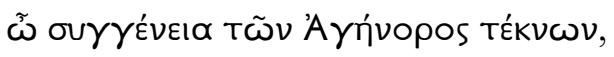

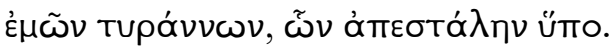

Ó parente dos filhos de Agenor Tiranos meus que cá me enviaram

É curioso que o coro ressalte a progenitura de Édipo e seus filhos a Agenor, não a Cadmo (cf. 219). Em As Bacantes (1305), a versão do mito da fundação de Tebas 
utilizada por Eurípides diz que Cadmo não teve filhos homens. Aqui, porém, sabe-se, pelo prólogo (8), que Cadmo gerou Polidoro, o bisavô de Édipo. Inversamente, ao longo de toda a peça a identidade tebana se construirá a partir da figura de $\mathrm{Cadmo}^{31}$. Para efeito de síntese, é possível se traçar a seguinte genealogia a partir do monólogo de Jocasta $^{32}(5-54)$ :

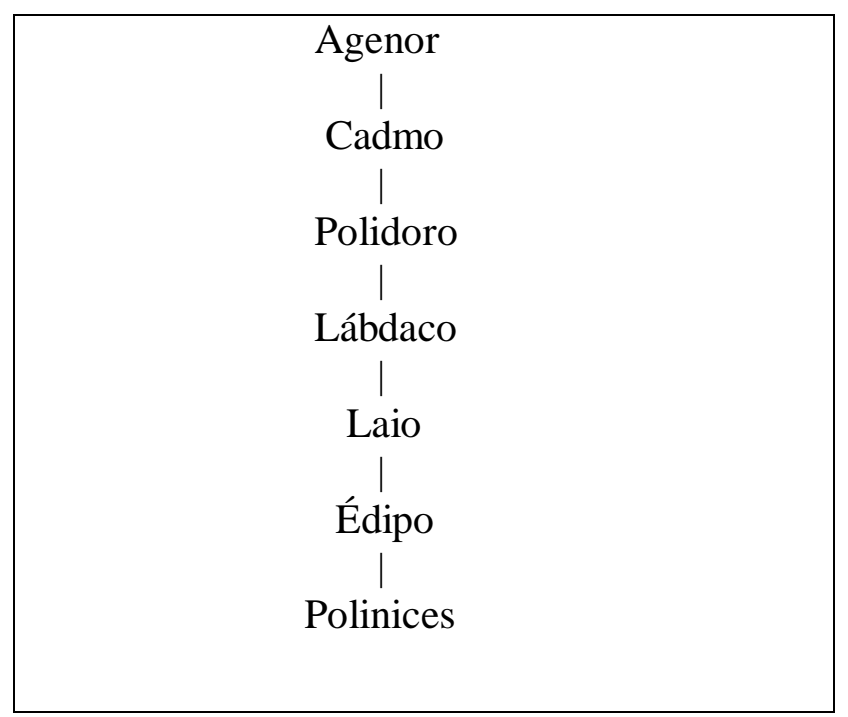

Claro está que o coro ressalta a consanguinidade entre a ascendência de seus senhores (de Tiro) e aquela dos filhos de Cadmo, então senhores de Tebas. Outra figura emblemática a reforçar tal ligação será Io. As mulheres fenícias cantam no párodo:

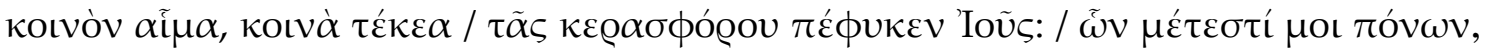
(“comum é o sangue, comum / a cria gerada da cornífera Io, / cujas dores me são presentes", 247-9). Io ainda aparecerá de novo duas vezes na peça, no $1^{\circ}$ e no $2^{\circ}$

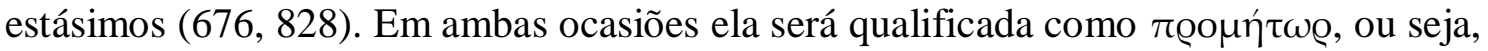
a "primeira mãe" de uma estirpe. Mas qual a relação de Io com o povo de Tebas e com as mulheres fenícias do coro?

No epodo do $1^{\circ}$ estásimo, Io é mencionada como mãe de Épafo (676-9), e, no epodo do $2^{\circ}$ estásimo, diz-se que Io gerou os reis dos cadmeus (829). Embora a peça não forneça nominalmente a descendência de Épafo, o coro informa que os filhos de

\footnotetext{
${ }^{31}$ Ver, por exemplo, monólogo de Jocasta (5), primeiro estásimo (638-689), que conta a história da vinda Cadmo à Beócia, e o gentílico cadmeu frequentemente usado pelo coro $(809,1019$, etc.).

${ }^{32}$ Exatamente igual é genealogia apresentada por Heródoto para os filhos de Agenor (4.147.4; 5.59).
} 
Épafo fundaram Tebas (682). De maneira geral, as fontes ${ }^{33}$ não entram em acordo a respeito da genealogia de Io, mas, segundo Pseudo-Apolodoro (Biblioteca, 2.1), é possível traçar o seguinte quadro:

\begin{tabular}{|c|}
\hline Io - Zeus \\
Épafo - Mênfis \\
$\mid$ \\
Líbia - Posído \\
$\mid$ \\
Agenor \\
\hline
\end{tabular}

A identidade do coro, portanto, constrói-se a partir de dados históricos (ou mitológicos) que permitem aproximar o coro à cidade de Tebas. A constituição exótica do coro não é algo fortuito, e a presença de mulheres fenícias naquele determinado momento em Tebas não é algo acidental. Os acontecimentos do passado ainda trazem consequências para o desenvolvimento dos acontecimentos do presente da cidade. Assim, o coro tem autoridade para rememorar o mítico e atualizá-lo no momento da contenda entre Etéocles e Polinices. Nas palavras de Arthur (1977, p.166), "as mulheres fenícias, então, em virtude de sua origem, são representantes da pré-história de Tebas, ou seja, de seu passado legendário".

Dentro da perspectiva cronológica da ação dramática, note-se que o coro representa igualmente um tempo sem paz e sem unidade entre os filhos de Tebas. Neste sentido, Foley (2003, p.21) ressalta a autoridade que coros femininos e estrangeiros têm em relação à memória cultural, especialmente em forma de mito:

\footnotetext{
${ }^{33}$ A ascendência de Agenor, por exemplo, é construída de maneira diversa por Pausânias (2.16.1). Amiech (2004, p.391) afirma que Épafo é pai de Agenor, não avô, como diz Pseudo-Apolodoro.
} 
Coros femininos (ou estrangeiros) parecem ter o mesmo grau de acesso à memória cultural oficial, especialmente na forma de mito, assim como a sua contraparte masculina, mesmo se eles às vezes fazem lembrar à audiência como eles adquiriram seu conhecimento (em casa, no tear, por histórias). (...) Embora os coros sejam geralmente de uma camada social mais baixa do que os personagens, estilisticamente, linguisticamente, religiosamente, performativamente eles podem ocupar um plano mais elevado devido à sua linguagem, aos seus temas, ao seu canto e sua dança.

Assim, no caso de As Fenícias, a relação do coro com a cidade de Tebas é trazida à tona novamente no $2^{\circ}$ estásimos, quando o coro menciona que conhecia a história dos Semeados, i.e., dos tebanos nascidos dos dentes do dragão de Ares

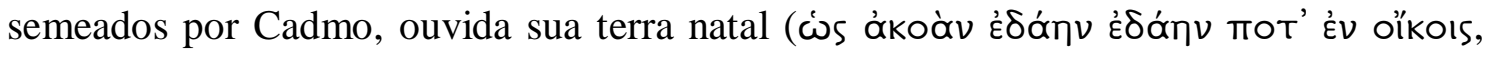
“como então aprendi em casa por bárbaro rumor”, 819).

Estabelecida sua autoridade cultural por meio de sua identidade, as informações fornecidas pelo coro a respeito do passado podem ser interpretadas em paralelo com os acontecimentos do presente da ação dramática. Na antístrofe do $1^{\circ}$ estásimo (657-675), o coro informa que Tebas é fruto de dois derramamentos de sangue: o primeiro, o de uma criatura pertencente a Ares, o deus comumente associado à guerra (epítetos de Ares

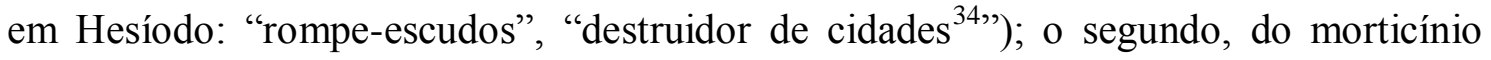
fratricida dos guerreiros nascidos da terra e dos dentes do dragão de Ares. Como será visto na seção 1.3, esses fatos têm ligação direta com a guerra entre Polinices e Etéocles. O banho de sangue ocorrido quando da fundação da cidade ( aímatos $\delta$ '

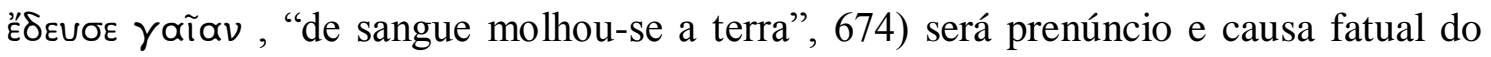
banho de sangue causado pelos filhos de Édipo.

A identidade do coro, portanto, serve para possibilitar que se tracem e evoquem paralelos mitológicos entre ele e os fundadores de Tebas. Como dito anteriormente, o papel do coro é predominantemente narrativo. A narrativa mítica coral, portanto, participa da ação atualizando o passado de Tebas no seu presente. A seção 1.3 mostrará os elementos textuais que tornam esse mecanismo possível. Por ora, pode-se ver, quantitativamente, a ênfase conferida à atividade narrativa coral pelo tragediógrafo por meio do seguinte esquema:

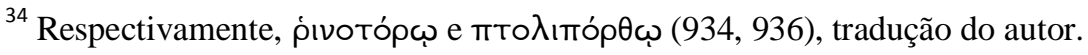


-1º estásimo (638-689): história da chegada de Cadmo a Tebas (638-648), do nascimento de Dioniso (649-656), e do dragão de Ares morto por Cadmo (bem como o nascimento dos “semeados", 657-675);

-2º estásimo (784-833): rememoração rápida acerca dos dentes do dragão, das núpcias de Harmonia e da construção das muralhas de Tebas feita por Anfião (818$833)$;

-3º estásimo (1018-1066): história da chegada da Esfinge à Tebas (1018-1042), história de Édipo (chegada a Tebas, incesto, maldição nos filhos, 1043-59).

Na próxima seção, este estudo suspenderá a linha sua de argumentação para traçar linhas teóricas sobre a questão do mito em si. Se Eurípides insistiu tanto na narrativa mítica em As Fenícias, é preciso compreender, conditio sine qua non, como o fenômeno cultural do mito em sua época se lhe apresentava e que condições tinha o poeta para manejá-lo em sua obra.

1.2 Construindo o mundo por meio dos mitos:

A peça As Fenícias, como visto acima, está circunscrita ao plano mítico do Ciclo Tebano. O objetivo desta seção, portanto, será analisar de que forma Eurípides trabalhou tal tradição mítica, servindo-se dela e remodelando-a, e, a partir daí, investigar quais as novidades propostas pelo poeta e quais os débitos do tragediógrafo para com a mentalidade mítica de sua época.

O esboço da atividade coral feito na seção precedente confirma o que Mastronarde (2010, p.124) escreve a respeito da peça em questão, classificando-a como “a mais elaborada evocação de eventos do passado". A narrativa mítica, porém, nesta peça, não é exclusividade do coro. Pelo menos em outras três situações, personagens também se ocupam em relatar fatos do passado: tal é o caso de Jocasta no prólogo (483, ou seja, 90\% de seu monólogo), Tirésias no terceiro episódio (867-877) e Édipo no 
êxodo (1595-1614). No total, é possível serem contabilizados 108 versos narrativos dos personagens e 119 versos do coro.

Para fazer com que as informações mítico-históricas sobre Tebas em sua peça tivessem valor dramático, como se postula aqui, deve-se notar que Eurípides herdara, a seu tempo, uma vasta tradição versando sobre o mesmo tema e, principalmente, uma nova concepção teórica que analisava e repensava o mito de forma inédita. Como ponto de partida, portanto, dois conceitos preliminares para o desenvolvimento argumentativo desta seção serão neste momento, elucidados, a saber, "mito" e "megatexto".

Por mito, tome-se a definição mais corrente do termo, qual seja, "uma história tradicional com implicações sociais que, dentro de uma estrutura de tempo transcendente, põe em cena personagens com características sobrenaturais e, portanto, fabulosas ${ }^{35}$ ". À vista disso, o gênero trágico que, embora tivesse como matéria prima os mitos, diferenciava-se deste por se definir intrinsecamente como uma criação literária deliberada, ao invés de ser tradicional. Parafraseando Calame (1972, p.119), tem-se, portanto, o mito oposto a um processo consciente de elaboração ${ }^{36}$.

Ora, esse processo consciente, i.e., o gênero trágico, seria então a tomada de consciência do modus operandi do mito, e o poeta teria a liberdade de inserir suas próprias “invenções literárias ${ }^{37}$ ". Desse modo, se Homero e Hesíodo foram os responsáveis por codificar os mitos gregos, esses foram reinterpretados pela tragédia ${ }^{38}$.

Em seguida, seja abordado o conceito de "megatexto", que será o ponto de partida para a futura interpretação a respeito do significado das alterações que Eurípides realizou no "mito recebido" dos labdácidas. De acordo com Lamari (2010, p.17):

Ele [Eurípides] inclui em As Fenícias uma vasta quantia de material mítico, fazendo da peça um "megatexto" mítico de Tebas por si mesma. Pela primeira vez no corpus dramático sobre Tebas, relatos sobre a pré-história tebana, o parricídio de Laio, a exposição de Édipo, a

\footnotetext{
${ }^{35}$ Calame (2009, p.1).

${ }^{36} \mathrm{Na}$ verdade, o estudo de Calame neste ponto não trata propriamente da tragédia, mas acreditamos que a transposição de gêneros neste caso é válida.

${ }^{37}$ Essa ideia, na verdade, já se encontra expressa desde Aristóteles (Poética, 1453b25): aủtòv סè

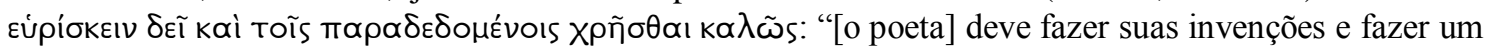
uso artístico dos [mitos] recebidos" (tradução do autor).

${ }^{38}$ Cf. Kirk (1970, p.247 ss.)
} 
maldição de Édipo, a luta entre Polinices e Etéocles, a expedição contra Tebas, o duelo fratricida entre Etéocles e Polinices, o suicídio de Jocasta, o casamento de Antígone e Hemon, o enterro de Polinices, assim como o exílio de Édipo são narrados/dramaticamente apresentados numa única peça. Eurípides aspira criar um panorama de Tebas, no qual uma quantidade abundante de informação mítica fica à disposição da audiência.

"Megatexto", portanto, refere-se a toda uma "quantidade abundante de informação mítica" disposta em um texto, seja de qual gênero for. Na verdade, esse termo, conforme explica a própria Lamari (2010, p.24), "fora cunhado por Segal (1986) e corresponde a textos (escritos ou orais) que encerram uma tradição mítica". As Fenícias, portanto, tornam-se um "megatexto" do gênero trágico e, embora o centro de sua ação seja especificamente o embate entre Etéocles e Polinices, a peça, por meio de analepses (história de Cadmo a Édipo) e prolepses (história de Antígone e do exílio de Édipo) narrativas (míticas), ultrapassa a fronteira do drama (mimesis).

Certo, todas as tragédias apresentam a mistura de mimesis e diegesis, bastando para isso notar-se a presença do discurso narrativo dos mensageiros (diegesis por excelência). Entretanto, o desenvolvimento textual de As Fenícias, conforme se argumentará adiante, parece ter pontos de intersecção com outro gênero, a saber, a mitografia. Neste sentido, um estudo de caso (i.e. o do nome da mãe Édipo) servirá como eixo argumentativo deste tópico. Se mitografia e tragédia confluem nessa peça, então é possível buscar algum significado, político ou religioso, por trás das alterações que Eurípides realiza no plano mítico de As Fenícias.

1.2.1. A mentalidade mítica à época de Eurípides e o nome de Jocasta em As Fenícias.

De certa forma, o estudo de caso que se propôs acima já foi examinado por outros autores. March (1987), Mastronarde (1994) e Lamari (2010), por exemplo, embora não se ocupem dessa questão demoradamente, foram unânimes em declarar que o motivo dessas mudanças reside unicamente em questões dramáticas. A colocação de Lamari (2010, p.135), especificamente, resume bem essa posição: “ao sistematicamente 
criar, e mesmo introduzir, inconsistência [no mito], Eurípides foi capaz de quebrar as expectativas dos espectadores e aumentar o suspense".

A argumentação deste tópico, porém, antevê nas escolhas míticas feitas pelo poeta questões que superam o gênero dramático. Será sustentada aqui, portanto, a hipótese de que alterações de informações concernentes ao plano mítico são consequências da influência do gênero "mitográfico" na feitura da peça As Fenícias. É preciso sempre se ressaltar que o mito por si só corresponde a uma instância cultural da sociedade grega, e o manejar e o trabalhá-lo nunca são ingênuos. De fato, como pressuposto dessa mentalidade mítica, sejam consideradas as palavras de Dowden (1994, p.122):

Não importa o quanto o mito local nos parece ficcional ou artificial: é sempre capaz de ser tratado estritamente como história pelas partes interessadas. O mito, como a propaganda, é valioso porque as pessoas acreditarão nele (...). A argumentação mítica recebe o mesmo respeito que a argumentação histórica teria em nossos dias - ou seja, é persuasiva dentro dos limites permitidos pelas razões mais pragmáticas do interesse próprio e da prática política.

Assim, dentro dessa perspectiva, nota-se que Eurípides compôs As Fenícias em um momento em que Grécia, de modo geral, buscava entender o que seria o "mito". De fato, pertencem ao século V a.C, nomes como Hecateu de Mileto (c. 546 - 480 a.C), Helânico de Lesbos (c. 490- 400 a.C), Heródoto de Halicarnasso (c. 485 - 420 a.C), Tucídides de Atenas (c. 460 - 400 a.C) e Ferecides de Atenas (c. 450 - 400 a.C). Historiografia, mitografia e atidografia são alguns dos títulos atribuídos aos gêneros literários das obras desses autores. Todas elas, como se verá a seguir, tinham em comum o questionamento a respeito da natureza do mito.

Neste momento, pretende-se construir um aporte teórico para a questão do mito per se, ou seja, o mito entendido independentemente de qualquer gênero literário, a fim de se compreender, posteriormente, como a mythopoiesis (construção do backgound mítico) trágica de Eurípides foi dependente ou independente de sua tradição mítica. 
Para os fins desta dissertação, interessa expor os novos rumos teóricos a respeito do mito à maneira de panorama. Para isso, dois estudiosos serão escolhidos como representantes: Hecateu de Mileto e Tucídides de Atenas: este, contemporâneo a Eurípides, aquele, cronologicamente anterior. Tal exposição é relevante, pois permite visualizar os avanços especulativos concernentes ao mito dos quais o tragediógrafo (nos seus últimos anos, período em que encenou As Fenícias) pode ou não ter intelectualmente usufruído.

Sobre Hecateu de Mileto $^{39}$, ressaltar-se-á particularmente a elaboração de uma nova abordagem para o mito, a saber, a "racionalização": "como é consensual, este é um método especialmente associado a Hecateu (talvez sua própria invenção ${ }^{40}$ )". Se, como diz Dowden (1994, p.64), o historiador de Mileto começou a "racionalizar" os mitos, é preciso se definir o que exatamente se entende por "racionalização". Em síntese, a "racionalização" caracteriza-se por ser um revisionismo dos mitos: ela altera o caráter fantástico ou sobrenatural (irracional) do mito e o transforma em algo crível (racional). Nas palavras de Hawes (2014, p.3):

A interpretação racionalista (...) é uma estratégia interpretativa e narrativa identificável que reflete atitudes específicas com relação ao mito. Essas atitudes incluíam, em um lado, o desejo de preservar o papel dos mitos como poderosa propriedade cultural, e, de outro lado, o reconhecimento de que essas histórias violavam empiricamente as normas percebidas da realidade. Os paradoxos impostos por essas incongruências poderiam apenas ser resolvidos se os mitos gregos fossem transformados em história que fossem apropriadas a uma noção do passado que conduzisse, sem pausa ou ruptura, ao presente. (...) Neste contexto, a mitologia grega passa a ser entendida como uma interpretação errônea do passado que poderia ser revertida para mostrar que essas histórias de monstros fabulosos e de ações sobrenaturais derivam, na verdade, de eventos prosaicos.

\footnotetext{
${ }^{39}$ Ver discussão sobre datação da vida de Hecateu em Fowler (2006, p.39). Nicolai (1997) nota que, modernamente, Hecateu é classificado ora como logógrafo, ora como historiador. Heródoto o chama de

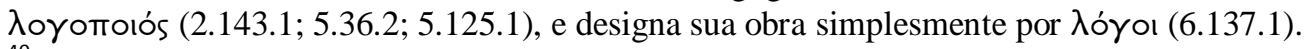

${ }^{40}$ Fowler (1996, p.71).
} 
A partir da obra de Hecateu, inaugura-se, portanto, um novo olhar para o mito ${ }^{41}$. A versão racionalizada, então, não aceita o mítico (ou fantástico) da história ${ }^{42}$, mas não nega a história que vem do mito ${ }^{43}$. Na verdade, desde o prólogo de sua obra chamada Genealogias $^{44}$ (FGrH 1, F.1), o pensador de Mileto já vislumbrava um novo entendimento deste conceito tão caro aos gregos. O caráter sacro e tradicional dessas histórias é assim, portanto, evocado por ele:

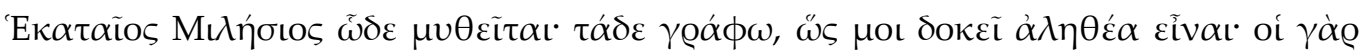

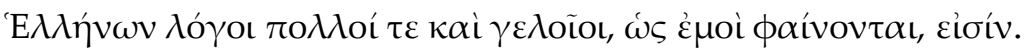

Hecateu de Mileto assim declara: isto escrevo, de acordo com o que julgo verdadeiro, pois as histórias dos gregos são, como me parecem, variadas e risíveis ${ }^{45}$.

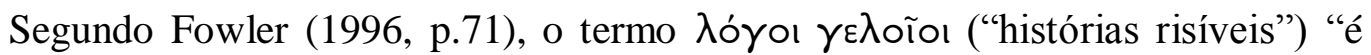
comum e plausivelmente utilizado para se referir aos elementos sobrenaturais dos contos tradicionais que Hecateu propõe eliminar, ou, de certa forma, reduzir, por meio de sua racionalização". Essa nova mentalidade dá origem, então, a um novo gênero literário, hoje conhecido pelos estudiosos como "mitografia ${ }^{46 ", ~ q u e, ~ n a s ~ p a l a v r a s ~ d e ~}$ Bertelli (2001, p.80), “é uma declaração de independência da tradição”. Hecateu, portanto, teria se tornado um dos primeiros a escrever os mitos gregos em prosa ${ }^{47}$, tendo se tornado uma óbvia influência aos que posteriormente fizeram o mesmo: "a influência de Hecateu é visível também em outros escritores, como Acusilau de Argos (fl. 480 a.C)

\footnotetext{
${ }^{41}$ Mitos racionalizados em Hecateu são abundantes. Embora hoje só se conheçam fragmentos de sua obra, Fowler (1996) cita alguns exemplos que mostram claramente como se dava tal procedimento: em FrGrH 1 F 15, por exemplo, Hecateu interpreta Cérbero, tradicionalmente identificado como um monstruoso cão de múltiplas cabeças (algo fantástico), como sendo apenas uma enorme serpente (algo crível).

${ }^{42}$ A título de ilustração, Baragwanath $(2012$, p.18) enumera dois elementos necessários para se racionalizar a história, por exemplo, da guerra de Tróia: 1)evitar o miraculoso e 2)omitir qualquer referência às forças divinas antagônicas que controlavam o campo de batalha da Ilíada.

${ }^{43}$ Bertelli (2001, p.89) ressalva, porém, que "Hecateu por vezes crê também em elementos incríveis do mito, como, por exemplo, o carneiro falante de Frixos (fr. 17) ou Danae engravidando-se por intervenção de Zeus (fr. 21)".

${ }^{44}$ Ver Hawes (2014, p.7).

${ }^{45}$ Tradução do autor.

${ }^{46}$ A palavra "mitografia" teria surgido apenas no fim do século IV a.C, cf. Fowler (2006, p.43).

${ }^{47}$ Cf. Fowler (2006, p.33).
} 
e Ferecides de Atenas ( $f l .465$ a.C), mitógrafos que investigaram e tencionaram trazer uma ordem à tradição grega ${ }^{48,}$.

Para Hawes (2014, p.7), somando-se ao método da racionalização, este prólogo traz uma abordagem nova para com os mitos que representa também uma "nova mentalidade mitológica ${ }^{49}$ ":

Esta notável declaração tem uma autoconfiante inovação que atira uma advertência sobre o arco da mitologia. A autoridade não é mais o meio de conservação da tradição já estabelecida, mas agora ela responde aos cálculos mentais de um indivíduo.

Eurípides, portanto, tinha diante de si um aporte teórico que sobrepunha "os cálculos mentais de um indivíduo", ou seja, a "inovação" autoral, sobre a "autoridade" da tradição, isto é, aquilo que se herdou com o tempo pela repetição oral. O mito, em outras palavras, estava "aberto" para ser explorado e alterado segundo as necessidades poéticas, mas, ao mesmo tempo, passava por uma tendência normalizante que buscava apurá-lo de erros ou inconsistências.

Neste ponto, a obra de Tucídides oferece um tópico que complementa os resultados atingidos por Hecateu. Na sua História da Guerra do Peloponeso, a seção chamada "metodologia" (1. 20-22) apresenta uma palavra bastante representativa do que a "nova mentalidade mítica" pretendia se distanciar: $\mu \cup \theta \tilde{\omega} \delta \varepsilon \varsigma$ ("fabuloso").

Tucídides afirma que, quando os homens estão diante de suas "tradições sobre o

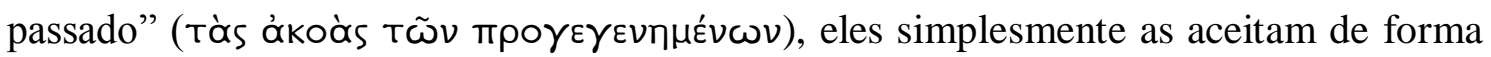

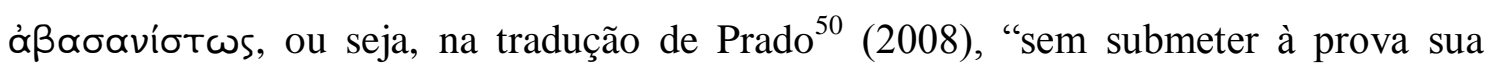
autenticidade". Desse modo, ele conclui que, a respeito dos fatos que ele expusera anteriormente (i.e. na chamada arqueologia), não é possível uma real comprovação porque, assim como ocorre com as narrações dos poetas e dos logógrafos, eles "ganham

\footnotetext{
${ }^{48}$ Marincola (2001, p.16).

49 Dewald (2012, p.60), por exemplo, classifica as histórias fabulosas presentes em Heródoto como pertencentes ao "mundo do antigo pensamento mítico grego" (embora ele também racionalizasse os mitos, cf. Dowden (1994, p.67)). Em oposição a isso é que se decidiu aqui chamar o novo sistema mitográfico proposto por Hecateu de "nova mentalidade mítica".

${ }^{50}$ Todos os trechos aqui utilizados de Tucídides são de sua tradução.
} 


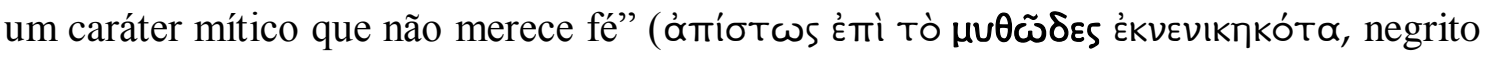

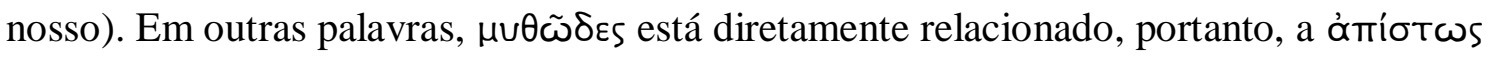
(“incrível").

Mas o que exatamente significa $\mu v \theta \tilde{\omega} \delta \varepsilon s ?$ Segundo Flory (1990, pp. 193-4):

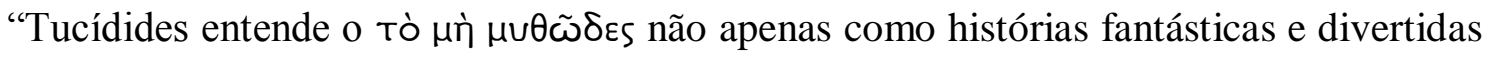
em geral, cuja irrelevância para o seu estudo seria óbvia, mas histórias que exageram e comemoram as glórias da guerra"; ao mesmo tempo, porém, a autora não descarta o sentido que Prado traduziu por "mítico". Marincola (1997, p.117) tem outra interpretação: "há um consenso geral de que por mítico ( $\tau$ ò $\mu v \theta \tilde{\omega} \delta \varepsilon \varsigma$ ) Tucídides entendia o elemento fabuloso ou puramente narrativo de seus predecessores". Com ele também concordam Zaidman e Pantel (1992, p.144): “Tucídides, por exemplo, identificou o 'mítico ${ }^{51}$ ' ( $\left.\mu \cup \theta \tilde{\omega} \delta \varepsilon \varsigma\right)$ com o fabuloso e o excluiu totalmente de sua historiografia".

Enfim, a atitude de Tucídides para com o mito pode ser sintetizada pela negação do $\mu \cup \theta \tilde{\omega} \delta \varepsilon s$. De fato, Detienne (1992, p.109) afirma que: “A História da Guerra do Peloponeso está 'além do mito', ela começa onde acaba, por decreto, a atividade da memória antiga". Assim, para os fins desta dissertação, Hecateu e Tucídides são suficientes para ilustrar a chamada "nova mentalidade mitológica" do século V: aquele por causa da racionalização, este pela explícita negação do mítico ${ }^{52}$.

Do mesmo modo, o gênero trágico também precisava adotar uma postura teórica com relação aos mitos, matéria-prima de seu fazer poético ${ }^{53}$. Assim, uma atitude

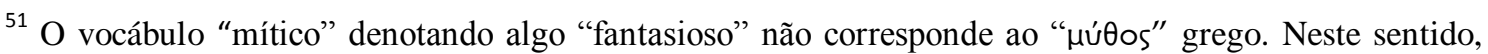

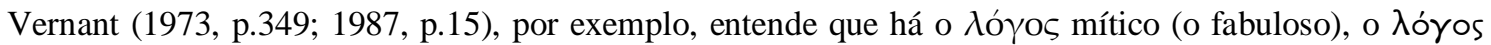
racional (e.g. o discurso filosófico) e o $\mu$ ú os (e.g. Homero e Hesíodo). Dowden (1994, p.65) considera falsa a argumentação que propõe uma linha evolutiva que vai do $\mu$ ú os para o $\lambda$ ó $\gamma$ os.

${ }_{52}$ Outros também poderiam ser citados como representantes desse novo sistema, como Xenófanes, Ferecides, Helânico, mas não seriam tão significativos, para o escopo deste trabalho, quanto Hecateu. Este ao menos, se não é o mais sofisticado, tem o primado cronológico. Heródoto, embora, nas palavras de Asheri (2007, p.30) não possa ser confundido com os mitógrafos e genealogistas de sua época (i.e. os mencionados acima), apresenta a mesma dualidade de Hecateu: ao mesmo tempo em que racionaliza mitos, ainda não se libertou por completo do $\mu v \theta \tilde{\omega} \delta \varepsilon s$ de que fala Tucídides. Murray (2001, p.25), por

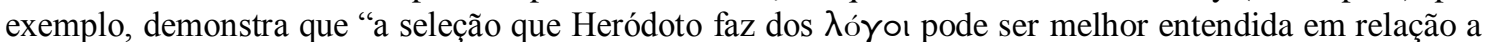
uma distinção entre $\lambda$ ó verdadeiro".

${ }^{53}$ Mcdermott (1991, p.123) e Allan (2008, p.18) notam que a tradição mítica grega era multiforme. Mesmo que o tragediógrafo não traga nenhuma inovação ao mito, ele se vê obrigado a fazer escolhas entre uma ou outra versão da mesma história. Dowden $(1994$, p.122) nota que tais escolhas nem sempre eram desinteressadas: "a argumentação mítica recebe o mesmo respeito que a argumentação histórica teria em nossos dias, ou seja, é persuasiva dentro dos limites permitidos pelas razões mais pragmáticas do interesse próprio da prática política".
} 
imediata a ser tomada pelo poeta dizia respeito à escolha dos fatos de um mito a serem encenados. Sobre esse assunto, Allan (2008, p.27) introduz o conceito de "verificabilidade":

Verificabilidade é um ponto importante na feitura grega dos mitos [myth-making] (o poeta não pode inovar arbitrariamente, mas ele precisa tomar cuidado em integrar suas alterações dentro dos relatos já familiares para sua audiência) e a melhor maneira para lidar com o desafio da verificabilidade é fazer antes o novo aparentar velho - daí a importância da tradição épica da criação de enredos trágicos.

À vista disso, resta analisar se o texto de Eurípides possui algum elemento literário que permita dizer, de fato, que a intenção do poeta foi além da construção dramática. Note-se que As Fenícias, para dramatizarem a querela entre os filhos de Édipo, lançam mão de numerosos flashbacks a respeito da história da fundação de Tebas. A audiência que acompanhava a encenação pode contemplar muito do mito que circunscrevia a ação central da peça, ou, nas palavras de Lamari (2010, p.17), teve uma visão panorâmica do que antecedia ao caso: "Eurípides aspira criar um panorama de Tebas, no qual quantidade abundante de informação mítica fica a disposição da audiência" (negrito nosso).

Finalmente, a fim de exemplificar a hipótese sugerida aqui a respeito do procedimento mitográfico do tragediógrafo, o caso da nomeação e da consolidação da identidade de Jocasta servirá como paradigma. Em estudo anterior de Iniciação Científica do autor ${ }^{54}$, foi realizada uma pesquisa detalhada sobre os diferentes nomes da mãe de Édipo encontrados em diferentes fontes textuais anteriores ou coetâneas a Eurípides, assim como sobre seu papel como cônjuge desse personagem. Resumidamente, é possível mostrar na seguinte tabela os resultados então obtidos:

\begin{tabular}{|l|l|l|l|l|}
\hline & Homero & Edipodia & Ferecides & As Fenícias \\
\hline $\begin{array}{l}\text { Nome da mãe } \\
\text { de Édipo }\end{array}$ & Epicasta & - & - & Jocasta \\
\hline
\end{tabular}

\footnotetext{
54 "Eurípides entre o mito trágico e o mito tradicional aristotélico: tradução e estudo do prólogo de $A s$ Fenícias", 11/2010 - 11/2011, FAPESP.
} 


\begin{tabular}{|l|l|l|l|l|}
\hline $\begin{array}{l}\text { Filhos de } \\
\text { Édipo com } \\
\text { Jocasta }\end{array}$ & $\begin{array}{l}\text { Não } \\
\text { mencionado }\end{array}$ & Sim. Eurigania & Sim. Eurigania & Não \\
\hline $\begin{array}{l}\text { Segunda } \\
\text { esposa? Nome }\end{array}$ & & Sim & Sim & \\
\hline $\begin{array}{l}\text { Filhos com } \\
\text { segunda esposa }\end{array}$ & & & Sim. & \\
\hline $\begin{array}{l}\text { Terceira } \\
\text { esposa? Nome }\end{array}$ & & & Astimedusa & \\
\hline
\end{tabular}

No caso de Homero, não é mencionado se Epicasta teve filhos de Édipo, mas sabe-se que ela se matou devido ao descobrimento da verdadeira identidade de Édipo (Odisseia, XI, 271-280). O mesmo ocorre na versão de Sófocles ${ }^{55}$ (Édipo Rei). March (1987) ainda mostra que Eurigania seria irmã da mãe de Édipo, i.e. Jocasta, e que Astimedusa era neta de Perseu e Andrômeda.

Em As Fenícias, quem apresenta o nome de Jocasta é a própria Jocasta, logo no prólogo da peça (12-13):

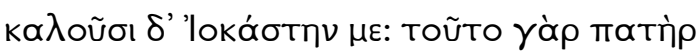

हैं $\theta$ тто.

E me chamam Jocasta, pois esse nome meu pai

Me deu.

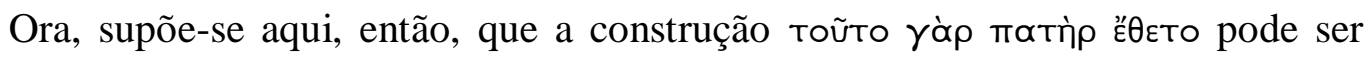
vista como um ponto final que Eurípides pôs à questão a respeito do nome da mãe de

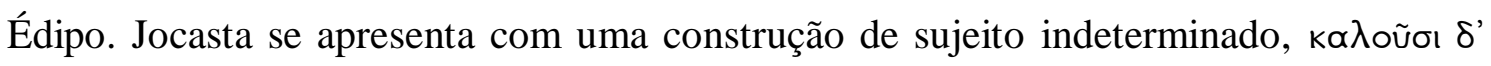
'lokóotᄁv $\mu \varepsilon$, e, em seguida, ajunta uma explicação (feita à maneira dos versos épicos ${ }^{56}$ ) que diz "pois esse nome meu pai pôs", numa tradução literal. Mastornarde (1994) também levanta essa hipótese em seu comentário, mas ressalva que "seria estranho que

\footnotetext{
${ }^{55}$ Ésquilo e Sófocles não foram listados na tabela por não apresentarem diferenças, naqueles quesitos, com relação a Eurípides.

${ }^{56}$ No caso, trata-se do mendigo Arneu. Assim essa personagem é apresentada na Odisseia (18.5):

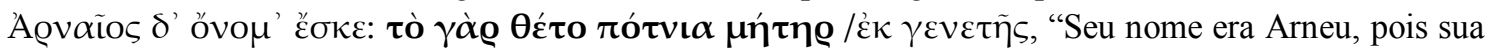
soberana mãe o pôs desde seu nascimento" (tradução do autor). Trecho semelhante ao de Eurípides está em negrito.
} 
Eurípides tenha se importado com o detalhe" (1994, p.145). De fato, ele prefere ver esses dois versos como um paralelismo dos versos 57-8:

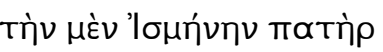

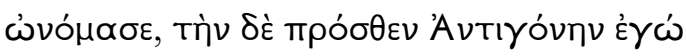

Uma, Ismene o pai a chamou

E, a mais velha, Antígone nomeei.

Contudo, a interpretação dada por Mastronarde parece pouco precisa. Não é possível concordar que o caso se trate de um simples detalhe, porque, como se vê a partir da tabela mostrada acima, ele traz modificações substanciais ao mito: não se trata apenas de um nome, mas de quem era a esposa e a mãe dos filhos de Édipo. Haja aí paralelismo ou não, como quer Mastronarde, o fato é que uma opção (paralelismo) não exclui a outra (definir os dados da tradição). Além disso, esses dois versos citados, juntamente com os dois precedentes que nomeiam os filhos homens, enfatizam que os quatro filhos de Édipo, Etéocles, Polinices, Antígone e Ismene são também filhos de Jocasta, não de uma outra mãe ou de um outro casamento. Com efeito, como Jocasta manifesta nos dois versos posteriores, foi por causa do incesto, ou seja, por causa de uma relação com alguém da própria família, que Édipo atenta contra a própria visão. Evidentemente, portanto, ao contrário de todas as outras versões, Eurípides assinala aqui que Édipo não teve nem segunda nem terceira esposa e que teria, sim, se cegado.

Desta sorte, são duas as motivações que conduzem esta dissertação a interpretar tais alterações míticas para além da construção cênica e de seus efeitos na audiência. Para além dos argumentos de nível sintático das orações, o primeiro eixo argumentativo, pode-se estabelecer também uma comparação que recorra à questão de gêneros textuais. O próximo objetivo desta subseção será, então, conjecturar as semelhanças entre o "monólogo de Jocasta" e dois gêneros complementares que se estabeleceram no século V a.C, a saber, a mitografia e atidografia. 
De fato, o tratamento dado por Eurípides ao mito de Édipo muito se assemelha ao trabalho de pesquisadores do mito que ficaram conhecidos como "mitógrafos 57 ". Chamados por Dowden (1994, p.26) de "para-historiadores", eles se ocuparam em registrar sistematicamente por escrito, em prosa, os numerosos mitos que circulavam oralmente na Grécia. Fowler (2000, p.40), cuja pesquisa demonstra ser a "mitografia" um gênero literário autônomo, assim sintetiza uma de suas características que bastante se assemelha com o que se vê no prólogo de As Fenícias: "a mais forte tendência da mitografia é contar a história de forma mais econômica possível". Dessa forma, ele descreve o ritmo das narrativas dos mitógrafos como sendo "sumário".

$\mathrm{O}$ número de obras deste gênero que foram compostas no século $\mathrm{V}$ a.C, bem como o número de autores, é considerável. Fowler (2006, p.39-41) enumera pelo menos vinte mitógrafos que tenham realizado sua obra mais ou menos no período de vida de Eurípides. Dentre esses, é conveniente destacar um, Helânico de Lesbos, pois é o que está temporalmente mais próximo do tragediógrafo em questão - na verdade, a data (aproximada) de nascimento e de morte de ambos coincide ${ }^{58}$.

A quantidade de títulos referentes às obras compostas por Helânico é vasta: Fowler (2006, p.40) enumera pelo menos quarenta. Considerado por estudiosos como o fundador da "atidografia", notar-se-á que há grande quantidade de semelhanças entre esse gênero e o prólogo de As Fenícias. Fundamentalmente, a atidografia, como define Jacoby (1949, p.86), “constitui-se de um gênero literário que contém narrativas cronológicas sobre Atenas”. Atidografia e mitografia são gêneros irmãos: aquele, mais recente, distingue-se por se focar unicamente nos mitos relativos à história da Ática. O que permite a aproximação com o prólogo da peça em questão é o fato de esse gênero se caracterizar por ter uma forma sequencial, isto é, os eventos eram contados sucessivamente, sem interrupção ${ }^{59}$, e justamente essa sequencia muitas vezes se iniciaria $a b$ ovo, ou seja, pelos heróis fundadores da região.

Mas não é apenas no nível formal que tais aproximações podem ser feitas. Helânico, assim como se viu em Eurípides, também realizava alterações nos mitos com que trabalhava. De forma geral, os atidógrafos com suas obras estavam inventando Atenas desde o seu primórdio e, nas palavras de Harding (2008, p.xii): “eles estavam

\footnotetext{
${ }^{57}$ É costume hoje tratar tais pesquisadores como "mitógrafos", mas a palavra "mitografia" teria surgido pela primeira vez apenas no final do século IV a.C, cf. Fowler (2006, p.43).

${ }_{58}^{5}$ Eurípides (c. 480 - 406 a.C), Helânico (?480/79 - depois de 407/6 a.C), cf. Fowler (2006, p.40).

${ }^{59}$ Cf. Jacoby (1949, p.87).
} 
usando, abusando ou manipulando as tradições orais com a finalidade de fornecer uma base pseudo-histórica para as práticas religiosas, jurídicas, sociais e administrativas de Atenas".

Especificamente sobre Helânico, escreve ainda Harding (2008, p.6):

Helânico estabeleceu a estrutura básica e a forma da Atidografia (...). Escrevendo em um momento de intenso nacionalismo e chauvinismo em Atenas (a Guerra do Peloponeso), ele sem dúvida encontrou as interpretações patriotas do passado de Atenas que estavam sendo promovidas pela tradição da pólis em outros meios de comunicação, como a literatura (especialmente a tragédia) e as artes visuais.

Destarte, o fato de o prólogo de As Fenícias ser breve, sumário, sequencial, apresentando uma narração $a b$ ovo, e com determinadas alterações mitológicas, sugere uma aproximação entre a obra desses autores. A seguir, ver-se-á a estrutura do prólogo da peça em questão, comparando-o juntamente com um trecho do êxodo (1595-1624). A primeira parte consiste de um trecho do "monólogo de Jocasta" e o segundo, de uma rhesis de Édipo.

Jocasta abre o prólogo com uma invocação ao Sol. Essa invocação é, na verdade, um lamento por conta de fatos passados que trouxeram a desgraça para a cidade de Tebas. Jocasta faz a delimitação temporal do início dessas desgraças com o sintagma

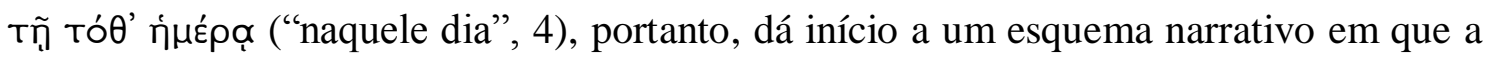

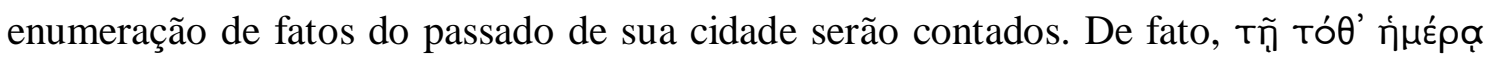
(4) está identificado com a chegada de Cadmo ao lugar onde mais tarde será fundada Tebas. É proposta então uma regressão histórica $a b$ ovo.

Além do aspecto temporal, o espacial também está bem delimitado. Jocasta

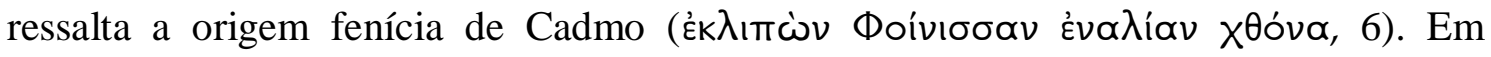
seguida, Jocasta apresenta de forma compacta uma genealogia dos filhos de Cadmo, valendo-se também de demarcadores temporais (no caso, потѐ, 7): Cadmo se casa com a filha da deusa Afrodite, Harmonia (7), e gera Polidoro (8), que gera Lábdaco (8), que gera Laio (9). 
Todas essas informações estão contidas nos nove primeiros versos de $A s$ Fenícias. Esquematicamente, forma-se o seguinte diagrama:

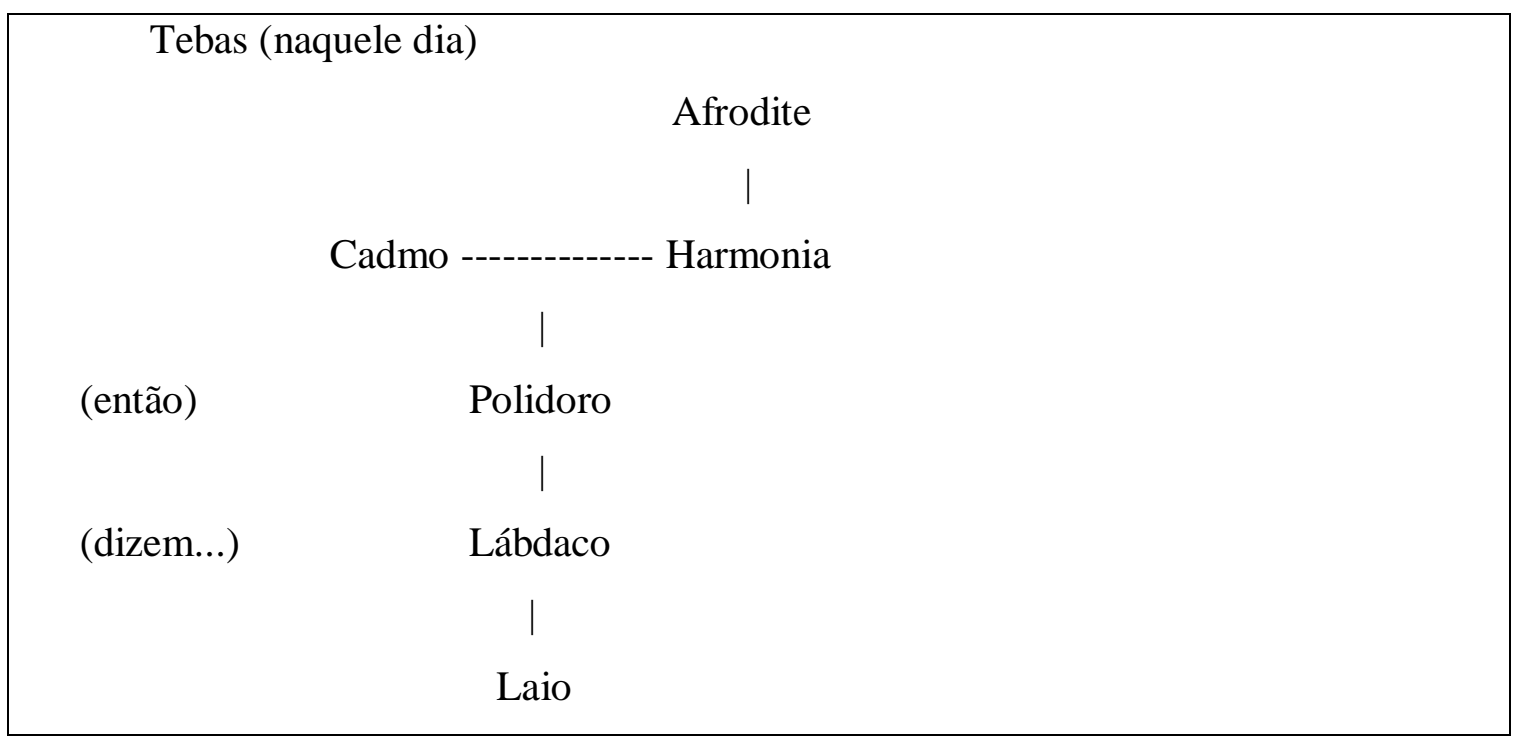

É interessante notar que Jocasta utiliza o verbo $\lambda \dot{\gamma} \gamma \omega$ (“dizer”) na terceira pessoa do plural, no presente do indicativo, para se referir a essa história. Esse "dizem", contudo, não necessariamente confere a seu relato um caráter menos verdadeiro. De fato, parte dessa genealogia será retomada pelo coro no segundo estásimo (822).

Amiech (2004, p.240) nota que essa genealogia está bastante resumida. Ela mostra, então, que não é feita menção, por exemplo, do pai de Harmonia (Ares), nem dos filhos mais "célebres" de Cadmo, como Agave ou Ino. Ora, se se pretendeu, como se argumenta aqui, conferir objetividade e síntese à exposição da genealogia, inserindoa dentro do relato mítico, então a ressalva feita por Amiech seria impertinente.

Curiosamente, como em paralelo ao prólogo, o êxodo também refaz a narrativa mítica de Édipo. De forma mais compacta, é certo, agora é o próprio Édipo quem, no findar do drama, relata o que Jocasta expôs na abertura. Para Amiech (2004, p.570), “essa fala [de Édipo] equivale, em um modo patético, ao monólogo de abertura de Jocasta que tencionava apresentar os fatos de maneira objetiva". Muito, porém, essa repetição narrativa contribuiu para que se criticasse a peça de tematicamente redundante e excessiva. Tal crítica não leva em consideração o caráter megatextual em que se pode interpretar a peça: conforme nota Lamari (2010, p.23), Eurípides está trabalhando com 
uma vasta gama de informações nem sempre idênticas a respeito do mito circunscrito no Ciclo Tebano. O gênero trágico, portanto, e essa é a hipótese desta dissertação, parece estar se aproximando, ou melhor, tomando emprestados certos elementos do gênero mitográfico. Os versos ${ }^{60}$ são (1595-1614):

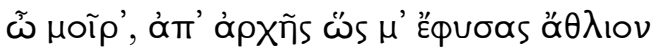

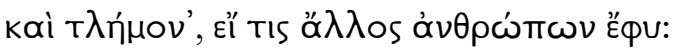

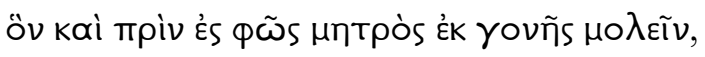

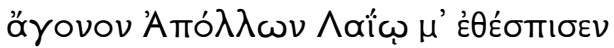

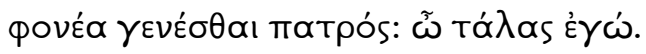

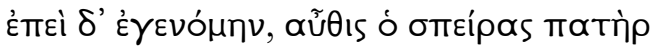

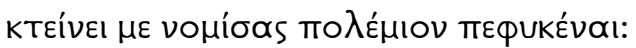

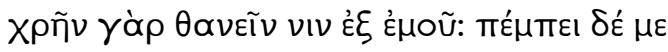

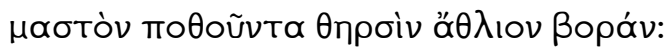
ỡ $\sigma \omega \zeta \dot{\mu} \mu \varepsilon \sigma \theta \alpha-T \propto \rho T \alpha ́ \rho o u ~ \gamma a ̀ \rho ~ \omega ̋ \phi \varepsilon \lambda \varepsilon v$

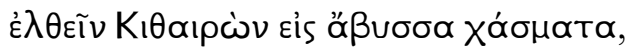

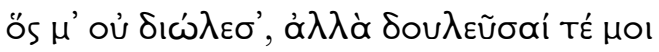

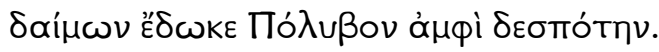

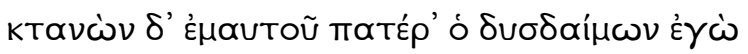

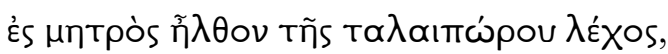

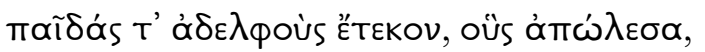

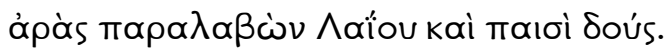

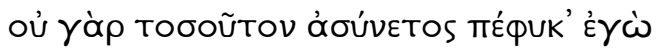

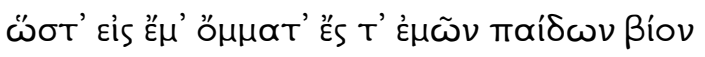

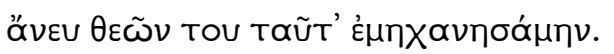

Ó Fado, desde o início, como me fizeste desditoso!

\{E desgraçado, como a nenhum outro fizeras. $\}$

\footnotetext{
${ }^{60}$ Há suspeita de interpolações neste trecho, e há certos editores que recomendam a eliminação de certos versos. Ver análise completa em Mastronarde (1994, p.598), que se posiciona pela manutenção integral do trecho.
} 
Antes mesmo de vir à luz pelo ventre materno,

Apolo profetizava a Laio que eu, ainda inato,

Tornar-me-ia assassino de meu pai. Ai de mim.

Assim que nasci, meu pai, aquele que me gerou,

1600

Tenta me matar, julgando ter gerado inimigo seu -

Fadado estava a ser morto por mim. Faz de mim,

Inda lactente, mas já desditoso, pasto de feras.

Disso fui salvo - mas mais valia que o Citerão

Precipitasse-se no insondável abismo do Tártaro.

1605

Ele não me matou, mas como um serviçal

O deus me designou no paço de Políbio.

Desgraçado, eu tiro a vida de meu próprio pai,

Deito-me no leito conjugal de minha mãe,

Gero filhos que são meus irmãos, arruíno-os,

1610

Transmitindo aos dois as maldições de Laio.

Não sou tão insensato a ponto de ter tramado

Tais desgraças para os meus olhos e para a vida

De meus filhos sem a indução de um dos deuses.

Lamari (2010, p.114) nota que a narração de Édipo se constrói por analepse e que "a partir deste lugar de observação, Édipo parece emprestar a onisciência de um narrador principal que está na posição de oferecer uma vista panorâmica do mito". Mastronarde (1994, p.592) faz um comentário do ponto de vista do tragediógrafo: "o dramaturgo desejou criar uma imagem de um determinado mundo, provido de males explicáveis e inexplicáveis, com aspirações e frustrações, afetando um grupo coeso de indivíduos e sua comunidade".

As palavras-chave que devem ser destacadas daí são: "narrador", "vista panorâmica do mito" e "imagem de um determinado mundo". Não é assim que se fundamentava o gênero mitográfico?

A estrutura temporal do trecho acima é linear. Os verbos, que se alternam entre o tempo presente e aoristo, formam uma sequencia cronologicamente ascendente, 
cobrindo toda a vida de Édipo. É possível se verificar essas afirmações por meio do seguinte diagrama verbal:

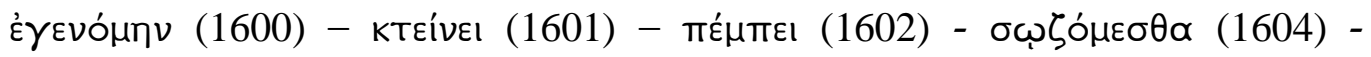

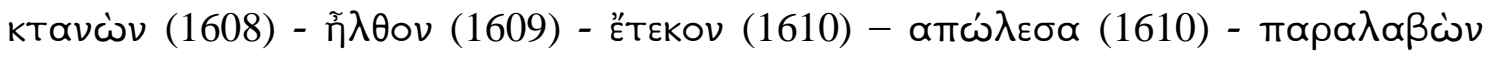
(1611) - Soús (1611).

Logicamente, não é intenção se afirmar aqui que tal trecho era rigorosamente

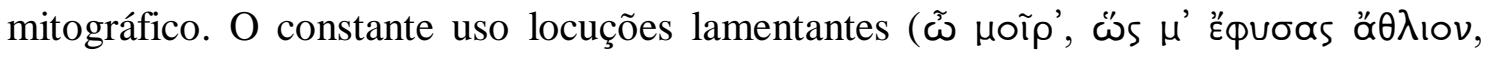

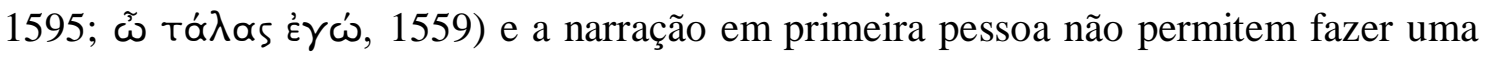
equiparação a tal nível. A intersecção de determinadas características, porém, é visível, como ficou demonstrado acima.

A insistente repetição dessas informações não passa despercebida, considerandose estar inserida em uma obra de gênero poético. Na verdade, como diz Aristóteles na Poética, "o elemento principal [entre os elementos de uma tragédia] é o arranjo das

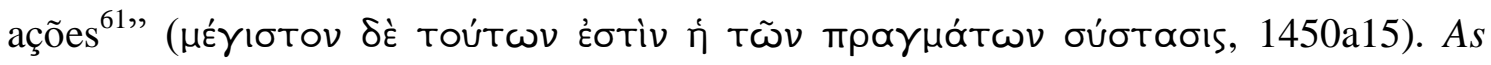
Fenícias, porém, mostram que a narrativa mítica (não o $\mu$ ũ 0 s aristotélico ${ }^{62}$, que designa a trama dos fatos, ou o enredo) ocupa lugar de grande relevo. É certo que o “arranjo de ações" não é prejudicado por causa dessa forte preocupação do poeta para com a exposição dos dados da tradição; ao contrário, ela revela uma inovação para o gênero trágico.

\subsection{As Fenícias e a mythopoiesis do Ciclo Tebano}

Como se viu na seção 1.2, o canto coral de As Fenícias versa longamente sobre a história da fundação de Tebas, bem como seus desenvolvimentos posteriores. Gregory (2005, p.258) observa que cantos corais míticos são uma característica do estilo tardio de Eurípides, e que, devido a tal natureza, eles já foram chamados de "ditirâmbicos”: “o

\footnotetext{
${ }^{61}$ Tradução do autor.

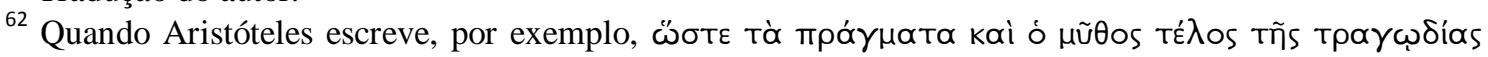
(“de modo que a ação e o enredo são o fim da tragédia”, Poética, 1450a22, tradução do autor).
} 
nome faz supor que as odes corais são ensimesmadas e desconectadas da ação dramática, mas um estudo apurado revela o contrário". Resta agora detalhar a estrutura e o padrão poético dessa narrativa mítica a fim de se observar que papel tem o mito dentro da ação dramática da peça. Pretender-se-á entender, então, se a junção mito-ação pode produzir um significado dramático ${ }^{63}$.

O primeiro estásimo (638-689) condensa um intervalo de tempo da história de Tebas relativamente longo: ele abrange a chegada de Cadmo a Beócia, a morte do dragão de Ares, o nascimento dos Semeados e o nascimento de Dioniso. Da maneira como está disposta e sobre o local que ocupa na peça, Arthur (1977) faz duas observações complementares: primeiramente, o estudioso vê o tema da fundação de Tebas aí exposto como uma sugestão de continuidade entre as lutas do passado e do presente ${ }^{64}$. Analogamente, ele sugere que o primeiro estásimo se construa em uma estrutura chamada por ele de "oposição dialética": a estrofe remeteria à parte pacífica da fundação de Tebas, enquanto a antístrofe à parte belicosa ${ }^{65}$.

A interpretação de Arthur (1977), portanto, vê no mito um reflexo do que é encenado pelos personagens na ação dramática. Deste modo, a história de Tebas estaria sujeita a um movimento pendular oscilando entre a salvação e a perdição: Cadmo, ao mesmo tempo que é o herói fundador e civilizador da cidade, é também aquele que mata o dragão de Ares, gerando uma dívida de sangue que terá de ser paga pela cidade mais tarde (nesse caso, o sacrifício de Meneceu). A trajetória de Édipo se encaixaria no mesmo esquema: ele é quem salva a cidade da Esfinge, e, ao mesmo tempo, é ele quem amaldiçoa seus filhos, causando a disputa entre Etéocles e Polinices.

Estruturalmente, o primeiro estásimo apresenta uma disposição triádica, sendo que a estrofe (638-656) e a antístrofe (657-675) fazem um contraste conceitual com o epodo: as duas primeiras partes dizem respeito à história da fundação de Tebas, enquanto que o epodo (676-689) contém uma prece ${ }^{66}$ proferida devido às circunstâncias do momento dramático. Amiech (2004, p.383) confere a esse estásimo um caráter

\footnotetext{
${ }^{63}$ Aqui se encerra o objetivo deste primeiro capítulo. No capítulo seguinte, a relação será mito e significado extra-dramático.

${ }^{64}$ Arthur (1977, p.169).

${ }^{65}$ Arthur (1997, p.173). Do mesmo modo, para ele o párodo faria a oposição entre a Tebas belicosa e a Delfos pacífica, ver Arthur (1977, p.165-9).

${ }^{66}$ Ver estudo sobre essa prece no capítulo 2.
} 
"pacificador", já que ele se posiciona depois da crescente tensão gerada no primeiro episódio por conta da altercação entre Etéocles e Polinices.

Há que se notar, contudo, que a estrofe e a antístrofe são construídas também em um contraste tonal: aquela é jubilosa, pois relaciona à fundação de Tebas o nascimento de Dioniso, esta é aflitiva, pois relaciona à fundação de Tebas a morte do dragão de Ares (vocábulos pertencentes ao campo semântico de qóvos ("morticínio") e ő $\lambda \lambda u \mu ı$ (“destruir") aparecem cinco vezes). Ambas, porém, apresentam uma estrutura narrativa semelhante: além de conterem o mesmo número de versos, elas se constroem segundo um mesmo padrão que será identificado aqui por três partes distintas: "apresentação", "explicação" e "desenlace".

O verso inicial da estrofe e da antístrofe são construídos com uma estrutura idêntica (não necessariamente na mesma ordem): sujeito gramatical, verbo (indicando tempo pretérito), adjunto adverbial de lugar e adjunto adnominal (de procedência). A

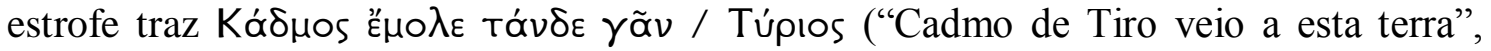

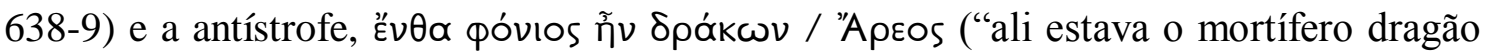
de Ares", 657-8). Assim, esses dois versos iniciais servem de apresentação dos protagonistas das histórias que cada parte se incumbirá de contar, e, por isso, aqui será chamado simplesmente, para fins de classificação e organização, de "apresentação".

Em seguida, estrofe e antístrofe fornecem informação a respeito do local delimitado na "apresentação". Essa parte será aqui chamada de "explicação". Em ambas partes, explica-se o porquê do verbo e do adjunto adverbial da "apresentação". Assim,

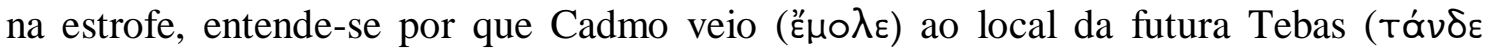
$\gamma \tilde{a} v)$, enquanto que, na antístrofe, entende-se por que o dragão ( $\delta \rho a ́ k \omega v)$ estava (ก̃v) na terra da futura Tebas (

A explicação, porém, para cada caso se estende em quantidade de versos diferentes. Na estrofe, explica-se que Cadmo veio a Tebas por causa de um oráculo ${ }^{67}$ (639-648). Na antístrofe, explica-se que o dragão estava na terra da futura Tebas para vigiar uma fonte de água do local (659-661).

\footnotetext{
${ }^{67}$ Ver no Apêndice desta dissertação tradução do escólio referente ao oráculo de Cadmo (escólio ao verso $638)$.
} 
Por fim, tem-se a introdução de novo personagem e de eventos que se relacionam com a localidade fornecida na "apresentação". Essa parte chamar-se-á aqui “desenlace", pois fornece uma conclusão narrativa às duas partes antecedentes. No caso da estrofe, relata-se o nascimento de Dioniso no local onde Cadmo, vindo de Tiro, se assentou (649-656). Quanto à antístrofe, relata-se como Cadmo matou o dragão e as consequências desse morticínio (662-675).

Esquematicamente, portanto, tem-se:

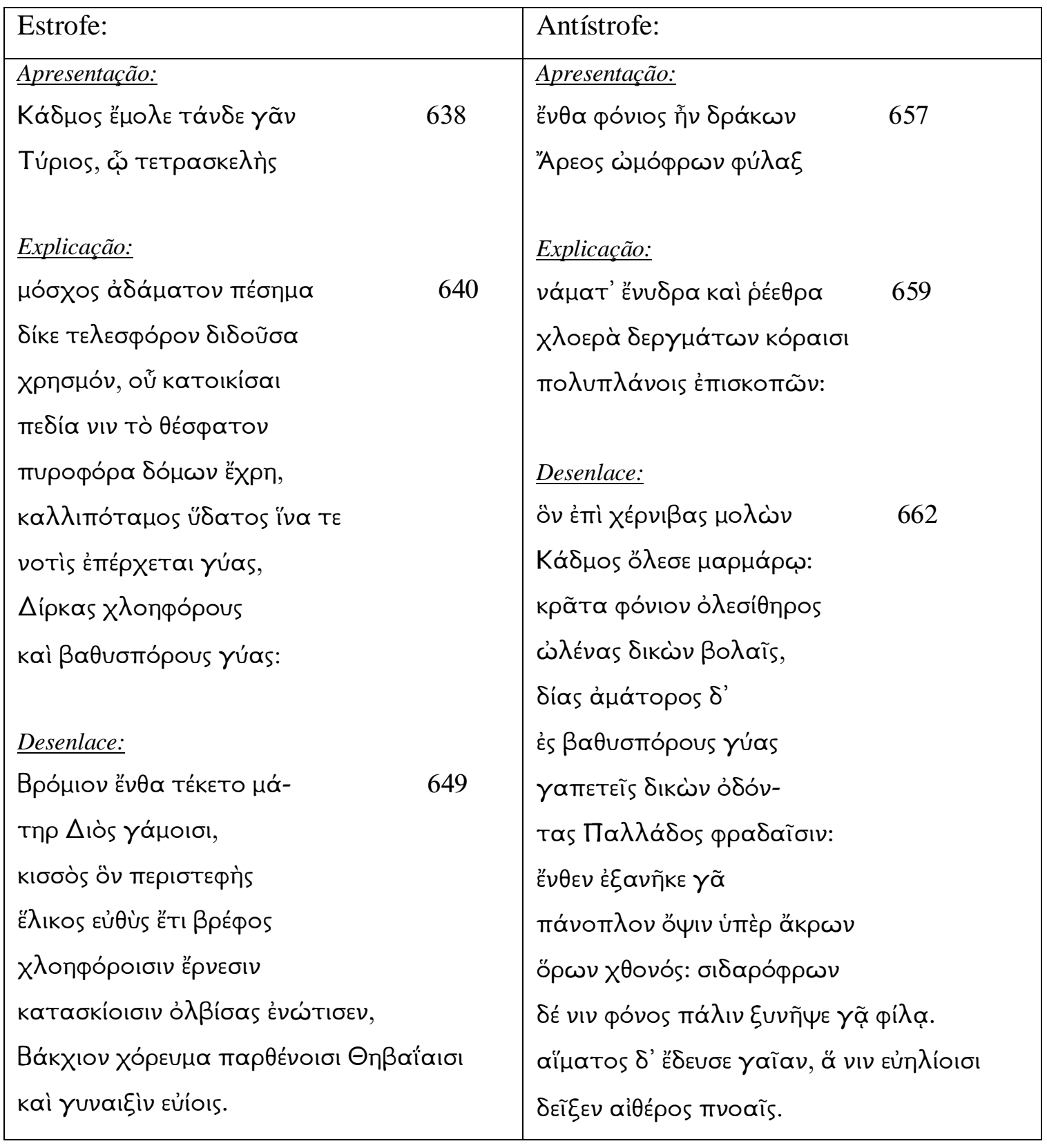




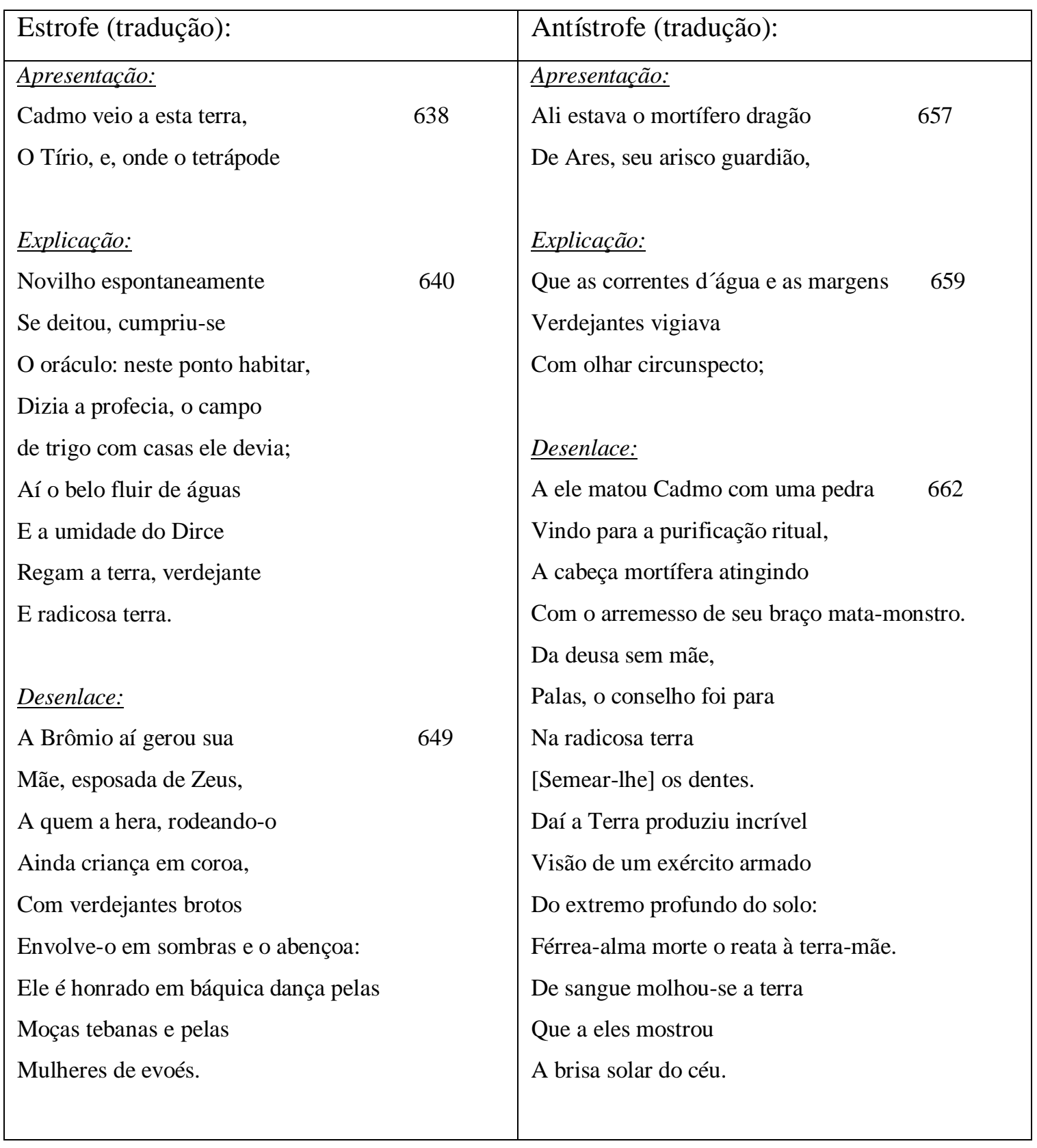

A função do coro tanto na estrofe como na antístrofe é essencialmente narrativa. Não há preces nem qualquer espécie de comentário referente aos acontecimentos vivenciados pelo coro naquele momento. O tema dessa narração já fora rapidamente tracejado por Jocasta no prólogo (5-6), mas aqui se tem um delineamento mais extenso dos fatos relacionados à fundação de Tebas. A cronologia dos fatos, então, pode ser disposta na seguinte ordem:

(estrofe)

1- Cadmo vem de Tiro (Fenícia) para a terra da futura Tebas; 
2- Cumprimento do oráculo: Cadmo deve habitar a região do (rio) Dirce;

3- Região do Dirce é local de nascimento do Dioniso, filho de Zeus.

(antístrofe)

1- Dragão de Ares vigiava a região do Dirce;

2- Cadmo, a procura de água lustral, mata o dragão de Ares com uma pedra;

3- Deusa Palas ordena que Cadmo lance dentes do dragão na terra;

4- Terra faz nascer um exército a partir dos dentes do dragão;

5- Esse exército é morto e volta para a Terra.

Assim As Fenícias delineiam a história da fundação de Tebas. No tempo de Eurípides, porém, havia diversas outras tradições a respeito desse assunto. Como o tragediógrafo manipulou esses dados, quais débitos mitológicos e propostas dramáticas ele pretendeu conferir a sua criação com tal manipulação é o que se pretende investigar agora. Para isso, dois pontos serão o centro dessa discussão: a origem de Cadmo e a questão de quem foi o fundador de Tebas.

Na peça As Fenícias, a origem fenícia de Cadmo é mencionada duas vezes:

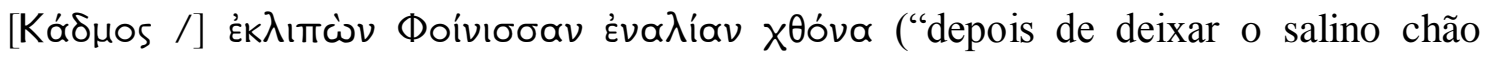

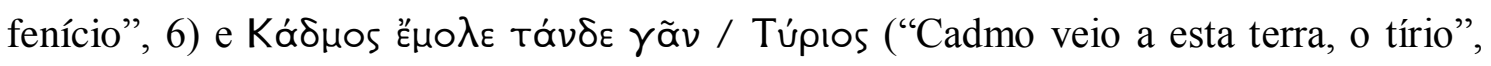
638). Contudo, não há unanimidade entre diferentes fontes acerca do local de proveniência deste personagem. Mesmo dentro da obra de Eurípides, por exemplo, há informações desencontradas: se em As Fenícias ele é de Tiro (638), em As Bacantes (170-2) e na peça fragmentária Frixo B (F 819), ele é de Sídon.

Essa discrepância, porém, não parece ser devida a um desleixo mitográfico do poeta. Na verdade, Edwards (1979, p.46) explica que tal inexatidão geográfica era comum em fontes literárias dessa época: "a diferença das fontes literárias entre Tiro e Sídon como a cidade de origem de Cadmo não precisa ser pressionada, uma vez que ambas as cidades, Tiro e Sídon, parecem ser utilizados, sem muito rigor, como sinônimos de "fenícia"”.

Em comparação com outros tragediógrafos, Eurípides é quem mais se ocupou do tema. Sobre Sófocles, por exemplo, Gomme (1913, p.68) diz que o poeta "parecia não ter se interessado em Cadmo ou nos fenícios: em suas três peças sobre Tebas, ela apenas

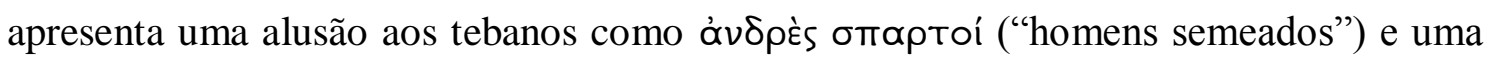




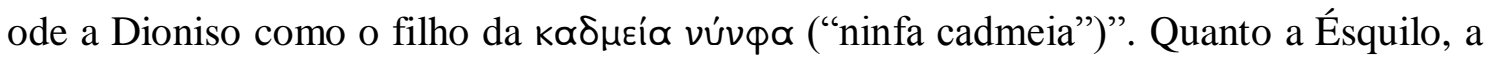
mesma escassez de dados é notada. Segundo Gomme (1913, p.65), apenas nos Sete Contra Tebas há menção a Cadmo, mas não há referência à sua origem.

Tampouco Homero e Hesíodo fornecem outros pormenores a respeito da origem de Cadmo. Em Homero, apenas se menciona que Cadmo é pai de Leucoteia (Odisseia, V, 333), e, em Hesíodo, Cadmo é apenas descrito como esposo de Harmonia (Teogonia, 937) e como pai de Ino, Sêmele, Agave e Polidoro (Teogonia, 976-8). Este último ponto ainda uma vez mais ilustra a discordância interna que há na obra de Eurípides. Enquanto em As Fenícias Cadmo é descrito como pai de Polidoro (8), em As Bacantes diz-se que Cadmo não teve filho homem (1305).

Entre os poetas "líricos" anteriores ou coetâneos a Eurípides, Estesícoro possui um poema ligado ao ciclo mítico tebano conhecido como Tebaida ${ }^{68}$ (fr. 222b). Do mesmo modo, a única referência possível de se extrair daí a respeito de Cadmo se limita

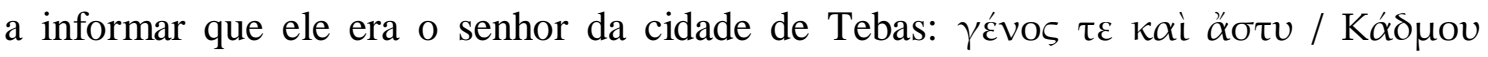
ăv $\alpha \kappa \tau o \varsigma$ ("a prole e também a cidadela / do soberano Cadmo", 228-9). Píndaro, por sua vez, mostrava um Cadmo autóctone, isto é, de origem tebana, não estrangeira (fr. 25).

Heródoto, por outro lado, se debruça longamente na história de Cadmo e fornece informações precisas sobre sua origem. Segundo este historiador, Cadmo era fenício, proveniente de Tiro $(2.49 .3,4.147 .4)$ assim como sua irmã, Europa (4.45.4). Dentre outros historiadores (ou mitógrafos/atidógrafos), sabe-se que Helânico de Lesbos compartilhava da mesma opinião de Heródoto e que Ferecides de Atenas advogava pela origem egípcia $^{69}$. Quanto a Tucídides, nenhuma informação é dada sobre o tema.

Eurípides, consequentemente, não estava diante de uma tradição unívoca a respeito de Cadmo. Na verdade, As Fenícias adotam o que Gomme (1913, p.61) chama de "Teoria Fenícia": isso implicava que, sendo Cadmo o fundador de Tebas, as origens da pólis eram bárbaras. De uma maneira geral, essa foi a posição do poeta no conjunto de sua obra. Fazer de Cadmo um fenício, portanto, foi uma escolha mitográfica do tragediógrafo que mostra um posicionamento concordante com a tradição de sua época.

\footnotetext{
68 Tradução de Ragusa (2014). O título do poema, contudo, é incerto, cf. Ragusa (2014, p.148).

69 Sobre Helânico, ver Gomme (1913, p.64). Há, porém, uma controvérsia sobre os dados de Ferecides, cf. Gomme (1913, p.47) e Edwards (1979, p.47).
} 
Sobre esse tópico não há inovação. O que dizer, então, a respeito da relação do poeta com a "mentalidade mítica" ( $i$.e racionalização e negação do $\mu v \theta \tilde{\omega} \delta \varepsilon \varsigma$ ) exposta acima? Ora, quanto ao primeiro ponto, é possível se tirar duas conclusões. A primeira, argumentum ex silentio, mostra a racionalização do motivo da chegada de Cadmo a Beócia, pois nenhuma menção é feita à intervenção divina, ou seja, ao rapto de Europa feito por Zeus. Contudo, a racionalização é preterida quando se menciona o matrimônio

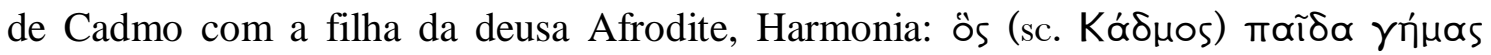

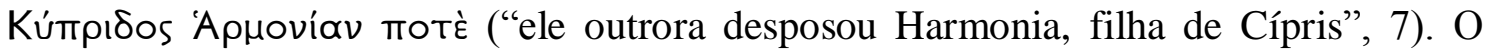
segundo estásimo repte esse informação, reforçando a presença do divino na história de

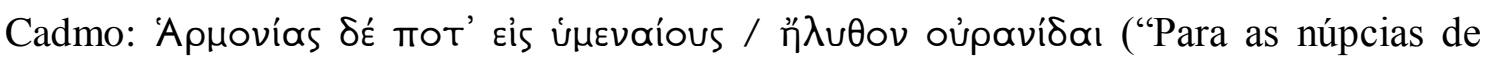
Harmonia os uranidas vieram então", 822-3). Por esse mesmo motivo, portanto, observa-se que tampouco o $\mu v \theta \tilde{\omega} \delta \varepsilon s$ está excluído do argumento dramático da peça.

Outra questão que é possível se vislumbrar a partir do primeiro estásimo é: a quem é atribuída a fundação de Tebas?

Embora As Fenícias não forneçam explicitamente resposta a essa questão, o gentílico “cadmeu” é utilizado diversas vezes para se referir à população de Tebas:

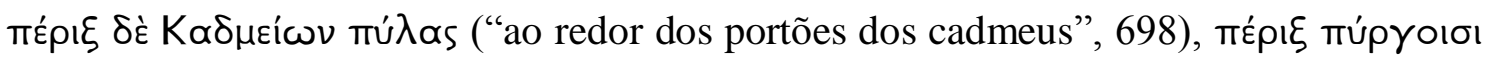

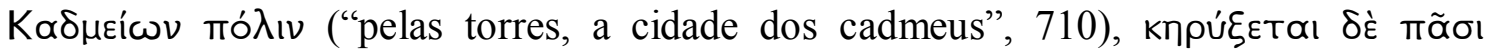

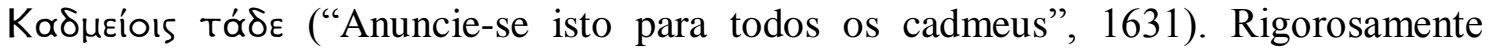
falando, porém, o gentílico não necessariamente se forma a partir do fundador da cidade. De fato, algo semelhante ocorre em Homero. Como se viu na introdução deste capítulo, a Odisseia (XI, 260-3) atribui a fundação de Tebas aos irmãos Zeto e Anfião, mas, mesmo assim, é utilizado aí também o gentílico "cadmeu” para se referir aos tebanos (Odisseia, XI, 275-6).

O segundo estásimo fornece, porém, um dado adicional: as muralhas e as torres

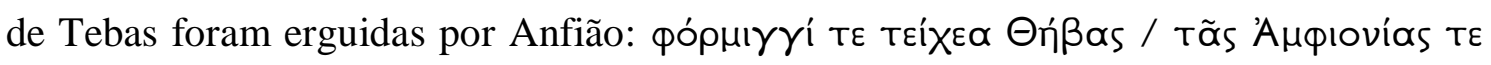
$\lambda$ úpas üாo múpyos ávéota ("ao som da harpa e das liras de Anfião ergueram-se a muralha Tebana", 823-4). Anfião, de fato, já havia sido mencionado por Antígone na theichoscopia: Aupíovos (...) / твíxєos ("a muralha de Anfião", 115-6). Mas quais implicações mitográficas se sucederiam de uma ou outra escolha?

Como visto acima, a história de Cadmo está impregnada de elementos divinos. Mitologicamente, o mesmo acontece para Zeto e Anfião: ambos são filhos de Antíope, 
que fora engravidada por Zeus ${ }^{70}$. Eurípides não explora esse detalhe, mas o mítico da história está presente no fato de a muralha ter se erguido pela música da lira de Anfião.

Determinar, porém, um ou outro como fundador traz detalhes significativos. As linhagens de Cadmo e de Zeto e Anfião mostram uma importante diferença: esta linhagem é autóctone (Antíope é filha do deus-rio beócio Asopo ${ }^{71}$ ), aquela, estrangeira. Se Eurípides não se importou em corroborar uma ou outra versão, como parece ter feito a respeito do nome de Jocasta, isso não diminui a influência do gênero da mitografia no texto de As Fenícias, conforme hipótese levantada neste capítulo. Antes, é de se supor que o mito de fundação de Tebas fosse, por natureza, duplo. Segundo Mastronarde (1994, p.388):

Tebas tinha um mito de fundação dual, sendo Cadmo o responsável pela seleção do sítio e pela origem das famílias reais (com ênfase em sua função militar), e os gêmeos divinos (como Rômulo e Remo), responsáveis pelo desenho e construção das muralhas que denotam uma pólis consolidada.

De fato, entre os contemporâneos de Eurípides, Ferecides (FGrHist 3 F 41d) propôs como solução uma dupla fundação para Tebas: primeiro Zeto e Anfião fundam a cidade, que é logo destruída e refundada por Cadmo. Segundo Amiech (2004, p.270), uma solução parecida é encontrada num escólio medieval, que relaciona Cadmo à fundação de Tebas, e Zeto e Anfião à construção das muralhas.

A origem de Tebas, portanto, tinha um duplo caráter: era ao mesmo tempo autóctone e estrangeira. Eurípides, ao silenciar sobre a fundação da cidade, de certo modo propala as duas versões. Segundo Kühr (2006, p.370), a riqueza do mito de Tebas residia exatamente nesse ponto:

Anfião e Zeto, contudo, foram considerados como meros construtores da muralha, restrita à região entre Tebas e o rio Asopo. Mas eles possuíam uma vantagem: sendo

\footnotetext{
${ }^{70}$ Ver testimonia iii da peça Antíope de Eurípides e Odisseia (XI, 261).

71 Odisseia (XI, 260). Segundo fontes tardias, porém, Antíope é designada como filha de Nicteu (Pausânias 2.6.1; test. iii de Antíope).
} 
descendentes de um rio, eles eram autóctones, e este era um critério muito importante para primordialidade. Cadmo em seu papel de fenício, porém, era um estrangeiro. Havia duas formas de se argumentar pela sua superioridade e sua ancestralidade: primeiro, o aspecto dos méritos culturais tornou-se progressivamente importante. Neste sentido, Cadmo era imbatível. Segundo, o episódio dos Espartanos, os semeados e terrígenos primeiros cidadãos de Tebas, ocupou uma feição preeminente dentro do mito de fundação. Por causa deles, Tebas podia ter ambos: raízes regionais e ligações "internacionais". Afinal, foi a adaptabilidade deste mito que garantiu seu sucesso e sobrevivência.

No segundo estásimo (784-833), o coro diversifica o teor de seu canto. Na estrofe (784-800), a narração mítica, que predominou no primeiro estásimo, é substituída por uma invocação a Ares que será comentada no capítulo 2. Somente na antístrofe (801-17) e no epodo (818-33) essa narração será retomada, ainda assim ela figurará mesclada em uma invocação pelo divino. Resumidamente, os tópicos míticos aí abordados são quatro: a história de Édipo e a Esfinge (antístrofe), da geração dos Semeados, do casamento de Harmonia e da música de Anfião (epodo).

$\mathrm{Na}$ verdade, a antístrofe traz um apanhado geral do que se viu narrado por Jocasta no prólogo (10-31) e do que será de novo relatado por Édipo no êxodo (1595614). Os versos do coro são (801-1):

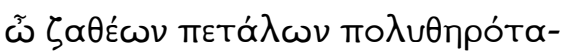

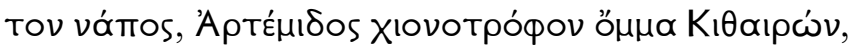

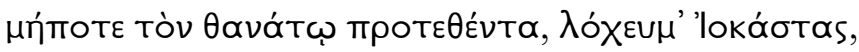

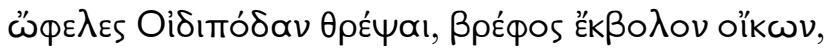

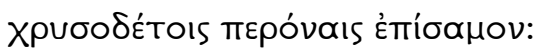

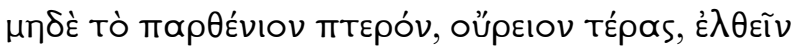

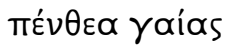

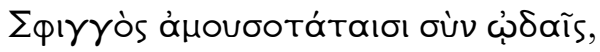
$807 \mathrm{bis}$

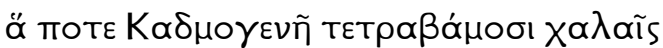




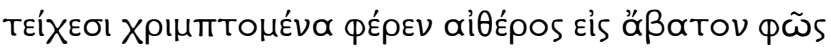

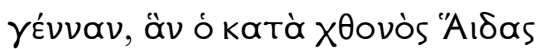

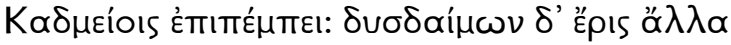

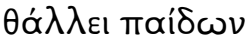

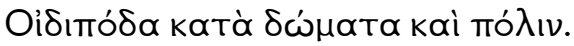

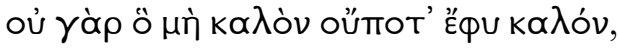

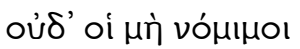

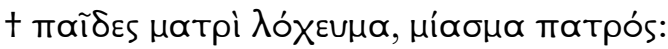

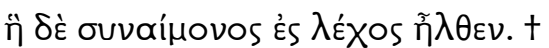

Ó bosque de folhas sagradas, o mais

Frequentado por bestas, olho de neve de Ártemis,

Citerão: que nunca o assinalado para a morte, Édipo,

Rebento de Jocasta, tu tivesses alimentado,

Inda bebê expulso de casa, cravejado em ouro!

805

Nem que a alada virgem Esfinge, monstro dos montes,

Tivesse vindo molestar esta terra

Com seus desentoados cantos,

807bis

Quando a quatro patas se aproximou

Das muralhas, lançando para a luz inacessível do Éter

A raça cadmeia: por Hades do subtérreo

Ela foi enviada aos cadmeus. Mas é outra desditosa

Éris, aquela entre os filhos,

Que cresce palácio e na cidade de Édipo.

Do que não é belo jamais vem o belo,

Nem dos ilícitos filhos,

Brotos da mãe, miasmas do pai:

Ela se deitou no leito de um consanguíneo. 
Note-se que aqui a narrativa é feita como coadjuvante de um outro discurso, ou seja, ela aparece dentro de uma súplica, no caso, do monte Citerão, que se exprime por

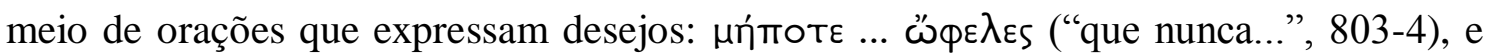
$\mu \eta \delta \dot{~(“ " n e m ~ q u e . . . ", ~ 806) . ~ N o t e-s e ~ i g u a l m e n t e ~ q u e, ~ a o ~ c o n t r a ́ r i o ~ d o ~ q u e ~ o c o r r e ~ e m ~ c e n a s ~}$ episódicas, todos os versos aqui são dactílicos (variando entre tetrâmetros, pentâmetros e hexâmetros). Segundo Mastronarde (1994, p.374) esse estilo métrico confere um efeito mais emocional, próprio do treno, ao relato.

A história, portanto, pode ser dividida em três partes: primeiro expõe-se o nascimento indesejado de Édipo (801-4), depois a vinda da Esfinge a Tebas (805-11), e, finalmente, a querela dos filhos nascidos do incesto de Édipo (812-17). De todo o exposto, o que figura propriamente como novidade mítica é a Esfinge, mencionada brevemente no prólogo por Jocasta (46), mas só agora posta em foco descritivo ${ }^{72}$.

A caracterização da Esfinge é ricamente detalhada. Assim, ela é assinalada como

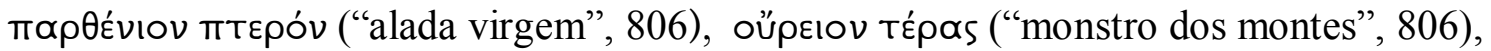

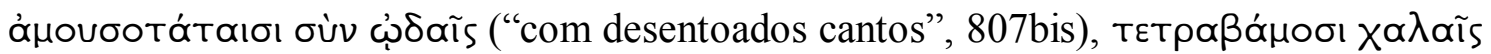
(“com quatro patas afiadas", 808). A proveniência da Esfinge é atribuída ao Hades (ó

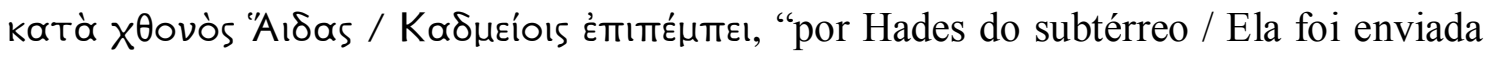
aos cadmeus", 810-11).

Neste ponto, é possível se esboçar uma resposta a questão levantada no início desta seção (sobre a junção mito-ação). A partir dos detalhes expostos nas antístrofe, pode-se visualizar um elemento mítico recorrente no conjunto narrativo da peça: assim

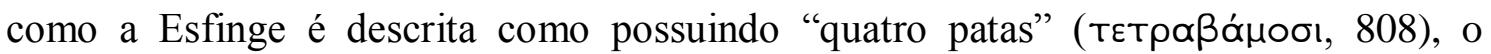
novilho que Cadmo seguiu até chegar ao terreno de Tebas é descrito de forma

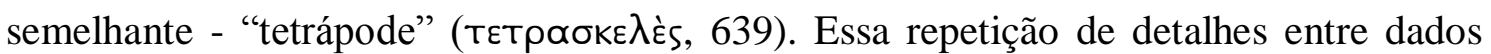
mitológicos pertencentes a épocas diferentes é um padrão mitológico geral assumido em As Fenícias: citem-se, por exemplo, os pares míticos do dragão de Ares sacrificado por Cadmo e o sacrifício de Meneceu; os Semeados se destruindo fratricidamente e os irmãos Etéocles e Polinices que se matam. Assim, nesta peça um determinado momento sempre é interpretado como decorrente de algum acontecimento do passado. Tudo está interligado, portanto, por meio do mito.

\footnotetext{
${ }^{72}$ E a narrativa sobre a Esfinge será retomada ainda uma vez mais no $3^{\circ}$ estásimo.
} 
O epodo, por sua vez, dará sequência ao que foi relatado na antístrofe. Ele pode ser dividido em três partes, em função do tema a que se atém. Assim, ele se introduz com a história do nascimento dos "Semeados" (818-21), cujas consequências posteriormente exercerão papel preponderante para o desfecho da luta entre Etéocles e Polinices. Depois, retoma-se o enlace de Harmonia e se apresenta edificação das muralhas de Tebas feita por Anfíão (822-7). Por fim, Io é apresentada como a geradora dos reis cadmeus ${ }^{73}$ (828-9). Assim, segundo essa divisão, propõe-se aqui dispor os versos do epodo da seguinte maneira:

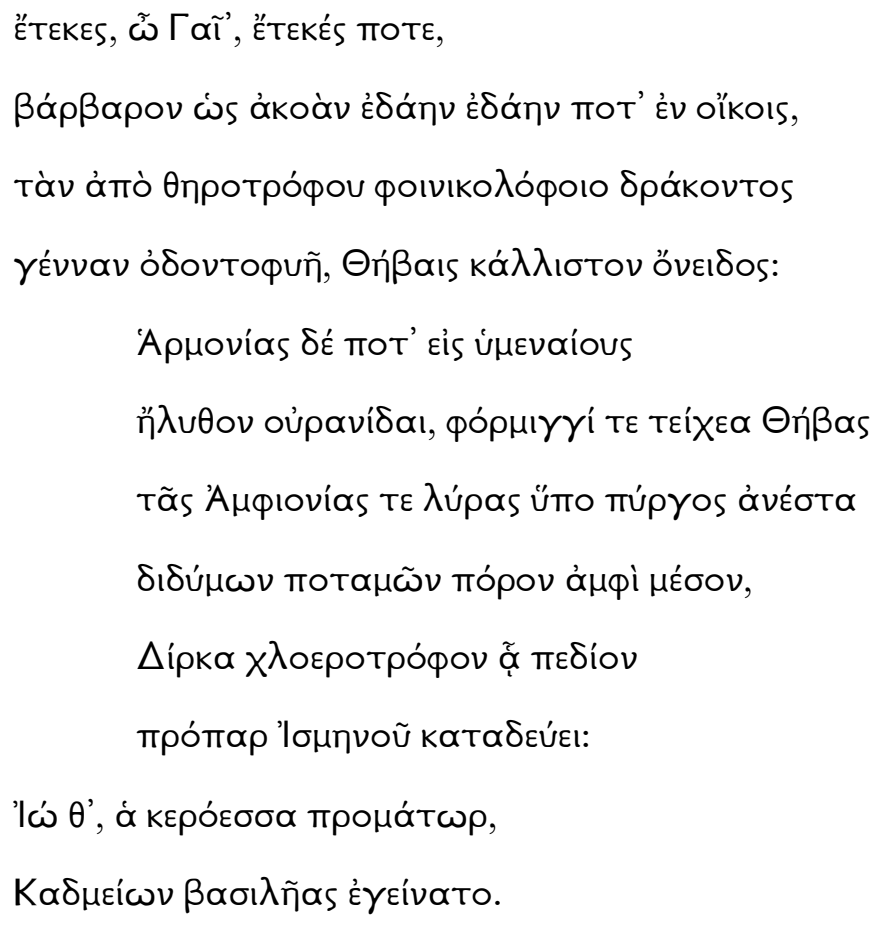

Criaste, ó Gaia, criaste outrora,

Como então aprendi em casa por bárbaro rumor,

A geração nata dos dentes da serpente de crista carmesim

Devorante de feras - belíssima desonra para Tebas.

Para as núpcias de Harmonia,

Os uranidas vieram então; ao som da harpa

E das liras de Anfião ergueram-se a muralha

Tebana e as torres entre gêmeos rios,

\footnotetext{
${ }^{73}$ Ver genealogia de Io na seção 1.2.
} 
Onde o Dirce rega o verdejante

Plano em frente ao Ismeno,

E Io cornuda, mãe primeira,

Gerou os reis dos cadmeus.

Como se vê, assim como a antístrofe deste estásimo, o epodo insere sua narrativa dentro da invocação à Terra. Ao contrário daquele canto, porém, ele se caracteriza pela repetição, isto é, ele, sobretudo, retoma histórias já mencionadas anteriormente: os Semeados aparecem primeiro estásimo (663-75), as núpcias de Harmonia, no prólogo (7) e a referência à Io, também no primeiro estásimo (677). A única novidade é o breve relato sobre as liras de Anfião e a construção da muralha de Tebas (mas não é informado quando isso se deu, se contemporânea ou posteriormente a vida de Cadmo).

Dessa forma, diante desta recorrência mitológica, propõe-se aqui denominar este fenômeno textual de "circularidade mítica". O estásimo seguinte, abordado em seguida, constituir-se-á mais um exemplo desta propriedade identificada aqui.

O $3^{\circ}$ estásimo (1019-66) é composto apenas de estrofe e antístrofe. Paralelamente a essa divisão, há apenas dois eixos temáticos: a chegada da Esfinge (estrofe) e de Édipo (antístrofe) a Tebas. Como se viu, a antístrofe do estásimo anterior trata do mesmo assunto. Não é necessária nenhuma divisão especial desses cantos, pois cada um apresenta um foco narrativo unidirecional:

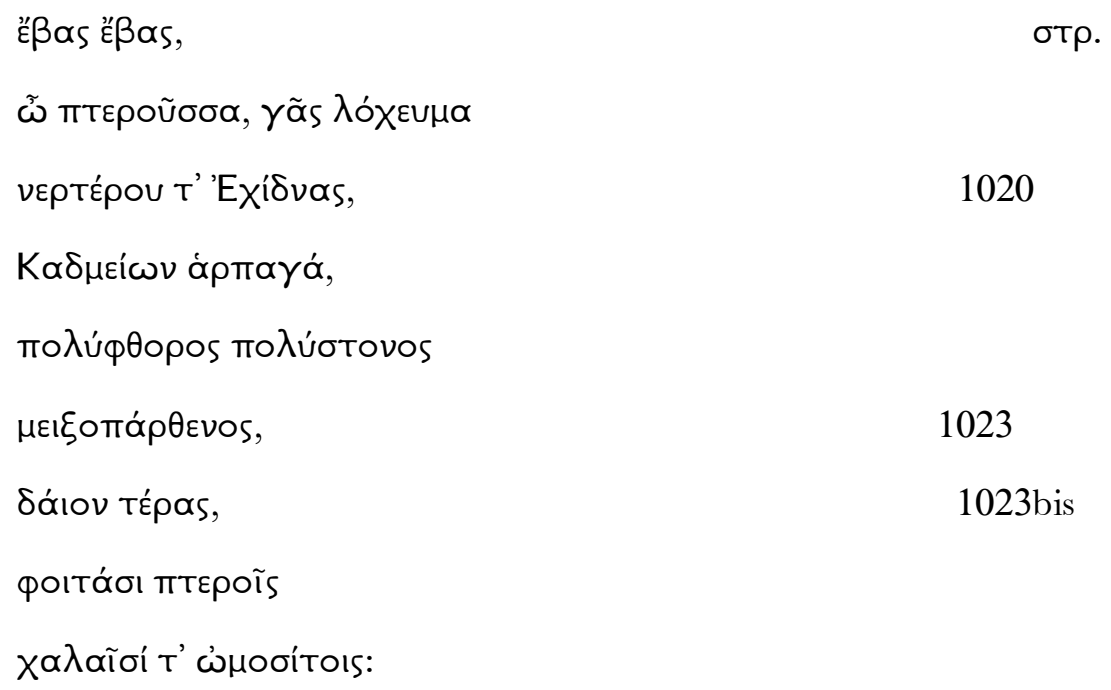




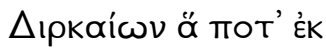

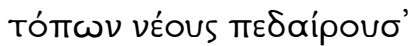

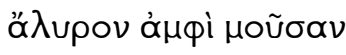

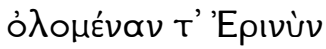

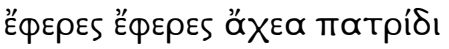

1030

申óvia: фóvios Ék $\theta \varepsilon \tilde{\omega} \nu$

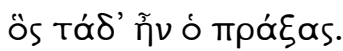

lá̉ $\lambda \varepsilon \mu \mathrm{O}$ I $\delta \grave{~ \mu \alpha T \varepsilon ́ p \omega \nu, ~}$

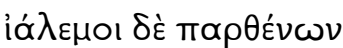

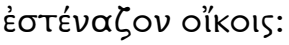

inıńıov ßoóv,

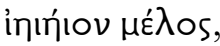

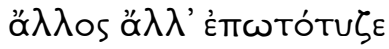

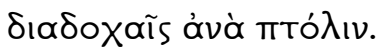

1038bis

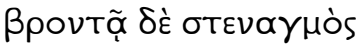

ảxớ T' ท̃र ömolos,

1040

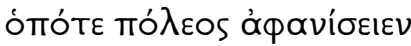

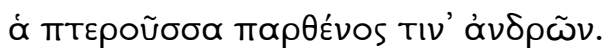

Vieste, vieste,

Ó alada, da terra

1019bis

Criatura e da ínfera Equidna,

1020

Dos Cadmeus a rapinante,

Ruína e gemido de muitos,

Virgem híbrida,

Mostro terrível

1023bis

De asas frenéticas e

Garras omófagas.

Ao redor do Dirce, outrora,

Arrebataste os jovens 
$\mathrm{Com}^{74}$ teu canto sem lira,

E com Erínia destrutiva,

Trouxeste, trouxeste à pátria

Dores letais. Letal entre

Os deuses quem isso realizou.

O chorar das mães,

O chorar das filhas

Ressoavam nos lares.

1035

Um grito de ai,

Um canto de ai

Um e outro exprimiam,

Sucessivamente, pela cidade.

A trovões os gemidos

E os brados se assemelhavam,

1040

Quando subtraía da cidade

A virgem alada algum dos homens.

A estrutura narrativa deste canto traz semelhanças com o gênero mitográfico. Embora o discurso esteja direcionado a um "tu" (presença do vocativo డ̃, 1019), o relato da atuação da Esfinge é ilustrado por verbos de ação. O quadro verbal, então, que

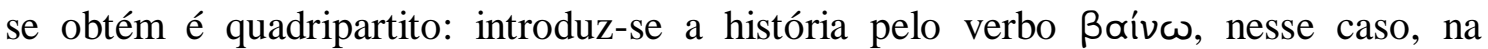

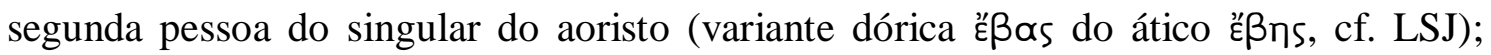

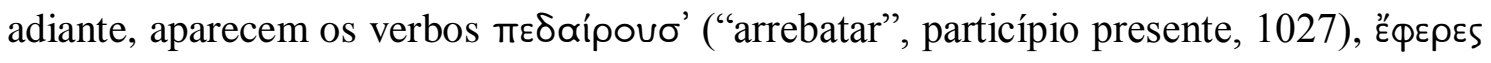

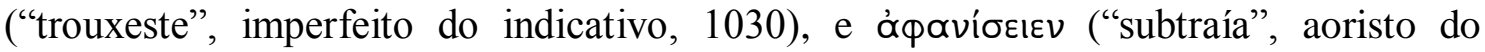
optativo, modo verbal requerido pela conjunção ómóte, 1041).

"Circularidade mítica", contudo, não quer dizer repetição ipsis litteris. Há, nesta parte, uma informação adicional. Se no $2^{\circ}$ estásimo apenas se informou quem enviou a

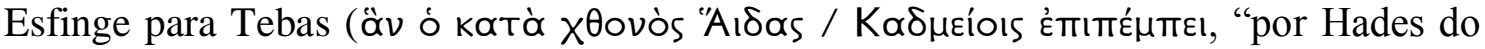
subtérreo ela foi enviada aos cadmeus", 810-11), aqui é feita notícia de sua genealogia:

\footnotetext{
${ }^{74}$ O ớupí aqui tem o sentido de "por causa de" ou “com", cf. Mastronarde (1994, p.439).
} 


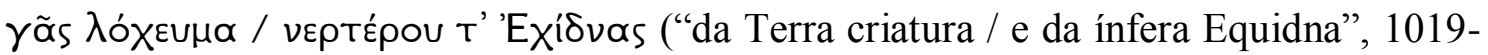
20).

A antístrofe (1043-53) apresenta uma estrutura semelhante (exclui-se o trecho final por se tratar de uma oração):

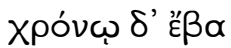

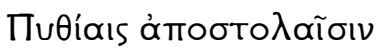

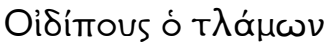

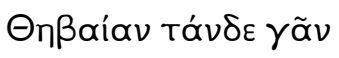

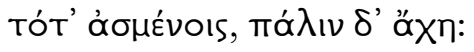

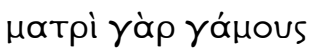

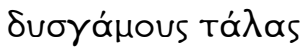

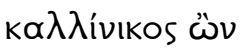

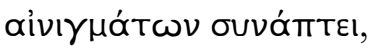

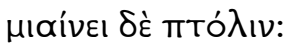

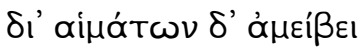

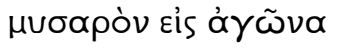

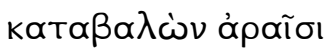

Em tempo veio,

Pelo mando da Pítia,

1043bis

O sofrido Édipo

A esta terra tebana,

Aliviada então, dolorida depois ${ }^{75}$.

Núpcias, insalubres

Núpcias, o sofrido,

1047bis

Vitorioso embora dos enigmas,

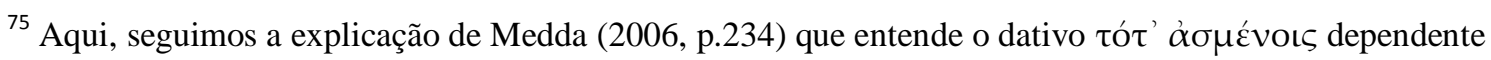
de $\varepsilon \beta \beta$ (1043). Esse dativo representaria, então, os cidadãos tebanos a quem Édipo salvara: "venne a loro che ne furono felici". Numa adaptação, traduzimos o dativo como se referindo a Tebas. Kovacs (2002) traduz como "at first bringing joy, then later grief".
} 
Estabelece com a mãe,

E macula a cidade.

1050

Ele põe seus filho, por atos de sangue ${ }^{76}$,

Em cruenta batalha,

Lançando-lhes maldições,

Há um paralelismo narrativo entre esses dois cantos: ambos iniciam-se seu relato valendo-se de uma variante do verbo ßaívw. A antístrofe, entretanto, possui um tom mais genuinamente narrativo, já que se exprime por meio de verbos na $3^{a}$ pessoa (não segunda, como na estrofe). Além disso, nota-se a preocupação de se situar

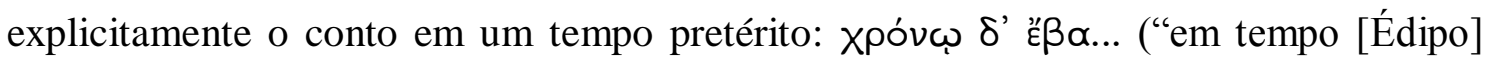

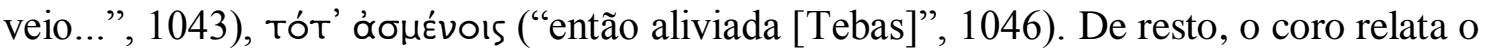
que já fora exposto por Jocasta no prólogo: Édipo desvenda o enigma da Esfinge (50, $1048)$, deita-se com a mãe $(53,1047)$ e amaldiçoa os próprios filhos $(67,1053)$.

Esta análise do último estásimo, portanto, corrobora o que vem sendo argumentado desde o início deste capítulo: Eurípides se apropria de elementos mitográficos, que se expressa fundamentalmente pelo que se chamou aqui de “circularidade mítica”, para elucidar a ação dramática por meio do mito. Em conclusão, é possível se afirmar que a feitura de As Fenícias revela influências de gêneros extradramáticos que, sem se sobreporem ao gênero próprio da peça, servem sobretudo para otimizar o efeito trágico, no final e em suas partes.

Para efeitos de recapitulação, os elementos que tornaram possíveis estes resultados podem ser diagramados da seguinte maneira:

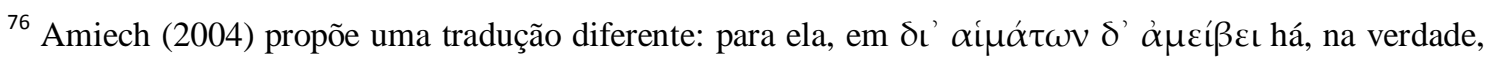
uma tmese, e o verbo seria $\delta 1 \alpha \mu \varepsilon i ́ \beta \varepsilon$. Assim, ela traduz esse verso por "il ajoute um crime aux crimes". Mastronarde (1994, p.444) entende como "acts of bloodshed", assim como Kovacs (2002). Note-se o

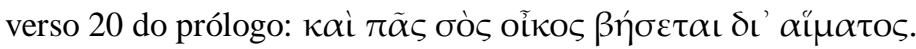




\section{Circularidade mítica:}

Cadmo, Dragão de Ares e Tebas - prólogo, $1^{\circ}$ estásimo, $2^{\circ}$ estásimo, $3^{\circ}$ episódio.

História de Édipo - prólogo, $3^{\circ}$ episódio, $3^{\circ}$ estásimo, êxodo.

\section{Junção mito-ação:}

Semeados - Etéocles e Polinices; Dragão de Ares - Meneceu. 


\section{CAPÍTULO 2:}

\section{AS FENÍCIAS E O PROBLEMA DO CULTO RELIGIOSO}

2.1 Introdução e breve histórico sobre o estudo mito-ritual na tragédia: em busca de uma análise imanente ou transcendente?

No capítulo 1, o foco do estudo foi o mito: procurou-se ali mostrar como a tragédia As Fenícias se valeu repetidamente de histórias pertencentes ao Ciclo Tebano como um todo a fim de se construir uma resignificação das partes míticas evocadas dentro da ação dramática. Pode-se dizer que o mito foi observado a partir de um plano horizontal: a narrativa mítica serviria como um suporte ao enredo da peça, ou seja, ela atualizaria eventos do passado no presente da trama. Desse modo, classifica-se aqui a análise de "horizontal", porquanto ela tenha considerado apenas elementos contíguos ao contexto à ação dramática.

A proposta do capítulo 2, por outro lado, diz respeito a uma análise "vertical" entre mito e tragédia. Neste sentido, a peça As Fenícias será observada pelo ângulo da performance teatral, o que, ao cabo, implica em se observar o teatro como "ritual". Essa abordagem, portanto, culminará em uma interpretação extradramática da tragédia grega. Elementos supratextuais, ou seja, elementos que estão além da estética teatral, ou que estão além da teoria dos gêneros literários, constituirão o objeto de estudo desta parte, analisados conforme metodologia explanada na seção 2.3. Em última instância, pode-se dizer, então, que o foco agora será a relação entre tragédia e religião grega.

Conforme brevemente mencionado no capítulo 1, a tragédia grega existia em dependência de um festival religioso dedicado a Dioniso. A inter-relação religiosa entre as peças e as Dionísias nem sempre são claras. Segundo Bierl (2009, p.267), grande parte da crítica moderna a respeito da tragédia grega tende a interpretá-la apenas em seu

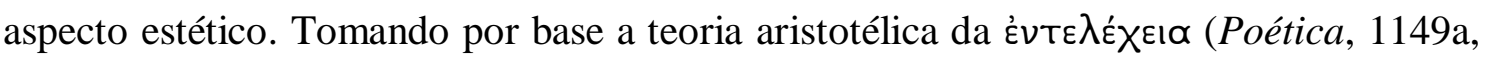
9 ff.), que vê a tragédia como evolução dos solistas de ditirambo, essa crítica, segundo Segal (1989, p.330) entende o gênero dramático "como uma forma desenvolvida por completo e como a joia entre as conquistas literárias que coroa a cultura da Grécia 
antiga", ou seja, desvinculado de ritual primitivo de que se originou. A isso o autor chama de "interpretação retrospectiva da tragédia".

É verdade que o gênero dramático na Atenas do tempo de Eurípides já estava bem estabelecido: a datação referente às primeiras representações trágicas em Atenas remonta ao século VI a.C, por volta do ano de $535^{77}$. O Sócrates de Platão, por exemplo, faz certos comentários que revelam o grande alcance que a tragédia tinha entre os atenienses: segundo ele, os tragediógrafos apresentavam suas peças sobretudo aspirando agradar o público ${ }^{78}$, que era "bastante numeroso", "mais de trinta mil gregos ${ }^{79, "}$

A abordagem teórica, porém, deste capítulo será outra. As Fenícias serão analisadas aqui tendo em primeiro plano sua relação com As Dionísias. O mesmo Sócrates mostra que aquela multidão que se reunia no teatro estava numa situação

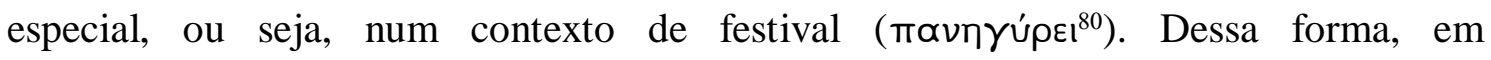
contraposição à visão retrospectiva, Seaford (1990, p.330) propõe a "visão prospectiva", que considera a tragédia "como uma criação que ainda se punha à frente da vasta cultura oral da Grécia arcaica" (ibidem). Como, então, entender As Fenícias dentro de sua ocasião de performance: pura ilusão teatral ou também ritual?

Como ponto de partida para a análise ritualística de As Fenícias, seguem as palavras de elaboração de um método interpretativo tragédia-ritual de SourvinouInwood (2005, p.302):

$\mathrm{O}$ público do século $\mathrm{V}$ a. $\mathrm{C}$ não compreendia a tragédia como experiência puramente teatral, uma unidade dramática abstrata, simplesmente emoldurando rituais, mas também como uma performance ritual; assim, etiologias, divindades e outros elementos religiosos não eram, para ela, simplesmente aparato teatral, mas estavam carregados de significação ritual; eles eram, em graus e sentidos diversos, parte da realidade religiosa da audiência ${ }^{81}$. (negrito nosso)

\footnotetext{
77 Tragédias também eram apresentadas nas Lenéias (festival também em honra a Dioniso). Segundo Wilson (2010, p.37), porém, o festival ático de maior relevo eram as Dionísias. Sobre datação das primeiras tragédias, ver West (1989).

${ }^{78}$ Platão, Górgias, 502c-d.

${ }^{79}$ Assim fala Sócrates acerca da encenação da peça de Agatão que ganhara o primeiro lugar no concurso

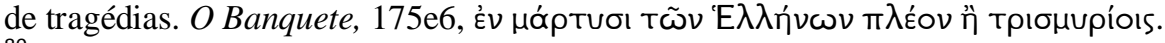

${ }^{80}$ Platão, A República, X (604e).

${ }^{81} \mathrm{O}$ intuito geral da obra de Sourvinou-Inwood (2005, p.303) é entender a tragédia grega de forma a mais próxima possível do modo como a audiência original a entendia.
} 
Ilustrativamente, pode-se ver aí as duas abordagens teóricas supracitadas: a "retrospectiva" se resume no que a autora chama de "experiência puramente teatral"; a "prospectiva" é exemplificada a partir da realidade ritual do teatro. A performance, diretamente ligada ao âmbito da oralidade, coaduna, portanto, o oral e o ritual. Assim segundo Segal (1989, p.348):

A tragédia, como a épica, desenha-se grandemente a partir da função da canção em uma cultura oral, como a expressão ritualizada de intensa emoção e como um modo de interação pessoal (...). Mas ao contrário da épica, a tragédia está em todo lugar impregnada com o fato de que ela é uma imitação de um ritual dentro de um contexto público ritualizado ${ }^{82}$.

Há muitas variantes, porém, possíveis de serem trabalhadas quando mito e ritual são postos em foco. "História da religião", "etiologia cultual" e "performance ritualística" são alguns exemplos de enquadramentos teóricos resultantes daquela relação. Uns caracterizam-se mais por propor uma análise imanente ao texto, ou seja, investigam elementos carregados de significação, qualquer que seja, apenas literariamente. Se o aspecto abordado, por exemplo, for o ritual, então determinado trecho de uma obra será marcado como a imitação de um ritual. Outros caracterizam-se mais por propor uma análise transcendente do texto. Nesse caso, determinado trecho de uma obra não será apenas a imitação, mas a realização stricto sensu de um ritual. Logicamente, a "análise transcendente" só é cabível dentro de uma manifestação "poética" oral.

Aqui, As Fenícias serão investigadas segunda a abordagem chamada "performance ritualística", ou seja, de acordo com o padrão de uma "análise transcendente". Assim, determinados elementos textuais dessa peça serão transpostos ao

\footnotetext{
82 Note-se, contudo, que Segal não está inteiramente de acordo com as visões de Sourvinou-Inwood (2003, 2005, 2011) e Bierl (2009), que será alvo de consideração abaixo. Como ressalva a esse trecho, ele diz que "não entende que as peças constituam um ato de adoração a Dioniso em um aspecto formal". O propósito de se mencionar Segal é que ele confirma o fato de a tragédia ser uma celebração religiosa e trazer numerosamente elementos ritualizados.
} 
nível da performance, a fim de se observar se, de fato, o ritual é "presentificado" no momento de sua performance como uma ato religioso per se, e não está apenas sendo mimetizado dentro de um gênero literário ${ }^{83}$.

Nomes proeminentes desse tipo de análise são Bierl, Sourvinou-Inwood e Graf. Bierl (2009, p.21), por exemplo, afirma que o coro no drama antigo (principalmente na comédia) é amplamente ritual. Graf (2005, p.111) está de acordo, centrando-se, por sua vez, sobretudo no caráter ritual do coro trágico. Como síntese dessa linha teórica, considerem-se as seguintes palavras de Sourvinou-Inwood (2003, p.292): "o coro trágico também era percebido como um coro de Dioniso no aqui e no agora [espaçotempo da encenação], e as tragédias eram percebidas pelos espectadores antigos como projetadas como um ritual no momento presente ${ }^{84,}$.

Fazendo um breve histórico sobre os estudos que abordem a tragédia grega em seu aspecto religioso, vê-se que aqueles dedicados à "performance ritualística" são mais recentes. De um modo geral, no século XX as análises "retrospectivas" e "imanentes" foram preponderantes. Aplicados aos estudos clássicos, a abordagem transcendente, pode-se dizer, é bastante recente, como será visto a seguir.

Quando Winnington-Ingram (1954), analisando dramas de Ésquilo e de Sófocles, pretende estudar qual seria "a função religiosa que a tragédia estava peculiarmente designada a realizar" ${ }^{85, ", ~ " h i s t o ́ r i a ~ d a ~ r e l i g i a ̃ o " ~ e ~ " e t i o l o g i a ~ c u l t u a l " ~}$ formaram o eixo teórico de seu estudo. Dentro do conjunto de dramas que constituíram seu objeto de estudo, o autor observa (1) qual são as a relação possíveis, dentro dos textos, de se fazer entre os deuses "ctônicos" e "urânicos" ( $\chi$ Өóvııı e oúpóvioı), e (2) como é possível criar analogias entre tragédias (no caso, a trilogia Oresteia) e cultos ("o

\footnotetext{
${ }^{83}$ Ver Easterling (1988). De início, vê-se uma análise que se centra nas intersecções entre o ritual e o drama. Resumidamente, seu artigo trata da maneira pela qual os tragediógrafos se utilizavam da linguagem ritual e da ação ritual como temas e como efeitos dramáticos para suas peças. Até aí, tem-se um exemplo claro do que seria a análise "imanente". O foco teórico, porém, se altera quando a autora atribui um caráter ritualístico real para ações rituais encontradas em algumas tragédias. Segundo a autora, portanto, a parte final na peça Eumênides não apenas apresenta dramaticamente um ritual, mas se torna realmente um ritual ${ }^{83}$. Eis um caso típico de uma "análise transcendente", pois a peça ultrapassaria os limites do gênero dramático para, então, se tornar um ato religioso.

${ }^{84}$ Original: "Furthermore, since, as we saw, the tragic chorus was also perceived as a chorus of Dionysos in the here and now, tragedies were perceived by the ancient audiences as shot through by present-day ritual". Adotamos essa conclusão de Sourvinou-Inwood como premissa para desenvolvimento argumentativo diferente do da autora: a partir dessa premissa, ela irá argumentar que a epifania dos deuses no teatro era percebida uma "séria representação do divino", ibidem.

${ }^{85}$ Winnington-Isgram (1954, p.16).
} 
estabelecimento de um culto ateniense ou um festival ateniense $\left.{ }^{86,}\right)$. Em nenhum momento é ambicionado relacionar os trechos de caráter religioso com a performance dessas peças no festival em que foram encenadas. Mais tarde, Mcdermott (1991, p.123) notará como tal atitude crítica, i.e. de se associar questões míticas de uma tragédia a questões de práticas cultuais, tornara-se recorrente nos estudos helenísticos.

Na verdade, é justamente no século XX que surge a "escola de Cambridge de mito e ritual" ("Cambridge school of myth and ritual"). Era objetivo dessa escola explicar o mito como um produto dos rituais, e sua influência nos círculos helenísticos foi imensa: como um de seus principais representantes cite-se, por exemplo, o nome de Walter Burkert ${ }^{87}$. Uma das principais características dessa escola era relacionar alguma narrativa mítica a um rite de passage. Em suma, para se compreender integralmente um mito, preconizava a escola, ele deveria ser analisado em seu contexto ritualístico.

Especificamente com relação ao gênero trágico, intentou-se elaborar um padrão ritualístico que evidenciasse o caráter dionisíaco de todas as tragédias. Esse padrão, porém, tomava por base uma "análise imanente" ao texto. Assim, de acordo com Friedrich (1996, p.260), Gilbert Murray (1866-1957) teria identificado em todas as tragédias um arquétipo dionisíaco que simbolizaria a morte e renascimento de Dioniso. Esse arquétipo, por sua vez, recorria unicamente ao enredo das peças que teriam o

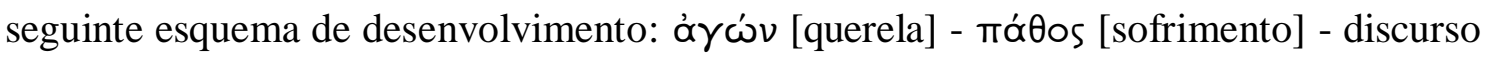

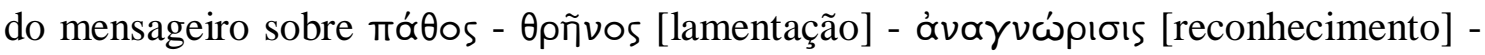
epifania. Desse modo, o protagonista das tragédias seria sempre Dioniso, mesmo que aparecendo sob disfarce ${ }^{88}$ (Prometeu, Édipo, Agamenão, etc.).

Ainda segundo Friedrich (1996, p.261), a tentativa de Murray de encerrar todas as tragédias naquele esquema ritualístico, porém, teria sido desmantelada por outro helenista britânico, Pickard-Cambridge (1873-1952). As ideias dessa escola, então, de maneira geral, caíram no esquecimento e, posteriormente, foram tachadas de

\footnotetext{
${ }^{86}$ Winnington-Isgram (1954, p.23).

${ }^{87}$ Ver discussão e histórico sobre essa escola em Baragwanath (2012, p.16) e em Kowalzig (2007b, pp.13-23).

${ }^{88}$ Por causa disso, tal escola também teria sido alcunhada como a crítica màv mpòs tòv $\triangle$ ióvuoov ("tudo

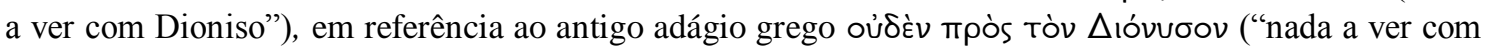
Dioniso"), cf. Friedrich (1996, p.265). Nietzsche, no seu livro O nascimento da tragédia, também esboçara uma ideia semelhante: "Mas com a mesma certeza cumpre afirmar que, até Eurípides, deixou Dioniso de ser o herói trágico, mas que, ao contrário, todas as figuras afamadas do palco grego, Prometeu, Édipo e assim por diante, são tão somente máscaras daquele proto-herói, Dioniso".
} 
"reducionistas". Kowalzig (2007b, p.21), porém, mostra que os estudos clássicos jamais se desvencilharam completamente da escola de Cambridge ${ }^{89}$.

Independentemente dessa escola, porém, a tragédia sempre suscitou questões relacionadas à religião e seus cultos e rituais. Como síntese, Graf (2005) divide os estudos helenísticos acerca desse tema em três grupos:

1) Debate a respeito da origem do drama a partir do ritual. Essa vertente teria se iniciado com os apontamentos de Aristóteles na Poética (IV, 1149a, 9 ff.) sobre como a tragédia teria sido uma evolução dos ditirambos e a comédia dos cantos fálicos

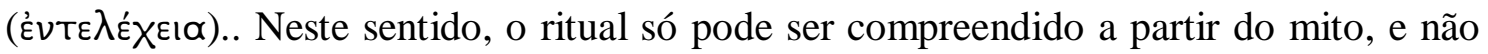
propriamente a partir do ritual: “o estágio no qual o ritual já havia se unido ao mito e, assim, incorporara uma trama narrativa, e no qual estabeleceu uma separação dos participantes em atores e espectadores ${ }^{90 "}$. Dessa forma, o drama não seria "ritual", embora houvesse resquício de seu caráter ritual original. Em seu último estágio, a evolução do ritual em drama daria origem ao "drama literário" ${ }^{91 "}$. Tal debate continua vivo até hoje: Burkert (2001), por exemplo, trabalha com a análise filológica do termo

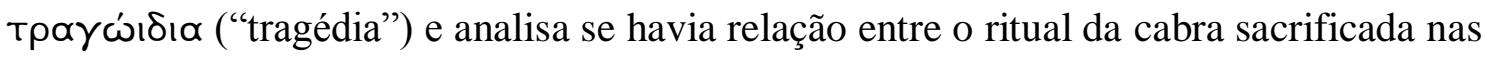
Dionísias e as encenações dramáticas

2) Debate que trata o ritual como drama. Nesse caso, a encenação de uma peça seria vista apenas como uma parte constitutiva de um festival que, este sim, seria ritualístico. Segundo Graf (2005, pp. 109-110), tal debate se inicia no século XIX e se prolonga até metade do século XX, quando se esgota; notórios representantes dessa linha teórica seriam Hermann Usener (1834-1905), que entendera como sinônimos as palavras gregas

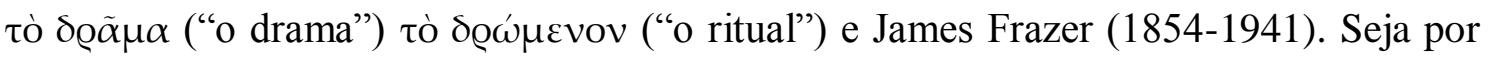
causa de sua metodologia, seja por causa de suas suposições básicas, nenhuma dessas teorias sobreviveu ${ }^{92}$.

3) Debate que trata o drama como ritual. Tendo legado a terminologia "drama ritual" da segunda vertente, essa linha teórica surge nas décadas de 1960 e 1970 com

\footnotetext{
${ }^{89}$ Seaford (1996), por exemplo, tem como ponto central de sua discussão analisar o que a tragédia possui de dionisíaco. Igualmente para este autor, haveria um padrão segundo o qual todas as tragédias construiriam seus mitos: todas elas remeteriam ao padrão narrativo da história de Dioniso.

${ }^{90}$ Friedrich (1996, p.271).

${ }^{91}$ Friedrich (1966, p.272): seria por esse motivo que já na antiguidade começou a se questionar o que "a tragédia tinha a ver com Dioniso".

${ }^{92} \operatorname{Graf}(2005$, p.110).
} 
experimentos teatrais que enfatizavam o caráter ritual do drama. Antropólogos como Turner e Schechner-Appel publicaram importantes estudos nas décadas de 1980 e 1990. No caso dos estudos helenísticos, o foco se firmou na performance de tragédias e comédias, e Graf (2005, p.111) cita Anton Bierl como notório representante dessa escola. Segundo Rehm (2012, p.413), por exemplo, o coro trágico não só exerceria, durante a encenação de uma tragédia, um papel dramático, mas também extradramático: “audiência da tragédia no século $\mathrm{V}$ a.C percebia os coros trágicos como um grupo de performers ritualísticos em seu próprio direito, para além de seu papel em qualquer uma das tragédias ${ }^{93 "}$ (negrito nosso).

\subsection{Atos religiosos em As Fenícias}

A religião exerce um papel preponderante dentro da ação dramática de $A s$ Fenícias. A peça apresenta uma quantidade considerável de "atos religiosos" - por "ato religioso" entenda-se toda enunciação verbal que tem como destinatário alguma entidade sobre-humana, ou seja, uma divindade ( $\theta \varepsilon o ́ s)$ ou um nume ( $\delta \alpha i ́ \mu \omega v)$. Ao todo, encontram-se vinte e duas orações ou invocações (considerando-se também aqueles narrados pelo mensageiro). De uma forma ou de outra, os acontecimentos dramáticos da história de Tebas aí figurada estão todos conectados a partir de questões religiosas.

Levando-se em conta, por ora, os atos religiosos proferidos apenas por personagens individuais (as falas do coro, embora elencadas, serão analisadas somente na seção 2.4), pode-se enumerá-los, por ordem de aparição, da seguinte maneira:

Jocasta invoca o Sol (1-3);

Jocasta faz prece a Zeus (85-7);

Antígone invoca a Hécate (109-111);

Antígone invoca Selene (175-6);

\footnotetext{
${ }^{93}$ É preciso constatar, porém, que há estudos que tomam uma linha teórica oposta ao que se viu acima. Tal é o caso, por exemplo, de Scullion (2002), Gould (2001, pp. 378-414) e Silk (1996, pp. 217-243).
} 
Antígone invoca Nêmesis e os "trovões de Zeus" (182-4);

Antígone faz duas orações a Ártemis (151-3, 190-2);

Jocasta faz prece a um deus (TIS $\theta \varepsilon \tilde{\omega} v, 467-8$ );

Coro faz prece aos deuses ( $\theta \varepsilon o i ́, 586-7)$;

Polinices invoca deuses pátrios (604-8);

Polinices se dirige a Apolo (631);

Coro faz prece Épafo, Perséfone e Deméter (676-689);

Etéocles faz prece à Precaução (782-3);

Coro invoca Ares (784-800);

Coro invoca Citerão (801-17);

Coro invoca Terra (818-832);

Coro invoca Esfinge (1018-42);

Coro faz prece a Palas (1060-65);

Capaneu desafia Zeus (1175);

Coro invoca Zeus e Terra (1290);

Polinices faz oração a Hera (1365-8);

Etéocles faz oração a Palas (1373-6);

Coro invoca Vitória (1764-66);

O cerne do problema que a As Fenícias encenam é de cunho religioso: Cadmo matou o dragão do deus Ares, Tebas foi o local de nascimento do deus Dioniso, Laio desobedeceu ao oráculo de Apolo e Édipo amaldiçoou os filhos Etéocles e Polinices. Em certo sentido (i.e. dentro da perspectiva da "análise imanente"), é possível interpretar os "atos religiosos" como a expressão da tentativa dos personagens do drama 
de solucionarem o problema de Tebas. Na verdade, de acordo com Sourvinou-Inwood (2003, p.285):

As Fenícias possuem uma densidade ritual significativa e outras referências religiosas, embora elas não ocorram de forma uniforme ao longo da peça. Tal organização de ritual é interligada com uma problematização da religião, a exploração de uma variedade de fatores religiosos, incluindo lealdade aos ancestrais, deuses locais e a dimensão religiosa de se atacar a própria cidade; a questão do sacrifício humano; e o complexo nexo de noções envolvendo as Erínias, o cumprimento de maldições, a noção do destino pré-ordenado e do papel do oráculo délfico.

O centro dramático de As Fenícias, aquilo que confere o caráter trágico e onde os personagens buscam o alívio de tensão, portanto, manifesta-se por meio de elementos do universo religioso. Em outras palavras, ao menos dentro da ação dramática a religião é preponderante. Assim, encontrar uma unidade temática ou estrutural nos atos religiosos referidos acima constitui o primeiro passo para se entender o possível caráter ritual e extradramático da peça. Para isso, propõe-se o seguinte sistema classificatório acerca dos discursos religiosos: a)invocação e oração de intercessão e b)oração apotropaica $^{94}$.

A) Invocação e oração de intercessão:

De acordo com Pulleyn (1997, p.132), toda oração contém, por sua natureza, uma parte invocativa. As Fenícias, como se viu na listagem acima, apresenta uma uma grande quantidade de discursos invocativos, isto é, discursos direcionado a uma divindade que contenha apenas o chamamento a ela, carecendo de qualquer pedido. Por não se tratarem exatamente de orações, convencionou-se aqui chamá-los apenas por “invocações”. Serão analisados a seguir duas "invocações” que servirão de paradigma

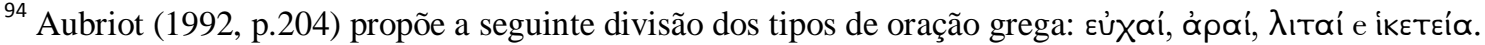
Para os fins desta dissertação, os grupos propostos acima parecem mais apropriados. Referências ao sistema de Aubriot serão feitas quando julgadas necessárias. Ver comentário à divisão de Aubriot em Pulleyn (1997, p.63).
} 
para as outras ocorrências desse tipo ao longo do texto. Essencialmente, cada invocação modula a tonalidade da ação dramática segundo a natureza de quem a profere e do deus a quem se destina.

A abertura da peça As Fenícias, de fato, é uma invocação, ou, segundo Amiech (2004, p.235), uma“apóstrofe solene”, feita por Jocasta à divindade Sol ${ }^{95}$ (1-3):

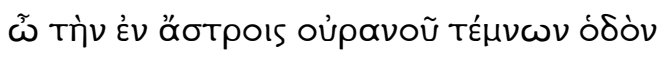

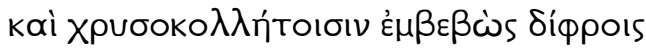

"H
}

Ó tu que, entre estrelas, avanças na estrada

do céu firmado num carro de áureos relevos,

Sol, tu que orbitas tua chama com céleres corcéis.

Nesse caso, o tom do discurso se marca como lúgubre sobretudo por ser proferido por Jocasta - segundo Polinices, ela está “com a cabeça raspada e vestida em trajes negros” (372). O Sol, nesse caso, está relacionado, como nota Mastronarde (1994,

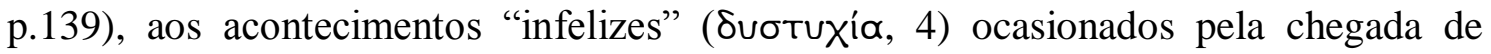
Cadmo à Beócia (5-6). Por si só, porém, não é possível depreender nenhum caráter moral para a divindade do Sol. De acordo com a tradição hesiódica, Sol é descendente dos titãs Hipérion e Téia e irmão de Lua e Aurora (Teogonia, 371-4). A ele não é atribuído aí uma atuação benévola ou malévola, mas na peça de Eurípides Jocasta o relaciona a um dia de mau agouro. Mastronarde (1944, p.142) observa que invocações são comuns no início dos prólogos euripidianos (Alceste, Andrômaca, Electra) e que elas estabelecem o tom (nesse caso, lúgubre) da peça.

Essa invocação, assim caracterizada, confere, portanto, desde início a toda peça um coloração ambígua: ao mesmo tempo que o Sol representa a luminosidade, para

\footnotetext{
95 Feita a ressalva de suspeita a respeito de genuinidade dos dois primeiros versos. De maneira geral, porém, comentadores tendem a admitir a possibilidade de serem os versos realmente euripidianos. Ver Amiech (1998) e Mastronarde (1994).
} 
Tebas, porém, ele marca o dia originário de todo sofrimento. Esperança e desgraça então serão os motes do desenrolar da história dessa cidade. Se Jocasta menciona, de início, um acontecimento infeliz, o seu monólogo se fecha com uma oração a Zeus que confere um tom esperançoso à peça:

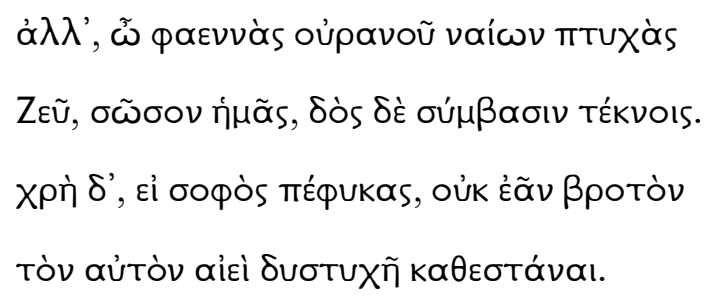

Mas ó tu que habitas as brilhantes alturas do céu,

Zeus, salva-nos, dá concórdia aos meus filhos.

É preciso, se és por natureza sábio, não permitir que o mesmo mortal esteja sempre na desgraça ${ }^{96}$.

A estrutura da parte que envolve apenas a invocação, como se pode observar, é semelhante à invocação ao Sol. $\mathrm{O}$ ato de chamar a divindade se caracteriza pelo vocativo $\tilde{\omega}$ seguido do nome do deus. A caracterização da divindade também apresenta

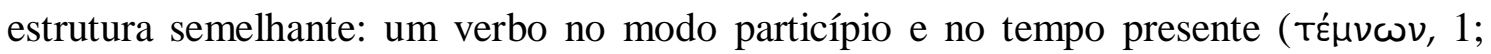
vaíwv , 84). Podlecki (1962, p.357) observa que a invocação luminosa feita a Zeus ("tu que habitas as brilhantes alturas do céu”, 84) remeteria ao Sol invocado anteriormente, caracterizando um símbolo da justiça, ou da verdade. Independentemente dessa suposta carga simbólica, Amiech (2004, p.258) nota que essa invocação é feita à maneira

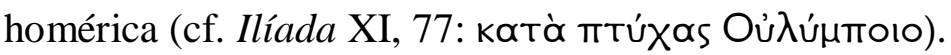

Assim, portanto, se abre e fecha o monólogo de Jocasta. Estruturalmente, Craik (1988, p.173) nota que esse movimento (o abrir-se e fechar-se de uma determinada parte com uma oração) pode ser chamado de "composição aneliforme" ("ringcomposition”). Essa composição aneliforme, porém, pode ser estendida também ao plano temático, já

\footnotetext{
${ }^{96}$ Sobre discussão a respeito do tratamento euripidiano dos deuses, ver Amiech (2004, pp. 258-9).
} 
que tudo obedece ao padrão alternado de "esperança e desgraça", conforme se vê no esquema abaixo:

Esperança - guerra se finda, jocasta espera salvar os filhos.

Desgraça - filhos se matam.

De fato, pode-se identificar nas duas preces destacadas acima um mesmo teor religioso. Por "mesmo teor", considerem-se as palavras de Mastronarde (1994, p.165) a respeito dessas orações:

A invocação a um deus em sua caracterização remota e eternamente brilhante marca uma intensificação do páthos, e referências a tal caracterização intensificam a natural dúvida humana a respeito da disposição divina de intervir e contrastam efetivamente com o escuro imediatismo do sofrimento humano.

Desse modo, Mastronarde classifica tais orações como "vãs" porque a intenção delas é fazer o poder divino resolver as disputas humanas de uma forma amigável. Tal é a intenção da oração que Jocasta faz no primeiro episódio, antes da contenda verbal entre Polinices e Etéocles (467-8):

KpITìs $\delta \varepsilon ́$ TIS

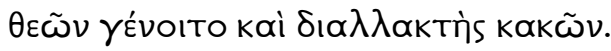

Que um dos deuses

Seja juiz e mediador dessas ofensas.

Conforme convencionado por Pulleyn (1997, p132), esse pedido de Jocasta não é estritamente uma oração. Apesar disso, esse enunciado se relaciona com o plano 
divino por expressar o desejo de que algum dos deuses intervenha na sua atual situação. O caráter suplicante, portanto, é evidente. Interessa notar ainda que essa súplica não se endereça a um deus específico. Que um dos deuses se torne juiz (kpıtìs) e mediador

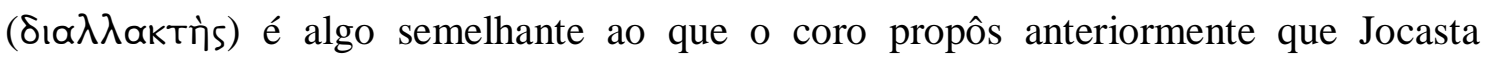

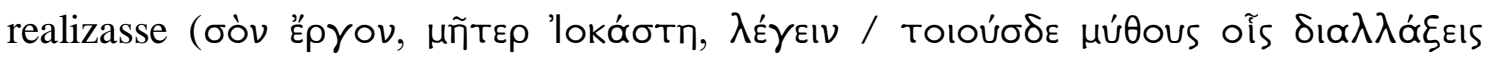
TÉkva, "A ti, Jocasta mater, cabe falar / aquelas palavras que reconciliarão os filhos", 444-5).

Outra marca da religiosidade de As Fenícias diz respeito ao gênero dos personagens que oram: em sua maioria, são mulheres. Excetuando-se o coro, que tem sua identidade estabelecida por um grupo, Antígone é a responsável pelo maior número de orações feitas, todas elas pronunciadas no prólogo. Curiosamente, os deuses a quem ela se dirige são todos igualmente femininos: Hécate (109-11), Selene (175-9), Nêmesis (e os "trovões de Zeus", que não são propriamente divindades, 182-189), e Ártemis (151-3, 190-2).

A invocação à Hécate é enunciada no inicío da teichoscopia. Ela precede, na verdade, o cerne da referida passagem, ou seja, a descrição que o preceptor de Antígone faz de todo o exército argivo que chega para atacar Tebas. Nesse sentido, portanto, pode-se dizer que, assim como ocorre no monólogo de Jocasta, também a teichoscopia é introduzida por um ato religioso e, como se verá adiante, é fechada por outra prece, retomando a "composição aneliforme" de Craik (1988) vista acima. Esta invocação será analisada no tópico das orações apotropaicas.

Depois da invocação à Hécate, Antígone se dirige a outra divindade feminina, Ártemis. Se a invocação a Hécate se posiciona no início da teichoskopia, essa oração se situa temporalmente na metade da exposição do preceptor de Antígone acerca dos soldados argivos, pois que é feita após a nomeação e descrição de três guerreiros inimigos (sendo sete no total). Os versos são (151-3):

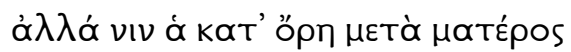

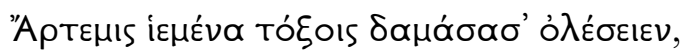

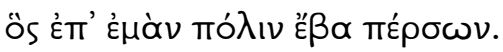


Que Ártemis das montanhas, com sua mãe,

domine-o e o perca com sua flechas,

ele que veio destruir minha cidade.

Essa oração a Ártemis ${ }^{97}$ constitui, igualmente, uma imprecação contra Partenopeu. Assim, aqui se vê outra face de Antígone: enquanto de início ela foi apresentada como "ilustre rebento da casa paterna" (88), mostrando-se como a menina que precisa da autorização de sua mãe para deixar seus aposentos (89-91), agora ela manifesta seus sentimentos mais agressivos. Desse modo, por meio da religiosidade das personagens, é possível se traçar aspectos de sua personalidade e de suas atitudes. Aqui Antígone mostra sua face hostil. Acima, viu-se como Jocasta roga aos deuses o que foi proposto especificamente para ela fazer.

Mais notável, porém, é a contraposição que se pode fazer entre Jocasta e Antígone, repetindo-se o jogo de ambiguidades da peça também nos atos religiosos dos personagens. Se, como visto acima, aquela se dirigiu inicialmente ao Sol, esta se dirige à Lua, ou Selene. Ela é proferida depois da descrição de Anfiarau, o penúltimo guerreiro mencionado pelo preceptor. Os versos são (175-8):

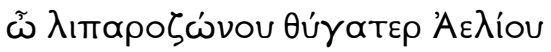

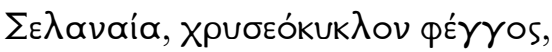

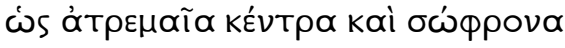

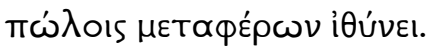

Ó progênie do Sol de luzidia cintura,

Lua, luz de círculo dourado,

\footnotetext{
${ }^{97}$ Amiech (2004, p.276) explica que a imprecação foi rogada em nome de Ártemis pois Atalante, a mãe de Partenopeu mencionada no verso precedente, é uma ninfa que tem essa deusa por patrona. Ártemis, por

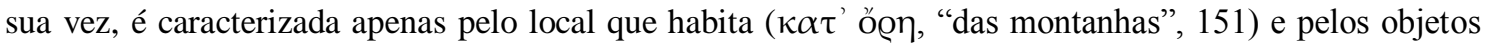

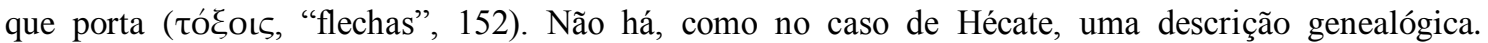
Segundo Hesíodo (Teogonia, 918), contudo, sabe-se que Ártemis era filha de Leto (descrita na peça como mãe de Hécate, 110).
} 
com calma e controle a vergasta

nos potros ele aplica, retifica sua rota.

É construída aqui uma genealogia peculiar: Selene é apresentada como filha do Sol (175), embora na Teogonia (371) ela apareça como sua irmã. Essa particularidade genealógica reflete a a relação parental entre quem ora e a quem a oração é destinada: de uma lado tem-se o par dos pais, Jocasta-Sol, do outro, dos filhos, Antígone-Selene. Além disso, note-se que Jocasta invoca apenas divindades masculinas, ao contrário de Antígone, que invoca somente as femininas e virgens - outro aspecto que se harmoniza com a natureza de Antígone. Eurípides dispõe então, por meio de atos religiosos, uma rede de contrapontos que permeiam toda a peça.

B) Oração apotropaica:

Por definição, oração apotropaica é toda e qualquer oração que visa anular ou afastar um mal. Ela pode conter um sua estrutura, como a oração de intercessão, uma súplica, mas há casos em que apenas a nomeação de uma divindade confere caráter apotropaico ao ato religioso. Em As Fenícias há uma ocorrência de uma "invocação apotropaica": trata-se da já mencionada invocação à Hécate, situada na abertura da teichoskopia.

Segundo Mastronarde (1994, p.183), invocações à Hécate por si só têm um forte caráter apotropaico. Os versos da invocação são (109-111):

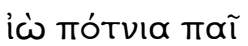

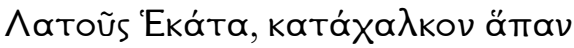

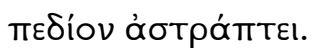

Ó senhora filha de Leto,

Hécate, repleta de bronze

a planície reluz. 
Neste caso, embora não haja um pedido expresso de se anular algum malefício, há um enunciado verbal que caracterize o apotropeu: a interjeição i⿳亠 que é, segundo Amiech (2004, p.282), "um grito apotropaico utilizado para conjurar um perigo" De fato, a tensão da iminente guerra fratricida vivenciada naquele momento exige alguma forma de defesa. No caso de Antígone, por se tratar de uma mulher não emancipada, resta apelar para o plano divino. Hécate, uma deusa virgem (assim como Antígone), então, surge como uma via de escape, embora caracterizada (assim como Selene acima) de maneira particular.

Tendo-se em mente a Teogonia de Hesíodo, é natural que Antígone se dirija a Hécate pois essa deusa é descrita como "nutriz de jovens" (koupotpóqos, 450). Entretanto, há um dado na invocação em questão que não se harmoniza com a poesia hesiódica: Hécate aí não é filha de Leto, mas de Astéria (409-411). A relação de Hécate com Leto seria, segundo este poeta, de neta e avó. Essa alteração dos dados da tradição que Eurípides propõe contribui para mostar uma determinada faceta de Antígone, que vinha sendo explorada desde a sua primeira intervenção religiosa na peça.

De fato, os atos religiosos dessa personagem sempre privilegiam a figuração filial da divindade invocada. Tal foi o caso visto na oração à Ártemis (151), à Selene (175) e agora à Hécate. Assim, a piedade de Antígone evoca sempre a relação familiar (entre os deuses) e prefigura, de certa forma, a ação de mãe e filha no quarto episódio, quando ela e Jocasta protagonizarão uma tentativa de cessar a guerra.

As outras duas orações de Antígone aparecem justapostas. Ambas as orações à Nêmesis (e aos "trovões de Zeus") e à Ártemis fecham a primeira parte da participação da filha de Édipo na peça. O contexto ainda é o da teichoskopia, mas agora a apresentação dos sete invasores de Tebas já foi concluída. A tensão pré-guerra, portanto, torna-se mais intensa. Os versos da primeira oração são (182-9):

$i \omega ́$

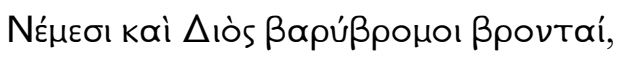




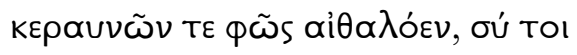

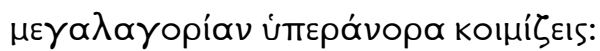

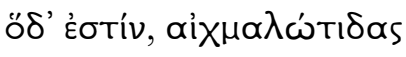

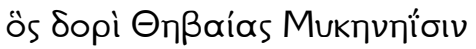

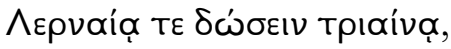

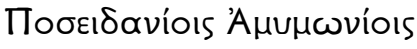

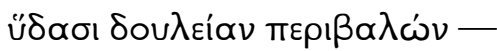

Ó Nêmesis, barítonos trovões de Zeus

e refulgente brilhar do relâmpago, és tu

quem extirpas o excessivo orgulho.

É este quem diz

que, cativas, dará as tebanas

às micênicas damas e ao tridente de Lerna,

lançando sobre elas servidão

às águas de Posídon e Amimone.

Nêmesis figura, segundo Hesíodo, entre as descendentes da Noite, e é por esse

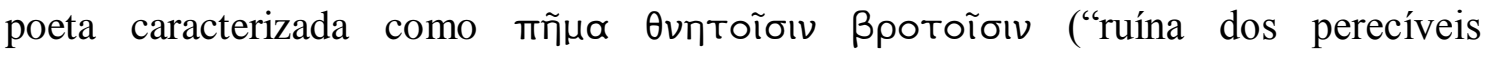
mortais ${ }^{98}$ "). A invocação a essa deusa neste momento se ajusta bem à situação por que passa Antígone: seu preceptor acaba de lhe mostrar o último guerreiro argivo, Capaneu,

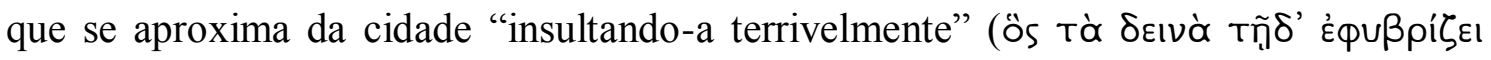
Tó $\lambda \varepsilon$ l, 179). Medda (2002, p.231), a propósito, relaciona-a com a punição de jactâncias superconfiantes. Ademais, tal como ocorre na primeira invocação de Antígone à Hécate (109), a interjeição apotropaica íம se repete aqui (183) .

A segunda oração a Ártemis representa as últimas palavras de Antígone no prólogo. Com uma linguagem marcadamente iterativa (repetem-se aí dois vocábulos: a

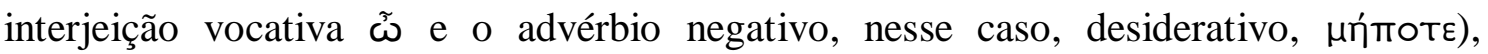
Antígone recorre novamente à deusa virgem. Craik (1988, p.181) assinala que essa oração final indica a estreita união entre o destino da cidade e aquele da suplicante.

\footnotetext{
${ }^{98}$ Teogonia, 223-4, tradução de Torrano (2009).
} 
Aqui, de novo, a filiação da deusa invocada está bem marcada: “Ártemis, fillha de Zeus” (190-2):

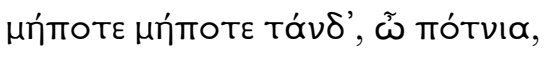

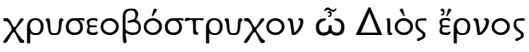

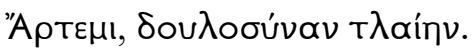 \\ Jamais, jamais, senhora Ártemis, \\ filha de Zeus dos louros cabelos, \\ padeça eu dessa escravidão.
}

190

Com o fim do prólogo, conclui-se também a participação religiosa de Antígone e Jocasta no drama. Elas ainda exercerão papeis fundamentais no desenrolar da trama trágica, mas nenhum relevo será mais dado ao plano divino. Por meio de atos religiosos de duas personagens femininas, no caso, mãe e filha, ao prólogo cumpriu delinear a tonalidade geral da peça. Jocasta traçou os contornos do movimento pendular entre a esperança e a desgraça dento da ação dramática, e Antígone prenunciou a centralidade do procedimento maternal no contexto da guerra tebana.

\title{
2.3 Problematik, Metodologia
}

A relação entre religião grega e a tragédia As Fenícias é o eixo central de todo este capítulo. Os atos religiosos visto acima, porém, ainda não entram na categoria da chamada "análise transcendente". Eles evidenciam como o tragediógrafo se vale de elementos religiosos para a construção de um universo metafórico que estabelece a ligação entre os personagens dramáticos e o enredo em que eles estão inseridos. Até aqui, portanto, a análise se ateve ao âmbito intradramático. Agora, o intuito desta seção 
é fornecer os instrumentos necessárias para se pensar adiante em um interpretação que aborde aspectos extradramáticos, ou performáticos, da peça.

Como ponto de partida, é preciso retomar um dado básico a respeito do contexto de encenação da tragédia grega: o gênero trágico é insperável de sua ocasião de performance, ou seja, do festival As Dionísias. Como premissa teórica, portanto, deve ser estabelecida a vinculação conceitual drama-festival, que, ulteriormente trará o questionamento acerca da vinculação cultual deste par: a tragédia tem participação cultual nas Dionísias? Estudos contemporâneos estão longe de atingir um consenso. Segundo Seaford (2006, p.94), por exemplo, “o drama ateniense do período clássico derivou-se em parte do ritual dionisíaco e era dionisíaco em seu contexto espacial e temporal". Por outro lado, para Taplin (1978, p.162), Winkler (1985, pp. 26-62) e Scullion (2002), a tragédia "nada tem a ver com Dioniso".

Inserindo-se nesse debate, indagar-se-á aqui se é possível visualizar em $A s$ Fenícias algum indício ritualístico ou cultual. Se a resposta for positiva, então restará interpretar qual a relação dessa peça com o universo cultual dionisíaco de festival. Para isso, o objetivo desta seção será expor a metodologia concercente à identificação de traços rituais a partir unicamente do âmbito textual. Desse modo, essa metodologia formará a base para uma posterior análise extradramática do texto a fim de averiguar se a chamada "ritualização do teatro ${ }^{99 "}$ se aplica à peça em questão.

Para o conceito de ritual, sejam consideradas as palavras de Bierl (2009, p.13)(negrito nosso):

Minha tese de que a dança-canção (“dance-song) do coro é também ritual não irá advir meramente como um argumento circular baseado em conexões superficiais e dependentes de conexões de tópicos, mesmo que os conceitos performance e ritual sejam admitidamente bastante difíceis de serem definidos. A extensão dos conceito de ritual para aquela da dimensão da performance é de importância central nessa conexão. No que se seguirá, portanto, ritual será entendido não simplesmente como uma série particular de eventos que ocorrem em um

\footnotetext{
99 Bierl (2009, p.3) nota que estudos que abordem o caráter performativo e ritual do coro vêm sendo negligenciados pelos estudos contemporâneos. Para estudos contrários a essa abordagem teórica, ver Lonsdale (2000) e Scullion (2002). Kowalzig (2007), porém, além de apresentar metodologia semelhante a desta dissertação, entende que os coros trágicos funcionavam como ritual na, e para, a sociedade ateniense que os produziu.
} 
festival, uma cerimônia dentro dos limites do culto que a pólis oferece a Dioniso, mas será também refletido na microestrutura do texto.

Segundo Bierl (2009, p.14), as características básicas do ritual são: 1)formalidade (convencionalidade), 2)estereotipia (rigidez), 3)condensação (fusão) e 4)redundância (repetição). É fácil observar que o gênero trágico obecede aos dois primeiros quesitos. "Convencionalidade" e "rigidez" são vistas na estrutura prédeterminada (metro particular, divisão em episódios e cantos corais, número de atores pré-estabelecido) que todas as tragédias apresentavam. Ademais, o mito, matéria-prima de quase todas as tragédias, padrão de "formalidade" e "estereotipia", também pode conferir ritualidade. Relacionando o ritual à performance dramática, "a narração mítica pode ser acionada no ritual ${ }^{100}$,, sucedendo-se daí que, pelo rito, o mito se transforma em ação ("enactment"). A relação do mito com o ritual, portanto, se dá no fato de que o coro ritualmente reconfirmará os valores e as normas apregoadas por aquele mito que, por tratar de narrativas tradicionais, são relevantes para a unidade da comunidade ${ }^{101}$.

Por outro lado, "condensação" e "rigidez" demarcam aspectos pontuais do ritual que devem ser analisados em trechos delimitados da tragédia, principalmente entre as intervenções do coro. Para Bierl (2009, p.20), "os coros dramáticos, embora fixados dentro de um enredo, representam em grande medida coros rituais" e, quando o coro se pronuncia com os pronomes "Eu/Nós", ele se identifica com a audiência reunida do teatro de Dionísio para adorar o deus da tragédia. Assim, os conceitos de "autoreferencialidade" ("self-referentiality") e "projeção coral" ("choral projection") aplicados ao texto ajudarão a entender se, de fato, "o coro e audiência, assim como nos cantos corais líricos, se juntam num ato ritualístico".

Segundo Bierl (2009, p.30), auto-referencialidade ${ }^{102}$ não deve ser confundido com "meteteatralidade" ("metatheater"): “enquanto nós entendemos a autoreferencialidade dramática como uma expressão em que alguém se refere à própria atividade durante a performance que ocorre no aqui e agora, ou seja, à própria ação

\footnotetext{
${ }^{100} \operatorname{Bierl}(2009$, p.7).

${ }^{101}$ Ver Bierl (2009, pp.16-7).

${ }^{102}$ Ver também Sourvinou-Inwood (2005, p.297).
} 
ritual, a metateatralidade tem a ver com a problematização e o discurso reflexivo sobre o fenômeno estético do teatro". "Projeção coral", por sua vez, tem a ver com o caráter extradramático da encenação, pois ela denota a capacidade que o coro tem de se desvencilhar do aqui e do agora da trama da peça em que ele está submerso e, assim, poder emergir para o nível espacial e temporal da audiência do teatro ${ }^{103}$.

Bierl (2009, pp.58-61) obtém, por exemplo, a partir do drama satírico O Ciclope de Eurípides, um quadro funcional que liga aspectos da análise ritualística a trechos do referido drama. Especificamente, ele se detém à fala do personagem Sileno, que comenta a atividade dos sátiros no fim do prólogo (37-72). A título de ilustração, reproduz-se aqui, resumidamente, os resultados desse autor:

Movimento dramático do coro - imitação da dança dos sátiros (ó́kKıvıs - nome da dança dos sátiros utilizada nos dramas satíricos): "os coros satíricos em particular, (...) são frequentemente apresentados em ação ou imitam ações pantomimicamente com movimentos de dança ${ }^{104}$ ";

Auto-referencialidade - referência verbal à dança dos sátiros por meio da partícula $\nu \tilde{U} \nu$ ("agora") que enuncia a dança como ocorrendo no hic et nunc da performance: "o ritual da presente performance cita e, fazendo isso, presentifica o evento mítico do passado ${ }^{105,}$;

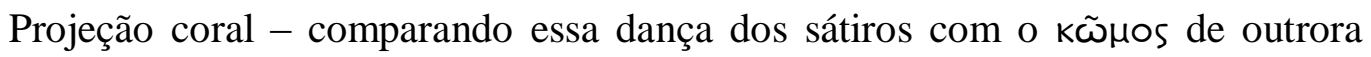
(que pertence ao plano mítico - a dança de Dioniso e dos sátiros quando eles marcharam contra Calidão), a dança dramática pode ser entendida também como uma dança ritual extradramática, ou seja, em louvor a Dioniso: “O deus central [Dioniso], em cuja honra a peça acontece, por meio de auto-referencialidade ritual, estabelece uma

\footnotetext{
${ }^{103}$ Há que se ressalvar que o estudo de Bierl trata especialmente da comédia. Contudo, uma de suas conclusões sobre a questão ritual se baseia no gênero dramático como um todo, não exclusivamente na comédia: "quando se analisa o coro [dramático] pelo ponto de vista da performance, torna-se claro que as duas funções, a dramática e a ritual, são analiticamente difíceis de se separarem, mas se fundem por um longo processo histórico em uma unidade ambivalente" (2009, p.47). É certo que, especificamente no que concerne à tragédia, sua análise tende a diminuir-lhe o expressão ritualística, e um de seus argumentos para isso é mostrar que, como a narrativa e o mito estão no primeiro plano ("foreground"), o aspecto ritual e performático recua para o segundo plano ("background").

${ }^{104} \operatorname{Bierl}(2009$, p.58).

${ }^{105} \operatorname{Bierl}(2009$, p.59).
} 
ponte entre o "aqui e agora" [momento da performance] e o "lá e o então" [momento mítico $\left.{ }^{106}\right]^{\prime \prime}$.

Finalmente, a conclusão geral de Bierl (2009, p.267-69) é:

Nós estamos comprometidos em deixar para trás o modo teleológico de pensar e enfatizaremos a conexão estrutural das formas teatrais e rituais. A gênese diacrônica de um "início ritual” para uma produção teatral desenvolvida é, então, substituída por uma relação de interdependência. Os dois fenômenos não devem ser entendidos como um "ainda não" nem um "não mais", mas podem estar presentes simultaneamente. O que é comum entre eles baseia-se na performatividade: ambos, teatro e ritual, são encenados em forma de espetáculo em frente de toda a cidade.

(...)As produções dramáticas ocorriam em um contexto cultual em honra do deus Dioniso. Outras celebrações ocorriam antes e depois, de modo que o complexo como um todo figurava como um continuum ritual. Por meio de típicas estratégias de imersão, a ritualística e a tradicional cultura coral são também integradas ao drama.

(...)A mimese da cultura coral que se estabelece pragmaticamente não é equivalente à imitação fundamentalmente literária, mas pode significar uma autêntica reativação, uma reexperimentação e revocação dos modelos corais, que, nas sociedades desta natureza, são onipresentes na imaginação mítica assim como nas práticas rituais.

Sourvinou-Inwood (2005) também apresenta uma estruturação texto-ritual trágica que pode trazer implicações religiosas para as peças tomadas individualmente. A fim de analisar a proximidade entre o universo encenado no palco e o universo real da audiência do teatro, a autora propõe dois conceitos concernentes à mecânica da interação encenação-audiência: "dispositivo de distanciamento" ("distancing device") e “dispositivo de aproximação" (“zooming device"). A definição de cada um deles é dada da seguinte maneira:

-Dispositivo de distanciamento: produz o efeito de distanciar a ação dramática do universo da pólis ateniense do quinto século;

${ }^{106} \operatorname{Bierl}(2009$, p.59). 
-Dispositivo de aproximação: produz o efeito de trazer o universo do drama mais perto, incitando o público a relacionar as experiências e pressupostos próprios diretamente com a peça.

Assim, a performance ritual exercida pela tragédia se daria sobretudo por meio do "dispositivo de aproximação", pois é por ele "que o universo da audiência é penetrado pelo universo da tragédia ${ }^{107}$,. De fato, Sourvinou-Inwood (2005, p.297) ainda destaca que essa "penetração" pode ocorrer de duas maneiras: a)o personagem do mundo da tragédia é ativado como parte de uma performance ritual acontecendo no mundo da audiência; e b)o superficial "outro" mundo heroico da tragédia é trazido muito perto, na verdade apresentado como idêntico ao mundo da audiência, especialmente no que diz respeito às realidades religiosas.

Somando a esses artifícios o conceito de auto-referencialidade coral, SourvinouInwood (2005, p.298) afirma ocorrer uma "ativação" dos personagens do coro: durante um canto coral hínico, por exemplo, a audiência perceberia esse canto não somente como cantado pelos atores representando a trama da tragédia, mas também exercendo um papel religioso para fora dos limites do drama. O espaço-tempo, portanto, do coro transcende para o espaço-tempo da audiência, e o ritual realizado dramaticamente passa a ser também um ritual de facto $^{108}$, ou seja, extradramático. A isso a autora chamou de "natureza dual do canto", e a isso acima se denominou "interpretação transcendente" da tragédia.

Dessa forma, o objetivo da próxima seção será interpretar como As Fenícias dialogavam com as diversas instâncias religiosas da pólis, principalmente com relação ao universo do culto e do ritual. Conforme assinala Calame (1995b, p.14), a poesia grega é essencialmente uma poesia de ocasião, logo é de se supor que a referida peça estivesse profundamente conectada ao contexto cívico-religioso (As Dionísias) em que se deu sua produção.

\footnotetext{
${ }^{107}$ Sourvinou-Inwood (2005, p.297).

${ }^{108}$ Ver aplicação desses conceitos feita para a peça Eumênides de Ésquilo em Sourvinou-Inwood (2005, p.298).
} 


\subsection{Mito e Ritual em As Fenícias}

Para investigar se há alguma evidência da chamada "ritualização do teatro" na peça As Fenícias, serão analisados a seguir dois cantos corais, a saber, o párodo e o primeiro estásimo. A escolha do párodo e do primeiro estásimo se deve sobretudo ao fato de que o coro aí exerce uma função momentaneamente afastada do desenvolvimento da ação dramática liderada pelos personagens: como visto no capítulo 1, nesses trechos o coro principalmente se ocupa em se autoapresentar e narrar o passado de Tebas.

Realmente, não é possível tratar a peça como um todo como ritual: são determinadas partes dela (se as houver) que podem conter traços de ritualidade. Segundo Bierl (2009), é essencialmente o coro que exerce função ritualística no drama. Ora, em As Fenícias, o primeiro traço marcante do coro diz respeito justamente ao seu

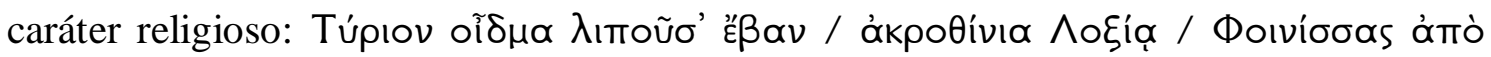

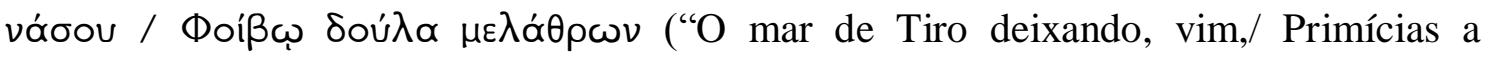
Lóxias,/ Da ilha Fenícia/ Criada do templo de Febo ${ }^{109}$, , 203-205). Assim, em um primeiro plano (i.e. o dramático), o coro manifesta sua natureza essencialmente cultual, apresentando-se como oferenda a Lóxias.

Na crítica de Bierl (2009, p.55) a respeito do caráter menos ritualístico do coro trágico (em comparação com o coro cômico), seu argumento considera sobretudo a sua constituição: "o coro da tragédia apresenta uma inclinação de ser formado por inconspícuos personagens da trama, tais como anciãos e mulheres curiosas ('female bystanders')". Em As Fenícias, todavia, não é possível qualificar o coro como "inconspícuo": sua representatividade dentro da história de Tebas é ressaltada constantemente pela sua consanguinidade com os fundadores dessa cidade ${ }^{110}$. Assim, resta observar, valendo-se da instrumentação teórica vista na "metodologia", se há nele também indícios de uma atuação em um outro plano, a saber, o extradramático, onde a "ritualidade teatral" aconteceria.

\footnotetext{
${ }^{109}$ Sobre o caráter político do coro, Kovacs (2002, p.233) explica que essas mulheres fenícias talvez fossem mulheres livres em serviço de Apolo em ação de graças por alguma benção concedida a Tiro pelo deus.

${ }^{110}$ Conforme mostrado na seção 1.2 desta dissertação.
} 
Em um primeiro nível ritualístico, é preciso analisar os dados que dizem respeito à auto-referencialidade coral. O párodo (202-260) contém uma quantidade significativa de verbos que se remetem ao próprio coro, ou seja, na primeira pessoa do singular (modo indicativo) e no feminino singular (modo particípio): $\lambda_{ı}$ по $\sigma^{\prime}$ (202),

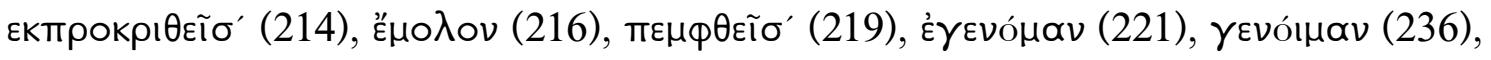

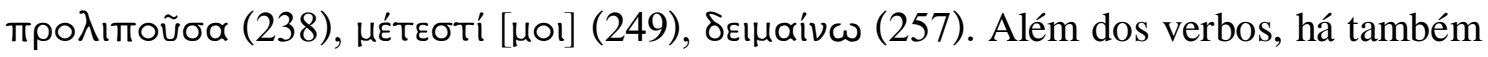

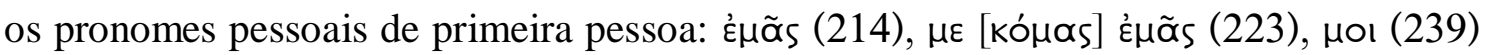
e $\mu$ ol (249).

À auto-referencialidade do coro deve-se acrescentar o fato de que o coro se apresenta utilizando máscara. Segundo Calame (1995b, p.98), “a máscara se torna a representação da realidade mitológica e sagrada na qual a ordem da comunidade se funda", donde se pode depreender o seguinte esquema em que se interagem máscara e ritual:

Máscara ("papel de atuação") - ator inserido numa sequência ritualística;

Cidadão que veste a máscara - enunciador do ritual (assim como da correspondente narrativa);

O “eu” narrador (vestido com a máscara) - o "ele”, sujeito do ritual.

Calame (1995b, p.99), em conclusão, ressalta que é então produzido o efeito de se igualar o "eu" de quem veste a máscara e o "ele" do que é representado pela máscara. Dessa forma, a máscara seria um intermediário entre a ação dramática e o ritual. Ora, como se sabe, o culto dionisíaco se expressava por meio do uso ritual de máscaras ${ }^{111}$. Na tragédia grega, ademais, a máscara teria um papel extradramático, conforme explica Calame (1995b, p.107): “[a máscara] confere a quem a usa a habilidade, não de ser, mas de se tornar outro. Assim, o 'eu' do enunciador (aquele que usa a máscara) continua a existir, enquanto o 'ele/ela' é criado passo a passo pela ação", ou seja, o "eu” do enunciador, portanto, seria o sujeito do ritual.

${ }^{111}$ Ver Seaford (2006). 
Para haver o ritual, porém, seria preciso supor uma certa identidade entre o coro e a audiência da tragédia. Nas palavras de Calame (1995b, p.142): “é este 'eu' a encarnação do grupo coral como ator e protagonista na ação ou a encarnação do enunciatário, ou seja, o público para quem a tragédia é direcionada?’.

Segundo Calame (1995b), é possível esboçar da seguinte maneira um quadro de relação entre as pessoas gramaticais e o seus respectivos referentes:

$1^{a}$ pessoa do singular: abrange todo o grupo do coro.

$2^{\mathrm{a}}$ pessoa do singular: refere-se a dois lugares específicos, Monte Parnaso (local onde as coreutas devem cumprir rituais a serviço de Apolo, 226, 232), e Argos (local de origem do exército de Polinices, 256).

$3^{\text {a }}$ pessoa do singular: deuses (Apolo e Ares).

O uso da primeira pessoa do singular, segundo Calame (1995, p.148), exerce uma função ritualística por meio da transposição de pessoas, isto é, ele iguala a pessoa do coro à pessoa do espectador: "o 'eu' generalizante e indeterminado do coro 'fala' pelos espectadores que estão honrando Dioniso". Um indício, então, da ativação da função ritualística do coro pode ser visualizado quando este se expressa em primeira pessoa. Nesse caso, por conseguinte, o coro e os espectadores seriam interligados num ato cultual.

No párodo da peça As Fenícias, como visto acima, o coro manifesta-se se dirigindo a dois pontos geográficos. Com relação à invocação ao monte Parnaso, situada no epodo, é possível observar um conteúdo dionisíaco patente. O monte em si é um renomado local de atividade cultual dionisíaca ${ }^{112}$ e o vinho está indissociavelmente relacionado a Dioniso:

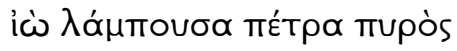

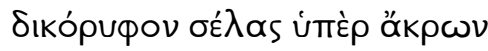

${ }^{112}$ Ver Mastronarde (1994, p.220). 


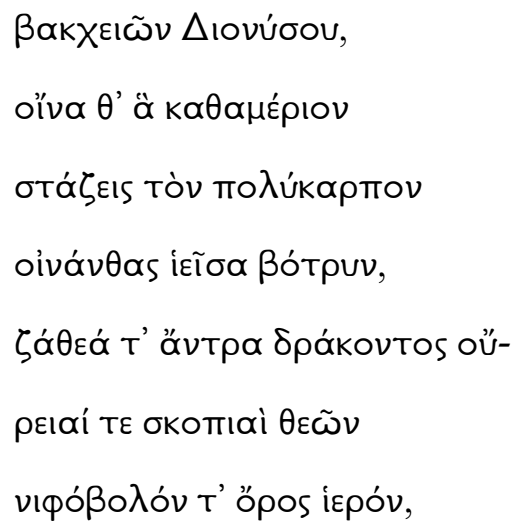

Ó rocha que acende com o fogo

Uma chama dúplice sobre os cimos

Báquicos de Dioniso,

E a vinha que dia-a-dia

Goteja, o frutuoso cacho

Produzindo de sua flor

E a sacra gruta da serpente,

As alturas vigilantes dos deuses

E ó sagrado monte nevado ${ }^{113}$,

Os versos que se seguem a essas invocações corresponderão a uma súplica que, conforme se propõe aqui, constituirá a chamada "projeção coral". Determinar, porém, a divindade a quem essa súplica se destina é problemático, e, ao mesmo tempo, essencial para se entender a referida "projeção coral". A hipótese desta dissertação é que o coro aqui esteja se referindo a Dioniso, conferindo ao epodo como um todo uma unidade temática centrada nesse deus.

As edições de Mastronarde (1994) e Kovacs (2002) divergem com relação ao

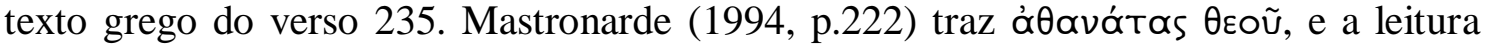
desse verso fica restrita às divindades femininas - no caso, o autor elenca três possíveis, Ártemis, Atena e Gaia. Kovacs (2002, p.234), porém, e com ele, Medda (2006, p.144),

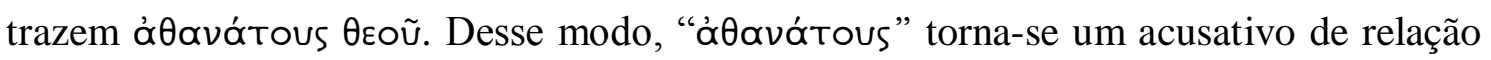

\footnotetext{
${ }^{113}$ Os versos 232-34 se referem à caverna Corícia habitada anteriormente pela serpente Píton e à Colina do Arqueiro, de onde Apolo atirou sua flecha para matar aquela serpente, cf. Medda (2006, p.144).
} 
e " $\theta \varepsilon \circ$ ơ" necessariamente sugere uma divindade masculina - de fato, Medda (2006, p.318) a identifica como Apolo. Adotando, porém, essa última edição, interpretamos o $\theta \varepsilon \circ$ ũ como referente a Dioniso: embora o monte Parnaso seja tipicamente relacionado a Apolo, aqui o universo de referências circunscreve-se ao âmbito dionisíaco dos "cimos báquicos" (227-8) e da “vinha” (229).

Nesse caso, portanto, a projeção coral se resolve em torno de Dioniso. Os versos são (234-6):

$$
\varepsilon \mathbf{l}^{-}
$$

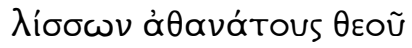

Xopòs yevoínav äpoßos

quisera eu ser, sem medo, o coro

dançante do deus para os imortais

Por meio da auto-referencialidade dramática, ou seja, por meio da menção de sua própria atividade ( $\chi \circ \rho o ̀ s ~ \gamma \varepsilon v o i ́ \mu \alpha v$ ), pode-se estabelecer uma comparação entre (i) o coro e a dança das mulheres fenícias (enquanto personagens) e (ii) o coro e a dança dos cidadãos atenienses (enquanto atores). Eis, portanto, a realização da "projeção coral", que é, na verdade, resultado (e clímax) da sucessão dos diversos elementos autoreferenciais enumerados acima. Assim, somando-se todos esses fatores, é possível identificar um movimento progressivo entre as partes que produz o efeito de ritual em que o coro transcenderia os eventos da ação dramática e provocaria a interrupção da ilusão teatral, transformando-se, finalmente, num coro cultual do aqui e agora da plateia. O quadro a seguir esboça o desenho desse movimento:

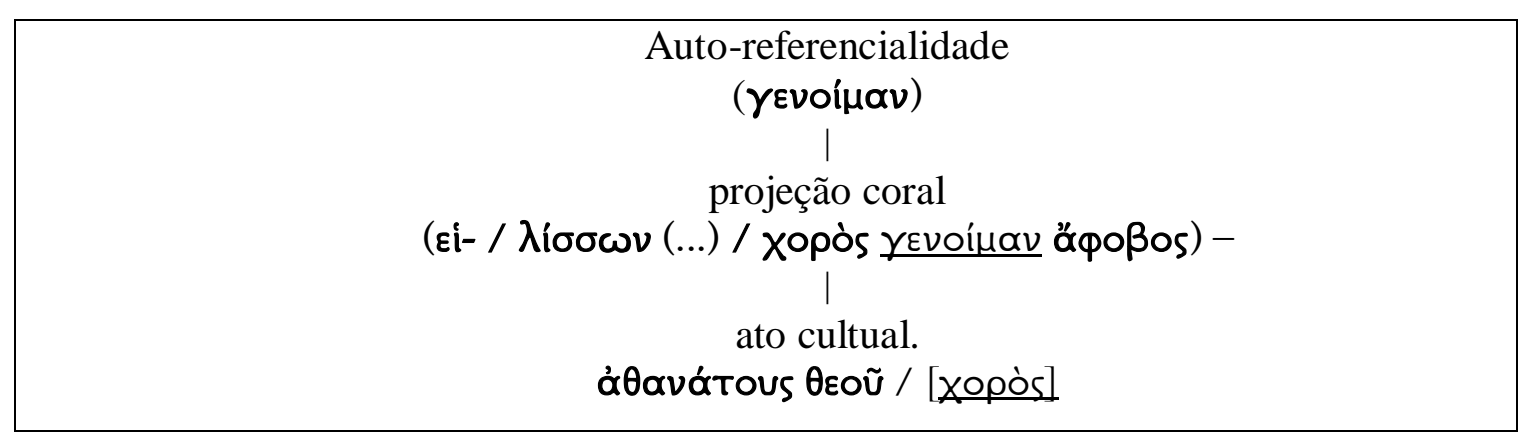


O epodo do párodo, portanto, representa a culminação de toda atividade cultual delineada pelo coro desde a estrofe alfa. Embora as mulheres fenícias se definam como "servas de Febo" (205), o epodo permite visualizar também o sentimento religioso voltado a Dioniso, o deus que, afinal, antes de todos os outros, era o responsável pela própria representação teatral.

$\mathrm{Na}$ segunda parte do párodo (estrofe e antístrofe beta), o coro altera completamente o teor de seu discurso. Se antes ele se ocupara apenas em apresentar sua terra de origem e o motivo de sua vinda a Tebas, agora o assunto são os acontecimentos presentes da cidade. As evidências de uma atividade cultual extra-dramática, então, serão analisadas por meio de outro recurso, a saber, o efeito "aproximativo" - ativado pelo advérbio temporal $\nu \tilde{\nu} \nu$ e por duas partículas dêiticas $\delta \varepsilon$. Os versos são (239-249, negrito nosso):

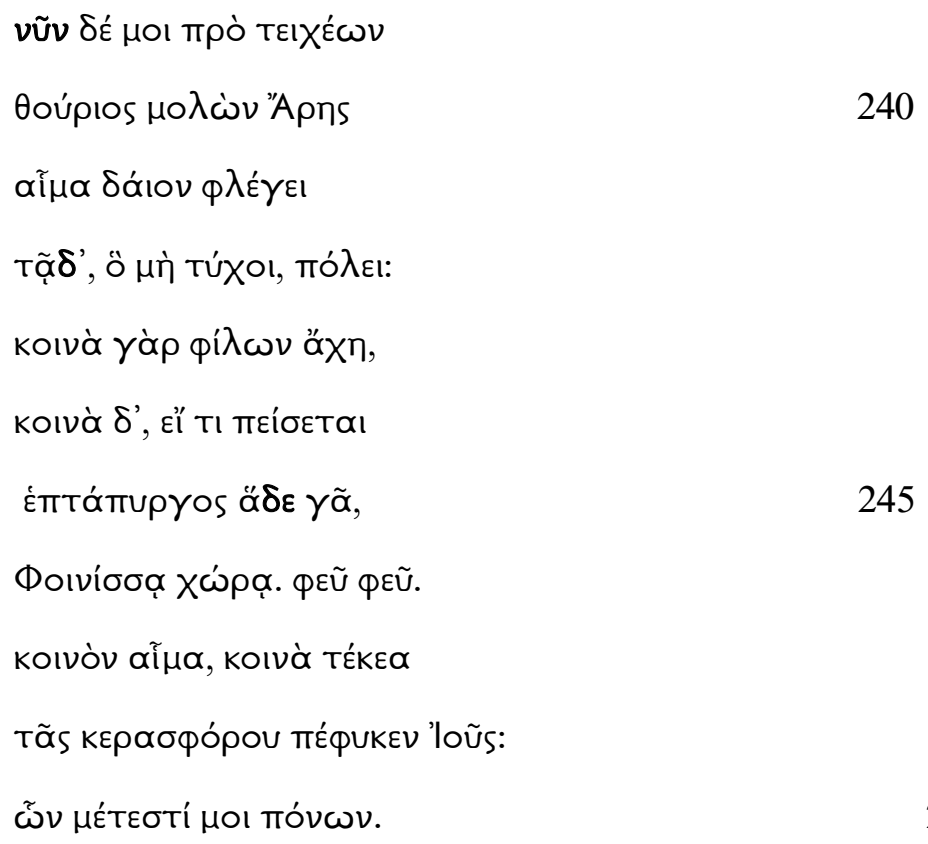

Eis diante das muralhas

Vindo impetuoso Ares

Que inflama banho de sangue adverso

Contra a cidade - tal não ocorra! 
Comum é a dor entre amigos,

Comum será a dor, se algo sofre

Esta terra de sete torres,

à terra fenícia. Ai, ai!

Comum é o sangue, comum

A cria gerada da cornífera Io,

Cujas dores me são presentes.

249

Nesse caso, de acordo com a teorização de Sourvinou-Inwood (2005) vista na seção "metodologia", as partículas assinaladas igualariam o espaço-tempo do coro dramático (Tebas, guerra entre Polinices e Etéocles) ao espaço-tempo da plateia (Atenas, ano da representação de As Fenícias). O vũv aproxima o coro ao tempo da

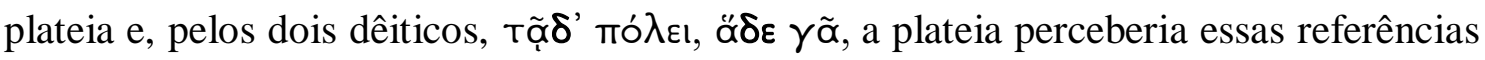
à "cidade" e à "terra" como referências às próprias cidade e terra, isto é, ao espaço de Atenas. O "dispositivo de aproximação" ainda seria amplificado pela identificação coro-

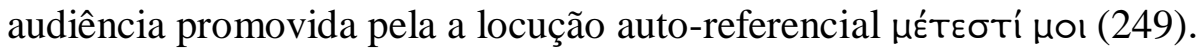

Desse modo, considerando-se todo o acervo teórico auferido acima, é possível

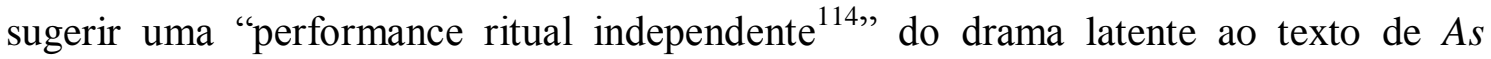
Fenícias. Neste sentido, ocorreria, então, uma "penetração" do universo da plateia no universo dramático, ou seja, segundo Sourvinou-Inwood (2005, p.297), em casos assim, a audiência é incitada a relacionar suas experiências com os acontecimentos do coro. Ora, sabe-se que Atenas nesse momento se encontrava em plena guerra contra Esparta (“guerra do Peloponeso"). É possível presumir então, especificamente para a estrofe beta do párodo, que a peça promovesse a lembrança dessa guerra e, por que não, exercesse assim a função de catarse apregoada por Aristóteles.

O $1^{\circ}$ estásimo (638-689) mostra uma situação dramática diversa: o coro a essa altura já presenciou a disputa verbal entre Etéocles e Polinices cujo efeito reconciliatório foi nulo. Prestes a vivenciar uma guerra entre os exércitos tebano e argivo, o coro se manifesta recordando o passado (mítico) de Tebas na estrofe (638-657) e na antístrofe (658-675), e, por fim, invocando Épafo, ancestral em comum entre as

\footnotetext{
${ }^{114} \operatorname{Bierl}(2009$, p.85).
} 
fenícias e os tebanos, e Perséfone e Deméter, no epodo (676-689). Como visto no capítulo 1, a narrativa mítica presentifica o passado (mítico) no presente da ação dramática, e aqui essa presentificação adquire nuances especiais, pois se trata da história de Dioniso.

A "ritualização do teatro" da estrofe do $1^{\circ}$ estásimo, então, pode ser vista como essencialmente dionisíaca, tal como o contexto do festival em que a peça foi encenada. O fenômeno da "projeção coral" pode ser visualizado aí por meio de um conteúdo e de uma sonoridade propriamente cultuais. Dentro da narrativa mítica do nascimento de Dioniso, o coro faz alusão aos coros rituais dançantes das bacantes. Não há em todo esse trecho qualquer indício de "auto-referencialidade", mas é possível vislumbrar o “dispositivo de distanciamento" sendo ativado. Os versos são (649-657, negrito nosso):

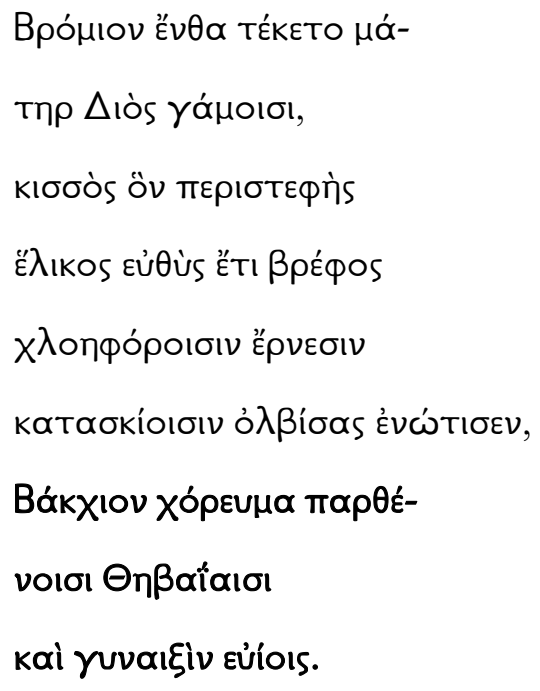

A Brômio aí gerou sua

Mãe, esposada de Zeus, 650

A quem a hera, rodeando-o

Ainda criança em coroa,

Com verdejantes brotos

Envolve-o em sombras e o abençoa:

Ele é honrado em báquica dança pelas 655

Moças tebanas e pelas

655bis

Mulheres de evoés. 
Sugerem a "projeção coral" aqui os versos em negrito, principalmente o

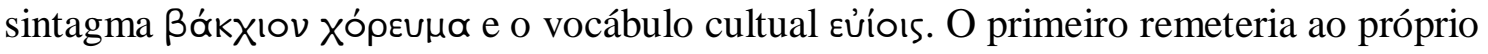
evento em que se dava a encenação da tragédia, as Dionísias, ou seja, suscitaria a projeção espaço-temporal do coro dramático para um coro cultual pertencente ao festival. Por outro lado, eviíoıs, por si só, designa, segundo Mastronarde (1994, p.339), um epíteto cultual de êxtase báquico. Assim, a sonoridade dessa palavra, que é também um grito ritual báquico, intensifica a projeção. Amiech (2004, p.388) nota que eưiors

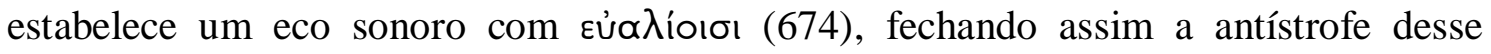
estásimo de maneira circular. De fato, como visto na seção "metodologia”, a redundância, ou repetição, é uma característica fundamental do ritual.

É preciso reconhecer, porém, que a ativação do "dispositivo de distanciamento" afasta o coro da audiência ateniense, principalmente porque o coro é determinado como

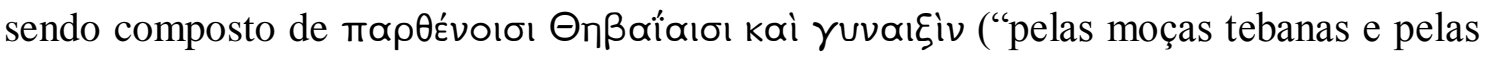
mulheres", 655-7), ou seja, o universo evocado é aquele das mulheres tebanas. Não decorre daí, entretanto, que o caráter ritual desse trecho seja esvaziado, pois apenas a identidade coro-audiência foi afetada. Ora, embora aqui a audiência não se iguale ao coro como no exemplo do párodo, a projeção espaço-temporal se mantém, que é o fator principal para a ativação do ritual.

Quanto ao epodo, no caso da oração a Épafo, à Perséfone e à Deméter, vê-se a "ritualização do teatro" em sua plenitude. Serão encontrados aí a auto-referencialidade, a projeção coral, o "dispositivo de aproximação", além de outros elementos de apoio a esses mecanismos. Os versos são (676-689):

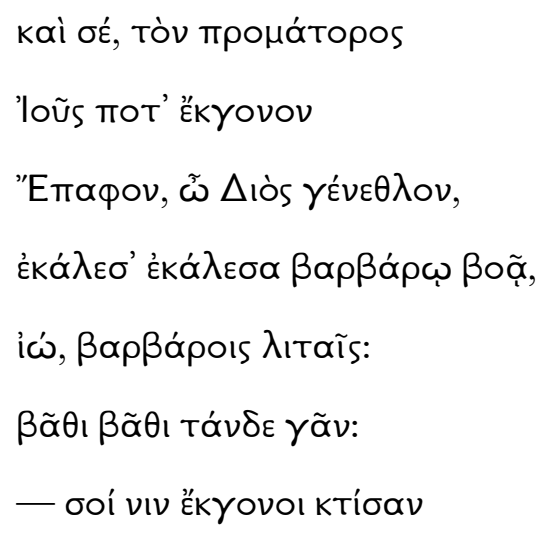




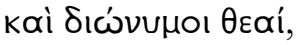

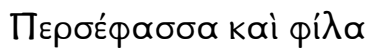

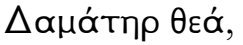

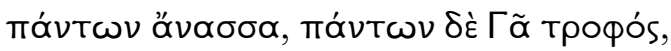

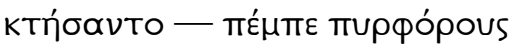

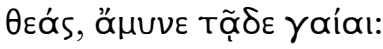

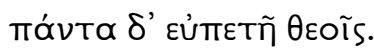

E a ti, da primeva mãe

Io descendente,

Épafo, prole de Zeus, clamei, clamei

A gritos bárbaros,

679bis

Ai!

680

Com preces bárbaras:

680bis

Vem, vem a esta terra:

Tua descendência a fundou,

E as deusas nomeadas em par,

Perséfone e a cara

Deusa Demeter,

Senhora de tudo,

686

Terra nutriz de tudo,

686bis

Tomaram posse. Acompanha as deusas

porta-fogo, protege esta terra.

Tudo é favorável aos deuses.

689

Em primeiro lugar, a respeito da oração em si, segundo Pulleyn (1997) as orações gregas eram compostas de três partes: (i) invocação, (ii) pars epica, ou argumentum, e (iii) pedido. A invocação se caracterizaria pelo uso do vocativo, ou seja, o chamamento pelo nome ou por algum atributo da divindade para quem se faz a 
oração. A chamada pars epica seria a parte em que aquele que faz a oração explica por que deve ter seu pedido (a terceira parte) atendido.

As referidas orações do epodo de As Fenícias têm a mesma divisão identificada por Pulleyn (1997). O coro inicia a oração com um vocativo. Caracterizado inicialmente pela presença do pronome pessoal de segunda pessoa do singular, kaì oé (676), esse vocativo, depois de um aposto que define a ascendência da divindade chamada (Tòv

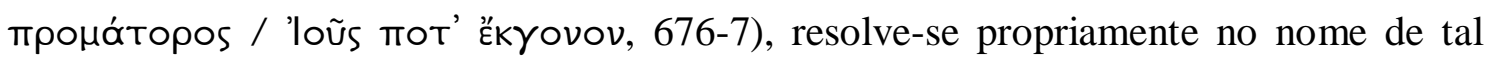
divindade, Épafo ('Етафоv, 678).

Tal invocação, note-se, pode-se dizer que se estrutura em um arranjo chamado "tricólon". Nesse caso, têm-se, respectivamente, dois vocativos e um aposto: (1)бé,

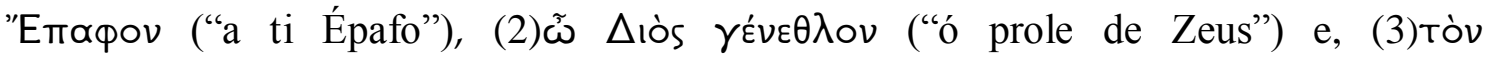

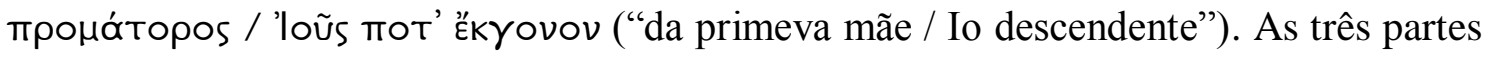
de um tricólon, segundo sua função gramatical, podem variar ${ }^{115}$, como ocorre aqui. Mais importante, porém, é constatar-se que o "tricólon" é especificamente próprio de um registro de linguagem pertencente ao âmbito religioso. A oração em questão, portanto, pelo menos teoricamente, seria adequada para uma atividade cultual, qualquer que fosse ela. De fato, Pulleyn (1997, p.146) chega a especular que "as tricola eram originalmente uma característica da linguagem religiosa que mais tarde se difundiu para a poesia retórica e secular".

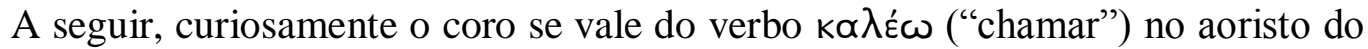
indicativo, Ėká $\lambda \varepsilon \sigma$ ' દ̇kó $\lambda \varepsilon \sigma \alpha$ (literalmente “chamei, chamei”, 678-9), que, segundo Amiech (2004, p.391) é denominado de "aoristo de instantaneidade". A utilização desse tempo verbal, então, poderia sugerir uma ruptura, ou uma superação, da "ilusão teatral": a instantaneidade do aoristo aí refletiria o tempo presente da encenação, e não somente o da ação dramática. A própria repetição dos verbos Éká $\lambda \varepsilon \sigma$ '́ká $\lambda \varepsilon \sigma \alpha$ (678-9) é chamada por Mastronarde (1994, p.331) de "anadiplose ritual", reforçando o caráter cultual - e não apenas dramático - da oração.

Além disso, a chamada "anadiplose ritual" não se resume apenas a esse verso. Ela, na verdade, aparecerá mais três vezes, realçando a formulação ritualística do epodo. Pode-se enumerar a sua recorrência da seguinte maneira:

\footnotetext{
${ }^{115}$ Cf. Pulleyn (1997, p.145), que dá exemplos de tricola formadas por orações subordinadas adjetivas, imperativos, etc.
} 


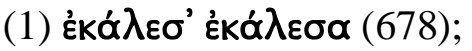

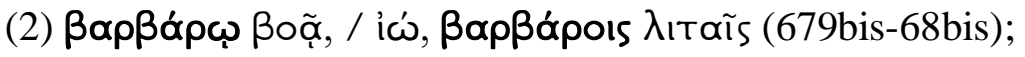

(3) $\beta \tilde{\alpha} \theta \imath \beta \tilde{\alpha} \theta \imath$ Tó $v \delta \varepsilon \gamma \tilde{\alpha} v(681)$;

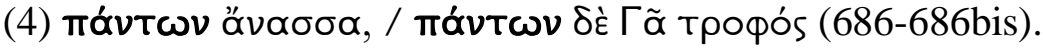

Se se trata de uma ação ritual per se, ainda não é possível afirmá-lo, mas, pelo menos quanto à adequação religiosa, esses verbos assim dispostos são convenientes. De novo segundo Pulleyn (1997, p.134), depois do vocativo, geralmente utiliza-se nas orações gregas um imperativo (sobretudo aoristo) para chamar a atenção do deus ( $\mathrm{k} \lambda \tilde{\mathrm{u}} \theta \mathrm{l}$,

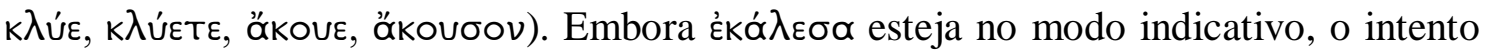
permanece o mesmo, ou seja, chamar a atenção.

A etapa posterior da oração grega, segundo Pulleyn (1997, p.136), seria o proferimento de outro imperativo, nesse caso expressando o desejo de que a divindade venha até aquele que por ela roga: $\dot{\varepsilon} \lambda \theta \varepsilon ́$ seria a palavra mais comum para se atingir tal esse objetivo, mas o autor também nota o raro uso do verbo $\mu \circ \lambda \varepsilon \tilde{\imath} v$. A oração do epodo do $1^{\circ}$ estásimo de As Fenícias, contudo, traz o verbo ßáivw no imperativo aoristo (dórico): $\beta \tilde{\alpha} \theta ı$ $\beta \tilde{\alpha} \theta ı$ тóv $\delta \varepsilon ~ \gamma \tilde{\alpha} v$ ("Vem, vem a esta terra", 681). Apesar da variação da escolha verbal (note-se que o registro de fala é diferente, pois o enunciador é de origem estrangeira), a finalidade deste verbo permanece a mesma de $\dot{\varepsilon} \lambda \theta \varepsilon ́$ ou $\mu \circ \lambda \varepsilon \tilde{\nu} \nu$.

Antes de se fazer propriamente o pedido, Pulleyn (1997, p.144) observa que muitas orações gregas trazem o particípio $\theta \varepsilon ́ \lambda \omega \nu$, isto é, quem faz a oração deixa claro para a divindade (ou herói) que ela só deve fazer algo de acordo com sua vontade. Evidentemente, o uso específico de $\theta \varepsilon ́ \lambda \omega \nu$, até onde se sabe, não constituía uma regra geral a ser seguida em todas as orações. A oração de As Fenícias em questão, por exemplo, não faz uso desse verbo, mas é possível encontrar um artifício petitório equivalente: encerrando sua fala, o coro ressalta que aos deuses nada é de difícil alcance

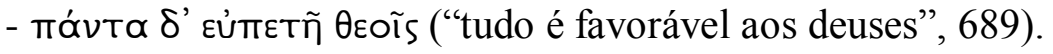


Todo o exposto acima mostra que essa oração dramática se encaixa com naturalidade no padrão religioso de oração grega. Resta analisar se há indícios de um possível caráter extra-dramático, e, para isso, é preciso abordar questões além das estruturais. Com efeito, é possível constatar uma espécie de sincretismo religioso entre a deusa Demeter e a deusa Terra que parece indicar que esta oração seria mais apropriada ao tempo de Eurípides do que ao tempo mítico da história de Édipo. Nesse caso, "o efeito aproximativo" seria verificável a partir de um dado histórico pertencente ao tempo da encenação da tragédia.

Quando o coro invoca Deméter e Terra, a variante grega para "Deméter" sugere

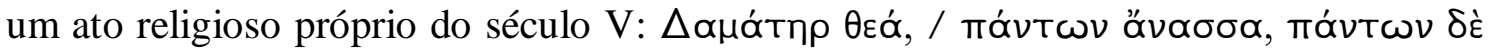
Га̃ трофós (“Deusa Deméter,/ senhora de tudo,/ Terra nutriz de tudo”, 685-686bis). No

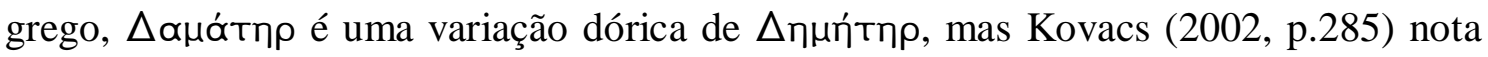
que "Demeter é aqui identificada com Ge (Terra), como se seu nome fosse Gemeter (Mãe-Terra)". De fato, segundo Mastronarde (1994, p. 344), é provável que o $\Delta \eta$ - de Demeter fosse uma variante de Ge do tempo de Eurípides. Em As Bacantes (274-6), peça que foi encenada poucos anos depois de As Fenícias, a mesma variante é encontrada.

É significativo ainda notar a caracterização feita pelo coro dessas figuras religiosas. Segundo Arthur (1977, p.175), Io, Épafo, Deméter e Perséfone, nesta oração, são apresentados em seus aspectos mais jubilosos: "A Io de As Fenícias não é a torturada donzela com chifres, selvagemente impelida pela a vagar pela terra, nem Deméter procura, desolada, sua filha perdida". Para a estudiosa, portanto, o canto é um pedido "e as invocações funcionam como mágica homeopática, clamando pelas divindades em seus aspectos beneficentes para que possam agir dessa maneira por Tebas ${ }^{116,}$.

Somando-se a tudo isso, ainda é possível observar o "dispositivo de aproximação" em operação nesse trecho, que é um dos principais mecanismos de aproximação do universo do drama ao universo da audiência. De novo, ele se manifesta pela presença do dêitico $\delta \varepsilon$. Significativamente, ele ocorre em dois pedidos: $\beta \tilde{\alpha} \theta_{\imath} \beta \tilde{\alpha} \theta_{\iota}$

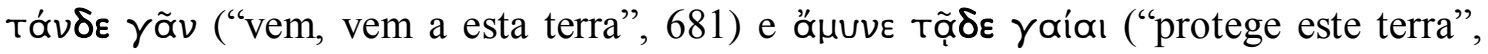
688). A utilização do verbo no modo imperativo direcionado a um deus mostra que o

\footnotetext{
${ }^{116}$ Arthur (1977, p.176).
} 
epodo é, independentemente dos mecanismos identificados aqui, um ato religioso. Assim, porque ele apresenta traços de auto-referencialidade, de projeção coral e do "dispositivo de aproximação", é possível perceber que, muito mais que o párodo, o epodo constitui um ato religioso sua forma plena. Não somente ele o é extradramaticamente, mas também dramaticamente.

De certa forma, pode-se vislumbrar uma comprovação dessa hipótese a partir da estrofe do $2^{\circ}$ estásimo. Findo o $1^{\circ}$ estásimo, o $2^{\circ}$ episódio centra-se nas deliberações de Etéocles e Creonte acerca das questões da iminente guerra. Etéocles sai de cena ordenando que seus servos o vistam com os trajes de guerra (779-780). Nesse momento o coro entra e, os primeiros versos de seu canto estabelecem uma contraposição entre a natureza de Ares e Dioniso:

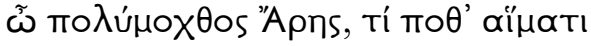

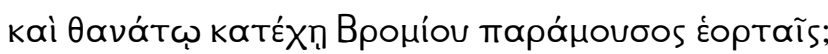

Ó Ares pungente, por que te arrebatas

com morte e sangue, destoando-te das festas de Brômio?

Como é possível entender essa referência a Brômio se, no plano da ação dramática, nenhum traço dionisíaco tenha sido posto em relevo? Em outras palavras, como entender esse aspecto "destoante" evocado pelo coro, se em nenhum momento da peça as personagens estiveram em situação de "festa de Brômio"?

Kovacs (2002, p.297) afirma que Dioniso é aí mencionado como "patrono da música e da dança, seu papel nas Dionísias Urbanas, nas quais as tragédias eram encenadas". Esses versos, então, podem ser caracterizados como um comentário extradramático, ou seja, a guerra entre Etéocles e Polinices estaria destoando, na verdade, das Dionísias?

Mastronarde (1994, p.374), por sua vez, observa que o contraste é feito especificamente com Dioniso, porque esse deus foi um dos motivos principais do 
párodo e do $1^{\circ}$ estásimo. É correta tal interpretação, mas lacunar e incompleta, pois dá ensejo a outras perguntas: retroativamente, por que o coro se ocupa tanto de Dioniso? Na verdade, o párodo e o $1^{\circ}$ estásimo tratam de Dioniso, e não particularmente das festas relacionadas a esse deus.

O coro continua nos seguintes termos:

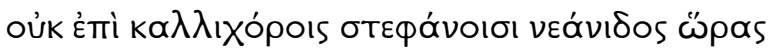

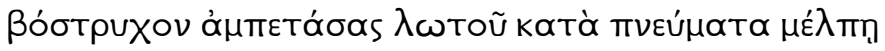

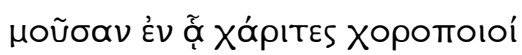

Teu sopro de pífaros destoa das formosas danças

da juventude coroada que revolve os cabelos,

tu não cantas a musa de grácil dança

$(786-8)$

O universo evocado nesses versos está além da narrativa mítica explorada anteriormente. Aqui é feita referência direta a um festival onde predomina o sentimento de júbilo e a atividade de dança, como se pode ver a partir de vocábulos como

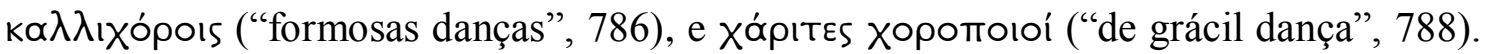
Como foi feita referência às festas de Brômio no verso imediatamente anterior, presume-se que o coro esteja tratando aqui realmente das Dionísias em que As Fenícias foram encenadas.

Dessa forma, o caráter extra-dramático de todos os trechos analisados acima pode ser justificado pela estrofe do $2^{\circ}$ estásimo. O coro, então, não somente exerce a função dramática de "servas de Apolo", mas também a de um grupo cultual de cidadãos (atores) em honra a Dioniso inserido em um festival dionisíaco. 


\section{CONSIDERACÕES FINAIS}

O objetivo do capítulo precedente foi mostrar que existe uma conexão estrutural entre as formas teatrais e ritualísticas na peça As Fenícias. Dado o contexto religioso (i.e dionisíaco) em que ela foi encenada, acredita-se portanto ter-se provado que existe um continuum ritualístico ${ }^{117}$ identitário que se resolve no binômio tragédia-festival. A expressividade ritual exposta nos cantos corais aí analisados pode ser resumida sob dois movimentos principais: 1)aparente ausência de ligação pragmática com o enredo da peça, e 2)força textual para transcender o enredo do drama.

Como resultado, determinados trechos da peça produzem um efeito extradramático: a auto-referencialidade e o "dispositivo de aproximação", unidos em maior ou menor grau, geram a projeção coral. Em outras palavras, de acordo com Bierl (2009, p. 97), “o papel do coro, por conseguinte, progressivamente desaparece por detrás de sua função cultual no aqui e agora [do espectador]”. Se, como visto na

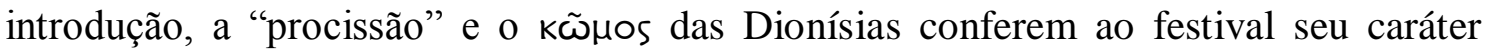
religioso, As Fenícias apresentam elementos que permitem enquadrar também a tragédia nesse universo religioso cultual ${ }^{118}$.

O fundamento de todo esse processo, porém, não podia ser outro que não o mito. Por si só ele realiza a conexão entre o universo do espetáculo e o da religião. Segundo Finley (1965, p.283): “esta era a sua função [do mito], ou melhor, uma de suas funções: tornar o passado inteligível e significativo por seleção e focalização", o que produziria a tríade mito-verdade-religião: "tudo isso era sério e verdadeiro, literalmente verdadeiro. Era a base da religião deles, por exemplo." As Fenícias, portanto, não somente trariam a "seleção e focalização" do Ciclo Tebano na querela entre Polinices e Etéocles, mas representariam a conscientização do fazer mitográfico e o seu consequente uso com finalidade dramática. "Circularidade mítica" e "junção mito-ação" atualizam e potencializam o significado dos eventos (do mito) no presente da ação dramática. A esse

\footnotetext{
${ }^{117}$ Expressão retirada de Bierl (2009, p.267).

${ }^{118}$ Aqui fica o ensejo para se projetar uma futura pesquisa de doutorado: alargar o corpus da pesquisa, englobando todas as peças de Eurípides que tratem direta ou indiretamente de Dioniso, e investigar se esse "universo religioso cultual”, próprio das Dionísias, também estaria presente nelas.
} 
desenvolvimento, por sua vez, sucederia um segundo movimento: os elementos ritualísticos vistos acima atualizariam determinados momentos do drama no presente da performance teatral. Segundo Buxton (1994, p.153), "enredo e festival andam juntos, mesmo que não se tem consciência do papel que a narração do mito tenha exercido no ritual”. É convicção do autor deste trabalho ter-se demonstrado a estrutura funcional da relação mito-ritual em As Fenícias de Eurípides. 


\section{SEGUNDA PARTE:}

\section{TRADUÇÃO}

Apresenta-se aqui a tradução integral da peça As Fenícias, feita segundo texto grego estabelecido por Mastronarde (1994), exceto versos 235 e 1702 - edição de Kovacs (2002).

Esta é uma tradução que se quer voltada para o público acadêmico. Assim, grande parte das notas de rodapé, além de fornecer informações geográficas e históricas (ou míticas), ocupar-se-á com questões próprias da tradução. Em certas ocasiões de hesitação, seja gramatical, seja filológica, foi feito um cotejo entre as traduções e comentários mais recentes da peça.

\section{PRÓLOGO}

Jocasta:

\{Ó tu que, entre estrelas, avanças na estrada

do céu firmado num carro de áureos relevos $\left.{ }^{119},\right\}$

Sol, tu que orbitas tua chama com céleres corcéis,

que raio de desgraça contra Tebas lançaste

aquele dia, quando Cadmo veio até esta terra

depois de deixar o salino chão fenício;

ele outrora desposou Harmonia, filha de Cípris,

e gerou Polidoro, de quem é dito Lábdaco

ter nascido; deste último nasceu Laio.

Sou eu a renomada filha de Meneceu -

\footnotetext{
${ }^{119}$ Texto entre chaves " \{\} ” é julgado inautêntico. Mantivemos os marcadores tais quais expostos na edição de Mastronarde (1994).
} 
\{e Creonte é meu irmão, nascido de mesma mãe.

Chamam-me Jocasta, pois assim meu pai

escolheu. Laio se casa comigo, coabitamos,

e, como o palácio permanecesse sem crianças,

ele parte a fim de indagar e exorar a Febo

uma companhia de meninos para a casa.

O deus responde: "Senhor de Tebas dos belos

corcéis, não semeies filhos contra a vontade divina.

Se de ti nasce um filho, mata-te a ti o progênito,

e toda tua casa em sangue soçobrará."

Devoto aos prazeres, porém, ele sucumbe a Baco

e nos semeia um filho; seara feita, o pai

apercebe-se de seu erro e do vaticínio do deus

e entrega o pequeno a pastores para ser exposto

na campina de Hera $^{120}$, no rochoso Citerão,

perfurando-lhe o tornozelo com ponta de ferro:

por isto toda a Hélade o chama Édipo ${ }^{121}$.

Os cavalariços de Polibo, porém, acolhem

a criança e, levando-a ao palácio, deixam-na

com sua senhora. Esta põe sob seu seio o fruto

doloroso do meu parto e convence o marido ${ }^{122}$.

Chegando à idade viril com fulva barba ${ }^{123}$,

meu filho, por si mesmo ou por outrem instigado,

tencionando conhecer seus genitores,

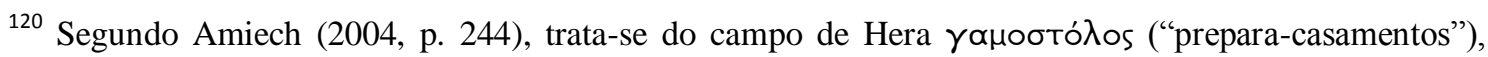
deusa que, sob tal título, era contrária à homossexualidade e que, por isso, estaria desgostosa com Laio por causa do rapto de Crisipo, filho de Pélops (ver "resumo de Pisandro" no capítulo I desta dissertação).

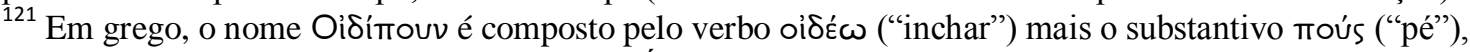
donde vem o significado "pés inchados" para Édipo.

${ }^{122}$ Procedimento semelhante é descrito pelo parente de Eurípides na peça As Tesmoforiantes (502-16) de Aristófanes.

${ }^{123}$ Пupoós, a cor da flama do fogo, é como os gregos tipicamente caracterizam a cor da primeira barba do jovem adulto, cf. Mastronarde (1944, p.154).
} 
vai à morada de Febo, assim como Laio,

meu esposo, procurando saber se a criança exposta

ainda vivia. Seus passos se encontraram

em um ponto da estrada dividida da Fócida,

e o condutor de Laio, então, ordena:

"estrangeiro, abre espaço para o rei passar."

Sem responder, arrogante, continua andando. Os cavalos,

Com seus cascos, ensanguentam-lhe o tendão do pé.

Então - por que falar em males que não estes -

O filho assassina o próprio pai, toma-lhe o carro

e o dá a Polibo, pai nutrício. Como oprimisse a cidade

com assaltos a esfinge, meu marido já morto,

Creonte, meu irmão, então, anuncia-me em núpcias

para quem desvendasse o enigma da sábia virgem ${ }^{124}$ :

a este seria dado meu leito. Ora, deu-se o caso de ser

Édipo, meu filho, quem desvendou os versos da Esfinge:

\{Por isto ele se fez senhor desta terra. $\}$

e o cetro da cidade ele tomou como prêmio.

Sem saber, o infeliz desposa sua genitora,

e a genitora igualmente se junta ao seu filho.

Do filho, gero dois outros filhos homens,

Etéocles e a força gloriosa de Polinices,

e duas meninas: a mais nova, Ismene o pai

nomeia, a mais velha, Antígone chamei.

Descobrindo ter desposado a própria mãe,

\footnotetext{
${ }^{124}$ A "sábia virgem", ou a Esfinge, mencionada acima no verso 46. No segundo estásimo também é

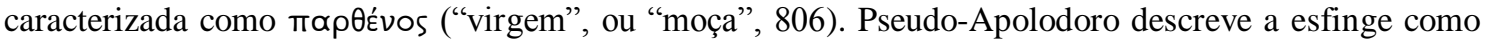

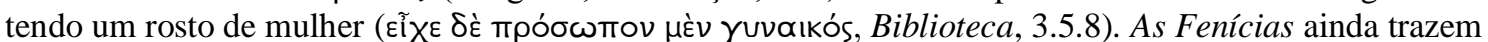
sua genealogia no terceiro estásimo (filha da Terra e de Equidna, 1019-20). Desde Hesíodo ela é conhecida como a ruína dos tebanos (Teogonia, 326). Ainda segundo Pseudo-Apolodoro, o enigma da esfinge era "o que é que, possuindo uma voz, vem a ter quatro pés, dois pés e três pés?" (Tí દ̇otıv ö ríav

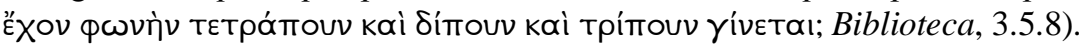


Édipo, suportando toda dor e sofrer,

contra os próprio olhos lança sórdida morte:

com um broche dourado ensanguenta suas pupilas.

Ao se ensombrar o semblante de meus filhos ${ }^{125}$,

eles logo trancam o pai para que o destino,

carecente de muitas explicações, fique esquecido.

Contudo, vivo ainda está em casa. Ensandecido

Com seu destino, impiíssimamente amaldiçoa os filhos:

dividir-se-á esta casa pelo ferro afiado.

Atemorizados ambos de que os deuses cumprissem

tais preces caso continuassem vivendo juntos,

estabelecem o seguinte acordo: Polinices, mais jovem,

exila-se primeiro da terra, voluntariamente,

e Etéocles, permanecendo aqui, retém o cetro,

revezando-o anualmente. Etéocles, porém,

entronado no poder, não cede o seu trono

e como pária destas plagas expulsa Polinices.

Este, indo a Argos, alia-se a Adrasto, reúne

numeroso exército argivo e o traz para cá.

Assim ele chega até esta muralha de sete portas

e reivindica o cetro paterno e sua parte da terra.

$\mathrm{Eu}$, para resolver a discórdia, convenci os filhos

a se encontrarem sob trégua antes de tocarem a lança.

O mensageiro enviado anuncia que ele virá.

Mas, ó tu que habitas as brilhantes alturas do céu,

Zeus, salva-nos, concede a paz aos meus filhos.

Se és sábio, é dever não permitir que um mesmo

homem entre os mortais esteja sempre na desgraça.

${ }^{125}$ i.e. o nascimento da primeira barba, cf. v. 32. 


\section{Pedagogo:}

Antígone, ilustre rebento da casa paterna,

como te foi permitido pela mãe deixar a recâmara

das moças para ir ao cômodo mais alto do palácio, -

90

teus rogos eram para ver o exército argivo -

espera, averiguarei antes que rumo tomar

para não aparecer-nos nenhum dos cidadãos:

maus comentários vêm contra mim, escravo,

e contra ti, senhora; mostrar-te-ei tudo que sei

95

do que vi e ouvi quando estive entre os argivos,

pois lá fui levar proposta de trégua ao teu irmão

valendo ${ }^{126}$ daqui para lá e de lá para cá.

Ora, ninguém da cidade se aproxima do palácio;

sobe toda esta antiga escada de cedro com teu pé;

100

observa a planície e o tamanho do exército inimigo

ao redor das águas correntes do Ismene e do Dirce ${ }^{127}$.

Antígone:

Segure, segure tua velha mão a nova

enquanto por sobre a escada

alço o pé ${ }^{128}$.

\footnotetext{
${ }^{126}$ Este verso indica que a trégua é recíproca entre argivos e tebanos, ou seja, entre Polinices e Etéocles, cf. Mastronarde (1994, p.182). Certas edições, por entenderem que a trégua valia apenas para Etéocles, suprimem este verso.

${ }^{127}$ Os rios Ismene e Dirce são os rios que envolvem a cidadela de Tebas. Adiante, eles serão descritos

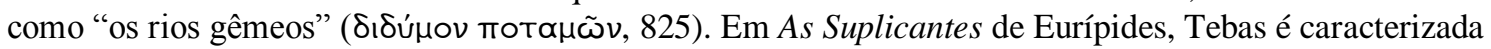

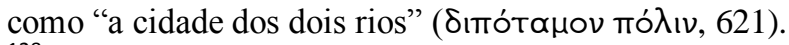

${ }^{128}$ Assim como Jocasta em seu monólogo, a fala do pedagogo está em trimetros jâmbicos. A fala de Antígone, porém, é uma mistura de diversos metros (dócmio, anapesto, crético, etc.). Ver esquema métrico completo em Mastronarde (1994, p.173-5).
} 
Pedagogo:

Aqui, segura, menina; vieste em hora certa:

o exército pelasgo está se movendo,

separando-se em grupos.

Antígone:

Ó senhora filha de Leto,

Hécate $^{129}$, repleta de bronze

a planície reluz.

Pedagogo:

Não é sem relevo que Polinices chega aqui,

blasonando incontáveis soldados, inúmeros cavalos.

Antígone:

Estão os portões bem trancados,

as traves de bronze atadas à marmórea

muralha de Anfião ${ }^{130}$ ?

Pedagogo:

Coragem! Bem protegido se está aqui dentro.

Mas, se queres conhecer o inimigo, olha aquele primeiro.

Antígone:

Quem é esse de clara crista,

à frente conduzindo a coorte,

${ }^{129}$ Sincretismo religioso de Hécate e Ártemis. Na Teogonia (409-10), Hécate não é filha de Leto, mas de Perses e Astéria. Repare-se que Antígone invoca apenas deusas virgens.

${ }^{130}$ Anfião e seu irmão Zeto são, em certas fontes, considerados os fundadores de Tebas (e.g. Odisseia, XI, 260-3). 
um escudo todo brônzeo com seus braços

hasteando?

Pedagogo:

Antígone

Um chefe-de-regimento, senhora.

Quem, de onde é?

Fala, ancião, como ele se chama?

Pedagogo:

Ele é, segundo dizem, de origem micênica,

mas habita as correntes do Lerna ${ }^{131}$; é o senhor Hipomedonte.

Antígone:

Oh! Que altivez, como é terrível de se ver.

A um terrígeno gigante, radiante, assemelha-se,

como nas pinturas - em nada se parece

com os de estirpe efêmera.

Pedagogo:

E não vês aquele que transpõe as águas do Dirce, outro comandante?

Antígone:

O estilo de suas armas é diferente.

132bis

Quem é ele?

Pedagogo:

Tideu, o filho de Eneu,

tem no peito o Ares etólio ${ }^{132}$.

${ }^{131}$ Rio Lerna designa Argos. Há outra referência a esse rio no verso 613. 
Antígone:

Não é ele, ancião, aquele que

se casou com a irmã

da esposa de Polinices ${ }^{133}$ ?

Que extravagante seu armamento, meio bárbaro!

Pedagogo:

Sim, filha, os etólios todos carregam leves escudos

e, com suas lanças, são os lanceiros mais certeiros.

Antígone:

\{Mas, ancião, como sabes tudo isso tão bem?

Pedagogo:

Aprendi observando os emblemas dos escudos,

quando fui levar proposta de trégua ao teu irmão ${ }^{134}$;

Lá tendo os visto, reconheço os combatentes. \}

Antígone:

Quem é aquele que contorna o memorial de Zeto ${ }^{135}$,

de cachos abundantes, jovem de aspecto

e olhar terrível de se contemplar?

\footnotetext{
${ }^{132}$ Etólia, região grega situada na costa norte do golfo de Corinto, a leste da Acarnânia, era conhecida

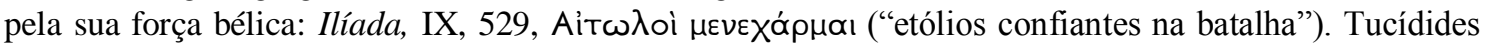
(1.5.6) relata que eles viviam do saque e carregavam armas no dia-a-dia.

${ }^{133}$ Um escólio identifica os nomes das filhas de Adrasto, esposas de Polinices e Tideu: Argeia e Deipile, respectivamente (cf. Amiech (2004, p.274)). Polinices relatará depois também a história desse casamento nos versos 417-23.

${ }^{134}$ Repetição verbatim do verso 97 . Modificamos, porém, ligeiramente a tradução.

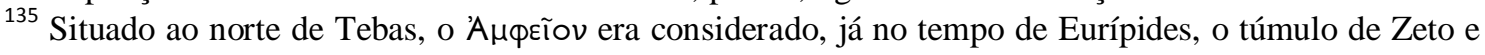
Anfião, cf. Mastronarde (1994, p.193). Ver Pausânias 9.17.4.
} 
Um comandante, já que, atrás dele, um exército

de todas as armas o acompanha?

Pedagogo:

Este é Partenopeu, de Atalante nascido.

Antígone:

Que Ártemis das montanhas, com sua mãe ${ }^{136}$,

domine-o e o perca com sua flechas,

ele que veio destruir minha cidade.

Pedagogo:

Assim seja, filha, mas a justiça está do lado deles;

temo que os deuses reparem nisso com exatidão.

Antígone:

Onde está aquele que comigo nasceu da mesma mãe

para um penoso destino?

Caríssimo, fala, onde está Polinices, ancião?

\section{Pedagogo:}

Ele está próximo ao túmulo das sete virgens

De Níobe ${ }^{137}$, posicionado ao lado de Adrasto.

Estás vendo?

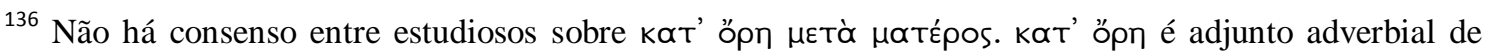

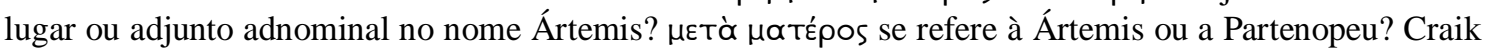
(1988, p.71) traduz por "on the mountains with his mother" (i.e. mãe de Partenopeu); Kovacs (2002, p.227) traduz por "[may Artemis] of the mountains [destroy him], and his mother with him"; Amiech (2004, p.131) prefere "[Puisse Artémis] qui s'élance par les montagnes aux côtés de sa mère", e Medda (2006, p.135): "[Artemide] che con sua madre vive sui monti”.

${ }^{137}$ Segundo Pausânias (9.16.4), o túmulo das filhas de Níobe se localizava próximo ao Portão Prétide (ver verso 1109). Níobe era esposa de Anfião.
} 
Antígone:

Não o vejo com clareza, mas, de certo modo, vejo

$161 \mathrm{bis}$

os contornos de sua forma, um tronco assemelhado.

Pudera eu com meus pés transpor, pelo ar,

o caminho das nuvens de vento

até meu irmão; lançar-me-ia, então,

nos seus braços, no seu pescoço querido.

Triste degredo o seu.

Proeminente em suas armas douradas, ancião,

ele rebrilha tal qual os raios do sol auroreal.

Pedagogo:

Ele virá ao palácio, grande júbilo para ti ${ }^{138}$,

sob salvo-conduto.

Antígone:

E aquele, ancião, quem será?

$171 \mathrm{bis}$

Aquele que, de pé, conduz um carro branco?

Pedagogo:

Eis Anfiarau ${ }^{139}$, senhora, o nigromante:

com ele vêm as vítimas da Terra sedenta de sangue.

Antígone:

Ó progênie do Sol ${ }^{140}$ de luzidia cintura,

\footnotetext{
${ }^{138} \mathrm{O}$ encontro entre Polinices e Antígone, porém, será proibido por Etéocles $(377-8,616)$.

${ }^{139}$ Eurípides compôs duas tragédias sobre o filho de Anfiarau, Alcmeão: Alcmeão em Psofis e Alcmeão em Corinto (ambas fragmentárias). Alcmeão, assim como seu pai, também lutou contra Tebas na guerra liderada pelo filho de Polinices.

${ }^{140}$ Em Hesíodo (Teogonia, 371), a Lua é irmã do Sol.
} 
Lua, luz de círculo dourado,

com calma e controle a vergasta

nos potros ele aplica, retifica sua rota.

E aquele que ultraja a cidade terrivelmente,

Capaneu, onde está?

180

Pedagogo:

Este avalia as vias de acesso,

180bis

medindo nossos muros de cima a baixo

Antígone:

Ó Nêmesis, barítonos trovões de Zeus

e refulgente brilhar do relâmpago, és tu

quem extirpas o excessivo orgulho.

É este quem diz

que, cativas, dará as tebanas

às micênicas damas e ao tridente de Lerna ${ }^{141}$,

lançando sobre elas servidão

às águas de Posídon e Amimone ${ }^{142}$.

Jamais, jamais, senhora Ártemis,

filha de Zeus dos louros cabelos,

padeça eu dessa escravidão.

\section{Pedagogo:}

Filha, vai para casa, fica dentro do palácio,

nos teus aposentos, já que te satisfizeste

de tudo aquilo que querias observar.

Um tropel de mulheres se dirige ao palácio,

${ }^{141}$ O rio Lerna teria se originado a partir de um golpe do tridente de Posídon.

${ }^{142}$ Amimone era o nome da principal nascente do rio Lerna. 
e a cidade tumultua toda em desordem.

O gênero feminino é amante do maldizer:

se tratam de assuntos pequenos e reles

elas os fazem enormes: é um prazer

para as mulheres falar mal umas das outras.

\section{PÁRODO}

Coro:

O tírio pélago deixando, vim,

primícias a Lóxias,

da ilha ${ }^{143}$ Fenícia;

serva do templo de Febo ${ }^{144}$,

onde sob o cume nevado

do Parnaso ele fez morada,

pelo Jônico ponto em naus

naveguei, enquanto pelo estéril

plano cercado de águas da

Sicília $^{145}$, Zéfiro ${ }^{146}$ cavalgava $^{147}$

\footnotetext{
${ }^{143}$ Importa notar que nesta peça, para Eurípides, a Fenícia é uma ilha. No prólogo (6), essa região é caracterizada como éva $\lambda \lambda_{i ́ \alpha} v$ X $\theta$ óva, ou seja, "terra do mar", sinônimo para ilha (cf. Liddell). Mastronarde (1994, p.215) informa que "Tiro foi uma ilha até ser unida ao continente por um dique durante o cerco de Alexandre em 332 a.C".

${ }^{144} \Phi o i ́ \beta \omega$, o orignal grego traz um dativo e Medda (2006, p.141) mantém em sua tradução o aspecto primeiro do caso dativo ("ancella del tempio per Febo"). Contudo, ver comentário de Mastronarde (1994, p.215) sobre esse "incomum dativo".

${ }^{145}$ Estranhamente, Eurípides traça a rota Fenícia-Tebas passando pela Sicília, no "mar jônico". Hoje entenderíamos que o caminho mais óbvio seria entrar na Grécia pelo mar Egeu. Craik (1988) enumera três sugestões já feitas para solucionar esse problema: a)a ilha Fenícia referida pelo coro seria, na verdade, Cartago; b)o "mar jônico" seria o mar que iria da Jônia até a Eubeia, e Sicília seria uma ilhota entre Cálcis e Áulis; c)o "mar jônico", na verdade, seria o mar egeu. Sabe-se que Páris teria passado em Sídon em sua volta da Grécia com Helena (Il. 6.289-92).
} 
com seus ventos e produzia

o mais belo murmúrio no céu ${ }^{148}$.

ant.1

Pela minha pólis eleita

a mais bela oferta a Lóxias,

vim à terra dos cadmeus ${ }^{149}$,

dos famosos agenoridas ${ }^{150}$

parente $^{151}$, enviada aqui

às torres de Laio.

Igual a ofertas lavradas em ouro

tornei-me acólita de Febo:

ainda as águas de Castália

esperam-me para a delicadeza

virginal dos meus cabelos lavar ${ }^{152}$

nos serviços de Febo.

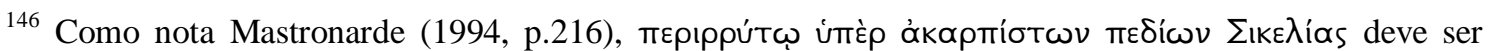

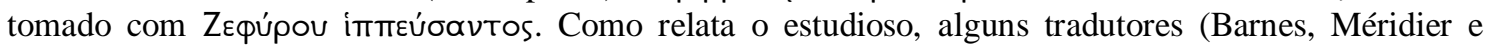
Craik), ao contrário, tomaram essa frase com $\pi \lambda \varepsilon$ ú $\alpha \sigma \alpha$. Podemos acrescentar a essa lista a tradução brasileira de Schüler (2005): "naveguei para além das planícies estéreis / nas águas que banham Sicília". Não é o caso, por exemplo, de Medda (2006, p.141) que assim traduz o trecho: "al soffio di Zefiro che galoppava / sopra le piane infeconde / che battono di flutti la Sicilia".

${ }_{147}$ Para alusão a uma antiga crença que relaciona os deuses-ventos a cavalos, ver Mastronarde (1994, p.218).

${ }^{148}$ Como vemos no original, esta estrofe só apresenta ponto final em depois de sua última palavra. Na tradução, mantivemos essa dicção. Mastronarde (1994, p214) explica que estrofes líricas assim são características do estilo ditirâmbico tardio de Eurípides.

${ }^{149}$ Antonomásia para gentílico "tebano" utilizado desde Homero (Od. XI, 276). Curioso notar que, nem por isso, Cadmo sempre tenha sido considerado o fundador de Tebas - o próprio Homero atribui a fundação da cidade a Zeto e Anfíão (Od. XI, 262-3). Ésquilo também se valeu da mesma antonomásia (Set. 39), assim como Sófocles (Oed.Tyr. 1).

${ }^{150}$ Eurípides aqui apresenta Cadmo apenas como pertencente à linha genealógica de Agenor (assim como em 291). Heródoto (IV. 147. 4) é mais detalhista mostrando a relação de pai e filho entre os dois: Kóduos ràp ó Ayrívopos. Eurípides, porém, em outra peça mostra Cadmo como filho de Agenor (Phrixos B fr. 819).

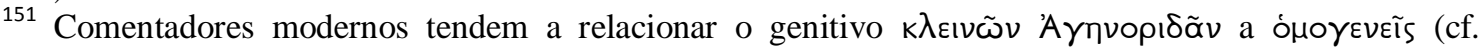

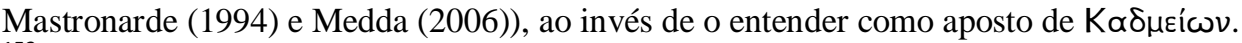

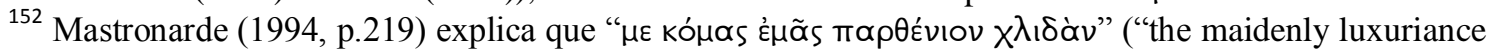
of my hair") é a perífrase tipicamente lírica para se dizer simplesmente "my luxuriant hair". Mantivemos na tradução a perífrase por se tratar de uma tradução acadêmica. 
Ó rocha que acende com o fogo

uma chama dúplice sobre os cimos ${ }^{153}$

báquicos de Dioniso,

e a vinha que dia-a-dia

goteja $^{154}$, o frutuoso cacho

produzindo de sua flor ${ }^{155}$,

e a sacra gruta da serpente,

as alturas vigilantes dos deuses

E ó sagrado monte nevado ${ }^{156}$,

quisera eu ser, sem medo, o coro

dançante do deus para os imortais ${ }^{157}$,

junto aos vales de Febo, umbigo do mundo,

Deixando o Dirce.

str.2

Eis diante das muralhas

vindo impetuoso Ares

que inflama banho de sangue adverso

contra a cidade - tal não ocorra!

\footnotetext{
${ }^{153}$ Eurípides alude aqui Fedriades, "os dois penhascos de Parnaso onde aconteciam rituais báquicos noturnos", cf. Medda (2006, p.145). Arthur (1977, p.167) nota que a adoração a Dioniso em Delfos era mais branda e moderada.

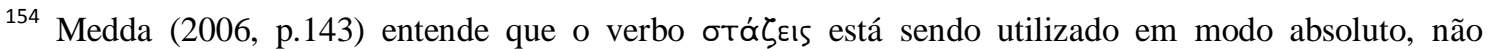
podendo reger $\beta$ ó $\tau$ pvv.

${ }^{155}$ Mastronarde (1994, p.220) sugere a tradução "vine, which daily drips (wine?) or grows ripe (?), putting forth (every day) the full-fruited grape-cluster from the grape-blom", mas logo ressalta que, apesar da inteligibilidade da sintaxe dessa oração, seu sentido é obscuro a nós, mas talvez não para a sua audiência que devia conhecer uma vinha mágica que produziria todo dia cachos novos de uva que se transformariam rapidamente em vinhos.

${ }^{156}$ Os versos 232-34 se referem à caverna Corícia habitada anteriormente pela serpente Píton e à Colina do Arqueiro, de onde Apolo atirou sua flecha para matar aquela serpente, cf. Medda (2006, p.144).

${ }^{157}$ A edição de Mastronarde (1994, p.222), que traz o grego ờ $\theta$ avó Tas $\theta \varepsilon \circ$ ũ, enumera três possibilidades de identificação para essa deusa: a)Ártemis, irmã de Apolo, aceita pela maioria dos estudiosos; b)Atena, cultuada em Delfos como "Pronaia", e c)Gaia, aceita por Craik (1988, p.185), refutada por ele. Ulizamos aqui a edição de Kovacs (2002) e argumentamos que o deus a quem o coro se refere é Dioniso - ver seção 2.4 desta dissertação.
} 
comum é a dor entre amigos,

comum será a dor, se algo sofre

esta terra de sete torres,

à terra fenícia. Ai, ai!

Comum é o sangue, comum

a cria gerada da cornífera Io $^{158}$,

cujas dores me são presentes.

ant.2

Em torno da cidade, uma nuvem

de escudos, densa, se inflama

figura de batalha de morte,

que Ares $^{159} \operatorname{logo}$ testemunhará,

aos filhos de Édipo trazendo

as penas das Erínias.

Ó pelasgo $\operatorname{Argos}^{160}$,

temo a tua força

e a provinda de deus: não é injusto que

à luta se lance o filho armado

que vem reconquistar sua casa ${ }^{161}$.

\footnotetext{
${ }^{158}$ Io, filha de Ínaco, é geralmente associada a Argos, como se lê, por exemplo, em Heródoto (I.1). Segundo o historiador, ela teria sido raptada pelos fenícios e levada ao Egito. É após esse incidente que os cretenses vão a Fenícia e raptam Europa, irmã de Cadmo. Ésquilo menciona que ela teve um filho de Zeus, Épafo(Prom. 850-3), a quem o coro de fenícias mais tarde invocará (676-7) como deidade. Dele viria uma filha, Líbia, de quem nasceria Agenor, ou seja, a terceira geração de Io (Cadmo seria a quarta). Essas últimas informações, porém, são de Pseudo-Apolodoro (Biblioteca, 2.1.4). O coro mencionará Io novamente em 828-9, aí explicitando ter sido quem gerou os reis dos cadmeus.

${ }^{159} \mathrm{O}$ coro contará depois a história do dragão de Ares que Cadmo matou (656-75), donde se iniciou o ódio daquele deus pelo fundador de Tebas, conforme explicado por Tirésias (934).

${ }^{160}$ Coro aqui faz uma contraposição gentílica entre as duas cidades combatentes. Enquanto Tebas foi sempre relacionada a Fenícia, a conexão de Argos é feita com os Pelasgos.

${ }^{161}$ Para Arthur (1977, p.166), a diferença métrica entre o primeiro par estrófico (dímetro coriâmbico) e o segundo (trocaicos), são reflexo dos temas nelas desenvolvidos: o primeiro par trata da paz do santuário de Delfos, enquanto o segundo trata do estado belicoso de Tebas. A tradução não capta tal nuance.
} 


\section{$1^{\circ}$ EPISÓDIO}

Polinices:

As trancas dos sentinelas me permitiram

facilmente chegar ao interior dos muros.

Temo ser capturado aqui por alguma rede

e não conseguir sair de corpo ileso.

Por isso é preciso ter o olhar em toda parte,

aqui e ali, evitando qualquer armadilha.

Armada a minha mão com esta espada,

forneço-me como garantia a minha coragem.

Oh! Quem vem lá? Ora, ruídos agora temo?

Sim, ao que ousa, tudo lhe parece terrível

quando o seu pé adentra solo inimigo.

Fio-me e não me fio em minha mãe

que me persuadiu a vir aqui sob trégua.

Mas eis meu socorro, os altares ${ }^{162}$ próximos

estão, e o palácio ${ }^{163}$ não se encontra ermo.

Vamos, vou por a espada no escuro da bainha ${ }^{164}$

e perguntar a estas recostadas na casa quem são:

mulheres estrangeiras ${ }^{165}$, dizei, de que pátria

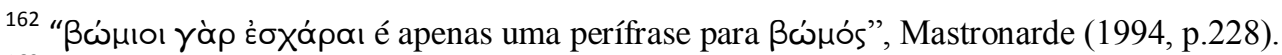

163 Craik (1998) traduz por "shrines", tradução que é refutada por Mastronarde (1994, p.288). Medda (2006) traduz por "casa" - "la casa non è deserta".

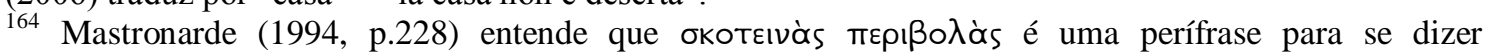

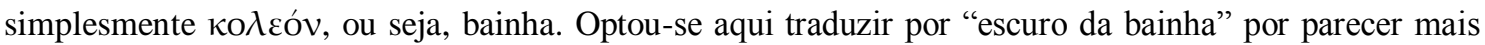
poético, que é a opção também da tradução de Medda (2006), "riponiamo la spada nell'oscurità del fodero". 
viestes para se aproximar a uma casa grega?

Coro:

A terra fenícia foi a pátria que me criou,

e os filhos dos filhos de Agenor me enviaram

a Febo como primícias de guerra.

Ínclito filho de Édipo estava para me enviar

ao sacro oráculo e ao altar de Lóxias,

mas então os Argivos vieram atacar a cidade.

Agora, responde-me: quem és tu que vieste

às muralhas de sete bocas da terra Tebana?

Polinices:

Meu pai é Édipo, o filho de Laio,

e Jocasta me gerou, a filha de Meneceu.

Chama-me o povo tebano de Polinices.

Coro:

Ó parente dos filhos de Agenor ${ }^{166}$

tiranos meus que cá me enviaram -

Diante de ti eu me ponho de joelhos, senhor,

reverente ao costume de minha casa.

Finalmente ${ }^{167}$ voltas a terra pátria.

Ó, senhora, vem ao átrio frontal,

abre as portas!

${ }^{165}$ Uma vez que Polinices identifica essas mulheres como estrangeiras antes mesmo de elas falarem, assume-se que o que lhe permite fazer tal julgamento seja o vestuário delas, exótico ao olhar grego. Ver Mastronarde (1994, p.228) e Medda (2006, p.149).

${ }^{166}$ É curioso que o coro ressalte a progenitura de Édipo e seus filhos a Agenor, não a Cadmo (cf. 219). Em As Bacantes (1305), a versão do mito da fundação de Tebas utilizada por Eurípides diz que Cadmo não teve filhos homens. Aqui, porém, sabe-se, pelo prólogo (8), que Cadmo gerou Polidoro, o bisavô de Édipo.

${ }^{167}$ Mastronarde (1994, p.232): “'at last', as typically in reunion-scenes”; Medda (2006, p.151): "infine”. 
Ouves-me, mãe genitora deste?

Por que tardas a vir do interior

para fora abraçar teu filho ${ }^{168}$ ?

Jocasta:

Um rumor fenício ${ }^{169}$

301

ouvi, jovens, e com meus pés

senis arrasto meu passo trêmulo.

Ó filho, depois ${ }^{170}$ de tanto tempo,

dias incontáveis, revejo teu olhar.

Envolve com teu abraço

o seio de tua mãe,

o meu rosto com

os escuros cachos ondulados

308bis

do teu cabelo, sombreando meu colo.

Ai! É a custo que apareces,

inesperado, imprevisto ${ }^{171}$, aos braços da mãe.

Que dizer de ti? De que modo,

com as mãos e com palavras

o prazer dessa dança confusa ${ }^{172}$-,

Para lá e para cá -,

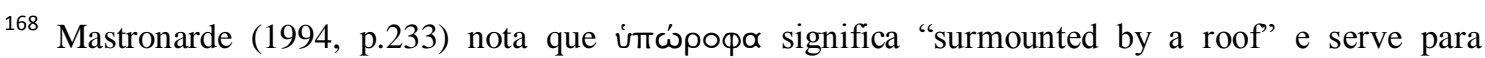
contrastar o interior do exterior. Para manter esse contraste preferimos a tradução "do interior para fora",

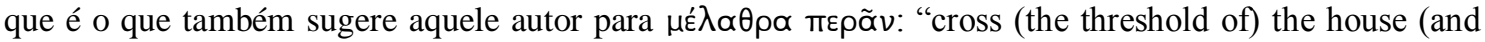
come out)".

169 O primeiro sentido para ßoòv seria "grito", mas Mastronarde (1994, p.237) nota que aqui ßod̀v significa apenas um "som indistinto".

${ }^{170}$ Para Év com sentido de "depois", ver Mastronarde (1994, p.238).

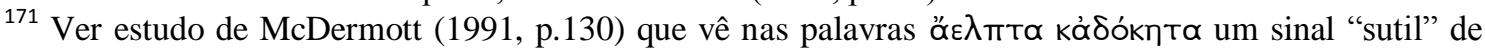
que o encontro entre Polinices e Jocasta também é inesperado de acordo com a tradição mítica.

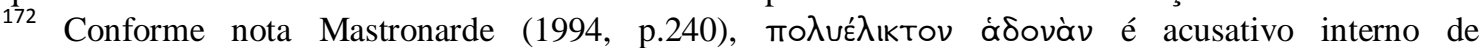

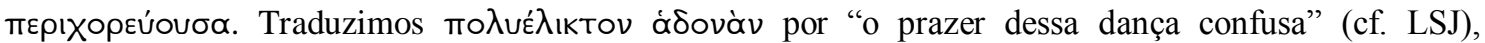
enquanto que Mastronarde prefere "many turns that bring me pleasure", e de modo semelhante também traduz Medda (2006, p.153): "nel piacere di molti giri”. Assim como os versos 306-9, 312-16 também é objeto de longa discussão.
} 
dançando ${ }^{173}$, sentir aquela alegria primeva?

Ai, filho,

deixaste erma a casa paterna

como êxule, expulso e ultrajado pelo irmão,

e os amigos têm saudade,

Tebas tem saudade.

Meus cabelos brancos eu corto,

lacrimosa os oferto pelo meu sofrer,

desfeita $^{174}$ de meu vestido branco, filho,

nestes negros trapos

cinjo-me de sombra ${ }^{175}$.

Em casa está o ancião sem visão,

por conta do par de irmãos

desentravado de casa,

imerso ele está em saudade lacrimal;

ele cisma agora com o suicídio -

ou com a espada,

ou estrangulando-se em casa -

e lamuria imprecações contra os filhos.

Em assíduos brados de ais

a escuridão ${ }^{176}$ o guarda.

Mas de ti, filho, ainda ${ }^{177}$ ouvi que,

\footnotetext{
${ }^{173}$ Como entender que aqui Jocasta esteja dançando, se em 302-3 Jocasta de seus "pés senis" que tem de arrastar até chegar ao lugar onde se encontra o coro? "Esta dança não precisava ser tão vivaz a ponto de parecer incongruente com 302-3", Mastronarde (1994, p.241).

${ }^{174}$ Mastronarde (1994, p.241) atenta que, para o $\tau \varepsilon$ de 322 esperava-se um outro $\tau \varepsilon$ em 325, formando-se assim um par de expressões para o sofrimento de Jocasta. Entretanto, o que se vê em 325 é um ' $\delta$ ', "uma resposta irregular, um contraste irregular", que o autor caracteriza como um forte anacoluto, que tentamos manter nesta tradução.

${ }^{175} \alpha \mu$ pí, conforme nota Mastronarde (1994, p.243) tem um sentido adverbial "around my body".

${ }^{176}$ Mastronarde (1994, p.245) traz okótıa como acusativo interno/adverbial e sugere a tradução "in the darkness (of his closed rooms)". Medda (2006, p.155) traduz por "resta nascosto nell'oscurità".

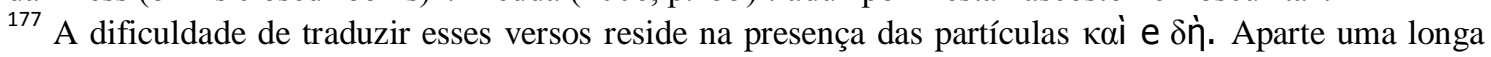
discussão sobre a elisão delas em diversas edições, esta tradução se ateve ao comentário de Mastronarde
} 
jungindo-te em matrimônio, gozaste

da paternidade em casa estrangeira,

agraciado por aliança estrangeira,

dor insuperável para a mãe e

para vetusta linhagem de Laio,

ruína de um casamento externo.

Eu não acendi para ti a chama,

costume matrimonial,

como convém a uma mãe feliz,

sem cantos e sem o mimo de sua água

o Ismeno foi padrinho, e na tebana

cidade o ingresso da noiva foi silenciado ${ }^{178}$.

Pereça, seja o ferro,

a cólera, ou teu pai, a causa disso,

seja o deus que perdeu

a casa edipiana.

A tribulação desses males sobre mim caiu.

Coro:

O gerar pela dor é tremendo nas mulheres,

e toda estirpe feminil adora seus filhos.

\section{Polinices:}

Mãe, foi inteligência minha vir até meus inimigos -

E também desinteligência. É forçoso a todos

amar a pátria. Quem discorda disso

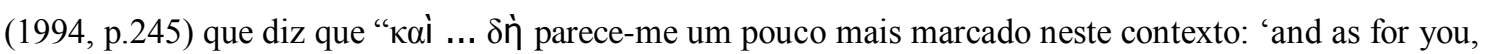
child, i hear that (in addition to your abscence from us in exile) you are even married"'.

${ }^{178}$ Era um costume matrimonial a mãe acender tochas aos filhos nubentes. Na peça Medeia de Eurípides, Medeia se lamenta não poder acender, no futuro, a tocha a seus filhos (1027). Além disso, segundo Kovacs (2002, p.245), durante a cerimônia de casamento, a mãe deveria providenciar um banho ritual para o filho, por isso a referência às águas do rio Ismeno. 
discorda por $\operatorname{prazer}^{179}$, pois a mente está nela.

De tal modo alarmado aqui cheguei, com medo

de que algum embuste de meu irmão me mate,

que ando pela cidade olhando tudo ao redor,

espada a mão. Uma só realidade me vale,

a trégua e a tua garantia que me faz reconduzir

aos muros pátrios. Eis que flébil eu aqui chego:

finalmente revejo o palácio e dos deuses as aras,

o ginásio onde fui criado e as águas do Dirce.

Injustamente expatriado, o estrangeiro

habito com um olhar lacrimoso no rosto.

Mas, de uma dor vem outra dor, vejo-te

com a cabeça raspada, em atro manto

vestida, ai de mim, desgraçado que sou!

Como é terrível, mãe, a inimizade familial

e a reconciliação que acarreta dissolução ${ }^{180}$.

Que faz o ancião meu pai em casa

contemplando a escuridão ${ }^{181}$ ? E as duas irmãs?

Certo gemem as coitadas meu exílio?

Jocasta:

Desgraçadamente um deus ${ }^{182}$ rui a estirpe edipiana.

\footnotetext{
${ }^{179}$ Mastronarde (1994, p.250): “delights in (insincere) disputation”. Polinices ataca aqui o discurso sofístico, como fará também adiante (469-72).

${ }^{180}$ Para o verso 375, seguimos a sugestão de Mastronarde (1994, p.254): "reconciliations that entail difficult dissolution < of hatred>". Na verdade, esse mesmo autor enumera um série de dificuldades desse verso, principalmente por causa dos múltiplos significados de $\delta v \sigma \lambda$ útous e da forma incerta (dos manuscritos) de $\varepsilon \chi 0 v \sigma \alpha$. Craik (1988, p.83) traduz simplesmente por "and how hard to reconcile", e Medda (2006): "quanto sono difficili le riconciliazioni”. Ademais, como notado por Mastronarde e Craik, em muitas edições esse verso foi deletado.

${ }^{181}$ Mastronarde (1994, p.256) nota que бкótos tradicionalmente vinha aos olhos da pessoa somente no instante de sua morte. Assim, Édipo é aqui caracterizado como um ser quase morto. $\mathrm{O}$ autor sugere duas possíveis traduções: "whose glance hits darkness" ou "whose glance is darkness". Optamos pela primeira, e Medda (2006, p.159), pela segunda: "col suo sguardo di tenebra".

${ }^{182}$ Ver versos 352-3 onde Jocasta se pergunta de onde vem a ruína de sua família.
} 
Assim ele começou: eu gerei contra a lei,

desgraçadamente teu pai desposou e tu nasceste ${ }^{183}$.

Mas por que isso? Força é acatar os deuses.

Perguntar-te o que desejo, mas te incomodar

temo, é para isso que vim ${ }^{184}$ até aqui ${ }^{185}$.

Polinices:

Indaga então, não deixes nada faltar:

o teu querer é o meu querer, mãe.

Jocasta:

Primeiro então pergunto o que quero saber:

privar-se da pátria, é isso um grande mal?

Polinices:

O maior deles! Pior do que as pessoas falam.

Jocasta:

Como assim? Que há de difícil ao exilado?

Polinices:

Algo dificílimo, não poder discursar livremente.

Jocasta:

Algo próprio do escravo, não falar o que se pensa.

\footnotetext{
${ }^{183}$ Os versos 380-1 são bastante elípticos. Seu sentido integral é: "contra a lei [porque Laio havia sido proibido por Apolo] eu gerei [Édipo], Édipo se casou [comigo], e tu nasceste [para nós]", ver Mastronarde (1994, p.257).

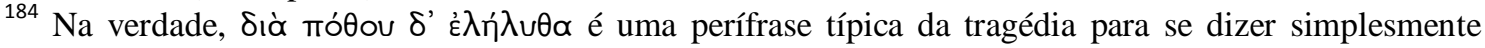

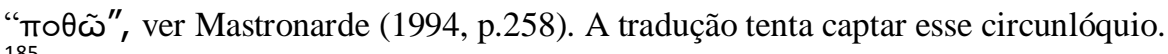

${ }^{185}$ Para que essa fala de Jocasta fizesse sentido nesta tradução, invertemos a estrutura sintática original desses versos. Mesmo no grego, a estrutura está embaraçada, como aponta Mastronarde (1994, p.257): “a expressão de hesitação é reforçada pelo entrelaçamento das orações".
} 


\section{Polinices:}

E ainda suportar o desatino dos poderosos...

Jocasta:

Também isto é difícil, participar da inépcia dos ineptos...

Polinices:

Mas para ganhar, precisava, contrário a índole, servir.

Jocasta:

As esperanças, porém, nutrem os exilados, é o ditado.

Polinices:

Têm, certamente, bela aparência, mas sempre tardam.

Jocasta:

E o tempo não provou serem elas ilusórias?

Polinices:

Elas têm um encanto de Afrodite pelos males ${ }^{186}$.

Jocasta:

Onde comias antes de ganhares a vida casando-te?

\footnotetext{
${ }^{186}$ Conforme se anunciava desde o verso 397, aqui também se confere o "caráter de atração erótica" às esperanças. $\mathrm{O}$ verso, na verdade, é de difícil tradução, e se transmitiu possivelmente com corrupção. Craik (1988, p.85) traduz por "They have a certain lovely charm in misfortune", e Mastronarde (1994, p.262) sugere "hopes have a certain sweet compulsive desire for evils". Preferimos aqui manter a palavra Afrodite, como no original, e entendemos ka $\kappa \omega \nu$ como Mastronarde, ou seja, "um genitivo objetivo normal, referindo-se não aos males do exílio, mas aos males que aparecem com uma esperança ilusória". Para discussão completa, ver referência a Mastronarde citada acima.
} 
Polinices:

Um dia eu tinha o bastante na mesa, o outro não.

Jocasta:

Os amigos de teu pai, os estrangeiros não te ajudaram?

Polinices:

Tenha boa sorte ${ }^{187}$ : a amizade nada vale, se estás desgraçado.

Jocasta:

Mas teu bom nascimento não te pôs em altos lugares?

Polinices:

O mal é não ter posses: minha linhagem não me nutriu.

Jocasta:

A pátria, como parece, é o bem mais caro aos homens.

Polinices:

Nem poderias ${ }^{188}$ dizer em palavras o quanto é caro!

Jocasta:

Como foste a Argos? Que tinhas em mente?

Polinices:

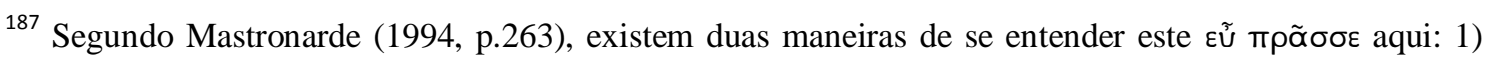
"tenha sempre boa sorte (sc. se você quiser que os amigos lhe deem atenção)", e 2)"boa sorte a você (sc. que é tão ingênuo a ponto de pensar que os amigos de meu pai me ajudaram)". Para o autor a primeira é a correta, porém traduzir toda essa ideia em um verso que não fique muito longo é impossível. Mesmo Medda (2006, p.163), que fez sua tradução em prosa, não transmite integralmente todo o sentido de $\varepsilon \tilde{u}$ пра̃ $\sigma \sigma \varepsilon$ ("vedi di aver sempre fortuna").

${ }^{188}$ Segunda pessoa "indefinida", ver Mastronarde (1994, p.264). Medda (2006, p.163) traduz diretamente como "non si potrebbe". 
Lóxias proclara a Adrasto um certo oráculo.

Jocasta:

Qual? Sobre o que estás falando? Não entendo.

Polinices:

Unir em casamento as filhas com um porco e um leão.

Jocasta:

E que tem teu nome a ver com essas bestas?

Polinices:

Não sei, mas o nume me chamou à minha sorte.

Jocasta:

Sábio é o deus. Como conseguiste casamento?

Polinices:

Era noite, e eu entrei no átrio de Adrasto.

Jocasta:

Buscavas pernoite, como todo êxule que vaga?

Polinices:

Sim, isso mesmo, e outro êxule a nós se juntou.

Jocasta:

Quem era esse? Decerto um outro mísero. 
Polinices:

Tideu, aquele que dizem ter nascido do pai Eneu.

Jocasta:

E por que Adrasto vos comparou a feras?

Polinices:

Porque contendemos a respeito de um leito.

Jocasta:

Assim o filho de Talau entendeu o oráculo?

Polinices:

E a nós dois ele então concedeu duas jovens.

Jocasta:

E és tu feliz com esse casamento, ou infeliz?

Polinices:

Não temos nenhuma censura até o momento.

Jocasta:

E como convenceste o exército a te seguir até aqui?

Polinices:

Aos seus dois genros Adrasto jurou isto:

\{a Tideu e a mim, concunhados somos\}

a ambos reconduzir a pátria, primeiro a mim.

Numerosos argivos e micênicos, os melhores, 
estão aqui comigo - dura dádiva que recebo,

mas necessária. Lidero um exército contra minha

cidade. Juro pelos deuses - eu, de mau grado

ergo a lança contra os meus - eles, de bom grado.

compete a ti a cessação ${ }^{189}$ desses males,

mãe, reconciliando os de mesmo sangue,

e encerrando a dor minha, tua e de toda cidade.

Há muito se repete este ditado ${ }^{190}$, e digo aqui de novo:

a riqueza, para os homens, é a honra máxima,

e o maior poder, entre os homens, ela possui.

Em busca dela venho, trazendo lanças

incontáveis: se pobre, o bem-nascido é um nada.

Coro:

Também Etéocles para a reconciliação

aqui vem ${ }^{191}$. A ti, Jocasta mãe, cabe falar

as palavras com as quais reconciliarás os filhos.

\section{Etéocles:}

Mãe, aqui estou: vim em teu favor ${ }^{192}$.

\footnotetext{
189 Aqui a fala de Polinices assume uma terminologia jurídica e diplomática, cf. Mastronarde (1994, p.269). $\delta$ ı́́ $\lambda$ voıs, por exemplo, só ocorre duas vezes em todos os textos trágicos que nos restaram, por isso escolhemos traduzi-la por uma palavra de caráter também jurídico e diplomático.

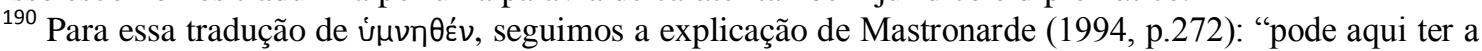
conotação de 'mencionado com aprovação, estima, ou admiração', mas significa sobretudo 'pronunciado em repetição (ritualística)"”.

${ }^{191}$ A didascália da peça informa que Etéocles entra com dois serviçais, ver Medda (2006). Se assim for, nesta cena teremos mais de três atores (Polinices, Etéocles e Jocasta), embora esses serviçais não tenham fala.

${ }^{192}$ Interessante é a nota de Mastronarde (1994, p.274) a respeito da posição do pronome ool. O estudioso descarta a possibilidade de que tal pronome esteja em posição de ênfase, donde viria a tradução "em deferência a ti, [não a Polinices]" - nesse caso бol deveria ser a primeira palavra da oração. Assim como está, Mastronarde prefere entender a sentença como "apenas como um favor". Observando as traduções mais modernas da peça, divergências são notadas exatamente entre essas duas acepções. A tradução brasileira de Schüler (2005), por exemplo, opta por aquela primeira alternativa ("Em atenção a ti é que vim"), já a italiana de Medda (2006), opta pela segunda ("sono venuto per farti il favore che mi ha chiesto").
} 
Que se deve fazer? Que alguém inicie o discurso.

Ao redor dos muros <

$$
>{ }^{193} \text { e dos pares do exército }
$$

parei de comandar os cidadãos ${ }^{194}$ para ouvir

de ti os juízos comuns com os quais, persuadindo-me,

trouxeste este homem muro adentro sob trégua.

Jocasta:

Tem-te, Etéocles! A pressa não produz justiça,

e sobretudo os calmos discursos geram algo sábio.

Relaxa este terrível olhar e este respirar irado.

Não vês a cabeça sem pescoço de uma

górgona, mas vês teu irmão recém-chegado.

E tu, por tua vez, torna a face para teu irmão,

Polinices - olhando ambos ao mesmo ponto

conversarás melhor e serás receptivo a ele.

Desejo aconselhar algo sábio a ambos:

quando alguém se zanga com um amigo

e, encontrando-o, encara-o olho no olho,

é mister ater-se somente no motivo do encontro

e não fazer menção alguma de um mal passado.

A palavra primeiro a ti, Polinices, meu filho:

és tu que trazes o exército dos dânaos,

como dizes, ofendido; que um dos deuses

seja juiz e mediador dessas ofensas.

Polinices:

\footnotetext{
193 Os marcadores “<>” indicam que o texto está omitido na fonte e pode ter sido preenchido ou deixado incompleto pelos editores. Neste caso, Mastronarde (1994) o deixou incompleto.

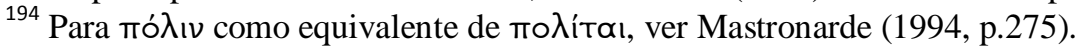


Direto o linguajar da verdade se fez,

e a justiça ${ }^{195}$ não precisa de múltiplas interpretações:

em si é oportuna. Já o discurso injusto,

em si doente, usa de sofismas como remédio.

Eu prestei atenção a ambos nossos interesses

pela casa paterna ${ }^{196}$ e pretendi escapar

das pragas que Édipo então nos rogou.

E eu mesmo de bom grado saí desta terra

cabendo a ele governar a pátria no ciclo de um ano

para eu mesmo depois, no meu turno, reinar

e não ter de voltar entre inimizade e morte

e não fazer nem sofrer um mal, como acontece.

Ele aprovou e jurou perante os deuses,

e nada cumpriu do que prometeu, mas retém

ele mesmo o poder e a minha parte do palácio.

Agora estou pronto, se receber minha parte,

a retirar o exército deste terra

e viver em minha casa recebendo minha parte,

e depois, de novo, deixá-la pelo mesmo tempo,

e não destruir a pátria nem aplicar contra

os muros escadas fixas para escalada,

o que, se a justiça não for cumprida, tentarei

fazer. Chamo os deuses por testemunhas -

farei tudo com justiça, pois sem justiça

fui privado da pátria impiíssimamente.

\footnotetext{
${ }^{195}$ De acordo com Mastronarde (1994, p.281), Tăvסıx’ pode estar sendo utilizado no nominativo com o ठєĩ pessoal.

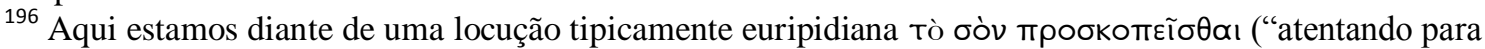

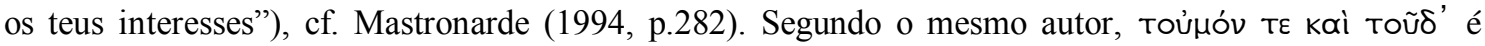

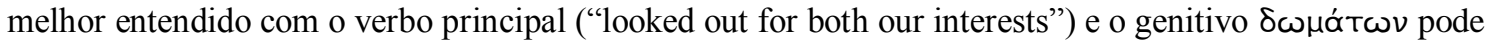

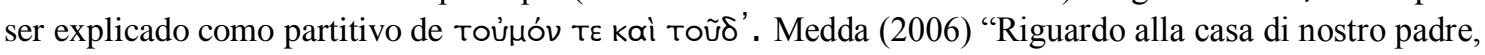
io mi sono preoccupato del mio e del suo interesse".
} 
Assim, claro e simples, mãe, sem rodeios,

reúno ${ }^{197}$ meus argumentos, tanto aos sábios

como aos simples, justos, como me parece.

Coro:

Para mim, embora não tenha sido criada

em terra grega, pareces falar com inteligência.

Etéocles:

Se a todos uma mesma coisa fosse bela e sábia,

não haveria contenda de duplo discurso.

Nada é igual ou semelhante para os homens,

a não ser em palavras: a realidade não é assim.

Assim, mãe, falarei nada escondendo:

eu iria até o horizonte dos astros do éter,

e abaixo da terra, se fosse capaz de fazer isso,

de modo a participar do maior dos deuses, a Tirania.

Pois este bem, mãe, não desejo passar

a outro mais do que retê-lo comigo.

Falta hombridade a quem perde o muito

e fica com o pouco! Ademais, envergonha-me

vir ele armado para devastar esta terra

e conseguir o que deseja. Que Tebas seja

censurada se por medo da lança micênica

eu entregue o meu cetro para ele o possuir.

Ele não devia pelas armas a reconciliação,

mãe, buscar - o discurso resolve sem falhas

o que o ferro dos inimigos poderia fazer.

\footnotetext{
${ }^{197}$ A tradução "reúno meus argumentos" se justifica pelo caráter militar do verbo åđeooíoas. Segundo Mastronarde (1994, p.287): "talvez a metáfora militar "reunir" ("mustering") deva ser entendida aqui".
} 
Mas, se de outro modo ele quiser aqui morar,

assim seja. O cetro, porém, não cedo!

Se cabe a mim reinar, serei eu servo dele?

Pois que venha o fogo, que venha a gládio!

Atai os cavalos, enchei o terreno de carros,

porque não lhe concedo o meu poder supremo ${ }^{198}$.

Se é mister ser injusto, pelo poder supremo

isso é o mais belo a se fazer; ao resto, a piedade.

Coro:

Não se deve falar bem de ações não belas,

pois belo isso não é, mas sim odioso à justiça.

Jocasta:

Filho, nem tudo que está ligado à velhice,

Etéocles, é ruim, mas é a experiência que

sabe falar mais sabiamente que os jovens.

Por que desejar a pior da divindades,

a Ambição, filho? Tu, não ${ }^{199}$ ! Uma deusa injusta...

A muitos lares e a prósperas cidades ela

visitou e saiu com a perdição ${ }^{200}$ dos que a seguiram.

Por ela enlouqueces. Melhor é, filho,

honrar a Igualdade, que sempre amigos a

\footnotetext{
198 Aqui traduzimos por "poder supremo" o que no verso 506 traduzimos por "tirania". A causa disso é que naquele verso se trata de uma divindade que, como vimos, tem um caráter negativo, enquanto que aqui se tem um substantivo comum. Em ambos os casos Craik (1988) traduziu por "monarchy", mas não

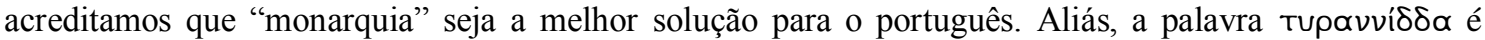
freqüente em Eurípides e não possui necessariamente um caráter negativo, como se vê, por exemplo, em

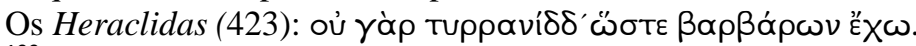

${ }^{199}$ Expressão coloquial, ver Collard (2005, p.367) e nota para o verso 735.

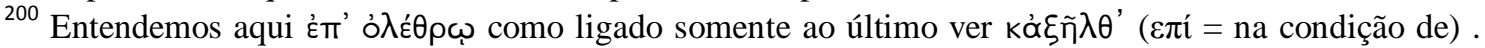
Outra maneira de se interpretar a oração é entendendo os dois verbos como uma par inseparável e $\varepsilon \pi i ́$ expressando finalidade, ver Mastronarde (1994, p. 300). Assim entende Craik (1988, p.91) em sua tradução: "she has come and gone, to the doom of those following her")
} 
amigos, cidades a cidades, e aliados a

aliados une. A igualdade é justa ao homem,

mas contra o maior sempre está em guerra

o menor e começam os dias de inimizade.

As medidas e os pesos para os homens

a Igualdade dividiu e delimitou os números;

a escura pálpebra da noite e a luz do sol

caminham lado a lado no ciclo de um ano,

e nenhuma delas perde e sente inveja.

O sol e a noite servem os mortais,

mas tu não suportas, rei sendo, igualmente

fazer a partilha com ele? Onde está a justiça?

Por que a Tirania ${ }^{201}$, uma injustiça feliz,

honras em excesso e a julgas de alto valor?

Honra para ser visto por todos? É vão.

Ou grande inquietude com grande posse

desejas? Que é o “mais”? É só um nome.

Não importa ${ }^{202}$ : ao sensato, o suficiente basta.

os mortais não possuem riqueza própria,

só tomamos conta daquilo que é dos deuses,

e quando lhes agrada, retiram-nas de novo.

\{A felicidade não é segura, mas efêmera ${ }^{203}$.

Vamos, se te pergunto com duas opções,

tiranizar a cidade ou salvá-la preferes,

dirás tiranizar? Mas se Polinices te vence

\footnotetext{
${ }^{201}$ Ver nota ao verso 506.

${ }^{202}$ Não há nenhuma palavra grega no original equivalente ao nosso "não importa" a não ser a aparição da partícula $\gamma \varepsilon$ duas vezes num mesmo verso. Como explica Mastronarde (1994, p.310), "a aparição de $\gamma \varepsilon$

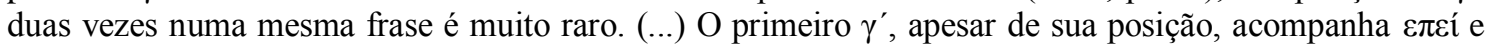
marca toda a frase como uma asserção ameaçadora ("não importa o que você pensa ou o que mais você poderia dizer')". Evidentemente, por se tratar de uma tradução em verso, tivemos de reduzir bastante o sentido desse $\gamma^{\prime}$. Craik (1988, p.93) traduz esse nuance das partículas com um "at any rate".

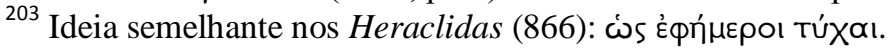


e a lança argiva captura a dos cadmeus,

verás dominada esta cidade tebana,

verás muitas de suas virgens cativas,

à força corrompidas ${ }^{204}$ pelos homens inimigos.

Custosa será esta riqueza que tu buscas

a Tebas; e mesmo assim és ambicioso.

Eis o que tenho para te falar; a ti, Polinices, digo:

são tolos os favores que Adrasto te rendeu,

sem inteligência vieste para destruir a cidade.

Eia, se tomas esta terra - que isso nunca ocorra -

pelos deuses, como elevarás troféus a Zeus?

Como farás os sacrifícios iniciais ao tomar a pátria,

e que inscrição farás nos espólios no rio Ínaco?

“Após incendiar Tebas Polinices oferece estes

escudos aos deuses"? Nunca, filho, uma glória

tal a ti aconteça de possuir entre os gregos.

Mas se fores dominado e prevalecer a força

do outro, como voltarás a Argos deixando

milhares de mortos? Alguém dirá: "Vil arranjo,

Adrasto, fizestes, pelo casamento de uma só

morremos". A dois males tu te lanças, filho,

perder o já conquistado e sucumbir ao intentado.

Cessai a soberbia, cessai. A tolice de dois homens,

quando se encontra, produz o pior dos males.

${ }^{204}$ É raro o uso do verbo $\pi$ o $\theta \varepsilon \dot{\varepsilon} \omega$ contendo como objeto uma pessoa, como diz Mastronarde (1994, p.314), para o qual, nesse caso, ele dá a seguinte solução de tradução: "taken as captives <through the capture of their city". Craik (1988, p.93), porém, traduz como "forcibly taken" e, em nota, explica que "forcibly taken" é um eufemismo para estupro. Cremos que a nossa tradução "corrompidas" abarca um pouco desses dois sentidos. 
Coro:

Ó deuses, sede o livramento desses males

e concedei aos filhos de Édipo um acordo.

Etéocles $^{205}$ :

Mãe, não mais se discurse contendas, o tempo se consome

em vão agora até a batalha... Teus esforços de nada valeram,

pois não chegaremos a acordo diferente do que já foi dito,

ou seja, eu com meu cetro sempre serei o senhor desta terra!

Deixa-me livre das tuas longas admoestações.

E tu, põe-te fora destes muros ou serás morto.

Polinices:

Por quem? Quem é tão invulnerável para contra nós

o gládio mortal levantar e não ter destino igual?

Etéocles:

Perto, não longe ele anda: não vês minhas mãos?

Polinices:

Vejo, mas a riqueza é covarde e muito apegada à vida.

Etéocles:

Por isso vens com muitos contra o reles na batalha?

Polinices:

\footnotetext{
${ }^{205}$ Eurípides altera o metro do diálogo para o tetrâmetro trocaico, um ritmo revivido por Eurípides em suas últimas peças, ver Mastronarde (1994, p.319). Drew-Bear (1968, p.386) mostra que, entre as peças supérstites dos três principais tragediógrafos, as de Eurípides são as que mais contém esse metro. Segundo esse mesmo autor, Frínico teria usado largamente o tetrâmetro trocaico, e foi Ésquilo quem de fato estabeleceu o trímetro jâmbico. Para essa cena, ele diz que "está claro que o tetrâmetro foi utilizado apenas quando as emoções vieram à flor da pele após o longo discurso de Jocasta" (p.400).
} 
Um general prudente é melhor que um arrogante.

Etéocles:

Estás falante porque crês numa trégua que te salva.

Polinices:

E também tu. De novo exijo o cetro e minha parte da terra.

Etéocles:

Nisso não serei instado. Sou eu quem rege esta casa.

Polinices:

Etéocles:

Tendo uma parte maior que a devida?

Exato. Deixa esta terra!

Polinices:

Etéocles:

Ó altares dos deuses ancestrais...

Que tu vens destruir...

Polinices:

Etéocles:

Ouvi-me... Quem ouviria a ti que lutas contra a pátria? 605

Polinices: Etéocles:

E vós, templos dos deuses de alvos cavalos... Que te odeiam...

Polinices:

Etéocles:

Expulsam-nos da pátria...

E tu vens para me expulsar...

Polinices:

Etéocles:

Injustamente, ó deuses... Invoque os deuses em Micenas ${ }^{206}$, não aqui!

${ }^{206}$ Também nos Heraclidas, Micenas é identificada com Argos. 
Polinices:

Tornaste-te ímpio...

Polinices:

...ao me expulsar sem minha parte.

Polinices:

Ó pai, ouves o que sofro?

Polinices:

E tu, mãe?

Polinices:

Ó pólis!
Etéocles:

Mas não, como tu, inimigo da pátria.

Etéocles:

E ainda hei de te matar. $\quad 610$

Etéocles:

E também ele ouve o que tu fazes.

Etéocles:

Está vetado a ti chamar pela mãe.

Etéocles:

Vai para Argos invocar a água do Lerne.

Polinices:

Etéocles:

Irei, não te inquietes. A ti agradeço, mãe.

Saia desta terra!

Polinices:

Etéocles:

Sairemos, mas permita-me ver meu pai._Isso nunca te ocorreria. 615

Polinices:

Etéocles:

Então minhas pequenas irmãs.

Jamais as verá de novo.

Polinices:

Etéocles:

Ó irmãs!

$\mathrm{Tu}$, maior inimigo delas, por que as invocas?

Polinices:

Jocasta:

Saúda-me, então, mãe.

Que satisfação sinto agora, filho... 
Polinices:

Não mais sou teu filho.

Polinices:

Porque este nos ultraja.

Polinices:

Onde estarás diante das torres?

Polinices:

Anteposto a ti, quero te matar.

Jocasta:

Ai de mim! Que estais fazendo, filhos?
Jocasta:

Para muito sofrer fui criada.

Etéocles:

Porque fui ultrajado.

620

Etéocles:

Por que me indagas isso?

Etéocles:

É esse também meu desejo.

Polinices:

Por si só se revelará.

Jocasta:

Etéocles:

Não fugireis da Erínia paterna ${ }^{207}$ ? Que toda esta casa se estiole.

Polinices:

Em breve meu gládio estará ocupado e manchado de sangue.

Os deuses e esta terra que me nutriu testemunham

que desonrado, indignamente, fui expulso daqui,

tal qual um escravo, não como um filho deste mesmo Édipo.

Se algo te ocorre, pólis, não minha, mas dele é a culpa

não foi de bom grado que vim, de mau grado fui expulso.

${ }^{207}$ Como tinha dito Polinices (474) explicando o motivo do seu auto-exílio. 
Saúdo a ti, Febo Senhor Aguieu, e a ti, palácio;

meus companheiros e as estátuas sacrificiais dos deuses.

Não sei se de novo me será dado vos saudar...

Esperanças não adormecidas me convencem:

Pelos deuses, mato-o e reino estas plagas tebanas.

Etéocles:

Saia desta terra! Realmente meu pai te nomeou

Polinices com uma pré-ciência divina, epônimo de lutas!

\section{$1^{\circ}$ ESTÁSIMO}

str.

Cadmo veio a esta terra,

o Tírio ${ }^{208}$, e, onde o tetrápode

novilho espontaneamente ${ }^{209}$

se deitou ${ }^{210}$, cumpriu-se

o oráculo: neste ponto habitar,

dizia a profecia, o campo

de trigo com casas ele devia ${ }^{211}$;

${ }^{208}$ A questão sobre a origem de Cadmo é controversa. Eurípides o aponta como fenício desde o prólogo (6), e agora o esmiúça a descrição mostrando-o originário de Tiro. Há fontes que concordam e discordam com essa informação. Heródoto, por exemplo, também menciona sua origem tíria $(2.49 .3 ; 4.147 .4)$ assim como assinala a origem tíria de Europa (4.45.4) - mas é o próprio Eurípides um dos que discorda de si mesmo, pois em As Bacantes (170-2) Cadmo é de Sídon. Fontenrose (1974, p.307) admite as duas possibilidades, Edwards (1979, p.46), porém, explica que nessa época Tiro e Sídon eram indistintamente sinônimos da Fenícia.

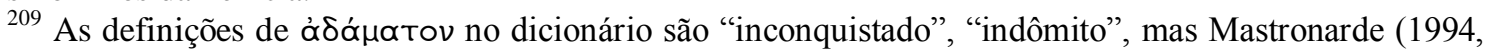
p.335) interpreta como "spontaneous, unforced, of her own free will" e explica: "os rituais geralmente exigem um animal puro e livre, mas neste contexto a não intervenção de agentes humanos no caminho escolhido pelo animal e em sua decisão de descansar é a mais significante exigência ritualística, e isso é

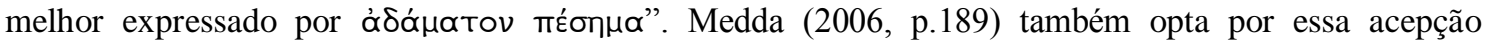
("spontaneamente si stese a terra"), assim como Amiech (2004, p.163): "sans y avoir été contrainte".

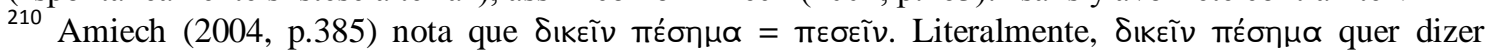
"lançar uma queda". $\pi \varepsilon ́ \sigma \eta \mu \alpha$ sozinha pode ter vários sentidos, mas nesse sintagma Mastronarde (1994, p.335) a entende como "threw herself down".

${ }^{211}$ O texto grego de 642-4 é problemático. Mastronarde (1994, p.335-6) cita algumas possiblidades variadas de tradução, pelo fato de $\delta$ ó $\omega \omega \nu$ poder estar corrompido. Ele escreve, por exemplo, "settle the 
aí o belo fluir de águas

e a umidade do Dirce

regam a terra, verdejante

e radicosa terra.

A Brômio aí gerou sua

mãe, esposada de Zeus,

a quem a hera, rodeando-o

ainda criança em coroa $^{212}$,

com verdejantes brotos

envolve-o em sombras e o abençoa:

ele é honrado em báquica dança pelas

moças tebanas e pelas

655bis

mulheres de evoés.

ant.

Ali estava o mortífero dragão

de $\operatorname{Ares}^{213}$, seu arisco guardião,

que as correntes d'água e as margens

verdejantes vigiava

660

com olhar circunspecto;

a ele matou Cadmo com uma pedra

vindo para a purificação ritual,

a cabeça mortífera atingindo

com o arremesso de seu braço mata-monstro.

665

Da deusa sem mãe,

fertile plains, filling them with homes", ou "the fertile plains, site of < future Theban $>$ homes". Craik (1988) traduz por "to settle lands, wheat producing, for his home", e Medda (2006) "ch'egli colonizzasse la fertile pianura, riempiendola di case".

${ }^{212}$ Para тєрібтєфทे' adotamos o sentido ativo defendido por Mastronarde (1994, p.338), "encircling as a wreath", e seguido por Medda (2006, p.189), "l'edera attorta, che forma corona".

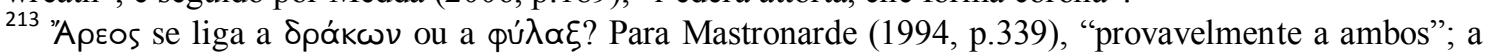
tradução de Medda (2006) concorda com a de Mastronarde, mas a de Amiech (2004) o liga somente a

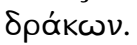


Palas, o conselho foi para $\quad 667$

na radicosa terra 669

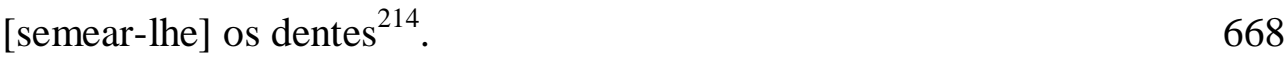

Daí a Terra produziu incrível $^{215} \quad 670$

visão de um exército armado

do extremo profundo do solo ${ }^{216}$ :

férrea-alma morte o reata à terra-mãe.

$\begin{array}{ll}\text { De sangue molhou-se a terra } & 674\end{array}$

$\begin{array}{ll}\text { que a eles mostrou } & 674 \mathrm{bis}\end{array}$

$\begin{array}{ll}\text { a brisa solar do céu. } & 675\end{array}$

ep.

E a ti, da primeva mãe 676

Io descendente,

Épafo, prole de Zeus, clamei, clamei $\quad 678-9$

$\begin{array}{ll}\text { a gritos bárbaros, } & \text { 679bis }\end{array}$

$\begin{array}{ll}\text { Ai! } & 680\end{array}$

$\begin{array}{ll}\text { Com preces bárbaras: } & \text { 680bis }\end{array}$

vem, vem a esta terra:

tua descendência a fundou,

e as deusas nomeadas em par,

Perséfone e a cara

Deusa Demeter, $\quad 685$

senhora de tudo, $\quad 686$

\footnotetext{
${ }^{214} \mathrm{O}$ problema que temos com a sintaxe dos versos 666-7-9-8 é: o conselho da deusa Atena diz respeito ao assassínio da serpente ou à semeadura de seus dentes? Mastronarde (1994, p.341) prefere a primeira opção, mas reconhece os problemas sintáticos e métricos desses versos. A tradução de Medda (2006) adota a segunda opção, enquanto a de Amiech (2004), a primeira.

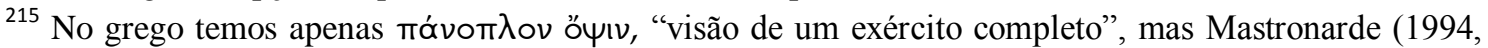
p.342) nota que se tem aí uma expressão elegante equivalente a "incrível visão". De fato, tanto Amiech (2004) como Medda (2006) traduziram por "espetáculo".

${ }^{216}$ Craik (1988, p. 99): "above the topmost surface of the land", mas Mastronarde (1994, p.342) nota o preciosismo da expressão e entende como "the earth's limiting shell".
} 
Terra $^{217}$ nutriz de tudo,

686bis

tomaram posse. Acompanha as deusas

porta-fogo, protege esta terra.

Tudo é favorável aos deuses.

689

\section{$2^{\circ}$ EPISÓDIO}

Etéocles:

Anda, traz-me aqui o filho de Meneceu,

690

Creonte, irmão de minha mãe Jocasta,

e diz-lhe isto: sobre minhas decisões,

privadas e públicas, desejo consultá-lo

antes de as lanças pormos em ordem de guerra.

Mas poupe-se dor em teus pés, ei-lo aqui..

Vejo-o se aproximando de meu palácio.

Creonte:

Muito andei por desejar te ver, senhor

Etéocles, e ao redor dos portões dos cadmeus

e das guaritas andei procurando por sua pessoa.

Etéocles:

Também eu desejava te ver, Creonte,

Pois achei muito insuficiente a reconciliação

${ }^{217}$ Sobre sincretismo de Demeter e Terra, ver capítulo II desta dissertação. 
Quando me pus em diálogo com Polinices.

\section{Creonte:}

Ouvi de sua arrogância para com Tebas ${ }^{218}$,

persuadido por sua aliança com Adrasto e seu exército.

É preciso, porém, confiar tudo isso aos deuses.

Algo mais urgente, isso é que venho relatar.

\section{Etéocles:}

O que é ${ }^{219}$ ? Não entendo teu pensamento.

\section{Creonte:}

Um prisioneiro dos argivos aqui veio.

\section{Etéocles:}

De lá? O que ele diz de novo? Fala ${ }^{220}$ !

\section{Creonte:}

O exército argivo está para sitiar, pelas torres,

a cidade dos Cadmeus com suas armas ${ }^{221}$.

\section{Etéocles:}

Que saia então da cidade o exército dos Cadmeus.

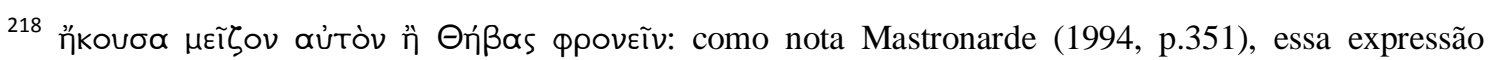
apresenta dificuldades para ser traduzida. Entre as possibilidades elencadas por ele, a que ele diz ser a melhor é "has overproud thoughts in regard to Thebes", que foi a adotada aqui. Medda (2006, p.197) traduziu por "ho sentito che egli mostra disprezzo per Tebe".

${ }^{219}$ Toíos precedido por artigo caracteriza uma expressão coloquial que reforça o contato entre os falantes, ver Collard (2005, p.368).

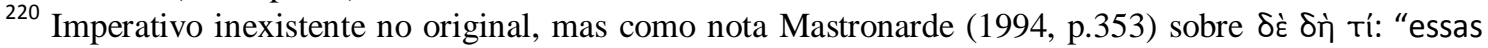
partículas e a postergação de tí enfatizam o verbo $\lambda \varepsilon ́ \gamma \varepsilon ı$, provavelmente marcando impaciência". Assim, usamos o imperativo para refletir essa impaciência.

${ }^{221}$ Craik (1988, p.207) e Mastronarde (1994, p.353) notam o estranhamento que causam esses dois versos na esticomitia de Creonte e Etéocles. Craik sugere a necessidade de se deletar o verso 710, mas Mastronarde ressalta que o caso para excisão é inconclusivo.
} 
Creonte:

Para onde? Por ser jovem, não vês o que precisa ser visto?

Etéocles:

Fora das trincheiras, para que lutemos presto.

Creonte:

Nossa força é pequena, a deles, enorme.

Etéocles:

Intimoratos eles são... nas palavras!

Creonte:

Argos tem imponência perante os gregos ${ }^{222}$.

Etéocles:

Coragem! Sem detença cobrirei o campo com morte.

Creonte:

Gostaria que assim fosse, mas grande penar vejo nisso.

Etéocles:

Não reterei meu exército dentro dos muros.

Creonte:

Em tudo a vitória depende de boas decisões.

\footnotetext{
${ }^{222}$ Medda (2006, p.196) diz que o elogio aqui feito a Argos possui um caráter também extra-dramático, pois, quando da encenação da peça, Argos e Atenas nutriam boa amizade. Mastronarde (1994, p.355), por sua vez, nota que a forma em que vem escrita o nome da cidade, tăpros, acrescenta dignidade a coisa representada por causa do artigo.
} 
Etéocles:

Preferes que eu me oriente por outros caminhos?

Creonte:

Por todos, antes de te arriscares de uma só vez.

Etéocles:

E se à noite os atacarmos de emboscada?

Creonte:

Sim, desde que voltes a salvo aqui, se derrotado.

Etéocles:

A noite é imparcial, mas favorece quem ousa.

Creonte:

A escuridão das desoras é terrível para se falhar.

Etéocles:

E se os atacar enquanto estiverem se alimentando?

Creonte:

Haveria grande alvoroço, mas vencer é o importante.

Etéocles:

Sim, e o caminho do Dirce para retirada é profundo.

Creonte: 
Tudo se mostra pior do que o bem se acautelar.

Etéocles:

E se cavalgássemos contra o exército dos $\operatorname{argivos}^{223}$ ?

Creonte:

Lá também o exército está rodeado de carruagens.

Etéocles:

Que farei então? Entrego a cidade aos inimigos?

Creonte:

É claro que não ${ }^{224}$ ! Mas decide-te, pois és sábio.

Etéocles:

Então qual outro plano se faria mais sábio ${ }^{225}$ ?

Creonte:

Dizem que sete de seus homens, conforme ouvi...

Etéocles:

Que foram ordenados a fazer? A força deles é pequena.

\section{Creonte:}

${ }^{223}$ Craik (1988, p.208) e Medda (2006, p.198) notam como essas três propostas de batalha feitas por Etéocles são mais apropriadas ao século quinto do que ao tempo heróico de Édipo. Craik vai além e relaciona essas propostas com os eventos bélicos que envolveram Atenas e Esparta nos anos 411 e 410 , assim como mostra a aproximação de Eurípides, com esse diálogo, dos debates sofistas sobre guerra.

${ }^{224}$ Exemplo de expressão coloquial de brevidade em que ocorre elipse de um imperativo com $\mu \eta ́$, ver Collard (2005, p.367). O mesmo ocorre no verso 532.

${ }^{225}$ Craik (1988, p.103) traduz por "what prudence is more sensible than forethought?" por entender прóvoia como "forethought", aliás o primeiro significado dado nos dicionários (cf. LSJ). Contudo, Mastronarde (1994, p.357) argumenta que aqui mpóvoı possui o sentido de "plan", plano, que é como também traduz Medda (2006), "Ma quale piano potrebbe essere più accorto?", e Amiech (2006), "plan”. 
Comandar seus batalhões contra as sete portas $^{226}$.

Etéocles:

Que faremos então? Não vou continuar nesse impasse.

Creonte:

Sete homens para as portas escolhe também tu contra eles.

Etéocles:

Para liderar batalhões ou para batalha singular?

Creonte:

Batalhões, preferindo sempre os mais audazes.

Etéocles:

Compreendo: para evitar as escaladas nas muralhas.

Creonte:

Escolhe também co-comandantes ${ }^{227}$ : um só homem não vê tudo.

Etéocles:

Com preferência pela coragem ou pelo espírito deliberativo?

\section{Creonte:}

Por ambas, pois uma sem a outra equivale a nada ${ }^{228}$.

\footnotetext{
${ }^{226}$ Conforme notam Mastronarde (1994, p.357) e Medda (2006, p.200), esse verso é problemático devido

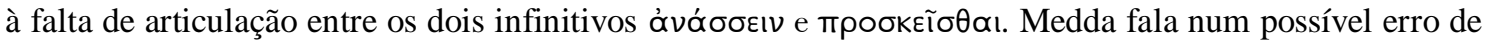
copista, que teria copiado o início do verso 742 no 739.

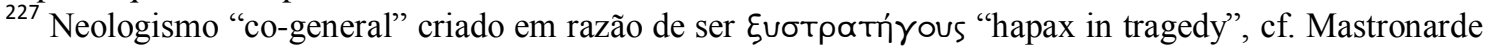
(1994, p.358). O estudioso também rejeita a interpretação de que aqui Creonte estaria aconselhando a designação de sete ajudantes para os sete comandantes das portas tebanas; ele entende como "generals along with yourself'.
} 


\section{Etéocles:}

Assim seja. Irei à entrada ${ }^{229}$ das sete torres

e organizarei os líderes pelas portas, como dizes,

contrapondo os inimigos de igual para igual.

Nomear $^{230}$ cada um deles é muita perda de tempo ${ }^{231}$

quando os inimigos já estão a postos nas muralhas.

Parto agora, para não inerciar minhas mãos.

Que eu encontre meu irmão face a face

e, ali na batalha, o mate ${ }^{232}$ com minha lança.

\{Matar quem a minha pátria veio destruir ${ }^{233}$ \}

Do casamento de minha irmã Antígone com teu filho

Hemom, se eu falhar em cumprir meu destino ${ }^{234}$,

cabe a ti cuidar. Sobre o nosso prévio acordo,

reafirmo-o agora, à hora de minha saída.

De minha mãe és irmão: que há ainda a ser dito?

Trata bem dela, tanto por mim quanto por ti.

Meu pai incorreu em erronia contra si mesmo

cegando-se os olhos: não me admira nada:

se for o caso, mata-nos com suas maldições.

Mas algo ainda nos escapa: se algum oráculo

\footnotetext{
${ }^{228}$ Mastronarde (1994, p,359): "for either one, If separated <from the other>, is worthless"; ele ainda explica que $\grave{\alpha} \pi \mathrm{o} \lambda \varepsilon \imath \varphi \theta \dot{\varepsilon} v$ é utilizado em absoluto e $\theta$ á $\tau \varepsilon \rho o v$ tem um sentido indefinido.

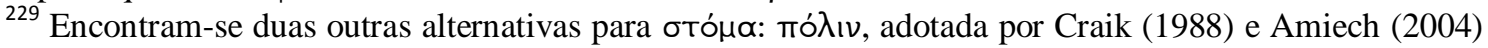

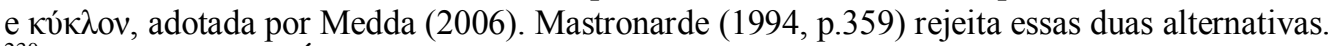

${ }^{230}$ Alusão à peça de Ésquilo Sete contra Tebas. Se essa alusão Eurípides faz com espírito de zombaria ou de reconhecimento, ver comentário de Mastronarde (1994, p.360) que enumera a disputa de duas escolas em torno desse assunto.

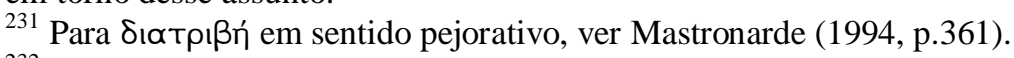

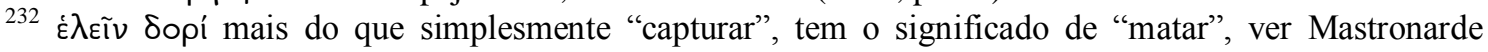
(1994, p.363). Medda (2006) também traduz por "matar": "ucciderlo con la mia lancia".

${ }^{233}$ Verso idêntico ao 1376. Mastronarde (1994, p.363) questiona a genuinidade desses dois versos.

${ }^{234}$ Algumas traduções interpretam essa oração como se uma eventual falha de Etéocles fosse culpa da sorte: "Amiech (2006, p.169): "si en quoi que ce soit la fortune venait à m'abandonner", Medda (2006): "se la sorte mi sarà avversa". Mastronarde (1994) esboça uma tradução mais literal ("If I at all fail of attaining the success I hope for") que é a qual se deu preferência aqui.
} 
o ornitomante Tirésias puder nos revelar,

indaguemo-lo. Quanto a mim, teu filho

Meneceu, que carrega o nome de teu pai,

enviarei para me trazer aqui Tirésias, Creonte.

Com prazer ele virá conversar contigo,

mas eu tenho censurado a arte divinatória,

mesmo perto dele, e ele me tem repulsa.

À cidade e a ti solicito isto, Creonte:

Se meu partido prevalecer, o corpo de Polinices

jamais deve ser enterrado nesta terra tebana,

e que morra quem o fizer, mesmo que seja parente.

Isso eu falo a ti. Para os meus servos, digo:

trazei minha armadura e minhas armas,

para que ao combate de lança assinalado

partamos já com a Justiça porta-vitória.

A Precaução, dos deuses a mais préstima,

supliquemos que salve nossa cidade.

\section{$2^{\circ}$ ESTÁSIMO}

str.

Ó Ares pungente, por que te arrebatas

com morte e sangue, destoando-te das festas de Brômio?

Teu sopro de pífaros destoa das formosas danças

de jovens ${ }^{235}$ coroadas que revolvem os cabelos,

tu não cantas a musa de grácil dança,

\footnotetext{
${ }^{235}$ A interpretação que Mastronarde (1994, p.378) dá a esse verso é "amidst garlands worn by beautiful youth in their fair dances", que, para ele, é uma expressão rebuscada para "joining the lovely dances of

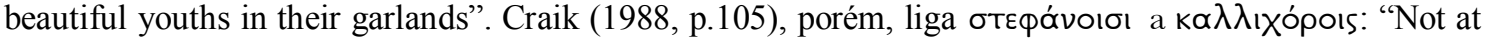
the lovely garlanded dance of young girls".
} 
mas a ferro e fogo insuflas em sangue o exército argivo

$\begin{array}{ll}\text { contra a estirpe }^{236} \text { tebana } & 790\end{array}$

e conduzes a dança numa bagunça sem nenhuma flauta.

790bis

Não é pela loucura tírsica, entre muitos vestidos em pele de cervo,

que volteias com o cavalo entre $\operatorname{carros}^{237}$

pelo correr do rio Ismeno

mas avanças com cavalos, inspirando contra

os argivos a raça dos semeados,

grupo báquico armado, portador de escudo,

e vestindo com bronze

O inimigo na muralha de pedra.

797bis

Terrível divindade é Éris, que essas

penas planejou aos reis da terra,

aos muito sofredores labdácidas.

800

ant.

Ó bosque de folhas sagradas, o mais

frequentado por bestas, olho de neve de Ártemis ${ }^{238}$,

Citerão: que nunca o assinalado para a morte, Édipo,

rebento de Jocasta, tu tivesses alimentado,

inda bebê expulso de casa, cravejado em ouro!

Nem que a alada, inúbil, Esfinge, monstro dos montes,

tivesse vindo molestar esta terra

com seus desentoados cantos,

\footnotetext{
${ }^{236}$ Há duas linhas principais de tradução para aímaтı అŕßas: 1) a de Mastronarde (1994, p.380), "the race/offspring of Thebes" e 2)a de Craik (1988, p.107), "with bloodlust against Thebes" (embora, em seu comentário, ela também admita a primeira possibilidade).

${ }^{237}$ A dificuldade de tradução dos versos 791-2 vem do fato de estarem esses versos corrompidos, ver longo comentário de Mastronarde (1994, p.380-2). Craik (1988, p.212) afirma que "é impossível extrair um sentido do texto grego transmitido".

${ }^{238}$ A tradução de Kovacs (2002, p.299), "Artemis's delight”, contraria a explicação dada por Mastronarde

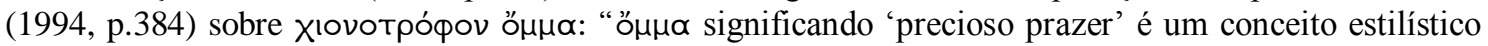

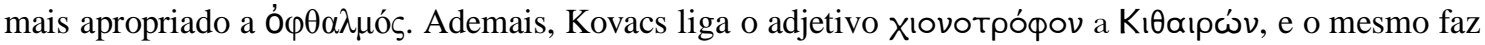
Amiech (2004, p.173). Medda (2006, p.207), por sua vez, segue a interpretação de Mastronarde ("occhio nevoso di Artemide, Citerone") e também nós.
} 
quando com quatro patas afiadas se aproximou

das muralhas, lançando para a luz inacessível do Éter

a raça cadmeia: por Hades do subtérreo

ela foi enviada aos cadmeus ${ }^{239}$. Mas é outra desditosa

Éris, aquela entre os filhos,

que cresce palácio e na cidade de Édipo ${ }^{240}$.

Do que não é belo jamais vem o belo,

nem dos ilícitos filhos,

brotos da mãe, miasmas do pai:

ela se deitou no leito de um consanguíneo.

$<$

$817 \mathrm{bis}$

ep.

Criaste, ó Gaia, criaste outrora,

como então aprendi em casa por bárbaro rumor,

a geração nata dos dentes da serpente de crista carmesim

devorante de feras - belíssima desonra ${ }^{241}$ para Tebas.

Para as núpcias de Harmonia,

os uranidas vieram então; ao som da harpa

e das liras de Anfião ${ }^{242}$ ergueram-se a muralha

tebana e as torres entre gêmeos rios,

onde o Dirce rega o verdejante

plano em frente ao Ismeno,

e Io ${ }^{243}$ cornuda, mãe primeira,

\footnotetext{
${ }^{239}$ Segundo Pseudo-Apolodoro (Biblioteca, 3.5.8), a Esfinge teria sido enviada a Tebas por Hera.

${ }^{240}$ Os versos 811-13 apresenta possibilidades de tradução diversas, conforme vemos pela tradução de

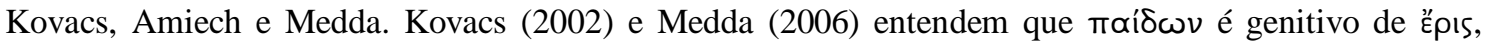

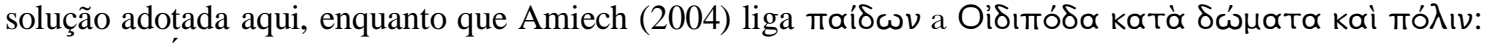
"la funeste Éris/ prospere/ dans le palais et la cite des fils d'Oedipe".

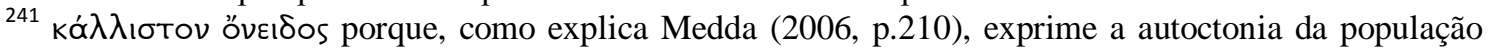
tebana (valor positivo) e a bestialidade de sua origem (valor negativo).

${ }^{242}$ Como visto em nota anterior, para Homero (Od. XI, 262-3) Zeto e Anfião foram os fundadores de Tebas. Nesta peça, Anfião já tinha sido citado como o construtor das muralhas de Tebas (115), e sobre Zeto foi feita uma referência ao seu túmulo(145).
} 
gerou os reis dos cadmeus.

Recebendo bênçãos atrás de

bençãos

esta cidade se elevou às alturas

das coroas de Ares $^{244}$.

\section{$3^{\circ}$ EPISÓDIO}

Tirésias:

À frente guia-me, filha ${ }^{245}$; tu és como a visão 834

para o meu cego passo, como o astro ao navegante.

Aqui, conduze meu andar por um caminho plano,

segue à frente para não cairmos. Débil é teu pai.

Guardem as tuas virgíneas mãos estes oráculos ${ }^{246}$ :

obtive-os observando os presságios dos pássaros

no hierático sólio ${ }^{247}$ de onde sempre profetizo.

Jovem Meneceu, filho de Creonte, dize-me

o quanto falta, por este caminho citadino,

até alcançarmos teu pai. Meus joelhos doem.

Mal posso continuar com esses passos rápidos.

\section{Creonte:}

\footnotetext{
${ }^{243}$ Como visto no párodo (247), Io é considerada aquela que "gerou os reis cadmeus" porque foi bisavó de Agenor, pai de Cadmo.

${ }^{244}$ Sobre desfecho ambíguo deste estásimo (830-3), e discussão sobre sua legitimidade, ver Parry (1967).

${ }^{245}$ Aparentemente, o nome da filha de Tirésias era Manto. Amiech (2006, p.434) cita um escólio

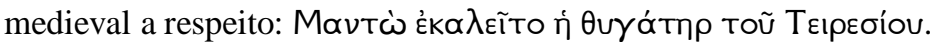

${ }^{246}$ Mastronarde (1994, p.394) nota que o $\mu$ óviıs fazia uma espécie de anotação de suas previsões e que o $\mathrm{\lambda}$ ก̃

${ }^{247}$ Pausânias relata ter visto o oỉ
} 
Coragem, Tirésias, pois próximo a amigos

já ancoraste os pés. Tu, meu filho, segura-o.

Como toda carruagem, o pé do ancião anseia

por uma mão alheia na expectativa de alívio ${ }^{248}$.

Tirésias:

Pois bem, aqui estamos. Por que a urgência, Creonte?

Creonte:

Como esquecer ${ }^{249}$ ? Mas recupera tuas forças,

retoma o fôlego exaurido no íngreme caminho.

Tirésias:

Fatigado eu chego, vindo da terra dos Erectidas

antes de os argivos terem sitiado a cidade ${ }^{250}$.

Lá também houve uma guerra - contra Eumolpo -,

e eu fiz dos Cecropidas renomados vencedores.

Esta coroa dourada trago comigo, como vês,

recebida como primícia dos espólios da guerra.

\section{Creonte:}

O melhor dos presságios considero tua coroa.

Em plena procela, tu sabes, nos encontramos

contra a lança dos dânaos e Tebas se turba.

${ }^{248}$ Os versos 847-8 também são bastante problemáticos. Amiech (2006, p.437) relata que Wecklein elaborou um repertório de 29 alternativas diferente de como interpretá-los e que Diggle seguiu a correção

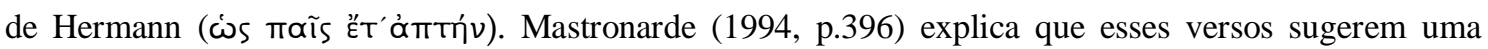
comparação com a necessidade que uma mulher tem de uma mão de fora para descer da carruagem.

249 oủ $\pi \omega \lambda \varepsilon \lambda \ln ^{\prime} \sigma \mu \varepsilon \theta^{\prime}$ tem suscitado controvérsias entre estudiosos. Enquanto Mastronarde (1994, p.397) vê em oü $\pi \omega$ "um tom coloquial de amistosa ironia", Amiech (2006, p.437) afirma enfaticamente não ver nenhuma ironia aí: para ela, trata-se antes de uma expressão de deferência de Creonte para com Tirésias.

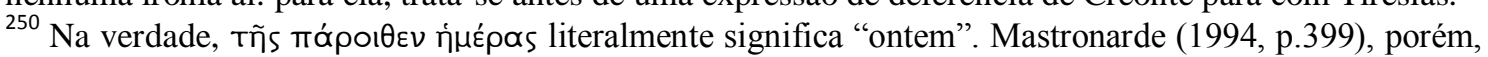
nota que Eurípides "preocupa-se com o menor detalhe de plausibilidade ao invés de deixar implícito que Tirésias teria chegado a Tebas sob salvo-conduto do exército argivo". 
Nosso rei Etéocles, vestido em armas, partiu agora para enfrentar as forças micênicas.

Comandado por ele devo indagar-te

sobre o melhor modo de salvarmos a cidade.

Tirésias:

Em prol de Etéocles prefiro fechar minha boca

e refrear o oráculo; para ti, porém, se queres saber,

Falo: enturba-se esta terra há muito, Creonte,

desde quando Laio contra os deuses teve um filho

e gerou infeliz Édipo como esposo para mãe.

A sangrenta ruína de suas pupilas foi um plano

dos deuses, uma lição para toda a Hélade.

Quiseram então os filhos de Édipo ocultar

esses fatos, como se pudessem fugir aos deuses,

e erraram como tolos. Nem honra nem expediente

concederam ao pai, e ao homem desafortunado

enfureceram. Expele então Édipo contra eles hediondas

maldições, injuriado e desonrado como estava.

$\mathrm{Eu}$, nada fazendo e nenhuma palavra proferindo, tornei-me um inimigo dos filhos de Édipo: por quê?

A morte se lhes aproxima, Creonte, por mão-irmã.

Cadáveres sobre cadáveres tombarão em série,

as hastas argivas e cadmeias roçando-se

causarão pungentes gemidos ao solo tebano.

E tu, infausta pólis, serás arrasada pela raiz

se as minhas prédicas ninguém atender.

Melhor seria que nenhum dos filhos de Édipo 
fosse cidadão ${ }^{251}$ ou senhor desta terra,

possessos que estão para derribar a cidade.

Assim, sendo o mal mais forte que o bem,

não há agora senão um meio de salvação.

Não é, contudo, seguro que eu me pronuncie,

e acre será a palavra para aquele a quem cabe

fornecer o remédio de salvação para a cidade.

Parto daqui, adeus! Um entre muitos, padecerei,

se necessário, o que há de vir. Que posso fazer?

Creonte:

Tirésias:

Alto lá, ancião!

Não me retenhas.

Creonte:

Tirésias:

Fica. Por que vais embora?

A tua sorte vai, não eu.

Creonte:

Mostra aos cidadãos e à cidade a salvação.

Tirésias:

É o que desejas agora, mas logo não desejarás mais.

Creonte:

Como não quereria eu salvar a terra pátria?

Tirésias:

Sim? Desejas ouvir assim com tanto ânimo?

${ }^{251}$ Ou seja, deviam estar exilados. 
Creonte:

A que outra coisa deveria eu ter mais anseio?

Tirésias:

Então tu hás de ouvir os meus oráculos.

Primeiro, contudo, quero saber, sem rodeios, isto:

onde está Meneceu, que até aqui me guiou?

905

Creonte:

Ele não se afastou muito, está perto de ti.

Tirésias:

Que ele parta então e fique longe dos meus oráculos.

Creonte:

Ele como filho nascido de mim sabe silenciar o que deve.

Tirésias:

Queres então que eu fale em sua presença?

Creonte:

Ele se alegraria ao ouvir sobre a nossa salvação.

Tirésias:

Ouve então a que caminho leva o meu oráculo

\{o que devemos fazer para salvarmos a cidade

É mister que tu, pela pátria, mates Meneceu, 
o teu filho; isso foi tu quem quis saber ${ }^{252}$.

\section{Creonte:}

Que dizes? Que significa este teu falar, velho?

Tirésias:

O que se revelou foi isso. Cabe a ti realizá-lo.

Creonte:

Ó, quantos males disseste em tão curto tempo!

Tirésias:

Para ti, mas para a pátria, algo grandioso e salvador.

\section{Creonte:}

Eu nada ouvi, nada escutei... Adeus, cidade!

Tirésias:

Este homem já não é o mesmo. Recua a cabeça...

Creonte:

Adeus, podes ir. Não preciso mais de tuas predições.

Tirésias:

A verdade se perde porque tu te desgraças?

Creonte:

Por teus joelhos e por teus veneráveis cabelos...

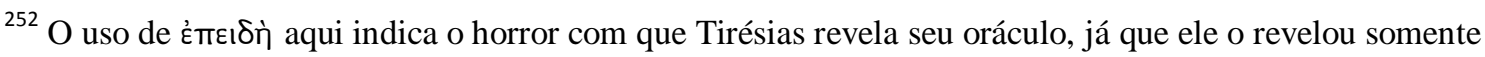
a custo da insistência de Creonte, cf. Mastronarde (1994, p.411). 
Tirésias:

Do chão me suplicas? Rogas por males incontornáveis.

Creonte:

Cala-te. Não digas a cidade mais nada sobre isso.

Tirésias:

Ordenas que eu pratique injustiças? Não posso me calar.

Creonte:

Que vais fazer comigo? Vais matar meu filho?

Tirésias:

Isso compete a outros, a mim cabe somente falar.

Creonte:

Mas de onde vem isso que desgraça a mim e a meu filho?

Tirésias:

É justo que tu me questiones e me contestes.

É preciso sacrificá-lo na gruta onde a terrígena

serpe, guardiã das águas do Dirce, nasceu,

como libação de sangue para a terra,

por causa da antiga ira de Ares contra Cadmo:

o deus agora vinga a morte da terrígena serpe.

Fazendo isso atraireis Ares como aliado vosso.

Se o solo recebe fruto por fruto, sangue por sangue

humano, ser-vos-á favorável a Terra que outrora 
para nós fez brotar a seara dos Semeados

de elmos dourados. Dessa estirpe é preciso morrer

um filho, aquele gerado da mandíbula da serpe.

$\mathrm{Tu}$, aqui, és quem nos resta da raça do Semeados,

puro pela parte da mãe como pela parte do pai,

e assim também teus filhos: o casamento de Hemom

aparta-o do sacrifício. Não é mais solteiro: embora

irrealizadas ainda as núpcias, já tem esposa.

Este novilho, porém, deixado livre ao redor da cidade ${ }^{253}$,

morrendo poderia salvar a terra de seus pais.

Assim, de acre sabor será o retorno de Adrasto e dos

argivos, negra ruína caindo sobre seus olhos,

e Tebas sairá gloriosa. Desses dois destinos, escolhe

tu um, isto $\mathrm{e}^{254}$, ou salvas o filho ou a cidade.

De nossa parte, isso é tudo. Vamos, meu filho,

leva-me para casa. Quem trabalha com adivinhação ${ }^{255}$,

trabalha em vão: se os sinais são de mau agouro,

odioso ele se torna a quem quer que profetize,

se, por compaixão, ele mente a quem o consulta

injusto se torna perante os deuses. Febo é o único

que deveria vaticinar, ele que não teme a ninguém.

\section{Coro:}

Creonte, por que calas a voz neste silêncio inercial?

\footnotetext{
${ }^{253}$ O sentido de ớveıuévos aqui, como notam Mastronarde (1994, p.419), Amiech (2004, p.456) e Medda (2006, p.225) pertence ao campo semântico religioso. Tanto Amiech e Medda traduzem pelo termo equivalente a "consagrado", mas Mastronarde nota que o melhor significado é "“left untilled' or 'allowed to roam free"”, já que está relacionado a $\pi \tilde{\omega} \lambda$ os, que, curiosamente, como mostra o mesmo autor, é comumente usado para se referir a meninas inuptas.

${ }^{254}$ Segundo Mastronarde (1994, p.420) este yò $\rho$, por ser aposicional, tem o sentido de "that is to say". Nem a tradução de Medda nem a de Amiech, contudo, trazem esse matiz da partícula.

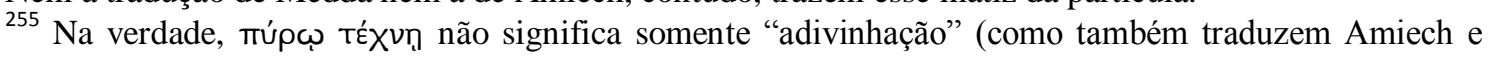
Medda), mas "arte da adivinhação pela inspeção das ofertas queimadas”, cf. Mastronarde (1994, p.420).
} 
Não menor que o teu é o meu espanto.

\section{Creonte:}

O que poderia ser dito? Meu pensamento é óbvio:

eu jamais chegaria a esse ponto de desgraça de ter que sacrificar meu filho em oferecimento à cidade.

Para toda a humanidade, viver é amar os filhos ${ }^{256}$, 965

e não há quem dê a própria prole para a morte.

Não venha me louvar quem vem matar meu filho!

Eu mesmo, já chegado a esta altura da vida,

pronto estou para morrer como resgate da pátria.

Mas eia, filho, antes que toda a cidade o saiba,

esquece tu esses levianos oráculos de adivinhos

e foge o mais rápido desta terra, salva-te ${ }^{257}$.

Ele anunciará isso a comandantes e generais

indo aos sete portões e aos seus sete estrategos.

Se agirmos primeiro, ainda haverá salvação para ti,

mas se tu demoras, estamos acabados - e morres.

\section{Meneceu:}

E para onde vou fugir? Que cidade me hospedará?

\section{Creonte:}

Para onde estiveres o mais longe possível dessa terra.

\section{Meneceu:}

${ }^{256}$ Ver verso 356.

${ }^{257}$ As traduções mais recentes da peça optaram por traduzir áma $\pi \lambda \alpha \chi \theta \varepsilon \dot{s}$ como sinônimo de $\phi \varepsilon \tilde{v} \gamma$ '. Assim, Kovack (2002) traduz simplesmente por "leave the country as fast as you can" e Amiech (2004) e Medda (2006), respectivamente, optam por duas orações imperativas: "Fuis au plus vite, quitte cette terre", "fuggi al più presto, lascia questa terra". Nossa tradução preferiu interpretar o particípio ám $\alpha \lambda \lambda \alpha \times \theta \varepsilon i s$ em seu sentido primeiro, ou seja, "livrar-se de, libertar-se de". 
Não convém a ti propor o plano, e a mim, executá-lo?

Creonte:

Passando por Delfos...

Creonte:

Até à terra Etólia.

Creonte:

Ao chão Tesproto.

Creonte:

Correto!

Creonte:

Um deus será teu guia.

Creonte:

Eu te envio ouro.

Creonte $^{258}$ :

Parte então.
Meneceu

Para onde devo ir, pai? 980

Meneceu:

E de lá para onde?

Meneceu:

Ao sagrado solo de Dodona?

Meneceu:

Que proteção encontrarei lá?

Meneceu:

E quais serão meus recursos?

Meneceu:

Muito bem, meu pai. 985

Meneceu:

Saiba que ${ }^{259}$ vou até tua irmã,

Jocasta, aquela de cujo seio primeiro me nutri,

privado e apartado de minha mãe, órfão.

Digo-lhe adeus e parto para salvar minha vida.

\footnotetext{
${ }^{258}$ Há controvérsia sobre de quem seria essa fala. Mastronarde (1994), Amiech (2004) e Medda (2006) a atribuem a Creonte (ver nota de cada um deles $a d l o c$ ), mas Kovacs (2002) a atribui a Meneceu. 259 "'́s, no início de um discurso: "saiba que...”, cf. Mastronarde (1994, p.426).
} 
Creonte:

Mas vai, parte! Que nada atrapalhe os teus $\operatorname{planos}^{260}$.

990

\section{Meneceu:}

Mulheres, consegui dissipar o medo de meu pai

encobrindo com palavras o que desejo fazer.

Ele me afasta daqui, privando a cidade de sua sorte,

e faz de mim um covarde. Perdoe-se isso a um

velho, mas não se admita perdão para mim se

eu me tornar traidor da cidade que me criou.

Saibam todos: irei sim salvar a cidade e

darei a minha vida morrendo por esta terra.

Seria indigno: os que estão livres dos oráculos

e a quem não sobreveio o jugo dos deuses

não hesitam em morrer junto de seus escudos,

lutando pela pátria em frente às torres;

mas eu, traindo meu pai, meu irmão e minha

própria cidade, hei de partir como um covarde

daqui e parecer um vilão onde quer que esteja?

1005

Não, por Zeus que habita os astros, por Ares mortífero

que fez outrora ascender da terra os Semeados

e os estabeleceu como senhores desta terra.

Devo partir. Subindo ao alto de nossas guaritas,

mato-me, e, fazendo escorrer meu sangue ${ }^{261}$ ao antro

1010

\footnotetext{
${ }^{260}$ Qual devemos entender ser o sujeito do verbo imperativo $\kappa \omega \lambda$ vé $\omega \omega$ ? De acordo com a tradução de Kovacs (2002, p.321), o sujeito é Jocasta: "let her not prevent your departure". Amiech (2004) e Medda (2006), respectivamente, entendem "Meneceu" como sujeito "Ne fais pas toi-même obstacle à ton plan", "non crearti ostacoli da solo".

${ }^{261}$ Nossa tradução "fazendo escorrer meu sangue" se deve à explicação de Mastronarde (1994, p.430) a respeito do uso da preposição $\mathfrak{\varepsilon} \xi$ nesse verso: "a preposição de distanciamento é utilizada num senso antecipatório, refletindo uma ação subsequente nomeada ou implícita no contexto: assim, aqui 'pondo-me no extremo da muralha, deixando meu sangue sacrificial escorrer daqui até a toca do dragão". Essa é também a escolha feita pela tradução de Medda (2006). Kovacs (2002, p.321) e Amiech (2004, p.185)
} 
negro da serpe, local prescrito pelo profeta,

salvo minha terra. Essas são minhas palavras.

Andemos. Minha dádiva à cidade é minha morte -

em nada vergonhosa. Dessa doença livro a terra.

Se cada um contribuísse com o bem que pode,

examinando-o ${ }^{262}$ e aplicando-o ao bem comum

1015

da pátria, menos males as cidades experimentariam

e no futuro haveriam de apenas prosperar.

1018

$3^{\circ}$ Estásimo

str.

Vieste, vieste,

1019

ó alada, da terra

1019bis

criatura e da ínfera Equidna ${ }^{263}$,

dos Cadmeus a rapinante,

ruína e gemido de muitos,

virgem híbrida ${ }^{264}$,

1023

mostro terrível

1023bis

de asas frenéticas e

garras omófagas $^{265}$.

traduzem de forma diferente. Esta subentende a ação de lançar-se de cima para baixo de Meneceu ("je m'immolerai en me précipitant dans le noir et profond repaire du serpent"), enquanto que aquele entende que a imolação apenas se dará acima da toca da serpente ("slit my own throat above the deep black precinct").

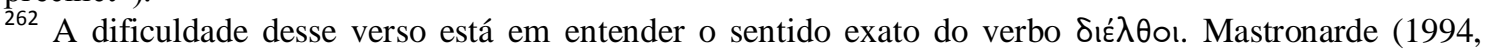
p.433) lista pelo menos quatro possibilidade e, dessa lista, prefere entendê-lo aqui por "go through, review, consider in detail". Kovacs (2002) o traduz por "examinar" ("examine it thoroughly"). Amiech

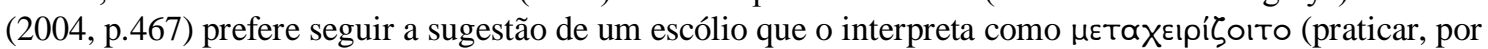
em prática), solução que também é adotada por Medda (2006).

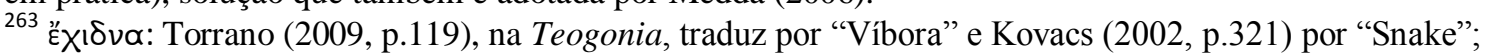
Amiech (2004, p.187) e Medda (2006, p.231), porém, preferem a versão transliterada de "Échidna". Ela é, na verdade, semininfa e semi-serpente, filha de Ceto, filha de Terra e Mar (Theog. 295-303).

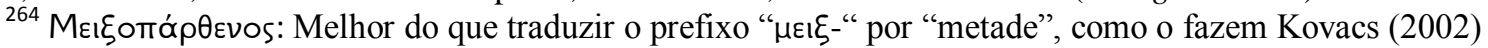
e Medda (2006), preferimos o sentido de "misturar", adotado também por Amiech (2004).

${ }^{265}$ Os dativos instrumentais dos versos 1024-5 podem acompanhar o éßas de 1019, mas também o

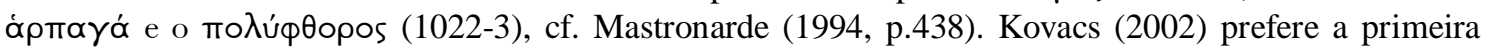
opção, tanto que repete, em sua tradução, o verbo "[you] came” de 1019. 
Ao redor do Dirce, outrora,

arrebataste os jovens

$\operatorname{com}^{266}$ teu canto sem lira,

e com Erínia destrutiva ${ }^{267}$,

trouxeste, trouxeste a pátria

1030

dores letais. Letal entre

os deuses quem isso realizou.

O chorar das mães,

o chorar das filhas

ressoavam ${ }^{268}$ nos lares.

Um grito de ai,

um canto de ai

um e outro exprimiam,

sucessivamente, pela cidade.

A trovões os gemidos

e os brados $^{269}$ se assemelhavam,

quando subtraía da cidade

a virgem alada algum dos homens.

1042

ant.

Em tempo veio,

pelo mando da Pítia,

1043bis

o sofrido Édipo

a esta terra tebana,

aliviada então, dolorida depois ${ }^{270}$.

${ }^{266}$ O óụí aqui tem o sentido de "por causa de" ou "com”, cf. Mastronarde (1994, p.439).

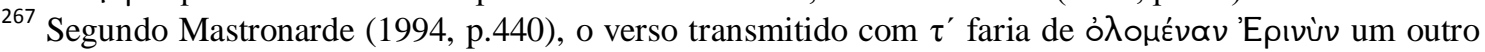
objeto de $\alpha \mu \phi i ́$ (1028). Kovacs substitui o $\tau$ ' por $\gamma^{\prime}$, logo traduz “cursed Erinys" como aposto de $\mu$ oũo $\alpha \nu$ (1028).

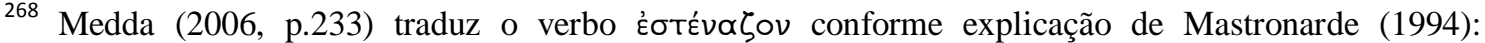
"sounded mournfully". Kovacs (2002) e Amiech (2004) não utilizam tal advérbio.

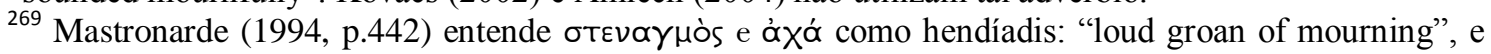
assim também traduz Medda (2006). Kovacs (2002) traduz como dois nomes coordenados: "the groans and lamentations". Amiech (2004) utiliza uma outra edição, onde ơxó se encontra no dativo, ligando-se, portanto, a ßpovтỡ. 
Núpcias, insalubres

núpcias, o sofrido,

vitorioso embora dos enigmas,

estabelece com a mãe,

e macula a cidade.

Ele põe seus filho, por atos de sangue ${ }^{271}$,

em cruenta batalha,

lançando-lhes maldições,

miserável! Admiramos, admiramos

o que se dirige à morte

pela pátria terra,

a Creonte deixando em choro,

mas para a terra de sete torres cerradas ${ }^{272}$

vitória concedendo.

pudéssemos ser mães assim,

pudéssemos ter tão bons filhos, querida

Palas, tu que o sangue da serpente

derramaste num lance de pedra,

a atenção de Cadmo

movendo para tal serviço.

Por causa disso veio sobre esta terra,

para rapina, um dos numes, Ate.

\footnotetext{
${ }^{270}$ Aqui, seguimos a explicação de Medda (2006, p.234) que entende o dativo Tót' ảouévoıs dependente de $\varepsilon_{\beta} \propto$ (1043). Esse dativo representaria, então, os cidadãos tebanos a quem Édipo salvara: "venne a loro che ne furono felici". Numa adaptação, traduzimos o dativo como se referindo a Tebas. Kovacs (2002) traduz como "at first bringing joy, then later grief".

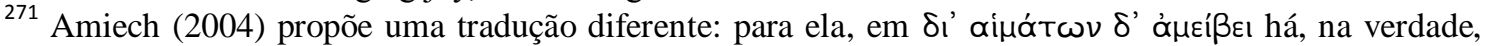
uma tmese, e o verbo seria $\delta 1 \alpha \mu \varepsilon i ́ \beta \varepsilon$. Assim, ela traduz esse verso por "il ajoute um crime aux crimes". Mastronarde (1994, p.444) entende como "acts of bloodshed", assim como Kovacs (2002). Note-se o

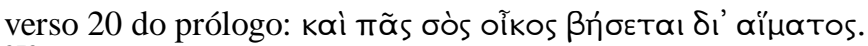

${ }^{272} \kappa \lambda \tilde{n} ו \theta \rho \alpha$ tem o sentido de "porta fechada". Ver verso 64.
} 


\section{$4^{\circ}$ EPISÓDIO}

\section{Mensageiro:}

Olá! Quem se encontra no portão do palácio?

Abri! Trazei Jocasta de seus aposentos.

Mais uma vez: olá! O tempo passa ${ }^{273} \ldots$ Mesmo assim,

sai e ouve, ínclita esposa de Édipo,

cessa as lamúrias e as lágrimas de pesar.

Jocasta:

Meu caro, acaso trazes notícia de desgraça,

a morte de Etéocles, de quem carregavas

o escudo sempre afastando as setas inimigas?

\{Que nova palavra vens tu me anunciar?\}

Está vivo ou morto meu filho? Dá-me um sinal.

\section{Mensageiro:}

Vivo, não temas por isso ${ }^{274}$, pois te livro do medo.

Jocasta:

E, bom ${ }^{275}$, como está a região das sete torres?

Mensageiro:

Permanece intacta. A cidade não foi invadida.

\footnotetext{
${ }^{273}$ Ao contrário de Kovacs (2002), Amiech (2004) e Medda (2006), que entendem a expressão Sı̀̀

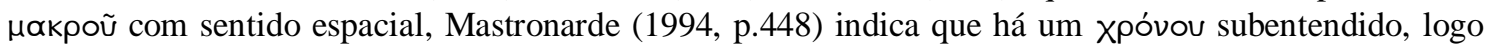
conferindo a expressão um sentido temporal: "even though it is a long interval, nevertheless, come forth, hear". Preferimos a explicação desse estudioso, porque, como sugere o $\mu \alpha^{\prime} \lambda^{\prime}$ a ̛̃̃ $\theta_{15}$ do mesmo verso, o mensageiro deve ter ficado um certo tempo sem receber resposta.

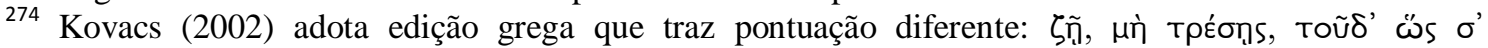
àm $\alpha \lambda \lambda \alpha \dot{\alpha} \xi \omega$ póßou. Amiech (2004) e Medda (2006) adotam pontuação idêntica a de Mastronarde.

${ }^{275}$ Coloquialismo que chama ou reforça a atenção do interlocutor, ver Collard (2005, p.368), que sugere a tradução "Well, and what of that?".
} 
Jocasta:

Mas já passou pelo perigo do ataque argivo?

1080

Mensageiro:

Sim, em seu risco máximo . Mas o Ares dos Cadmeus

fez-se mais forte do que a lança de Micenas.

Jocasta:

Pelos deuses, dize-me ainda uma coisa: sabes algo

sobre Polinices? Isso me aflige: ele ainda vê a luz?

Mensageiro:

Teu par de filhos, até o momento, ainda vive.

1085

Jocasta:

Sejas bendito ${ }^{276}$ ! E como mantivestes afastada

a lança dos argivos dos portões sitiados?

Fala, quero alegrar o velho cego que está

no palácio - nossa terra está a salvo!

Mensageiro A:

Quando o filho de Creonte se matou por esta terra -

no alto da torre, uma espada de negra cor

ele passou na garganta para salvar a cidade -

sete companhias com sete generais

aos sete portões teu filho designou

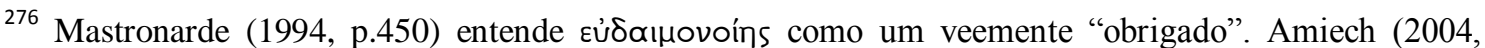
p.191) traduz com o mesmo sentido: "grand merci pour cette nouvelle". Kovacs (2002, p.329) e Medda (2006, p.239) preferem uma tradução mais literal, assim, respectivamente: "blessings on you" e "che tu sia benedetto!". 
a guardar a lança argiva; dispôs reservas, de cavaleiros

contra cavaleiros, hoplitas contra escudeiros,

e assim haveria aos pontos fracos das muralhas

rápida assistência de combate. Do alto da cidadela

vemos o exército argivo de brancos escudos

saído do Teumesso ${ }^{277} \mathrm{e}$, próximo à trincheira,

em corrida eles cercaram a urbe da terra cadmeia.

Os peãs e os trompetes ressoavam igualmente

do lado de lá e do lado de nossas muralhas.

Primeiro conduzia até o portão de Neíste ${ }^{278}$

seu hirto exército de compactos escudos,

Partenopeu ${ }^{279}$, progênie da caçadora,

com emblema familial no meio do escudo:

atalante capturando com flechas certeiras

o javali da Etólia. Nas portas Prétides ${ }^{280}$ avança,

com as vítimas sacrificiais sobre seu carro,

o adivinho Anfiarau ${ }^{281}$ : não traz ele o sinal de

Ýbris, mas armas sobriamente indistintas.

Na entrada Ogigía ${ }^{282}$, o senhor Hipomedonte ${ }^{283}$,

\footnotetext{
${ }^{277} \mathrm{O}$ rio Teumesso dista $8 \mathrm{~km}$ da cidade de Tebas, cf. Medda (2006, p.240). Por outro lado, Amiech (2004, p.486), baseada em escólios da peça, identifica o Teumesso como uma montanha, também situada a $8 \mathrm{~km}$ de Tebas. Segundo Pausânias (9.19.1), Teumesso é um lugar situado na estrada que sai do portão Prétide (ver verso 1109) em direção à cidade de Cálcis, ou seja, a nordeste de Tebas. Ainda segundo o geógrafo, teria sido aí que Zeus escondeu Europa.

${ }^{278}$ Pausânias (9.8.4) aponta duas etimologias possíveis para o nome "neíste": 1)a última corda da harpa se chama nete (vímv), e Anfíão a teria inventado neste portão; 2)Neis seria o nome do filho de Zeto, irmão de Anfião.

${ }^{279}$ Ésquilo, nos Sete, põe Partenopeu nas Portas de Bóreas (527).

${ }^{280}$ Segundo Pausânias (9.8.4), o nome "Prétides" se deve a um cidadão tebano chamado Proteu.Podiam ser vistos aí, no tempo de Pausânias, um teatro e um templo de Dioniso (9.16.6), o túmulo de Melanipo (9.18.1, citado por Ésquilo como um dos sete guerreiros Tebanos Sete, 414), o jazigo dos filhos de Édipo (9.18.3) e o túmulo de Tirésias (9.18.4).

${ }^{281}$ Nos Sete, Anfiarau é posto diante das Portas Homoloides (570).

${ }^{282}$ A respeito do nome desse portão, Pausânias (9.5.1) fornece um dado mítico interessante sobre a origem de Tebas: os primeiros a ocuparem a terra dessa cidade foram os Ectenes, cujo rei se chamava Ogígio, origem do nome do portão. Por essa razão, adiante ele afirma que, de todos os sete portões de Tebas, o nome "Ogígia" é o mais antigo (9.8.5).
} 
avança com emblema no centro do escudo,

Panoptes de olhos manchados, observador,

uns olhos se abrindo com o nascer dos astros,

outros se fechando com seu crepúsculo,

como depois pode-se ver com ele morto.

Posicionado nas portas Homoloides ${ }^{284}$ estava

Tideu $^{285}$, o escudo coberto com pele de leão ${ }^{286}$

e juba eriçada. Na direita, carregava uma tocha,

tal qual Prometeu Titã, para incendiar a cidade.

O teu Polinices às portas Creneias ${ }^{287}$ conduziu

Ares. No escudo como emblema tinha os potros

de Pótnias ${ }^{288}$, correndo e empinando em pânico,

girando engenhosamente por meio de eixos

dispostos perto da alça: pareciam ensandecidos.

O de têmpera bélica não inferior a de Ares,

Capaneu, conduziu sua unidade até as Portas Electras ${ }^{289}$.

Em relevo de férreo ${ }^{290}$ molde, havia em seu escudo

terrígeno Gigante ${ }^{291}$ que nos ombros carregava

\footnotetext{
${ }^{283}$ Nos Sete, Hipomedonte está nas portas de Atena Onca (487) e traz no seu escudo a figura de Tífon (493).

${ }^{284}$ Segundo Pausânias (9.8.6), o nome desse portão se deve a uma circunstância posterior à guerra dos sete contra Tebas. Quando os tebanos foram derrotados pelos argivos na guerra entre os filhos de Etéocles e Polinices, Laodamas (filho de Etéocles) conduziu os tebanos até uma região na Tessália chamada "Homole". Por isso Pausânias (9.8.5) afirma que, dentre os portões tebanos, este foi o último a ser nomeado.

${ }^{285}$ Nos Sete, Tideu está nas portas Prétides (377). Pausânias (9.18.2) relata que, nas portas Prétides, havia três pedras que indicavam o local de sepultamento de Tideu.

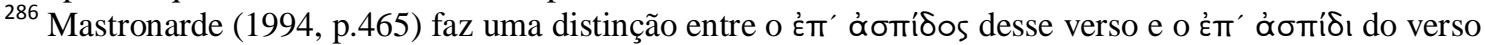
1124. No primeiro caso, tem-se a descrição de algo que cobre o escudo, no segundo, a descrição é de algo pintado.

${ }^{287}$ Nos Sete, é dito apenas que Polinices estava na sétima porta (631). Sobre este portão não se encontra nenhuma informação em Pausânias.

${ }^{288}$ Pausânias (9.8.1-3) informa que em Pótnias, uma região em torno do rio Asopo distando dez estádios de Tebas, há um poço cuja água enlouquece os cavalos que a bebem.

${ }^{289}$ Nos Sete, Capaneu também está situado diante das Portas Electras (422). Segundo Pausânias (9.8.4), o nome deste portão vem do nome de uma irmã de Cadmo, Electra. Seria por esse portão que a estrada de Plateia chegava a Tebas (9.8.7). Pausânias (9.11.1-4) ainda relata que, em seu tempo, podiam-se ver aí as ruínas da casa de Anfitrião, estando o quarto de Alcmena muito bem conservado, a tumba dos filhos de Héracles e um santuário desse herói.

${ }^{290}$ Aqui, segundo Mastronarde (1994, p.467), a imagem pode ser tanto pintada como feita em relevo.
} 
uma cidade inteira com barras retirada de suas bases:

prenúncio para nós do que nossa cidade sofreria.

Na sétima porta estava situado Adrasto ${ }^{292}$,

o escudo repleto com cem pictóricas víboras,

\{carregando no braço esquerdo hidras ${ }^{293}$ \}

sinal da altivez argiva. Ao centro das muralhas

as serpes traziam os filhos dos cadmeus nas garras.

Eu pude contemplar cada uma dessas imagens

ao partilhar as mensagens entre os pastores guerra.

Primeiro, com arcos e dardos de correia

lutamos, com flechas certeiras, projéteis,

chuvas de pedras. Como ganhássemos a luta,

de súbito clamaram Tideu e o teu filho:

"geração de Dânao, antes de sucumbirmos às setas,

por que não atacamos todos juntos as suas portas,

infantaria leve, cavalaria e condutores de carros?

Mal ouviram o grito, ninguém fica desocupado.

Muitos então tombam com a cabeça ensanguentada,

e dos nossos tu verias no chão, diante dos muros,

mergulhões ${ }^{294}$ juntos sorvendo último respiro de vida,

regando a seca terra com jactos de sangue.

O árcade, não argivo, progênie de Atalante,

como um furacão cai nos portões gritando por

fogo e lanças, de modo a destruir a cidade.

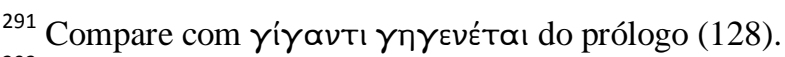

${ }^{292}$ Nos Sete, Adrasto não é contado como um dos Sete. Em seu lugar aparece Etéoclo nas portas Neistas (460). A sétima porta não é nomeada nem por Eurípides nem por Ésquilo nos Sete. Segundo Pausânias

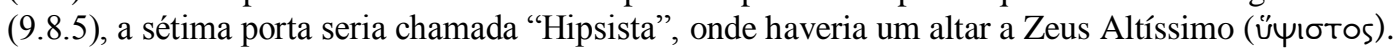

293 Mastronarde (1994, p.470): "Hidra é um famoso emblema pelo qual os argivos podiam orgulhosamente noticiar sua identidade".

${ }^{294}$ Kußıотптńp: segundo Mastronarde (1994, p.472), hapax na tragédia. Ver Ilíada 16.750. Kovacs (2002) e Medda (2006) utilizam o termo, "divers" e "tuffatori", respectivamente. Amiech (2006) traduz como "précipités au sol".
} 
Mas o filho do deus salino contém-lhe a fúria,

Periclimeno, atirando-lhe no rosto pedras da

largura de um vagão do alto de nossa defesa ${ }^{295}$.

Sua cabeça loira ele despedaçou, estilhaçou

as juntas de seus ossos e sua rósea face ${ }^{296}$

cobriu-se de sangue. Nunca mais vivo ele retornará

para sua mãe de belos arcos, moça do monte Menalo ${ }^{297}$.

Quando percebeu que estas portas tinham boa sorte

teu filho foi para outras, e eu o acompanhei.

Vejo Tideu e seu compacto corpo de escudeiros

com lanças etólias atacando a parte mais elevada

das muralhas, de modo que os homens fugiam

e abandonavam seus postos. Teu filho, porém,

como um caçador, de todos os lados os reagrupa

e os reordena nas torres. Para outras portas, então,

acorremos, cessados os estragos desta.

De Capaneu, como falarei de seus desvarios?

Portando longas escadas para as escaladas

ele se aproximava, e de tal maneira se ufanava:

nem mesmo o sacro fogo de Zeus o impediria

de tomar a cidade até a sua parte mais elevada.

Isso ele alardeava enquanto era apedrejado,

e subia, contraindo-se sob o próprio escudo,

calcando os planos degraus de sua escada.

Quando já se apoiava no peitoril da muralha,

\footnotetext{
${ }^{295}$ Segundo Pausânias (9.18.5), é na Tebaida que Periclimeno surge como o matador de Partenopeu. Segundo relato tebano de sua época, Partenopeu teria sido morto por Asfódico.

296 '̋ rosto de Partenopeu. Tradutores interpretam de maneira diferente o sintagma acima. Kovacs (2002): "with the new bloom of youth upon them"; Amiech (2004): "sa joue assombrie par la barbe"; Medda (2006): "le gote da poco fiorite di peluria”.

297 Mastronarde (1994, p.474) prefere "maiden of Mt Maenalum" (monte onde Atalante vivia como caçadora) a "daughter of Maenalus", opção feita por Kovacs (2002), Amiech (2004) e Medda (2006).
} 
Zeus lhe lança um relâmpago: até o solo

ressoa, e todos sentem medo. Da escada, então,

seus membros se esvoaçam um para cada lado,

\{ sua cabeça para o Olimpo, seu sangue para o chão\},

e mãos e pernas, como na roda de Ixíon,

rodam. Seu corpo em chamas cai na terra.

Quando Adrasto ${ }^{298}$ vê Zeus hostil a seu exército,

para fora da vala ele põe o exército dos argivos.

Do nosso lado, ao vermos o propício prodígio

de Zeus, começam a sair os carros, cavaleiros e

hoplitas que, no meio dos guerreiros argivos,

empunham a lança. Tudo de ruim se deu aí.

Morrem e caem os homens de seus carros,

arremessam-se rodas, eixos sobre eixos,

cadáveres vão se empilhando por todos os lados.

Impedimos a destruição de nossas muralhas

até o presente dia. Se é de boa sorte o que

há de vir para esta terra, isso é com os deuses.

Quem a salvou até agora foi um dos numes.

Coro:

É belo o vencer! Se os deuses tiverem, porém,

um plano melhor, terei eu boa sorte ${ }^{299}$.

Jocasta:

As divindades e o destino nos são favoráveis:

\footnotetext{
${ }^{298}$ Adrasto é o último dos sete descrito nessa rhésis. A ordem da apresentação dos guerreiros argivos não coincide com aquela proposta no prólogo (Teichoskopia) nem com a dos Sete Contra Tebas. Ver tabela comparativa em Mastronarde (1994, p.460).

${ }^{299}$ Mastronarde (1994, p.482) considera esses dois versos do coro um "problema insolúvel”. Ele enumera quatro interpretações diferentes para esses versos.
} 
meus filhos estão vivos, e a terra está a salvo.

Parece, porém, que Creonte, do meu casamento

com Édipo está colhendo os males, desgraçado:

privado de seu filho, a pólis teve boa fortuna,

e ele triste infortúnio. Mas retoma o teu relato.

Os meus filhos, o que estão para fazer a seguir?

Mensageiro A:

Deixa de lado o restante. Até aqui tu estás bem.

Jocasta:

O teu falar é suspeito. Não se deixe nada de lado.

Mensageiro A:

Que mais queres além da salvação dos filhos?

Jocasta:

Saber $^{300}$ se quanto ao resto também estarei bem.

Mensageiro A:

Permita-me ir, teu filho está sem escudeiro.

Jocasta:

Tu ocultas algum mal no negror das trevas.

Mensageiro A:

Não quereria falar de males quando te vai tudo bem.

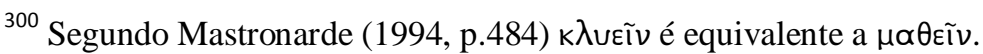


Jocasta:

Sim, vais me contar ${ }^{301}$, a não ser que fujas pelo ar.

\section{Mensageiro A:}

Ai! Por que não me permites partir com o dito

de boa nova, mas me obrigas ${ }^{302}$ a revelar o mal?

Os teus dois filhos estão para lutar - vergonhosa

ousadia! - frente a frente, afastado de todo exército.

Disseram aos argivos e aos cadmeus em comum

coisas que melhor nunca tivessem sido ditas.

Etéocles primeiro, postado no alto de uma torre,

exige que o arauto peça silêncio ao exército ${ }^{303}$ :

\{diz ele: "Generais-de-exército da terra helênica, $\}$

vós, os melhores dos dânaos que viestes até aqui,

e vós, a tropa de Cadmo, não é por Polinices

nem por mim que ides vender vossas almas.

Eu mesmo, a fim de vos livrar deste perigo,

sozinho hei de enfrentar meu irmão em batalha.

Se eu o matar, hei de reger nossa casa sozinho,

mas se for derrotado,entrego a ele a cidade ${ }^{304}$.

Vós, argivos, apartando-se do combate, retornareis

a vossa terra sem deixar uma só vida aqui:

suficiente os corpos dos Semeados que aqui jazem".

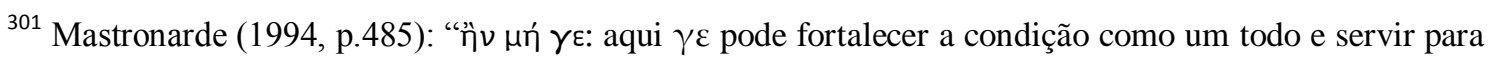
marcar uma afirmação ('sim, você irá me contar') em resposta a negação precedente”.

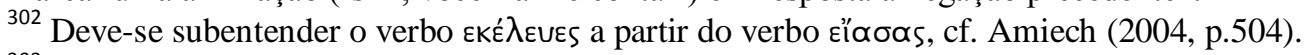

${ }^{303}$ Medda (2006, p.251) entende que é o próprio Etéocles que exige silêncio do exército ("dopo aver ordinato che si bandisse il silenzio all'esercito"), mas Kovacs (2002) e Amiech (2004) entendem que Etéocles o faz por meio do arauto. Mastronarde (1994, p.489) explica que oĩya é uma citação parcial do

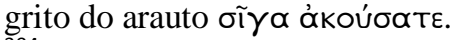

${ }^{304}$ Entre os mais recentes comentadores (e tradutores) da obra, Mastronarde (1994) é o único que utiliza a edição grega

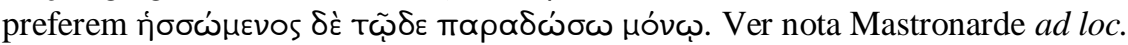


Isso ele falou. Teu filho Polinices deixa com energia

as filas de sua formação e aprova o discurso.

Todos os argivos gritam em resposta, e também

o povo de Cadmo, ambos aceitando a proposta.

Nesses termos eles fazem as libações e, entre

os exércitos, fazem juramentos que os régulos ratificam ${ }^{305}$.

Agora cobrem seus corpos em armamento

de bronze os dois juvenis filhos do senil Édipo.

Amigos os armam: de nossa terra o primeiro é armado

pela elite dos Semeados, aquele pelos melhores dos Dânaos.

Ambos reluziam, nenhum dos dois se fazia pálido,

ferozes que estavam para lançar a lança um ao outro.

De um e outro lado, companheiros que passavam

por eles encorajam-lhes dizendo palavras tais:

"Polinices, a ti cabe erguer a imagem de Zeus

como troféu e conceder um nome de glória a Argos".

Para Etéocles: "O teu combate agora é pela cidade,

obtendo bela vitória agora, regerás o cetro".

Assim eles discursavam e os instavam à batalha.

Os adivinhos sacrificavam cabras, observando

a textura do fogo sacrificial, um flamejar adverso,

e as pontas da chama, que indicavam duas sortes:

ou sinal de vitória, ou o sinal dos derrotados.

Mas se tens alguma força, palavra de sabedoria,

ou canto encantatório, vem, impede o terrível

conflito dos filhos. O perigo é extremo, e o

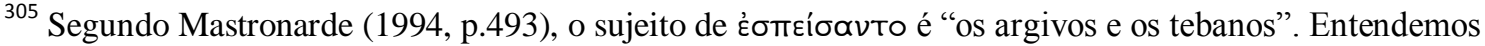
que também para o verbo ouvĩ $\propto \alpha v$ o sujeito seja "os argivos e os tebanos". Kovacs (2002), porém, para

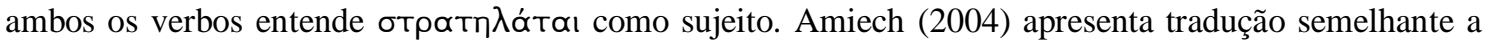

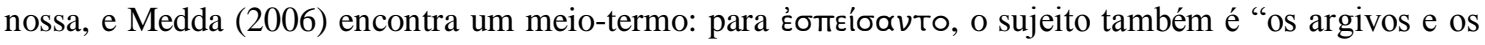

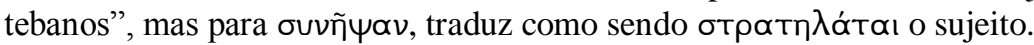


prêmio terrível: lágrimas para ti hão de vir

se fores privada dos dois filhos em um só dia.

Jocasta:

Filha, Antígone, sai, vem para frente do palácio.

Não é para danças corais ou melindres de moça

que a vontade divina te move nesse momento,

mas teus dois irmãos, homens excelentes, estão

caminhando para a morte e tu precisas impedir,

junto com tua mãe, que eles se matem um ao outro.

Antígone:

Minha mãe, minha genitora, que funesta novidade

alardeias tu aos teus aqui diante do palácio?

Jocasta:

Ó filha, a vida de teus irmãos está por um fio ${ }^{306}$.

Antígone:

Jocasta:

Como dizes?

Um a um, pela lança, eles se enfrentam.

Antígone:

Jocasta:

Ai de mim! Que dizes, mãe?

Nada de bom, mas vem comigo.

Antígone:

Jocasta:

Ir aonde, deixando o gineceu?

Para o campo de batalha.

1275

${ }^{306}$ Kovacs (2002), Amiech (2004) e Medda (2006) traduzem Éppєı com aspecto perfeito “está acabada, está terminada". Mastronarde (1994, p.503) nota, porém, que, nesse caso, o verbo apresenta um aspecto progressivo de tempo presente, pois Jocasta ainda vê uma chance de salvar seus filhos. Mesmo verbo em Medeia (114). 
Antígone:

Envergonha-me a multidão.

Antígone:

E farei o quê lá ${ }^{307}$ ?

Antígone:

De que modo, mãe?
Jocasta:

Pudicícia não é o caso agora.

Jocasta:

Dissolver a rixa dos irmãos.

Jocasta:

Ajoelhando-se comigo.

Jocasta:

Tu, leva-nos ao campo de batalha! Não tardemos.

Apressa-te, apressa-te, filha! Se alcanço meus filhos

antes da luta, minha vida ainda verá a luz do dia,

mas se eles morrem, jazerei morta lá também ${ }^{308}$.

\section{QUARTO ESTÁSIMO}

Coro:

Str.

Ai , ai de mim! Tremendo de medo,

tremendo está meu coração: na minha

pele

sinto piedade, piedade pela mãe dolorosa.

Qual dos dois filhos sangrará do outro -

ai, dores minhas,

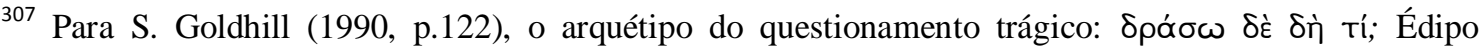
também se vê nesse tipo de questionamento em 1615.

${ }^{308}$ Mastronarde (1994, p.504) refuta a tradução de Craik (1988) "shall lie over their bodies". Mas Kovacs (2002), Amiech (2004) e Medda (2006) apresentam traduções semelhantes, respectivamente: "i shall lie next to them in death", "je serai étendue morte à leurs côtés", e "io giacerò morta accanto a loro".
} 
a garganta irmã, a alma irmã,

por feral unir-se de armas ${ }^{309}$ ?

Pobre de mim, pobre,

que cadáver arruinado chorarei?

Ant.

Ai, torvo sofrer ${ }^{310}$ ! Gêmeas bestas,

1296

almas homicidas, pela lança brandida,

logo nos trazem quedas sangrentas.

Pobres coitados, o que tenha os levado à ideia de

combate singular,

Com um grito bárbaro,

estridor de dor,

lamuriarei com lágrimas que se devem aos mortos.

O destino está próximo, perto o morticínio.

O gládio decide o futuro.

Aziago, aziago o massacre vindo das Erínias.

Mas eis que vejo Creonte aqui, anuviado,

aproximando-se do palácio. É hora de cessar o choro.

\section{QUINTO EPISÓDIO}

Creonte:

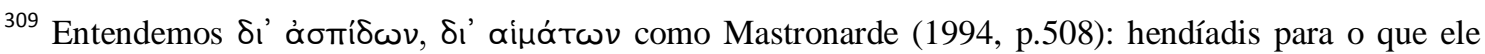
traduz como "in bloody armed battle". Kovacs (2002) traduz literalmente, sem hendíadis.

${ }^{310}$ Interpretamos a interjeição $\delta \tilde{\alpha}$ como uma forte exclamação de horror, cf. Mastronarde (1994, p.509).
} 
Ai de mim, que fazer? Por mim mesmo ou

pela cidade verto lágrimas? Uma tal nuvem

a envolve de modo a conduzi-la ao Aqueronte.

Meu filho está morto, deu a vida pela pátria,

e obteve um nobre nome - para mim doloroso.

Há pouco o retirei do penhasco do dragão

e o pobre suicida eu carreguei nos braços.

Toda minha casa grita. Eu venho, ancião,

até minha velha irmã Jocasta, para que ela

banhe e prepare meu filho para o enterro,

pois os não mortos precisam, honrando

aqueles que morreram, venerar o deus ctônio.

Corifeu:

Tua irmã já deixou o palácio, Creonte,

e, no mesmo passo, foi Antígone, sua filha.

Creonte:

Para onde? E por qual circunstância? Fala!

Corifeu:

Seus filhos, ela ouviu, iam às armas,

num combate singular, pela casa real.

Creonte:

Como dizes? Eu estava velando o cadáver

de meu filho, não vim a saber de nada disso.

Corifeu: 
Mas tua irmã já saiu há algum tempo.

Penso que a luta de vida ou morte, Creonte,

já tenha sido travada pelos filhos de Édipo.

Creonte:

Ai de mim! Já posso avistar o sinal aqui,

o semblante e o olhar consternado do mensageiro

aproximando-se para anunciar todo o ocorrido.

Mensageiro B:

Pobre de mim. Que discurso ou lamúria proferir?

Creonte:

Está feito! Começas o relato sem belo prólogo.

Mensageiro B:

Pobre de mim, de novo digo! Grandes são os males que trago.

Creonte:

Além de outros que já ocorreram... Mas que dizes?

Mensageiro B:

Os filho de tua irmã estão mortos, Creonte.

Coro:

Ai, ai!

Grandes penas alardeias para mim e para a cidade.

Creonte: 
Palácio de Édipo, ouvistes isso?

Pereceram teus filhos pela mesma desgraça.

Coro:

Sim, e muito choraria, se estivesse consciente.

Creonte:

Ai de mim, eventos do mais penoso destino!

\{Ai de mim! Pobre infeliz que sou!

Mensageiro:

Se ao menos soubesses os males além desses...

Creonte:

Como poderiam ser mais desditosos que esses?

Mensageiro:

Tua irmã está morta junto com os dois filhos.

Coro:

Ressoai, soai a lamentação pelos

golpes da mão branca na cabeça.

Creonte:

Infeliz Jocasta, que fim de vida e de matrimônio

tu sofreste por causa dos enigmas da Esfinge.

Como se deu entre os irmãos o morticínio, cizânia

originada pelas imprecações de Édipo? Diga-me. 


\section{Mensageiro B:}

Já conheces os sucessos diante das torres

de Tebas. Não está longe o contorno das muralhas -

de modo que conheces todo o ocorrido.

Revestidos os corpos com as brônzeas armas,

os jovens filhos do velho Édipo

postaram-se no ponto médio entre os exércitos -

\{os dois estrategos, os dois estrategistas \} -

para o combate individual em luta de lanças.

Os olhos em Argos, Polinices faz sua oração:

"senhora Hera, posse tua eu me fiz após me casar

com a filha de Adrasto e ter seu sítio habitado.

Conceda-me matar meu irmão e banhar em

sangue minha mão direita, hostil e vitoriosa".

Ele quis a mais vergonhosa coroa, matar um irmão.

os soldados tinham lágrimas no rosto por causa de

tal sina, e eles todos trocavam olhares entre si.

Etéocles, por sua vez, tinha os olhos no templo

de Palas do escuro-dourado e orou: "Filha de Zeus,

conceda a mim arremessar com essas mãos

a lança vitoriosa no peito de meu irmão.

\{E matar quem veio aqui destruir minha pátria.\}

Quando, como tocha acesa, clangor de trombeta

etrusca soou, sinal de batalha sangrenta,

eles se lançaram um contra o outro numa terrível corrida.

Como javalis de selvagens presas afiadas, os dois

encontraram-se, as barbas molhadas de espuma.

Atacavam-se com as lanças, mas se agachando atrás 
dos escudos, o ferro aferroava sem dano.

Se um via os olhos do outro desprotegido,

mirava a lança ${ }^{311}$ a fim de ferir o primeiro golpe.

Mas ambos levavam os escudos ornados

até os olhos, e o golpe saía inócuo.

Mais suavam aqueles que observavam a luta

do que os que a lutavam, por medo aos amigos.

Etéocles, pondo de lado com o pé uma pedra

1390

que estava no seu caminho, deixou a perna

para fora do escudo. Polinices avançou com a lança,

vislumbrando um ataque com sua arma:

sua lança argiva atinge a perna do irmão.

Todo o exército dânao bradava em euforia.

Nesse momento, o primeiro a se machucar

percebe o tronco nu de Polinices e atinge a lança

no peito dele. Grande satisfação ele dá

aos cidadãos de Cadmo, mas sua lança se quebra.

Ficando sem sua lança, ele sai em retirada,

pé ante pé. Apanhando uma grande pedra, atira-a

e quebra ao meio a lança do outro. Ares iguala

os dois, ambas as mãos inermes mostrando-se.

Tomados então os punhais ao punho,

um contra o outro, entrechocam-se os escudos,

forte fragor de luta formando-se entre eles.

De alguma forma lembrou Etéocles o estratagema

tessálio, pois lá já estivera, e resolve usá-lo.

Pondo-se à parte do combate em decurso,

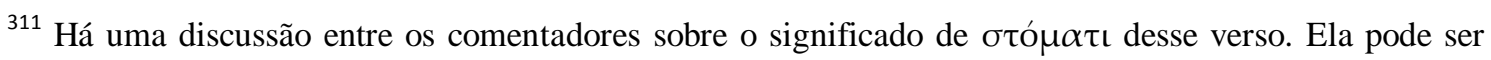

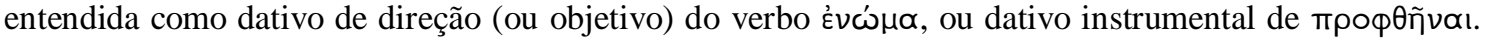
Adotamos essa última.
} 
movimenta seu pé esquerdo para trás

e protege a região do ventre pela frente.

Em seguida, avança com o pé direito e atira

a espada no umbigo, cravando-a até as vértebras.

Curvado sobre as costelas e o abdômen, o pobre

Polinices cai com o corpo a jorrar sangue.

Etéocles, como o vencedor da batalha,

lança sua espada no solo e despoja o irmão,

prestando atenção não a ele, somente ao roubo.

Custou-lhe caro: ainda com um respiro frouxo,

Polinices mantivera a espada apesar da queda.

Com muito esforço, então, fere com a espada

o que primeiro caiu, Polinices, o fígado de Etéocles.

Ambos caem mordendo o chão, um do lado

do outro, e não conseguem resolver o embate.

Coro:

Ai! Como eu lamento teus males, Édipo!

Parece que o deus cumpriu tuas maldições.

Mensageiro B:

Mas ouve ainda outros males além desses.

Quando $^{312}$ os filhos ali caídos deixavam a vida, nesse momento a infeliz mãe deles chegou, \{juntamente com sua filha, a passos largos, \}

e, ao ver os filhos feridos de golpes mortais, chorou: "Crianças, chego tarde para ajudá-los."

Caindo então ao redor dos filhos, pôs-se

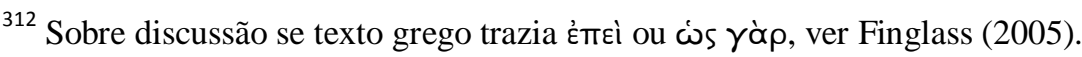


a chorar, a gemer, lamentando pela dor

de os ter amamentado. A irmã a apoiava:

“ó amparo da velha mãe, ó irmão queridos

que não verão minhas bodas". No peito

o senhor Etéocles traz uma respiração difícil.

Ele ouve sua mãe e lhe dá sua lânguida mão;

som algum pronuncia, mas dos olhos

as lágrimas falavam palavras de ternura.

Polinices, ainda respirando, volta o olhar para a irmã e para a idosa mãe e lhes fala:

“estou perdido, mãe. Sinto muito por ti,

pela minha irmã e por irmão já morto:

irmão tornou-se inimigo, ainda assim era irmão.

Sepulta-me, mãe, e também tu, minha irmã,

em chão pátrio, e a cidade encolerizada comigo

acalmai, para que eu obtenha uma porção

do chão pátrio, embora tenha arruinado minha casa.

Fecha meus olhos com tuas mãos, mãe" -

e ele mesmo as põe sobre os seus olhos -

“e adeus: as trevas já estão ao meu redor".

Assim ambos expiraram ao mesmo tempo.

A mãe, então, ao perceber tal desfecho,

hiper-sofrida, tomou a espada dos mortos

e fez o impensável: no meio do pescoço

cravou o ferro e, entre os seus entes mais

queridos, caiu morta, abraçando a ambos.

Os exércitos se ergueram em discórdia,

nós reclamando a vitória para nosso líder, eles para o deles. Havia discórdia entre os chefes, 
uns dizendo que Polinices ferira primeiro com a lança, outros que não havia vitória porque ambos morreram. Antígone então deixa o exército discretamente.

Os soldados logo se armaram. Por feliz previdência, o exército de Cadmo sentava-se próximo dos escudos. Assim premunidos, atacamos primeiro o exército argivo ainda não preparado com as armas.

Ninguém resistiu: os fugitivos preencheram todo o campo, e o sangue corria dos milhares de cadáveres tombados pelas lanças. Ao vencermos, uns erguiam a imagem de Zeus como troféu, outros, pilhando os escudos dos cadáveres argivos, levavam todo o espólio para dentro dos muros.

Outros, junto com Antígone, levavam os corpos dos mortos para dentro para serem pranteados. Na cidade, uns saíram como os mais felizes, finda a luta, outros como os mais infelizes.

\section{Coro:}

Não mais por ouvir dizer a desgraça

do paço vem. Vê-se já

os corpos dos três mortos

diante do palácio; morte comum

leva-os para as eternas tênebras.

Antígone:

Não é cobrindo a delicada pele de meu rosto envolto de cachos 
nem me envergonhando do rubor sob meu olhos,

meu rosto avermelhado, que eu venho aqui como

bacante dos mortos: lanço longe o véu

de meus cabelos e dispenso essa coloração

festiva $^{313}$ de meu vestido.

Sou a dolorida líder desses mortos. Ai, ai de mim!

Polinices, fizeste valer teu nome ${ }^{314}$ ! Ai de mim, Tebas!

Tua luta - não foi uma luta, mas um morticínio -

destruiu a casa de Édipo, cumprindo o oráculo ${ }^{315}$,

com terrível derramar de sangue,

lúgubre derramar de sangue.

1497bis

Que tipo de canção

ou que lamento musical

eu devo evocar entre

essas inúmeras lágrimas, casa, ó casa?

Trago três membros mortos de minha família,

mãe e seus filhos, joguete das Erínias.

Elas destruíram a casa de Édipo por completo

quando ele resolveu o astuto enigma

da rude e incompreensível Esfinge,

matando a aeda em seguida.

Ai de mim, pai,

que outra grega ou bárbara

ou bem-nascida de outrora,

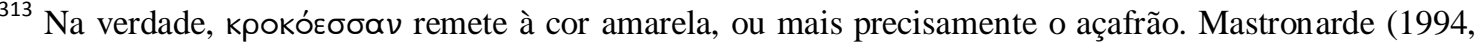
p.565) nota que essa cor é associada à festividade, luxo e feminilidade. No português tal associação não é imediata, nem necessária, daí não optarmos pela tradução literal.

${ }^{314}$ Ver interpretação etimológica do nome Polinices nos versos 636-7.

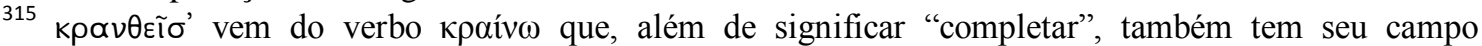
semântico relacionado ao universo religioso dos oráculos. De fato, Mastronarde (1994, p.566) assim entende o significado integral do verbo neste verso: "completou <por meio de uma força sobrehumana>". Amiech (1988) e Medda (2006), contudo, traduzem sem levar em conta tal conotação

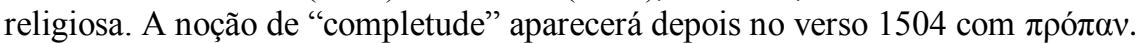


quem sofreu males tais,

dores públicas

de humana desventura?

Infeliz, grito dores!

Que ave em sua árvore,

ou pousada nas altas folhas de um pinheiro,

piando pela falta de sua mãe,

fará eco aos meus lamentos?

Meu canto de dor

eu choro abertamente

por ter de levar uma vida para sempre solitária

em meio à torrentes de lágrimas.

\{Vou bradar ai!\}

pelo que primeiro devo ofertar

meus cabelos dilacerados?

Pelos gêmeos seios lactantes

de minha mãe

ou pelos mutilados,

arruinados corpos de meus irmãos?

Ai, ai! Deixa teus

aposentos, traz teu cego olhar,

anoso pai, mostra,

Édipo, tua existência perdida.

Atiraste outrora aos olhos esvoaçante

escuridão; agora, estás condenado à longa vida de lavor.

Tu que faz vagar

pelo paço teu velho pé

1536bis

ou que repousas, 
miserável, em teu catre, ouves-me?

Édipo:

Por que me conduzes para a luz, filha,

meu cego pé apoiado por bastões,

tirando-me da cama de meu quarto de

trevas com teu piíssimo choro?

Sou uma cinza, esquálida imagem

de éter, ínfero cadáver,

um sonho alado, esvoaçante.

Antígone:

Ouvirás o relato de uma triste

notícia, pai: teus filhos não vêem

mais a luz, nem tua esposa, que, com o auxílio

de teus bastões, conduzia a duras penas teu cego pé.

Pai, ai de mim!

Édipo:

Ai, como sofro! Diante disso padeço,

grito de dor.

Três vidas! Que sina, como elas deixaram

assim a luz, filha, fala.

Antígone:

Falo: sem te censurar, sem me comprazer

na fala, mas condoída, digo: tua Vingança,

repleta de espadas,

incêndios e lutas cruentas, atingiu os teus filhos, 
pai, ai de mim!

Édipo:

Antígone:

Ai... Ai!

Por que gemes assim?

1560

Édipo:

Antígone:

Meus filhos...

Andas em dores...

Antígone:

E se tu ainda visses a quadriga

do Sol, a estes corpos defuntos

a luz dos teus olhos contemplaria?

Édipo:

Mas é visível o mal dos meus filhos.

A minha pobre esposa, porém, filha, que sina a perdeu?

Antígone:

Tristes lágrimas a todos ela mostrou,

e aos filhos levou, levou,

suplicante, o seio súplice.

Mãe, ela encontrou os filhos na porta Electra,

num campo de lótus, entre as lanças

de uma luta comum,

tal como leões entocados,

lutando apesar das feridas. Libação

fria, funesta, de sangue já

obtida por Hades, conduzida por Ares. 
Tomando a espada de bronze dos cadáveres,

ela a afunda em seu corpo e gemendo cai entre os filhos.

Tudo isso em um dia foi conduzido

para nossa casa, pai, por um Deus

que cuidou de as executar.

1581

Coro:

Hoje foi o dia em que muitos males se iniciaram

na casa de Édipo: pudesse a vida ser mais venturosa.

\section{Creonte:}

Cessem as lamentações agora; é hora ${ }^{317}$ de se cumprir

os ritos fúnebres. Este pronunciamento, Édipo,

escuta: Etéocles, teu filho, concedeu-me o poder

sobre esta terra, quando ele deu o dote de matrimônio

e o leito de sua filha Antígone para Hemom.

Portanto, não mais permitirei que tu vivas aqui.

Perspícuo foi o falar de Tirésias: nunca, jamais

a cidade prosperará se tu habitares esta terra.

Vai, parte daqui. Isso eu não ordeno por arrogância

ou por ser teu inimigo, mas por temer que as pragas

tuas venham a causar um novo mal à terra.

Édipo:

Ó Fado, desde o início, como me fizeste desditoso!

\{E desgraçado, como a nenhum outro fizeras. $\}$

\footnotetext{
${ }^{316}$ O texto a partir desse verso até o fim é julgado por alguns como inautêntico. Kovacs (2002), por exemplo, coloca todo esse trecho entre colchetes, mas Amiech (2004) advoga pela autenticidade do trecho.

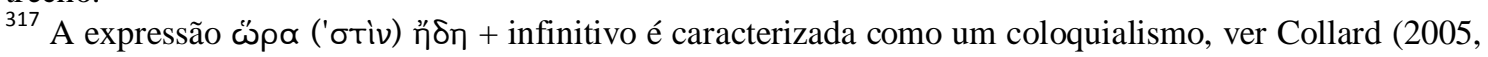
p. 370), que sugere a tradução "it's already high time to...".
} 
Antes mesmo de vir à luz pelo ventre materno, Apolo profetizava a Laio que eu, ainda inato, tornar-me-ia assassino de meu pai. Ai de mim. Assim que nasci, meu pai, aquele que me gerou, 1600 tenta me matar, julgando ter gerado inimigo seu fadado estava a ser morto por mim. Faz de mim, inda lactente, mas já desditoso, pasto de feras. Disso fui salvo - mas mais valia que o Citerão precipitasse-se no insondável abismo do Tártaro.

Ele não me matou, mas como um serviçal

o deus me designou no paço de Políbio.

Desgraçado, eu tiro a vida de meu próprio pai, deito-me no leito conjugal de minha mãe, gero filhos que são meus irmãos, arruíno-os, transmitindo aos dois as maldições de Laio. Não sou tão insensato a ponto de ter tramado tais desgraças para os meus olhos e para a vida de meus filhos sem a indução de um dos deuses. Que seja. Que farei eu agora, desgraçado?

Quem fará companhia para os meus passos cegos?

Esta morta? Decerto a faria, se estivesse viva. Meus dois belos filhos? Não mais me pertencem. Sou jovem ainda para garantir minha subsistência? Impossível! Por que com tanto ardor me matas, Creonte? Pois me matas, se me expulsas de minha terra. Não vou cingir teus joelhos com minhas mãos para não parecer vil. Nunca trairia a minha nobre estirpe, muito embora esteja em desgraça. 
Creonte:

Disseste bem: tu não tocarás meus joelhos,

pois eu não te permitiria habitar esta terra.

Quanto aos mortos, mister é agora conduzir este

para o palácio, mas aquele, o cadáver de Polinices,

que veio com outros para destruir a pólis,

seja lançado insepulto fora dos limites desta terra.

anuncie-se isto para todos os cadmeus:

se alguém ornamentar o cadáver com coroas

ou se o cobrir com terra, sua paga será a morte.

\{Deixem-no sem pranto, sem jazigo, aos pássaros $\}$

tu, Antígone, cessa o pranto pelos três mortos

e prepara-te para reingressar ao palácio.

\{Conserva-te aí inupta, esperando o dia marcado

chegar, quando enfim se unirás a Hemom.\}

Antígone:

Pai, jazemos em males insuportáveis!

Lamento mais por ti do que por esses mortos.

Dos teus males, não há um pesado, outro leve,

mas nasceste desditoso por completo, pai.

Mas a ti eu pergunto, recém eleito líder:

por que injurias meu pai expulsando-o daqui?

Por que formulas tais leis acerca de um morto?

Creonte:

Tais são as deliberações de Etéocles, não minhas.

Antígone: 
São insensatas, por certo, e tu tolo de cumpri-las.

Creonte:

Como? Não é justo executar o que lhe foi ordenado?

Antígone:

Não, se é algo indigno e sordidamente pronunciado.

Creonte:

O quê? Não é justo ser este homem lançado aos cães?

Antígone:

É ilegítima a pena que tu conferes a ele.

Creonte:

Não: não sendo ele inimigo da cidade, tornou-se.

Antígone:

Ele não já pagou com seu destino perante o deus?

Creonte:

Que ele pague seu castigo também com seu jazigo.

Antígone:

Por qual erro, se ele veio pela sua parte da terra?

Creonte:

Já sabes que este homem permanecerá insepulto. 
Antígone:

Hei de enterrá-lo, mesmo a cidade proibindo.

Creonte:

Cavarás a própria cova junto a deste cadáver.

Antígone:

É boa fama dois irmãos jazerem juntos.

Creonte:

Prendei esta menina e conduzi-a até o palácio.

Antígone:

De forma alguma! Não abandonarei este cadáver.

Creonte:

O nume decidiu, menina, não conforme teu parecer.

Antígone:

Também isto foi decidido, não se ultrajar os mortos.

Creonte:

Ninguém há de pôr úmida terra ao redor do morto.

Antígone:

Sim, suplico-te, Creonte, pela minha mãe Jocasta!

Creonte:

Em vão tu te perturbas: nunca conseguirás obtê-lo. 
Antígone:

Permite-me ao menos dar-lhe os banhos rituais.

Creonte:

Eis uma das proibições impostas na cidade.

Antígone:

Ao menos enfaixar seus brutos ferimentos.

Creonte:

Não hás de prestar qualquer honra ao cadáver.

Antígone:

Meu querido irmão, ao menos tocarei teus lábios.

Creonte:

Vais arruinar teu casamento por causa de um lamento?

Antígone:

Acaso, nesta vida, caso com teu filho algum dia?

Creonte:

No teu caso, é forçoso: para onde fugirias do enlace?

Antígone:

Certamente tal noite me fará uma das danaides.

Creonte: 
Percebes a insolência com que ela me ultraja?

Antígone:

Seja minha espada a prova de meu juramento.

Creonte:

Por que tanto almejas o fim deste casamento?

Antígone:

Exilar-me-ei com meu pai desventurado.

Creonte:

Há nobreza nos teu atos, e um certo desvario.

Antígone:

Para que saibas mais, morro também junto dele.

Creonte:

Vai, deixa esta terra. Não matarás meu filho.

Édipo:

Minha filha, agradeço teu zelo para comigo.

Antígone:

Se eu me casasse, pai, partirias sozinho daqui?

Édipo:

Tua felicidade está aqui. Meus males, eu os suporto. 
Antígone:

E quem te auxiliaria, pai, tu que estás cego?

Édipo:

Onde tombar, aí jazerei: eis minha moira.

Antígone:

Mas onde está Édipo e os seus famosos enigmas?

Édipo:

Perdido. Em um dia fui feliz, em um dia me arruinei.

Antígone:

E não é mister que eu tome parte em teus males?

Édipo:

É vergonhoso uma filha se exilar com um pai cego.

Antígone:

Não: se a filha é sensata, pai, é um ato nobre.

Édipo:

Guia-me, então, filha, quero tocar tua mãe.

Antígone:

Aqui, toca o rosto da mulher que tu mais amaste.

Édipo:

Ó mãe, ó mais infeliz cônjuge! 
Antígone:

Malfadada ela jaz, circundada só por males.

Édipo:

E os corpos de Etéocles e Polinices, onde estão?

Antígone:

Lado a lado, perto de ti, eles jazem estendidos.

Édipo:

Põe minha cega mão nestas faces desditosas.

Antígone:

Pronto, segure tua mão os filhos mortos.

Édipo:

Meus caros caídos, infelizes filhos de um infeliz.

Antígone:

Muitíssimo caro para mim é o nome ${ }^{318}$ de Polinices.

Édipo:

Agora, filha, o oráculo de Lóxias está se cumprindo.

Antígone:

Qual tu dizes ${ }^{319}$ ? Há ainda outros males além desses?

\footnotetext{
${ }^{318}$ Aqui, A edição de Mastronarde traz ö $\mu \mu \alpha$, "olho".

${ }^{319}$ Moíos precidido de artigo caracteriza uma expressão coloquial que reforça o contato entre os falantes, ver Collard (2005, p.368).
} 
Édipo:

Como um errante, devo morrer em Atenas.

Antígone:

Onde? Que urbe da Ática há de te hospedar?

Édipo:

A sacra Colono, morada do deus do cavalo.

Mas vamos, sê o auxílio deste teu cego pai,

já que desejas ser minha parceira de exílio.

Antígone:

Vai para o exílio aviltante. Dá-me tua mão,

pai ancião, e faz de mim tua

guia, como o vento o é para o navio.

Édipo:

Sim,

eu parto, filha. E tu,

1714bis

sê a infeliz guia de meus pés.

Antígone:

Tornei-me ${ }^{320}$ a infeliz

de todas as meninas tebanas.

Édipo:

Onde ponho meu passo senil?

\footnotetext{
${ }^{320}$ Conforme vemos na edição de Mastronarde, após o segundo $\gamma \varepsilon v o ́ \mu \varepsilon \theta \propto$ existe uma vírgula que torna
}

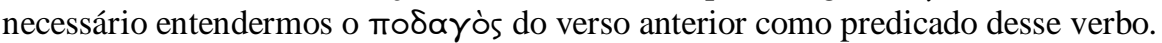


Para onde levar meu báculo, filha?

Antígone:

Aqui, aqui, vem comigo,

aqui, aqui, põe teu pé,

és fraco como um sonho ${ }^{321}$.

Édipo:

Ai, tristíssimo desterro:

eu, velho, devo vagar longe da pátria.

Ai, é terrível, terrível o que sofro.

1725

Antígone:

Por que "sofro"? Por que? Justiça não vê os maus,

nem retribui a insensatez dos homens.

Édipo:

$\mathrm{Eu}$ sou aquele que obteve o canto

de vitória, aquele que atingiu o céu

por ter resolvido o ininteligível

enigma da virgem mulher.

Antígone:

${ }^{321}$ Literalmente, "tendo a força de um sonho", mas Mastronarde (1994, p.632) explicita a expressão traduzindo-a para "being as weak as a dream" e explica: "uma imagem convencional para a fraqueza da idade". 
Para que mencionar a Esfinge?

Não fales sobre os "bons tempos" de outrora.

Esta tribulação já te espreitava:

tornar-se pária da própria pátria,

pai, para morrer algures.

Deixo minhas lágrimas de saudade

pelas amigas e parto para longe da pátria,

vagando sem identidade.

Édipo:

Tens uma atitude positiva.

Antígone:

O renome me dispõe

para a desgraça paterna.

Desgraçam-me os ultrajes contra ti e o irmão.

Este deixou o lar e ora jaz insepulto,

mas, mesmo que eu precise morrer, pai,

hei de o enterrar nas trevas da terra.

Édipo:

Vai ter com as de tua idade.

Antígone:

Já tive o suficiente sofrer.

Édipo:

Tu, as orações nos altares... 
Antígone:

Já basta de chorar.

Édipo:

Vai até Brômio e ao sagrado local

onde as mênades estão, nas montanhas.

Antígone:

Dioniso? A quem eu outrora,

vestida com cadmeia pele de cervo,

dancei nas montanhas

com o sagrado tíaso de Sêmele,

rendendo não correspondidas graças aos deuses?

Édipo:

Cidadãos desta ilustre terra, atentai, eis aqui Édipo,

o que ilustres enigmas resolveu, o maior dos homens,

o que sozinho superou a força da Esfinge assassina.

Agora, sem honra, digno de pena, sou expulso da terra.

Mas por que lamentar tais fatos, por que chorar em vão?

A um mortal é preciso suportar os desígnios dos deuses.

Coro:

Grande e veneranda Vitória,

que tu minha vida sempre governes,

sem cessar de coroá-la. 


\section{REFERÊNCIAS BIBLIOGRÁFICAS}

AGARD, W. Boreas at Athens, The Classical Journal, Vol. 61, No. 6 (Mar., 1966), pp. 241-246.

ALLAN, W. Euripides. Helen. Cambridge, Cambridge University Press, 2008.

AMIECH, C. Les Phéniciennes d'Euripide: Commentaire et Traduction. Paris: L’Harmattan, 2004.

ARTHUR, M. "The curse of Civilization: The Choral Odes of the Phoenissae", Harvard Studies in Classical Philology, Vol. 81 (1977), pp.163-185.

ASHERI, D.; LLOYD, A. A commentary on Herodotus Books I-IV. Oxford: Oxford University Press, 2007.

AUBRIOT, D. Prière et Conception Religieuse en Grèce Ancienne. Maison de l'Orient Méditerranéen, 1992.

BALDRY, H. The Dramatization of the Theban Legend. Greece \& Rome, Second Series, Vol. 3, No. 1 (Mar., 1956), pp. 24-37.

BARAGWANATH, E., BAKKER, M. Myth, Truth, and Narrative in Herodotus. Oxford, Oxford University Press, 2012.

BARRETT, W. S. Euripides. Hippolytos. Oxford: Oxford University Press, 1964.

BERMAN, D. The Double Foundation of Boiotian Thebes. Transactions of the American Philological Association (1974-), Vol. 134, No. 1 (Spring,2004), pp. 1-22.

BERTELLY, L. "Hecataeus: From Genealogy to Historiography". In: LURAGHI, N. (ed.). The Historian's Craft in the Age of Herodotus. Oxford: Oxford University Press, 2001.

BIERL, A. Ritual and Performativity. The Chorus of Old Comedy. (trad. Alexander Hollmann) Cambridge, Harvard University Press, 2009. 
BREMMER, J. Interpretations of Greek Mythology. Surry Hills, Croom Helm Ltd. 1987.

BRISSON, L. How Philosophers Saved Myths. Allegoric Interpretation and Classic Mythology. Chicago, The University of Chigaco Press, 2004.

. Plato The Myth Maker (trad. Gerard Naddaff). Chicago, The University of Chigaco Press, 1998.

BUIJS, J. Studies in the Lyric Metres of Greek Tragedy. Mnemosyne, Fourth Series, Vol.38, Fasc. 1/2 (1985), pp.62-92.

BURIAN, P. "Myth into muthos: the shaping of tragic plot". In: Easterling, P.E. (ed) The Cambridge Companion to Greek Tragedy. Cambridge: CUP, 1999, p.178-208.

BURGESS, D. "The Authenticity of the Teichoskopia of Euripides' 'Phoenissae", The Classical Journal, Vol. 83, No. 2 (Dec., 1987 - Jan., 1988), pp. 103-113.

BURKERT, W. Savage Energies. Lessons of Myth and Ritual in Ancient Greece (trad. Peter Bing). Chicago, The University Of Chicago Press, 2001.

. "Seven against Thebes: an Oral Tradition between Babylon Magic and Greek Literature", IN: BRILLANTE, C., I poemi epici rapsodici non Omerici e la tradizione orale, Editrice Antenore, Padua, 1981.

Structure and History in Greek Mythology and Ritual. Berkeley, University of California Press, 1979.

BUXTON, R. Imaginary Greece: the contexts of mythology. Cambridge, Cambridge University Press, 1994.

CALAME, C. "From Choral Poetry to Tragic Stasimon: The Enactment of Women's Song". Arion, Third Series, Vol. 3, No. 1, The Chorus in Greek Tragedy and Culture, One(Fall, 1994 - Winter, 1995), pp. 136-154.

The Craft of Poetic Speech in Ancient Greece (trad. Janice Orion). Ithaca and London, Cornell University Press, 1995 b.

Greek Mythology: Poetics, Pragmatics and Fiction (trad. Janet Lloyd). Cambridge, Cambridge University Press, 2009. 
. "Mythologiques de G.S. Kirk: Structures et fonctions du mythe". Quaderni Urbinati di Cultura Classica, No. 14 (1972), pp.117-135.

CARTLEDGE, P. "The Greek Religious Festivals", in: EASTERLING P., MUIR, J. Greek Religion and Society. Cambridge, Cambridge University Press, 1985.

CERBO, E. "Due scene "Liriche" dalle "Fenicie" di Euripide (vv. 1485-1538 e 15391581)". Quaderni Urbinati di Cultura Classica, New Series, Vol. 32, No. 2 (1989), pp. $67-75$.

CHONG-GOSSARD, J. "Song and the Solitary Self: Euripidean Women Who Resist Comfort". Phoenix, Vol. 57, No. 3/4 (Autumn - Winter, 2003), pp. 209-231

COLLARD, C. "Colloquial Language in Tragedy: A Supplement to the Work of P. T. Stevens”. The Classical Quarterly, Vol. 55, No. 2 (Dec., 2005), pp. 350-386.

CRAIK, E. Euripides, Phoenician Women. Commentary. Wiltshirte: Aris \& Phillips LTD, 1988.

DEFORGE, B. Le Festival des Cadavres. Morts et mises à mort dans la tragédie grecque. Paris, Belles Lettres, 1997.

DEPEW, M. Reading Greek Prayers. Classical Antiquity, Vol.16, No.2 (Oct.., 1997), pp.229-258

DETIENNE, M. A Invenção da Mitologia. Brasília, Ed. Unb, 1992.

DEWALD, C. "Myth and Legend in Herodotus' First Book", IN: BARAGWANATH, E., BAKKER, M. Myth, Truth, and Narrative in Herodotus. Oxford, Oxford University Press, 2012.

DOWDEN, K. Os usos da mitologia grega. Campinas: Papirus, 1994.

DREW-BEAR, T. The Trochaic Tetrameter in Greek Tragedy. The American Journal of Philology, Vol. 89, No. 4 (Oct., 1968), pp.385-405. 
EASTERLING, P. "Now and Forever in Greek Drama and Ritual", IN: YATROMANOLAKIS, D., ROILOS, P. Greek Ritual Poetics. Cambridge, Harvard University Press, 2004.

EDMUNDS, L. The Cults and the Legend of Oedipus. Harvard Studies in Classical Philology, Vol. 85 (1981), pp. 221-238.

EDWARDS. R. Kadmos the Phoenician: a Study in Greek Legends and the Mycenaean Age. Amsterdam: Adolf M. Hakkert Publisher, 1979.

FINGLASS, P. "Euripides, "Phoenissae" 1427-8”. Mnemosyne, Fourth Series, Vol. 58, Fasc. 4 (2005), pp. 561-564.

FINLEY, M. I. "Myth, Memory, and History". History and Theory, Vol. 4, No. 3 (1965), pp. 281-302.

FOLEY, H. "Choral Identity in Greek Tragedy", Classical Philology, Vol. 98, No.1 (January, 2003), pp. 1-30.

FONTENROSE, J. Python. A Study of Delphic Myth and its origins. New York, Biblo \& Tannen, 1974.

FOWLER, R. "Early History and Literacy". In: LURAGHI, N. (ed.). The Historian's Craft in the Age of Herodotus. Oxford: Oxford University Press, 2001.

. Herodotus and His Contemporaries. The Journal of Hellenic Studies, Vol. 116 (1996), pp. 62-87.

. "Herodotus and His Prose Predecessors". In: MARINCOLA, J. (ed.). The

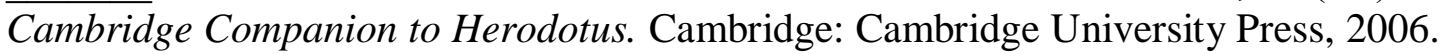

2006b.

. "How to Tell a Myth: Genealogy, Mythology, Mythography", Kernos 19, . "Mythos and Logos”, Journal of Hellenic Studies, 131, (2011), pp.45-66.

FLORY, S. "The Meaning of $\tau \dot{0} \mu \eta \dot{\eta} \mu v \theta \hat{\omega} \delta \varepsilon \varsigma$ (1.22.4) and the Usefulness of Thucydides' History”. The Classical Journal, Vol. 85, No. 3 (Feb. - Mar., 1990), pp. 193-208. 
FRIEDRICH, R. "Everything to Do with Dionysos?", IN: SILK, M. (Ed.) Tragedy and the Tragic. Greek Theatre and Beyond. Oxford, Oxford University Press, 1996.

GIORDANO-ZECHARYA, M. "Ritual Appropriateness in 'Seven Against Thebes', Civic Religion in a Time of War". Mnemosyne, Fourth Series, Vol. 59, Fasc. 1 (2006), pp.53-74.

. "Tragedia greca, religione e riduzionismi. Un bilancio critico a proposito di un nuovo studio di C. Sourvinou-Inwood". Quaderni Urbinati di Cultura Classica, New Series, Vol. 81, No. 3 (2005), pp. 43-59.

GOFF, B. "The Shields of the Phoenissae", GRBS 29 (1988), pp. 135-52. . "The Women of Thebes". The Classical Journal, Vol. 90, No. 4 (Apr. - May, 1995), pp. 353-365.

GOLDHILL, S. "The Great Dionysia and Civic Ideology", The Journal of Hellenic Studies, Vol. 107 (1987), pp.55-76.

. "Civic Ideology and the Problem of Difference: the Politics of Aeschylean Tragedy, Once again. The Journal of Hellenic Studies, Vol.120 (2000), pp.34-56.

GOMME, A. The Legend of Cadmus and the Logographi. The Journal of Hellenic Studies, Vol. 33 (1913), pp. 53-72.

GRAF, F. "Drama and Ritual. Evolution and Convergences". IN: MEDDA, E. Intersezioni del Tragico e del Comico nel Teatro del V Secolo a.C. Pisa, Edizioni Della Normale, 2005.

GREGORY, J. "Euripidean Tragedy", IN: GREGORY, J. A Companion to Greek Tragedy. Malden, Blackwell Publishing, 2005.

GROTEN, F. Herodotus' Use of Variant Versions. Phoenix, Vol. 17, No. 2 (Summer, 1963), pp. 79-87.

HARDING, F. "Local History and Atthidography". in J. Marincola (ed). A Companion to Greek and Romam Historiography. Blackwell Publishing, 2007. 
. The Story of Athens: The Fragments of the Local Chronicles of Attika.

New York: Routledge, 2008.

HARRISON, T. "Religion and the rationality of the Greek city", IN: GOLDHILL, S., OSBORNE, R. Rethinking Revolutions through Ancient Greece. Cambridge, Cambridge University Press, 2006.

HASLAM, M. "Interpolations in the Phoenissae: Papyrus Evidence". The Classical Quarterly, New Series, Vol. 26, No. 1 (1976), pp. 4-10.

HAWES, G. Rationalizing Myth in Antiquity. Oxford, Oxford University Press, 2014.

JACOBY, F. Atthis: The Local Chronicles of Ancient Athens. New Hampshire, 1949.

KIRK, G. Myth, its Meaning \& Functions in Ancient \& Other Cultures. Cambridge, Cambridge University Press, 1970.

KOVACS. D. Euripides. Helen. Phoenician Women. Orestes. Cambridge and London, Harvard University Press, 2002.

Euripidea Tertia. Leiden, Brill, 2003.

. Euripides. Children of Heracles, Hippolytus, Andromache, Hecuba. Cambridge and London, Harvard University Press, 2005.

KOWALZIG, B. “'And now all the world shall dance': Dionysus' Choroi between Drama and Ritual", IN: CSAPO, E., MILLER, M. (eds.) The Origins of Theater in Ancient Greece and Beyond: From Ritual to Drama. Cambridge, Cambridge University Press, 2007.

. Singing for the Gods. Performances of Myth and Ritual in Archaic and Classical Greece. Oxford, Oxford University Press, 2007b.

KÜHR, A. Invading Boeotia. "Polis" and "Ethnos" in the Mirror of Theban Foundation Myths. Hermes, 134. Jahrg., H. 3 (2006), pp. 367-372.

LAMARI, A. Narrative, Intertext, and Space in Euripides Phoenissae. Berlin/New York, Walter de Gruyter GmbH \& Co, 2010. 
LESKY, A. A Tragédia Grega. Trad. J. Guinsburg et alia. São Paulo, Editora Perspectiva, 2003 [1a ed. orig.:1937).

LLOYD, A. Herodotus Book II, Commentary 1-98. Leiden, 1976.

LLOYD, MICHAEL. The Agon in Euripides. Oxford: Clarendon Press, 1992.

LLOYD-JONES, HUGH. The Justice of Zeus. Berkeley, University of California Press, 1983 ( $2^{a}$ edição).

LONSDALE, S. Dance and Ritual Play in Greek Religion. London, The Johns Hopkins University Press, 2000.

MACKOWIAK, K. Les Savoirs de Thalès et de Kadmos. Annales. Histoire, Sciences Sociales, 58e Année, No. 4 (Jul. - Aug., 2003), pp. 859-876

MARINCOLA, J. Authority and Tradition in Anciest Historiography. Cambridge: Cambridge University Press, 1997.

. Greek Historians. Cambridge: Cambridge University Press, 2001.

. "Herodotus and the Poetry of the Past". In: MARINCOLA, J. (ed.). The Cambridge Companion to Herodotus. Cambridge: Cambridge University Press, 2006.

MACKOWIAK, K. Les Savoirs de Thalès et de Kadmos. Annales. Histoire, Sciences Sociales, 58e Année, No. 4 (Jul. - Aug., 2003), pp. 859-876

MARCH, J. The Creative Poet: Studies on the Treatment of Myth in Greek Poetry, BICS Supp. 49, Londres, 1987.

MASTRONARDE, D. Euripides. Phoenissae. Cambridge: Cambridge University Press, 1994.

. The art of Euripides. Dramatic Technique and Social Context. Cambridge: Cambridge University Press, 2010.

. "The Lost Phoenissae: an Experiment in Reconstruction from Fragments". IN: COUSLAND, J. (Ed.) The Play of Texts and Fragments. Leiden, Brill, 2009. 
MASTRONARDE, D., BREMER, J. The Textual Tradition of Euripides' Phoenissae. Berkley: University of California Press, 1982.

MEDDA, ENRICO. Euripide. Le Fenicie. Milão: RCS Libri, 2006.

MCDERMOTT, E. Double Meaning and Mythic Novelty in Euripides'Play. Transactions of the American Philological Association, 121 (1991), pp. 123-132.

MÉRIDIER, L. Euripide. Les Phéniciennes. Les Belles Lettres, Paris, 1950.

MUELLER-GOLDINGEN, C. "Untersuchungen zu den Phönissen des Euripides", Palingenesia 22, Stuttgart, 1985.

MURNAGHAN, S. "The Politics of Tragic Choral Identity", IN: CARTER, D. Why Athens? A Reappraisal of Tragic Politics. Oxford, Oxford University Press, 2011.

MURRAY, O. "Herodotus and Oral History". In: LURAGHI, N. (ed.). The Historian's Craft in the Age of Herodotus. Oxford: Oxford University Press, 2001.

NADDAFF, G. Allegory and the Origins of Philosophy. IN: WIANS, W. (Ed.), Logos and Muthos: Philosophical Essays in Greek Literature. State University of New York Press, 2009.

NICOLAI, R. “"Pater semper incertus'. Appunti su Ecateo". Quaderni Urbinati di Cultura Classica, New Series, Vol. 56, No. 2 (1997), pp. 143-164.

NIETZSCHE, F. O Nascimento da Tragédia ou Helenismo e Pessimismo (trad.: J. Guinsburg). São Paulo, Companhia das Letras, 2008.

OSBORNE, R. Athens and Athenian Democracy. Cambridge, Cambridge University Press, 2010.

PAPADOPOULOU, T. Euripides: Phoenician Women. London, Gerald Duckworth \& Co. Ltd, 2008.

Hermes, 129. Bd., H.1 (2001), pp.21-31. 
PARRY, H. Lines 830-832 of Euripides' "Phoenissae". Phoenix, Vol. 21, No. 1 (Spring, 1967), pp. 20-26.

PODLECKI, A. Some Themes in Euripides' Phoenissae. Transactions and Proceedings of the American Philological Association, Vol. 93 (1962), pp. 355-373.

PRADO, A. História de Guerra do Peloponeso. Livro I. Tucídides. São Paulo: Martins Fontes, 2008.

PULLEYN, S. Prayer in Greek Religion. Oxford, Clarendon Press, 1997.

RAGUSA, G. Lira Grega: Antologia de Poesia Arcaica. São Paulo, Editora Hedra, 2014.

REHM, R. "Ritual in Sophocles", IN: MARKANTONATOS, A. (Ed.) Brill's Companion to Sophocles. Leiden, Brill NV, 2012.

ROY, J. An Alternative Sexual Morality for Classical Athenians. Greece \& Rome, Second Series, Vol. 44, No. 1 (Apr., 1997), pp. 11-22.

SAIID, S. "Herodotus and the 'Myth' of the Trojan War". IN: BARAGWANATH, E., BAKKER, M. Myth, Truth, and Narrative in Herodotus. Oxford, Oxford University Press, 2012.

. "Myth and Historiography". IN: MARINCOLA, J. A Companion to Greek and Roman Historiography. Malden: Blackwell Publishing, 2007.

SALVADOR, E. Tradução da tragédia As Fenícias, de Eurípides, e ensaio sobre o prólogo (vv. 1-201) e o primeiro episódio (vv. 261-637). 2010. Tese (Doutorado em Linguística). Instituto de Estudos da Linguagem. Universidade Estadual de Campinas, Campinas, 2010. Disponível em www.bibliotecadigital.unicamp.br/document/?code $=000785371$. Acesso em 2014-1003.

SAXONHOUSE, A. Another Antigone: The Emergence of the Female Political Actor in Euripides' "Phoenician Women". Political Theory, Vol. 33, No. 4 (Aug., 2005), pp. 472-494.

SCULLION, S. 'Nothing to do with Dionysus': Tragedy Misconceived as Ritual. The Classical Quarterly, New Series, Vol. 52, No.1 (2002), pp. 102-137. 
SEAFORD, R. Dionysiac Drama and the Dionysiac Mysteries. The Classical Quarterly, New Series, Vol. 31, No. 2 (1981), pp. 252-275.

Dionysos. London, Routledge, 2006.

- "Something to Do with Dionysos - Tragedy and the Dionysiac: Response to Friedrich". IN: SILK, M. (Ed.) Tragedy and the Tragic. Greek Theatre and Beyond. Oxford, Oxford University Press, 1996.

SEGAL, C. "Song, Ritual, and Commemoration in Early Greek Poetry and Tragedy", Oral Tradition, 4/3 (1989), pp.330-359.

SOURVINOU-INWOOD, C. Athenian Myths \& Festivals. Oxford, Oxford University Press, 2011.

. "Further Aspects of Polis Religion", IN: BUXTON, R. Oxford Readings in Greek Religion. Oxford, Oxford University Press, 2000.

. "Gendering the Athenian Funeral: Ritual Reality and Tragic Manipulations", IN: YATROMANOLAKIS, D., ROILOS, P. Greek Ritual Poetics. Cambridge, Harvard University Press, 2004.

. "Tragedy and Anthropology", IN: GREGORY, J. A Companion to Greek Tragedy. Malden, Blackwell Publishing, 2005.

Tragedy and Athenian Religion. Oxford, Lexington Books, 2003.

. "What is Polis Religion", IN: BUXTON, R. Oxford Readings in Greek Religion. Oxford, Oxford University Press, 2000b.

STEVENS, P. Euripides and the Athenians. The Journal of Hellenic Studies, Vol. 76 (1956), pp-87-94.

. Colloquial Expressions in Euripides. The Classical Quarterly, Vol. 31, No. 3/4 (Jul. - Oct., 1937), pp. 182-191.

TORRANCE, I. Metapoetry in Euripides. Oxford, Oxford University Press, 2013. 
TORRAnO, J. O Sentido de Zeus: o Mito do Mundo e o Modo Mítico de Ser no Mundo. São Paulo, Iluminuras, 1996.

VELARDI, ROBERTO. Platone. Fedro. Milano: RCS Libri, 2006.

VERNANT, J-P. Mito e Pensamento entre os Gregos (trad. Haiganuch Sarian). São Paulo, Editora da Universidade de São Paulo, 1973.

Mythe et Religion em Grèce Ancienne. Paris, Édition du Seuil, 1990.

- Mito e Tragédia na Grécia Antiga. Trad. Anna Lia A. de Almeida Prado et alia. São Paulo: Ed. Perspectiva, 2008 [1ª ed. orig.:1981].

VERRALL, A.W. Euripides, the Rationalist: A Study in the History of Art and Religion. New York: Russell \& Russell, 1895 (reissued, 1967).

VEYNE, P. Acreditavam os Gregos em seus Mitos? (trad. H. Gonzáles) Brasília, Editora Brasiliense, 1984.

VIAN, F., Les origins de Thèbes. Cadmus et les Spartes. Paris, 1963.

WARDMAN, A. E. Myth in Greek Historiography. Historia: Zeitschrift für Alte Geschichte, Bd. 9, H. 4 (Oct., 1960), pp. 403-413.

WEST. M. The Early Chronology of Attic Tragedy. The Classical Quarterly, New Series, Vol. 39, No. 1 (1989), pp. 251-254.

WEST. S. "Herodotus' Portrait of Hecataeus". The Journal of Hellenic Studies, Vol. 111 (1991), pp. 144-160.

WILSON, P. "How did the Athenian Demes Fund Their Theatre", IN: L'argent dans les Concours du Monde Grec. Paris, Presses Universitaires de Vincennes, 2010.

WINNINGTON-INGRAM, R. A Religious Function of Greek Tragedy: A Study in the Oedipus Coloneus and the Oresteia. The Journal of Hellenic Studies, Vol. 74 (1954), pp.16-24. 
WOODARD, R. (Ed.) The Cambridge Companion to Greek Mythology. Cambridge, Cambridge University Press, 2007.

WRIGHT, M. Euripides' Escape-Tragedies: A Study of Helen, Andromeda, and Iphigenia among the Taurians. Oxford, Oxford University Press, 2005.

.The tragedian as critic: Euripides and early Greek poetics". The Journal of Hellenic Studies, Vol. 130, (November, 2010), pp 165-184.

ZAIDMAN, L., PANTEL, P. Religion in the Ancient Greek City (trad. Paul Carledge), Cambridge, Cambridge University Press, 1992.

ZEITLIN, F. "Thebes: Theater of Self and Society in Athenian Drama". IN: WINKLER, J., ZEITLIN, F. (Eds.) Nothing to Do with Dionysos? Athenian Drama in Its Social Context. Princeton, Princeton University Press, 1992. 